\author{
UNIVERSIDADE DE SÃO PAULO \\ FACULDADE DE FILOSOFIA, LETRAS E CIÊNCIAS HUMANAS \\ DEPARTAMENTO DE LINGUÍSTICA \\ PROGRAMA DE PÓS-GRADUAÇÃO EM SEMIÓTICA E LINGUÍSTICA GERAL
}

\title{
Da intenção ao gesto interpretativo: análise semiótica do canto popular brasileiro \\ Versão corrigida
}

\section{Regina Machado}

Tese apresentada à Área de Semiótica e Linguística Geral do Departamento de Linguística da Faculdade de Filosofia, Letras e Ciências Humanas da Universidade de São Paulo, para obtenção do título de Doutor.

\section{SÃO PAULO \\ 2012}




\section{Regina MACHADO}

\section{Da intenção ao gesto interpretativo: análise semiótica do canto popular brasileiro \\ Versão corrigida}

Tese apresentada à Área de Semiótica e Linguística Geral da Faculdade de Filosofia, Letras e Ciências Humanas da Universidade de São Paulo (USP), para obtenção do título de Doutor em Linguística.

Orientador: Prof. Dr. Luiz Augusto de Moraes Tatit 
FICHA CATALOGRÁFICA

\title{
Dados internacionais de Catalogação na Publicação (CIP) \\ DIVISÃO DE BIBLIOTECA E DOCUMENTAÇÃO ESALQ/USP
}

\author{
Machado, Regina \\ Da intenção ao gesto interpretativo: análise semiótica do canto \\ popular brasileiro \\ -- São Paulo, 2012. \\ $00 \mathrm{p}$. \\ Tese (doutorado) - Faculdade de Filosofia, Letras e Ciências Humanas, 2012. \\ Bibliografia \\ 1. \\ CDD \\ "Permitida a cópia total ou parcial deste documento desde que citada a fonte. - A autora"
}

Título em inglês: From intention to interpretative gesture: semiotics analysis of the Brazilian popular singing

Keywords: popular singing, semiotics, song, Brazilian music, singing voice.

Titulação: Doutorado em Linguística

Área de concentração: Semiótica e Linguística Geral

Banca examinadora:

Prof. Dr. Ivã Carlos Lopes

Profa. Dra. Beatriz Raposo de Medeiros

Prof. Dr. Márcio Luiz Gusmão Coelho

Prof. Dr. José Roberto Zan

Data da defesa: 16 de março de 2012. 


\title{
Banca Examinadora da Tese de Doutorado
}

\author{
Aluna: Regina Machado \\ Orientador: Prof. Dr. Luiz Augusto de Moraes Tatit
}

Membros:

\begin{tabular}{c}
\hline Prof. Dr. \\
\\
\hline Prof. Dr.
\end{tabular}

Prof. Dr.

\begin{tabular}{l} 
Prof. Dr. \\
\\
\hline Prof. Dr.
\end{tabular}

Prof. Dr.

Pós-Graduação em Semiótica e Linguística Geral do Departamento de Linguística da Faculdade de Filosofia, Letras e Ciências Humanas da Universidade de São Paulo

Data: 16 de março de 2012. 
Aos cantores do Brasil, presentes ou não neste trabalho, os verdadeiros conhecedores do sentido emotivo do cantar. 


\section{AGRADECIMENTOS}

Ao meu orientador, Luiz Augusto de Moraes Tatit, pela paciência, pelo cuidado e pela disposição sempre presentes.

Aos professores Beatriz Raposo e Ivã Carlos Lopes, pelos comentários feitos durante a banca de qualificação deste trabalho.

Aos professores Diana Luz Pessoa de Barros, José Roberto do Carmo Jr. e Ivã Carlos Lopes, pelas valiosas aulas, cujos conteúdos aparecem, de um modo ou de outro, neste trabalho.

Aos meus alunos da graduação em Música Popular da Unicamp, que souberam entender a delicadeza do momento vivido durante a elaboração desta tese.

Aos meus colegas do Grupo de Estudos de Canto Popular, do Canto do Brasil, pelas discussões sempre enriquecedoras sobre a canção e o comportamento vocal. 
À amiga Tereza Lourenço, pelo trabalho realizado, que foi muito além da simples revisão desta tese, contribuindo de maneira sensível para a qualidade da pesquisa.

\begin{abstract}
À Silvia Regina Ferreira, pelo afeto, pela presença sempre constante e pelo amplo apoio, que me possibilitaram dedicar horas à realização deste trabalho enquanto a vida real continuava seguindo seu curso.
\end{abstract}

Aos alunos, amigos e funcionários do Canto do Brasil Atividade e Ensino Musical, que também me apoiaram nesta realização.

Aos amigos e parceiros de jornada musical, Italo Peron e Norberto Vinhas, pelas conversas, pelos trabalhos e pelas realizações musicais sempre prazerosas.

Aos meus padrinhos Dyonisio e Sylvia, pelo apoio sempre incondicional às minhas escolhas e realizações.

À minha mãe, Margarida, às minhas irmãs, Rita e Rosana, ao meu cunhado Jorge e, especialmente, ao meu sobrinho Guilherme.

Agradeço especialmente aos Profs. Drs. Beatriz Raposo, Ivã Carlos Lopes, José Roberto Zan e Márcio Coelho pelos valiosos comentários realizados durante a defesa desta tese. 


\section{EPÍGRAFE}

"Todo conhecimento é um reconhecimento - algo que a tragédia nos havia prevenido, quer esse reconhecimento se dê na desgraça ou na alegria. Diremos, apenas de passagem, que todo pensamento em seu curso retoma a cadeia das pressuposições que o ordena, livra-se das propostas que se revelaram não-indispensáveis e esse reconhecimento é, além do mais - ou, talvez, acima de tudo-, como que uma fonte de juventude, pois que ele corresponde, enfim! a um acesso ao que já estava lá todo o tempo e, de certo modo - assim como em A Carta Roubada de Poe- escondido porque ofertado." 


\section{RESUMO}

A canção popular brasileira, principal produto da nossa cultura midiática, vem obtendo reconhecimento nos meios acadêmicos nesses últimos anos, justificando o desenvolvimento de uma prática descritiva que se dedica a analisá-la: a Semiótica da Canção, desenvolvida por Luiz Tatit. Curiosamente, no entanto, o canto popular, principal veículo de manifestação dessa canção, só agora começa a despertar o interesse de pesquisadores. Este trabalho pretende, partindo da aplicação da Semiótica da Canção e a ela acrescentando uma terminologia adequada à percepção descritiva do comportamento vocal, analisar algumas das principais vozes do Brasil, com base na escuta de fonogramas. Procuramos, assim, traduzir o que denominamos Qualidade Emotiva das vozes, na tentativa de desenvolver uma descrição analítica que superasse o juízo de valor ou a mera adjetivação.

Palavras-chave: canto popular, semiótica, canção, música brasileira, voz cantada. 


\section{ABSTRACT}

During the last years, Brazilian popular song, which are the main product of our media culture, is obtaining recognition among the academic environment, justifying the development of a descriptive practice that is dedicated to analyze it: The Song Semiotics developed by Luiz Tatit. However, it wasn't until now, that popular singing, which is the main means of these songs manifestation, started to awake researchers interest. Starting on The Song Semiotics and adding to it an appropriate term for the descriptive perception of the vocal behavior, this work intend to analyze some of the main Brazilian voices, based on phonograms listening. We will try this way to express what we call Voices Emotive Quality, in an effort to develop an analytic description that overcomes any judgment or mere qualification.

Key Words: popular singing, semiotics, song, Brazilian music, singing voice. 


\section{SUMÁRIO}

RESUMO

ABSTRACT $\quad x$

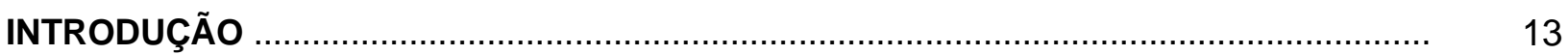

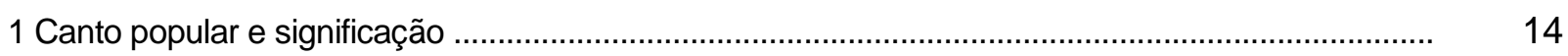

1 A VOZ NA CANÇÃO POPULAR BRASILEIRA URBANA …........................................ 19

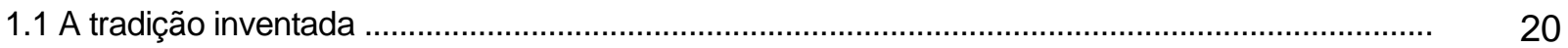

1.2 As vozes da canção popular brasileira urbana ..................................................................... 22

1.3 A intuição e a intelecção no canto popular do Brasil ................................................................. 36

\section{A SEMIÓTICA DA CANÇÃO E SUA APLICAÇÃO NA ANÁLISE DO} COMPORTAMENTO DA VOZ CANTADA

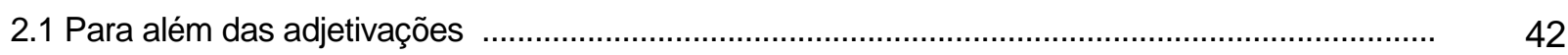

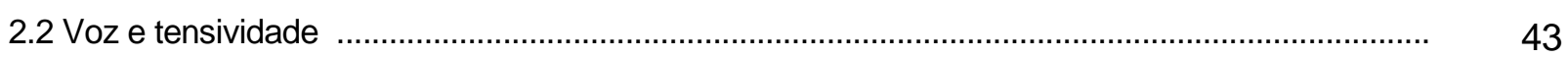

2.2.1 Passionalização, tematização e figurativização …................................................. 46

2.3 Níveis da voz: elementos de fisiologia e técnica vocal ............................................................ 48

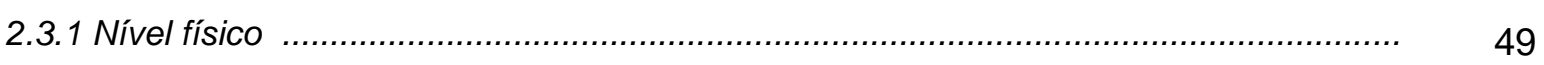

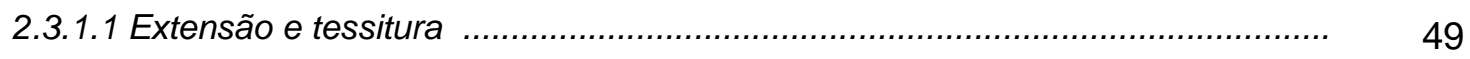

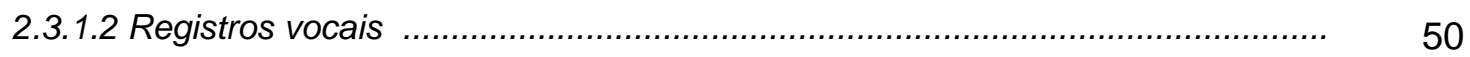

2.3.1.3 Timbre e significação ....................................................................... 51

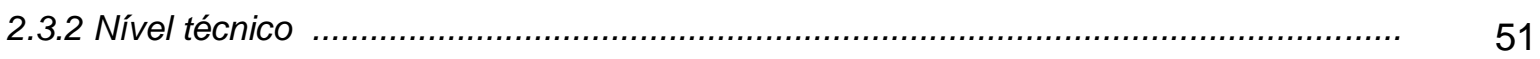

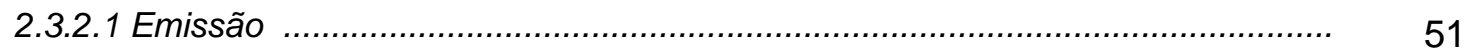

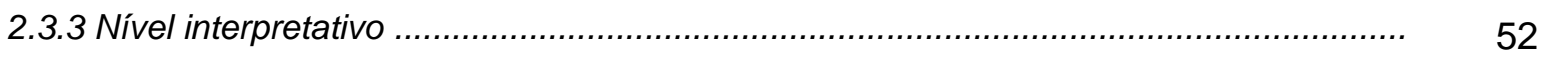

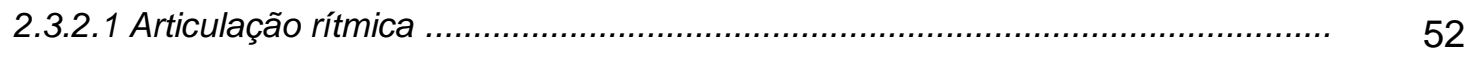

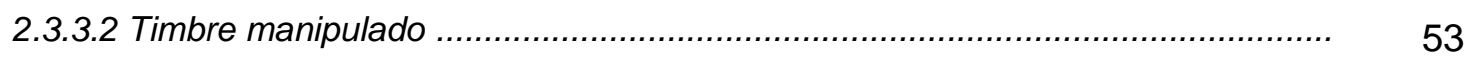

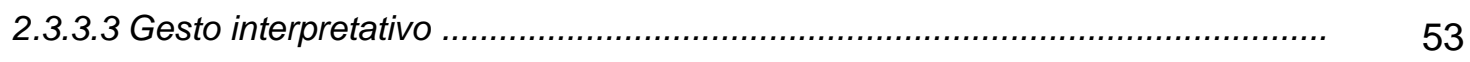

3 A ESCOLHA DAS CANÇÕES E A METODOLOGIA DAS ANÁLISES ............................ 55

3.1 A escolha das canções ............................................................................................... 56

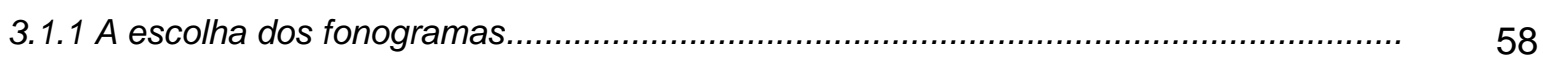

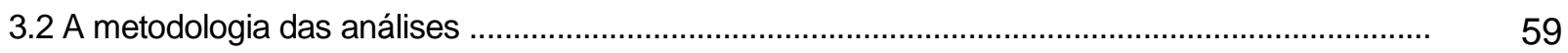

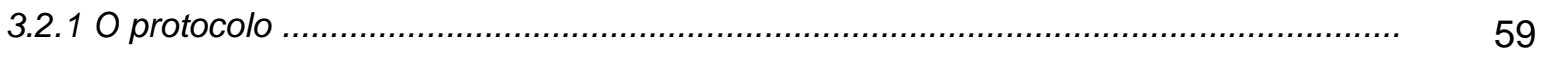

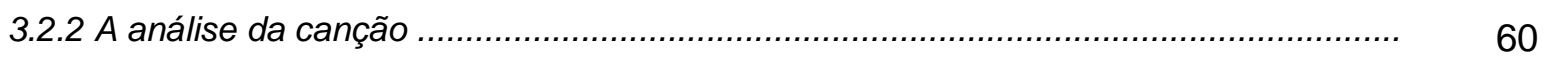

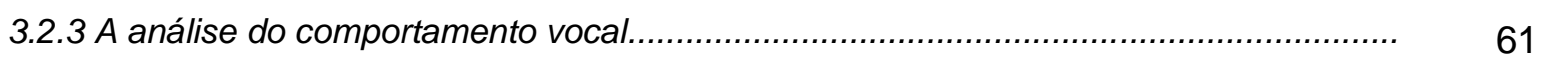




\section{AS ANÁLISES}

4.1 Ave Maria no Morro (Herivelto Martins)

Dalva de Oliveira (1942)

João Gilberto (1991)

4.2 Beatriz (Edu Lobo e Chico Buarque de Holanda) ....................................................................... 75

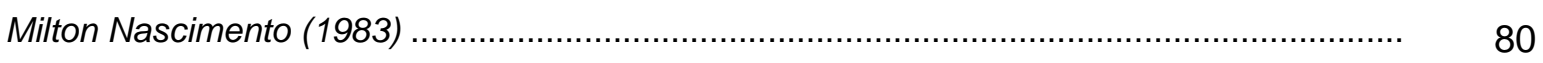

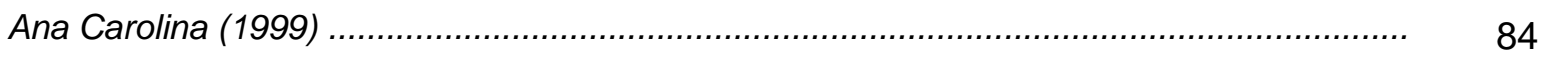

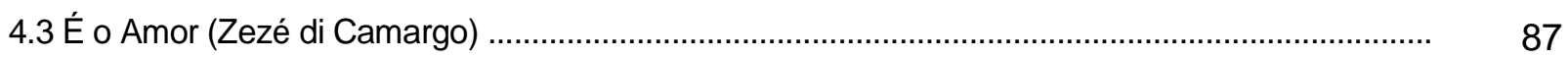

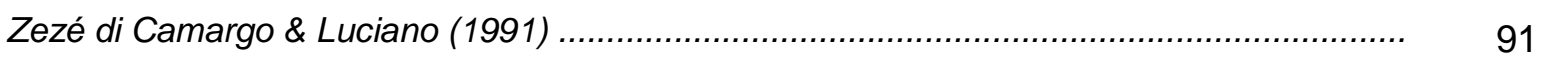

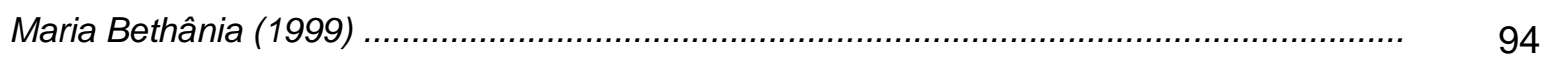

4.4 Falsa Baiana (Geraldo Pereira) …….................................................................................. 97

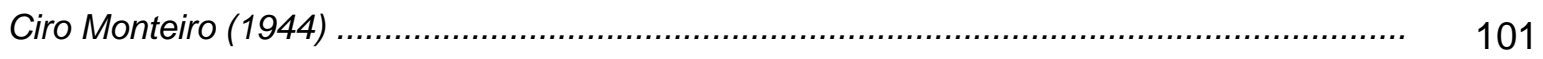

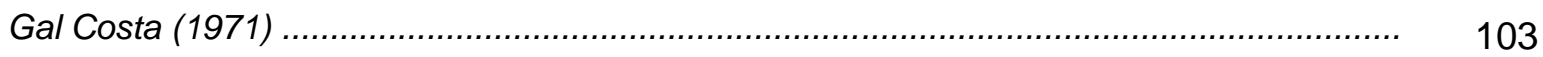

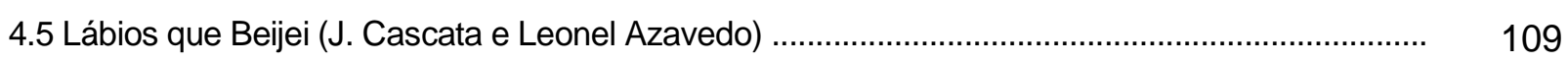

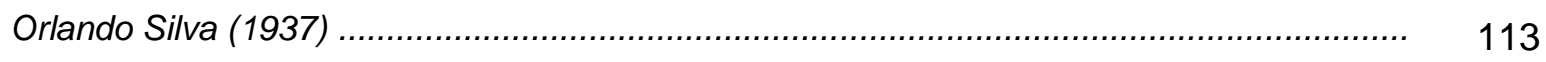

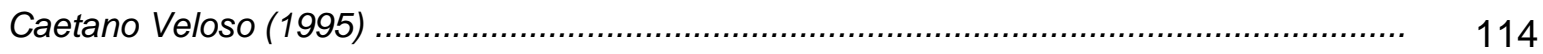

4.6 Linda Flor - Yayá (Henrique Vogeler, Marques Porto e Luiz Peixoto) ........................................ 117

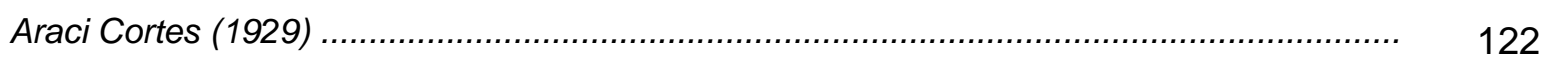

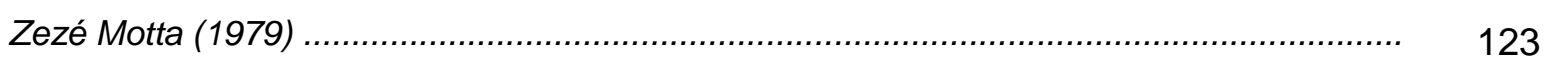

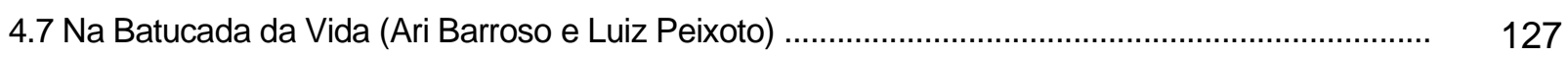

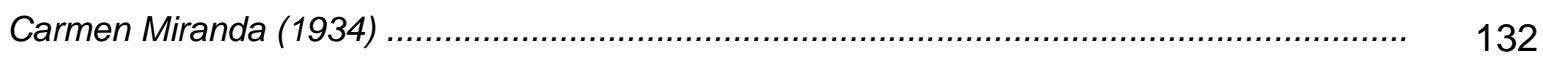

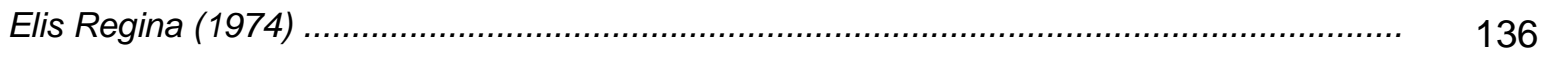

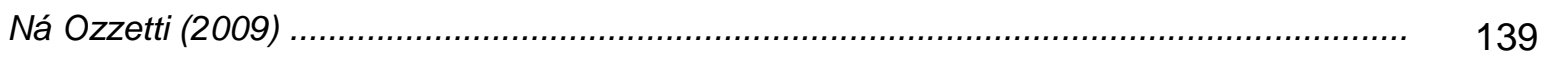

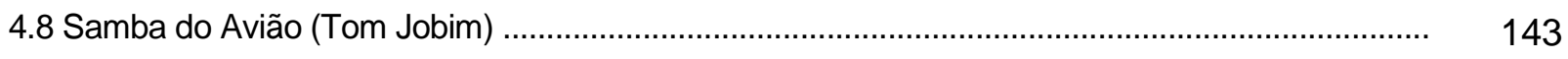

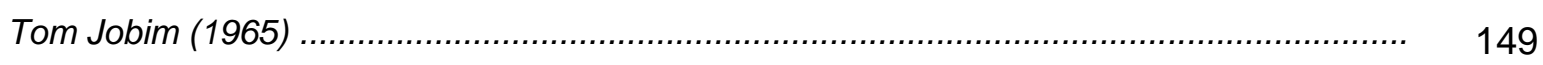

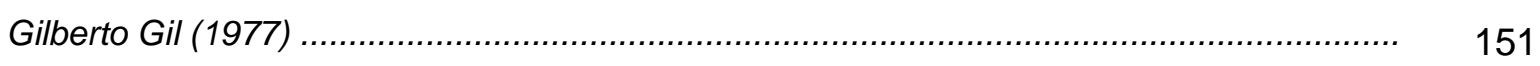

5 GESTO VOCAL E SIGNIFICAÇÃO - UM INVENTÁRIO DAS VOZES ANALISADAS ....... 155

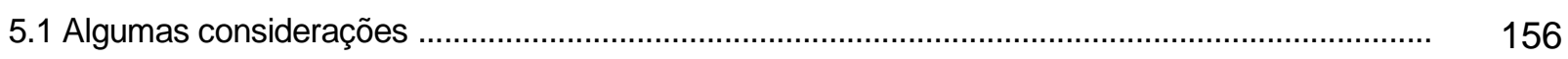

5.1.1 Passionalização, tematização e figurativização vocais ............................................. 158

5.1.2 Tensividade e construção de sentidos pela voz ................................................. 161

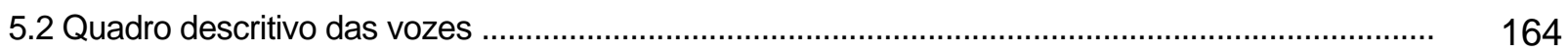

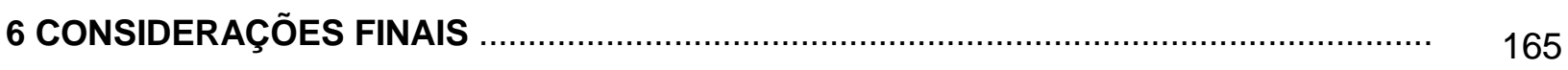

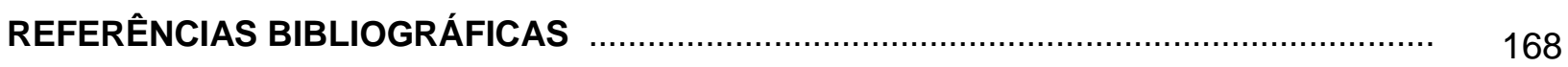

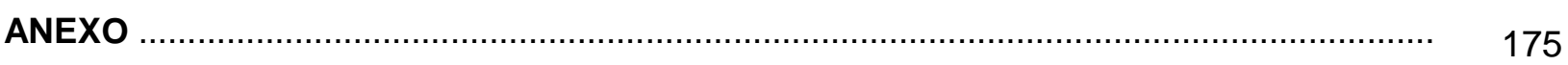

Anexo 1: Discos contendo as faixas analisadas ...................................................................... 176 
INTRODUÇÃO 


\section{CANTO POPULAR E SIGNIFICAÇÃO}

No Brasil, a importância da canção popular começa a ser reconhecida nos meios acadêmicos, justificando a presença de um número já significativo de trabalhos desenvolvidos nesta área.

A longa história escrita pelos compositores e intérpretes mostra-se, ano após ano, capaz de se manter viva e em constante renovação, atingindo sempre um número expressivo de pessoas, fato bastante raro em outras manifestações artísticas brasileiras, exceção talvez feita à telenovela.

A elaboração da Teoria Semiótica da Canção por Luiz Tatit é, até agora, a mais expressiva comprovação do reconhecimento dos meios acadêmicos à importância dessa manifestação. Assim, a fundação de uma prática descritiva que pudesse atender às demandas dos pesquisadores, no sentido de compreender mais profundamente as articulações engendradas na composição, vem satisfazer a expectativa de muitos que desejam tratar de maneira mais minuciosa esse assunto.

Contraditoriamente, se a canção popular já alcançou relevância para se tornar assunto de teses e dissertações, o canto popular, principal veículo dessa realização, só agora começa a ganhar alguns poucos estudos, entre os quais se inclui este trabalho que apresentamos.

Durante anos, o canto popular no Brasil foi tratado nos meios de produção como uma manifestação de talento puro, na qual não se admitia a interferência de processos racionais que pudessem descaracterizá-lo.

Como refere Tatit (1995) sobre o compositor popular, dizendo que ninguém sabe exatamente quando nem como surgiu sua habilidade para realizar canções, da 
mesma forma o cantor popular seria fruto exclusivo do talento e do acaso, dotado naturalmente de uma capacidade especial de, com sua voz, emocionar a audiência.

Sem negar esse fato, visto que, com efeito, o talento de muitos intérpretes revelou-se de maneira absolutamente espontânea, consideramos necessário encontrar um instrumento de análise que pudesse observar a realização vocal considerando a técnica do canto, ainda que adquirida pelo exercício da profissão e não pelo desenvolvimento de um estudo formal, mas reconhecendo a intencionalidade emocional como geradora dessa competência.

Ao entrarmos em contato com a Semiótica da Canção, enxergamos a possibilidade de tratar a questão sobre o Gesto Interpretativo de maneira a revelar significados que extrapolassem a mera adjetivação ou que incorressem em juízo de valor. Assim, vislumbramos ser possível realizar uma descrição técnica apoiada por uma elucidação de sentido que pudesse resultar numa prática descritiva complementar à Semiótica da Canção, no sentido de acrescentar a esta as categorias e as referências técnicas específicas do canto.

Iniciamos a pesquisa de repertório considerando um recorte amplo sobre a chamada MPB, que hoje engloba a obra de compositores e intérpretes variados, indo de Chico Buarque e Edu Lobo a Zezé di Camargo e Luciano, passando de Gal Costa a Ana Carolina. Intencionalmente, destacamos agora os nomes nesta ordem, para tornar claro que hoje o termo MPB é utilizado de modo amplo, dispondo-se a identificar os diversos atores da canção. Atualmente, não é mais possível compreender essa terminologia como referência específica a uma produção comprometida com certo tipo de engajamento político ou mesmo com uma única referência estética cancional.

Com o intuito de demonstrar o papel decisivo do intérprete na realização, escolhemos duas gravações de cada canção, feitas em épocas diferentes por 
cantores cujas carreiras tiveram (ou têm) uma grande representatividade no universo da música popular, demonstrando que nem sempre os processos de estandartização da música midiatizada impediram o surgimento de expressões diferenciadas no campo do canto e da canção popular. Desta forma, pudemos percorrer, ao longo das análises, um número considerável de composições e gestos vocais diferenciados que se tornaram referência para a música popular brasileira, extrapolando, e muito, o fato de terem sido criadas e registradas no eixo Rio-São Paulo, recorte que norteou a pesquisa de repertório e a escolha de fonogramas.

No Capítulo 1 - "A voz na canção popular brasileira urbana" -, procuramos descrever uma trajetória das vozes na canção midiatizada, seguindo a ideia da constituição de uma genealogia que consolidou no Brasil, ao longo do século $X X$, uma sólida tradição vocal. Por essa linha de raciocínio, foi possível identificar as principais vozes da canção popular e a maneira como cada uma produziu influências nas gerações seguintes, fazendo ouvir o passado no presente e, a partir daí, lançar matrizes para um futuro do canto popular.

No Capítulo 2 - "A semiótica da canção e sua aplicação na análise do comportamento vocal" -, partindo da inquietação manifestada por pensadores como Paul Zumthor e Roland Barthes, procuramos explicar de que maneira a Semiótica da Canção desenvolvida por Luiz Tatit, na qualidade de prática descritiva, poderia explicar o comportamento vocal de modo a revelar os sentidos inscritos no gesto interpretativo. Ao lidar com elementos tais como a emissão (timbre), o andamento, a tessitura, a articulação rítmica e a entoação, por exemplo, passamos a fazê-lo não mais exclusivamente por um viés técnico, como seria recorrente numa abordagem sobre canto, mas buscando compreender como esses recursos seriam utilizados, no plano local ou global, para expressar os estados fóricos e os estados juntivos inscritos na composição. 
No Capítulo 3 - "A escolha das canções e a metodologia das análises" -, detivemo-nos em explicar os critérios para a escolha das canções e dos fonogramas que seriam analisados. Além disso, procuramos detalhar, progressivamente, como se daria o processo de construção das análises e a metodologia adotada.

No Capítulo 4 - "As análises" - encontra-se o corpus do presente trabalho. Nessas análises, como já foi dito, buscamos demonstrar a intenção por trás do gesto interpretativo. Sendo assim, procuramos tornar possível observar a existência de uma inteligência emocional norteando a ação dos intérpretes.

A partir daí, tornou-se possível, no Capítulo 5 - "Gesto vocal e significação: um inventário das vozes analisadas" -, organizar uma descrição sistemática dos comportamentos vocais detectados nas análises, demonstrando não apenas os traços de particularização delineados por cada intérprete, mas também como cada um desses elementos atuou na constituição daquilo que denominamos Qualidade Emotiva.

Chegamos, então, à elaboração de um quadro descritivo, no qual são referidos os componentes tensivos do canto de cada intérprete. Nesse quadro, elencamos o campo global como aquele em que se articulam o Andamento e a Emissão, enquanto no plano local estariam a Articulação Rítmica e o Vibrato. Quanto à Entoação, outra subcategoria elencada, entendemos que ela poderia refletir uma ação local, isolada, que desta forma não se refletiria na totalidade da interpretação, ou, ainda, poderia configurar uma ação vocal duradoura, produzindo efeito de sentido no plano global da interpretação.

A percepção e a compreensão dos gestos presentes em cada subcategoria levaram à constituição daquilo que denominamos Qualidade Emotiva e que pretende identificar na voz os elementos da passionalização, da tematização ou da figurativização. Concluímos, por fim, que essas características se faziam presentes nas vozes de maneira complementar, o que nos levou a elaboração de seis 
categorias diferentes: Passional, Passional Figurativizada, Passional Tematizada, Tematizada, Tematizada Figurativizada, Tematizada Passional.

Pretendemos, assim, dar início à estruturação de um processo analítico que possa traduzir a intenção por trás do comportamento técnico, musical e interpretativo, desenvolvendo uma terminologia que revele, mesmo que parcialmente, o componente emotivo presente no canto. 
A VOZ NA CANÇÃO POPULAR
BRASILEIRA URBANA 


\subsection{A TRADIÇÃO INVENTADA}

"Nós somos apenas vozes

Nós somos apenas nós

Por exemplo, Apenas vozes da voz

Somos nós, por exemplo

Apenas vozes da voz." (GILBERTO GIL, Nós, por exemplo)

A canção popular brasileira urbana, como produto de uma sociedade de consumo e destinada ao entretenimento, nasce no início do século passado, com a implantação dos meios de gravação fonomecânicos. Ali começam a ser documentadas maneiras de cantar e de compor que se consolidariam ao longo do século $X X$. No que tange ao canto, duas tendências estéticas diferenciadas seriam passíveis de observação desde aquele momento: uma ligada à tradição do belcanto ${ }^{1} \mathrm{e}$, por consequência, à cultura branca das elites, e outra resultante do modo de falar do povo nas ruas, possivelmente em virtude da presença negra e indígena na sociedade miscigenada que então se consolidava.

Ao longo de nossa história, essas duas maneiras de cantar continuariam presentes, ainda que a primeira, ou seja, aquela ligada à tradição do belcanto, passasse a ser denominada, principalmente após a Bossa Nova, de estilo antigo. Cada vez mais ganharia espaço o estilo vocal que equilibrava a fala e o canto, evidenciando-se, esta estabilização, como o principal elemento da atitude vocal na canção popular brasileira.

Embora muito se tenha dito sobre a passagem de um canto "operístico" para um canto mais coloquial a partir da implantação das gravações elétricas (1927), é possível observar que, desde os primeiros registros realizados pela Casa Edison (com os cantores Baiano, Cadete e Eduardo das Neves, por exemplo), já predominava uma estética vocal baseada na fala. De fato, nesse modo de cantar a utilização de vibrato não é perceptível à

\footnotetext{
1 "A arte do canto de tradição operística italiana dos séculos XVII e XVIII, que enfatiza pureza e homogeneidade de notas, agilidade e precisão da técnica vocal" (HOUAISS, 2001).
} 
escuta, e a emissão apresenta-se bastante aberta, de modo diverso das referências vocais ligadas ao belcanto e que estão claramente presentes em gravações de outros cantores da mesma época, como Vicente Celestino e outros seguidores de uma tradição que, no Brasil, se consolidou por meio da seresta ${ }^{2}$.

Embora o sistema de gravação mecânico exigisse potência vocal do cantor caso contrário o sulco não se fincava no disco de cera e, portanto, o registro não acontecia -, vemos que os cantores citados, Baiano, Cadete e Eduardo das Neves, utilizavam o volume sem, no entanto, alterar o tipo de emissão vocal, que tinha na fala sua principal referência sonora e estilística.

Desta forma, parece-nos que ao longo do século XX a atitude vocal na canção popular brasileira, partindo dessas duas abordagens sonoras diferenciadas, seguiu mantendo a primeira tendência praticamente inalterada, mas levando a segunda abordagem a experimentos cada vez mais radicais, seja com a atitude adotada na Bossa Nova, seja sobretudo com o canto que se desenvolveu durante a Vanguarda Paulista.

Com base nessa percepção - de que as tendências da voz na canção popular urbana brasileira, partindo de um comportamento matricial, oferecem fontes tanto para a conservação quanto para mudança de padrão estético -, é também possível afirmar que a consolidação de uma tradição no modo de cantar foi sendo transmitida de geração a geração pela prática da escuta e, até certo ponto, da imitação.

Foi dessa maneira que muitas gerações de cantores populares, até o início dos anos 1990, aprenderam seu ofício. E sempre movidos pelo desejo de consolidar sua própria marca interpretativa, além de se espelhar em seus ídolos, cada cantor buscou transformar esse canto imprimindo algum detalhe de sua marca pessoal.

Essa genealogia da voz é facilmente percebida por meio de estudos de relatos dos próprios cantores, que revelam em depoimentos recorrentes as vozes que foram referência para sua formação e mesmo aquelas que imitavam no início de suas carreiras. Por exemplo, é o caso de Elis Regina com relação à Ângela Maria, de Gal Costa com

\footnotetext{
2 "Gênero de canção sentimental trazida de Portugal no início do século XVIII cujo nome foi criado no Rio de Janeiro na tradição da serenata" (DOURADO, 2004).

${ }^{3}$ Termo empregado por Júlio Diniz em "Sentimental demais: a voz como rasura", in Do samba-canção à tropicália (2003, p. 99).
} 
relação à Dalva de Oliveira e a João Gilberto, de Marisa Monte com relação à Gal Costa, de Roberto Carlos com relação a João Gilberto e Orlando Silva, de Maria Bethânia com relação à Dalva de Oliveira, isto para ficar em alguns poucos e notórios exemplos.

Outro dado importante a ser apontado na formação do cantor popular é o fato de que, durante anos, e mesmo ainda nos dias de hoje, o culto ao talento inato sempre foi reforçado. Temia-se que a interferência de um estudo vocal formal pudesse destruir um aspecto sublime que sempre se estabeleceu como uma aura geradora e protetora das grandes vozes.

Desta forma, essa tradição foi se inventando e reinventando ao longo do século XX, consolidando uma estética vocal para a nossa canção urbana e possibilitando que os cantores desenvolvessem, ainda que intuitivamente, um caminho de aprimoramento técnico e interpretativo ligado à tradição oral, à escuta e à percepção, e não ao estudo formal.

Talvez ainda pelo mesmo motivo tenhamos levado tanto tempo até iniciar uma metodologia de estudo da voz cantada específica para a canção popular, baseada em sua própria tradição sonora, fato esse que só ocorreu no Brasil no início dos anos 1990 e provocou uma mudança significativa, produzindo, a partir daí, uma geração de cantores populares com formação técnica e musical, como é o caso da cantora Mônica Salmaso, por exemplo.

\subsection{AS VOZES DA CANÇÃO POPULAR BRASILEIRA URBANA}

Partindo da periodização estabelecida por Zuza Homem de Mello e Jairo Severiano em seu livro $A$ canção no tempo (1998), aceitamos que a canção popular pode ser dividida em seis grandes momentos. Descrevem os autores no volume $1 \mathrm{da}$ referida obra um momento inicial, de 1901 a 1916, que preambula o surgimento das gravações fonográficas para, em seguida, entrar naquele que seria um segundo período, de 1917 a 1928. Destacam ainda um terceiro período, de 1929 a 1945, e, finalmente, um quarto, de 1946 a 1957, antecessor da primeira grande revolução musical, que foi a Bossa Nova. 
De acordo com os autores, é no segundo momento que ocorrem o surgimento e a consolidação do samba. A data inaugural seria o ano de 1917, com a gravação de "Pelo Telefone", ${ }^{4}$ de Donga e Mauro de Almeida, feita pelo cantor Baiano para a Casa Edison. O gênero sofreria uma mudança significativa a partir do final da década de 1920 - com o samba produzido pelos compositores do Estácio de Sá (SANDRONI, 2001, p. 131), como Bide e Marçal - e atingiria o ápice por volta de 1945. Todo esse período, conhecido como Época de Ouro, teria então dado origem à matriz da música popular brasileira produzida no eixo Rio-São Paulo, já que as referências deixadas por seus compositores e cantores influenciariam de modo significativo as gerações seguintes até o final dos anos 1980 .

É nesse momento que surgem e se consolidam as vozes-modelo da nossa canção, cabendo destacar os cantores que já se revelavam, então, como luzeiros do caminho que começava a ser delineado e percorrido. São eles: Francisco Alves, Araci Cortes, Carmen Miranda, Araci de Almeida, Mário Reis, Luiz Barbosa e Orlando Silva.

Francisco Alves e Orlando Silva - associados efetivamente a um comportamento vocal referenciado na seresta - ligam-se também ao universo musical do samba, atenuando em suas vozes o uso de vibrato, embora ainda mantendo a predominância da voz cantada sobre a falada, exaltando o componente musical de seus fraseados melódicos. É importante destacar que Orlando Silva, ainda muito jovem, tinha uma noção claríssima de dinâmica musical, fraseado rítmico, afinação, revelando uma consciência técnica que possivelmente se desenvolveu pela percepção musical e desejo de expressão interpretativa, visto que o cantor nunca estudou canto de modo formal.

Araci Cortes era atriz do teatro de revista e pode ser considerada a matriarca da voz na canção popular brasileira, dado que foi a primeira mulher a se consolidar profissionalmente como cantora. Sua emissão vocal dava-se, pelo menos nos anos iniciais de sua carreira, em região muito aguda da voz; no entanto, ela produzia uma grande variedade de padrões vocais, ora acentuando a presença da voz cantada e a utilização de vibratos, ora trazendo para o primeiro plano as finalizações entoativas que

\footnotetext{
${ }^{4}$ Registrado como o primeiro samba gravado da história da música popular brasileira, cuja autoria é discutida até hoje, visto que nasceu nas rodas de partido alto que aconteciam na casa de Tia Ceata, no Rio de Janeiro.
} 
enfatizavam a presença da fala. Influenciou diretamente a cantora Carmen Miranda, fato observável em suas primeiras gravações, que junto com Mário Reis e Luiz Barbosa tornaram-se as principais referências da época para a elucidação da "voz que fala na voz que canta", fazendo da entonação ${ }^{5}$ o principal veículo da construção de sentidos para a voz cantada.

Cabe destacar também que Carmen Miranda, em razão de sua inserção no cinema norte-americano a partir dos anos 1940 - fato que projetou mundialmente sua imagem e também uma vertente da música brasileira -, irá consolidar a performance cênica atrelada à expressão vocal. Anos mais tarde, aquela atitude artística seria referência para a criação cênica dos artistas ligados à Tropicália.

Entre 1946 e 1957, o samba-canção (antes conhecido como "samba de meio de ano", já que não era produzido para o Carnaval e tratava predominantemente da temática da perda amorosa) sofreria algumas modificações significativas do ponto de vista musical, pois as harmonias se sofisticariam com os acréscimos de tensões aos acordes. Isso, de certa maneira, pode-se reconhecer como início das mudanças que se aprofundariam na Bossa Nova a partir de 1958. Naquele período, ocorreria nas vozes, tanto femininas quanto masculinas, um rebaixamento das tessituras, resultando numa aproximação da fala, que expressava por meio dessas canções um forte conteúdo passional. É nesse momento que, até certo ponto, a voz abre mão do atributo da potência da emissão para dar vazão à expressão dramática, traduzindo também no plano da expressão, ou seja, no seu componente sonoro, os conteúdos dos textos musicais e linguísticos. No entanto, mantêm-se ainda a utilização acentuada de vibrato e os prolongamentos de finais de frases como componentes de uma força expressiva, embora já fosse possível notar fraseados nos quais o padrão entoativo se pronunciasse com mais ênfase, como, por exemplo, em interpretações das cantoras Nora Ney e Dolores Duran, e também em gravações do cantor Lúcio Alves.

É importante observar que esse tipo de abordagem vocal que revela um componente de intimidade não era comum até então, mesmo nas canções cujo conteúdo poético predominante era a perda amorosa. Ao acrescentar à expressão vocal

\footnotetext{
5 "Modulação na emissão de uma sentença, que indica se se trata de uma afirmação, pergunta, pedido ou ordem, ou se o falante está contente, surpreso etc" (HOUAISS, 2001).
} 
um componente intimista, o intérprete aproximava o ouvinte da narrativa, e este poderia sentir-se, então, protagonista do drama apresentado.

Essa música e suas vozes vão povoar as noites de cidades como São Paulo e Rio de Janeiro, possibilitando que os bares e as boates se tornassem o espaço físico público da expressão da dor amorosa, como bem ilustra a letra da canção "Bar da Noite" (Bidu Reis/Haroldo Barbosa): "bar tristonho, sindicato de sócios da mesma dor/ bar que é o refúgio barato dos fracassados do amor". Era a época da chamada "música de fossa", que exigia dos cantores um discurso vocal mais denso e íntimo. A cantora Nora Ney destaca-se no período, sobretudo por uma característica física, pois sua voz, extremamente grave, mostrava-se natural e adequada para essa expressão dramática, além do que ela construirá, em sua expressão vocal, um gesto que faz uso de padrões entoativos que equilibram canto e fala.

As duas tendências vocais apontadas no início deste trabalho continuam surgindo concomitantemente nesse período da canção. Assim, temos os cantores que, mesmo com os conteúdos passionalizados das músicas, fazem uso de um canto mais entoativo (falado) como a já citada Nora Ney, Lúcio Alves, Dick Farney e Dolores Duran, além de outros, como Elizeth Cardoso, Ângela Maria e Cauby Peixoto. Eles continuam a tradição de um canto em que o atributo musical das vozes é explorado ao máximo na construção de uma expressão dramática. Os três começaram a cantar ainda na infância, Ângela e Cauby nos coros das igrejas que frequentavam com as famílias e Elizeth no rancho Kananga do Japão.

Vale ressaltar aqui que Ângela Maria, em sua primeira gravação da música "Babalu", em 1958, fazia uso diferenciado da voz, que alternava entre registros e emissões, demonstrando que a canção popular comportaria uma voz carregada de inovações e comportamentos diferentes daqueles já estandartizados pela indústria fonográfica. No entanto, a cantora abandonou as atitudes portadoras de uma nova significação vocal em prol de uma conduta identificada com as canções românticas que privilegiavam a potência e a dramaticidade, características que a consagraram desde a gravação de "Não Tenho Você", em 1951. 
Também nessa fase imediatamente anterior à Bossa Nova são marcantes as presenças de Dolores Duran e Maysa, por serem as primeiras mulheres a se afirmarem no mercado musical da época como compositoras. Além disso, Dolores Duran se destaca como uma cantora capaz de transitar por gêneros musicais absolutamente diversos, indo do jazz ao baião com uma flexibilidade vocal raramente vista na música brasileira até então. A serviço das canções, mais até que da própria personalidade, Dolores moldava diferentes timbragens à sua voz, para fazê-la atuar como um veículo de expressão do sentido inscrito na composição.

Em 1958 e 1959, respectivamente, chegam ao mercado os LPs Canção do amor demais e Chega de saudade. O primeiro reunia canções da então desconhecida dupla de compositores Antonio Carlos Jobim e Vinicius de Moraes, na voz da consagrada Elizeth Cardoso. Já o segundo trazia o cantor e violonista João Gilberto, que, naquele trabalho, apontava a grande revolução que se iniciaria no comportamento vocal dentro do universo da canção popular brasileira. Colocando voz e violão no mesmo nível no que se refere ao plano de gravação e mixagem, o cantor desnudava a voz de qualquer recurso artificialista, aproximando-a da fala. Exigia de si próprio um grande rigor técnico no sentido de precisão na emissão das notas, que não usufruíam do recurso do vibrato, por exemplo, como elemento dissimulador de uma instabilidade na afinação.

Embora alguns componentes desse tipo de comportamento vocal já fossem detectados em cantores de épocas anteriores - como os já citados Luiz Barbosa, Mário Reis e Carmen Miranda, representantes da chamada Época de Ouro da música brasileira -, a grande novidade, além da relação rítmica que irá se estabelecer entre voz e violão, reside no fato de que João Gilberto levou esse tipo de abordagem vocal também para o universo das canções passionais, como a própria "Chega de Saudade", sem, no entanto, desfigurar seus valores emotivos. Dessa maneira, abriam-se, naquele momento, novas possibilidades para a voz, tanto no campo do plano da expressão, no que se refere ao seu material sonoro, quanto no plano do conteúdo, ou seja, das significações que se construíam com aquele cantar. Essa atitude vocal não apenas revelava novas nuances expressivas para a voz, como também destruía o mito dos 
chamados "vozeirões", abrindo possibilidades para outros tipos de intérpretes que começariam a surgir a partir da Bossa Nova.

Com a entrada nos anos 1960, graças às transformações vocais ocorridas durante a Bossa Nova, muitos compositores tornam-se intérpretes de sua própria obra, trazendo o componente da dicção autoral para esse canto desprovido, no início, de um componente vocal de destaque. Surgem também como cantores Chico Buarque, Edu Lobo, Jorge Ben e Geraldo Vandré, entre outros.

O universo da canção popular passa a viver uma fase de grande ebulição criativa e diversidade musical, cuja divulgação ocorre pelo veículo mais expressivo da época: a televisão. É nesse período que se observará uma grande variedade de comportamentos e estéticas vocais que, mais do que nunca, tornarão as vozes e os intérpretes portadores de um componente ideológico. A transmissão da imagem redimensionará a atitude dos cantores, que passarão a ser, mais que uma voz, um corpo que se expressa e constrói significações.

Podemos apontar três vertentes produtivas nesse período, distribuídas entre os nichos dos Festivais, da Jovem Guarda e da Tropicália. Em cada uma dessas vertentes é possível observar os comportamentos vocais que se tornaram refletores das ideologias subjacentes aos diversos grupos. Por exemplo, embora os Festivais fossem um espaço natural para a diversidade musical e vocal, a consagração do gênero música de protesto dominou a imagem que se lançou depois sobre esse ambiente. Sendo assim, essa chamada $\mathrm{MPB}^{6}$ que discutia os direitos civis por meio da canção popular fixa o espaço do Festival como seu principal ponto de permanência.

As vozes identificadas com esse gênero musical - cuja revolução política não propunha necessariamente transformações estéticas do produto artístico - são aquelas que se apresentam na região média da tessitura, fato que confere veracidade à fonte sonora, por se aproximarem da sobriedade na referência falada. Ao mesmo tempo, conseguem impactar o ouvinte pela conclamação à reflexão e ação coletivas. Sendo assim, a atitude vocal dos cantores que melhor representaram o gênero repercutia imediatamente no âmbito do público, que reconhecia na simplicidade, na

\footnotetext{
${ }^{6}$ Ver NAPOLITANo, M. Seguindo a canção: engajamento político e indústria cultural na MPB (1959-1969). São Paulo: Annablume/Fapesp, 2001.
} 
objetividade e na carga emotiva do intérprete um convite à participação ativa, como se se tratasse de um coro em uníssono.

Não cabia nesse espaço de identificação atitudes vocais que buscassem romper os padrões estéticos da época, pois, de certa forma, um fator de inovação impossibilitaria a participação coletiva. Ou seja, embora o espaço do Festival permitisse a presença de comportamentos vocais de vanguarda, as atitudes vocais imediatamente reconhecidas pelo público é que ganhavam notoriedade e eco popular. Por esta via consagram-se os intérpretes Jair Rodrigues e Marília Medalha, bem como os compositores/cantores Edu Lobo, Geraldo Vandré, Caetano Veloso e Gilberto Gil, entre outros.

Sobre a necessidade da expressão vocal não apresentar comportamentos inusitados, Caetano Veloso nos parece um excelente exemplo, daquele momento, a ilustrar essa questão. Embora "Alegria, Alegria" fosse um ícone pré-tropicalista no que se refere à canção - com sua letra cheia de imagens aparentemente desconexas, como numa colagem, e seu arranjo comprometido com a força dos versos -, a maneira de cantar do intérprete mantinha-se conectada à tradição da Bossa Nova, sem nenhuma proposta de ruptura com um canto popular reconhecível. Esse fator contribuiu para atenuar os elementos pouco compreensíveis da letra, chamando o público para o refrão que naquele momento também ganhava uma conotação política - "Por que não? Por que não?" -, conclamando a plateia a discutir os comportamentos padronizados e as imposições tanto da direita conservadora como da esquerda revolucionária.

É exatamente nesse instante que se dá o principal embate entre aqueles compositores e intérpretes ligados a uma atuação política dentro da música popular e os chamados tropicalistas. Os primeiros preconizavam a revolução social e política por meio exclusivo do conteúdo das obras, enquanto os segundos pretendiam uma ruptura estética no âmbito da criação da letra e da concepção sonora dos arranjos das canções, o que se estenderia para além da composição, penetrando no universo do canto e da performance cênica.

A Jovem Guarda, por sua vez, vai expressar os anseios da porção da sociedade considerada alienada dos debates políticos do período. Trazendo para o universo da canção brasileira elementos do rock anglo-americano, o movimento provocará 
transformações significativas não só no canto, mas nas composições e na instrumentação, mostrando certa irreverência como traço básico da juventude dos anos 1960, mas sem esconder suas boas relações com a ideologia do consumo já totalmente implantada nos Estados Unidos.

Essa produção musical dirigida a um público específico encontrará na figura erigida por Roberto Carlos seu ícone máximo. Tendo como referências vocais iniciais João Gilberto e Orlando Silva, Roberto Carlos irá conjugar duas imagens aparentemente opostas, seja no aspecto da performance cênica, seja no comportamento vocal. Ele será um dos primeiros a introduzir na voz certo grau de estridência do rock, alternando-se entre esse gesto e uma expressão vocal mais contida, ligada à canção romântica, como é possível constatar ao ouvirmos as gravações de "É Proibido Fumar" e "Canzone per Te".

Com o advento do Tropicalismo, podemos considerar que ocorreu a síntese das transformações dos anos 1960. Assumir o Brasil em todas as suas facetas implicava, paradoxalmente, rompimentos de toda natureza, até mesmo com a noção de estética vigente à época. A Tropicália resgata algumas das propostas apresentadas pelos modernistas na Semana de Arte Moderna de 1922 e traz, para o universo da canção popular, elementos da vanguarda que irão atingir as composições, o cantar e a performance cênico-interpretativa dos artistas. Todos esses elementos associados levarão, para o âmbito da canção popular, uma atitude de profunda reflexão crítica e intelectual, como é possível notar na obra de seus principais intérpretes e compositores: Tom Zé, Caetano Veloso e Gilberto Gil.

A cantora Gal Costa torna-se a principal representante dessa expressão vocal aliada à ideia de transformação estética, migrando de uma atitude completamente bossa-novista - presente em seu disco de estreia, dividido com Caetano Veloso, intitulado Domingo - para uma atitude radicalizada no campo da estridência vocal, como é possível notar em sua interpretação de "Divino Maravilhoso", cuja expressão máxima acontecerá no disco gravado ao vivo durante o show Fa-Tal (Gal a todo vapor), de 1971, com direção de Wally Salomão. 
Ainda sobre as mudanças vocais ocorridas na canção brasileira nos anos 1960, pode-se afirmar que foi nessa década que surgiram as três principais referências vocais femininas, que se tornariam matrizes para as vozes das gerações seguintes até os dias de hoje: a já citada Gal Costa, Maria Bethânia e Elis Regina. A primeira, como já vimos, ligada às ideias do movimento tropicalista, irá explorar e trazer para o universo da canção popular recursos como o grito presente no rock. Maria Bethânia, que inicialmente cria uma imagem de artista politizada pelo trabalho que realizou no espetáculo Opinião, consolidará no canto popular um lugar especial para a voz grave, de expressão direta e articulação rítmica capaz de particularizar suas interpretações, porque totalmente baseada na valorização expressiva da palavra e na construção de um fraseado rítmico dramatizado. Ao longo de sua carreira, Bethânia deixará cada vez mais clara a presença da fala teatralizada como elemento norteador de seu canto e consagrará a criação de uma dramaturgia para a realização do espetáculo musical. Seus shows, mais do que apresentar uma sequência de canções, viriam sempre estruturados por uma narrativa subjacente que orientava a construção do roteiro e para a qual estavam voltados todos os elementos, dos arranjos à iluminação, dos figurinos à direção. Elis Regina, por fim, fará uso de todos os recursos vocais possíveis para que sua expressividade, bastante passional, possa se projetar sobre a canção.

Todas essas cantoras fizeram uso constante da performance como elemento complementar da interpretação. Indiscutivelmente, a cada uma dessas vozes está associada uma imagem muito marcante, que pode ter sofrido alterações ao longo de suas carreiras, mas que sempre foi um elemento fundamental na construção interpretativa. Definitivamente, a partir de então a voz se tornou também um corpo em cena.

Ainda no final dessa mesma década surgiria o cantor Milton Nascimento, cuja voz resgatava uma aura de divinização, tanto no nível físico, pelos atributos naturais do timbre e da potência, quanto no interpretativo, pela carga expressiva. Ele será o primeiro a trazer para o universo da canção popular no Brasil a utilização da voz como instrumento, que apresentará mais uma dimensão da possibilidade interpretativa, conferindo sentido à expressão sonora. Embora apareça como intérprete e compositor no ambiente dos Festivais, será durante os anos 1970 - com trabalhos como Clube da Esquina, Milagre dos Peixes, Minas e Geraes -, que Milton revelará novas 
possibilidades para a voz no universo da canção popular, libertando-a de formas e convenções que o mercado tanto insiste em impor aos cantores.

Entre o final dos anos 1960 e o início dos 1970, surgem três outras cantoras também modelares, embora não façam parte de nosso atual objeto de estudo: Clara Nunes, Beth Carvalho e Alcione. É nesse momento que o samba volta a conquistar um espaço na mídia e nos meios de produção fonográfica, com o ressurgimento dos compositores Cartola e Nelson Cavaquinho, além do aparecimento de figuras que se tornariam fundamentais para a música popular brasileira, tais como Elton Medeiros, Paulinho da Viola, Hermínio Bello de Carvalho e Clementina de Jesus (cantora sobre a qual seria possível dedicar um estudo, dada a peculiaridade de seu gesto vocal, além de sua performance cênica).

Como pudemos observar até aqui, os anos 1960 são importantíssimos para o desenvolvimento da voz na canção popular. As referências ali surgidas figuram até hoje como modelos para a nossa produção artística, só tendo ocorrido novas ideias para o uso da voz nesse ambiente musical durante a chamada Vanguarda Paulista, sobre a qual falaremos mais à frente.

A década de 1970 foi, predominantemente, dos compositores/cantores: Paulinho da Viola, surgido no final dos anos 1960 no movimento de resgate do samba, Tim Maia, João Bosco, Gonzaguinha, Luiz Melodia, Ivan Lins e Djavan. Intérpretes de suas obras, com marcas vocais particularizadas, mas avançando pouco na obra de outros compositores (exceção talvez feita a Paulinho da Viola), eles tornaram sua atitude vocal muito presa à dicção autoral, fato que não ocorreu com os compositores Caetano Veloso e Gilberto Gil, por exemplo, que construíram um gesto interpretativo vocal ampliado.

Pudemos observar, ainda, que o espaço aberto pela Bossa Nova para que os compositores fossem também intérpretes de sua própria obra possibilitou uma grande expansão nessa área e praticamente paralisou o surgimento de intérpretes masculinos. A não ser pelo aparecimento do grupo Secos e Molhados - que trazia Ney Matogrosso como um intérprete que inaugurava na canção popular a presença de uma voz pouco comum, denominada contratenor no âmbito da música erudita -, aquela teria sido, para 
as vozes masculinas, uma década exclusiva dos compositores/cantores. Mas a voz agudíssima de Ney, que à primeira escuta deixava dúvidas quanto ao sexo do cantor, seguiu a tendência tropicalista de ruptura e ainda se viu acrescida do visual andrógeno e extremamente ousado assumido por um artista que propunha, no mínimo, uma nova revolução de costumes no universo da música de consumo.

Em 1974, após deixar o grupo, Ney Matogrosso manteve em seu trabalho-solo o mesmo tipo de proposta cênica, sendo possível detectar em seu componente vocal uma forte conexão com o samba-canção dos anos 1950, sobretudo com o componente dramático de vozes como as de Ângela Maria e Cauby Peixoto. Sobre as mudanças comportamentais que de certa maneira teriam iniciado na década anterior, com os Tropicalistas e as cantoras Gal Costa e Maria Bethânia, o trabalho de Ney acrescentava agora um componente vigoroso, que abalava a estrutura moral de uma sociedade conservadora e vigiada por uma ditadura militar no seu período de maior fechamento político.

Quanto às vozes femininas na canção popular, parece que o impacto produzido pelo surgimento da trindade Elis/Bethânia/Gal gerou um emudecimento que só seria parcialmente rompido no final dos anos 1970 e início dos 1980, com o aparecimento das cantoras, e por vezes compositoras, Joyce, Angela RoRo, Marina Lima, Joanna, Simone, Zizi Possi, Elba Ramalho, Fátima Guedes, Fafá de Belém e, um pouco mais tarde, Leila Pinheiro. Embora algumas delas reabrissem as possibilidades de presença feminina no universo autoral - espaço que havia deixado de ser frequentado pelas mulheres desde Dolores Duran e Maysa, no final dos anos 50 -, do ponto de vista vocal, à exceção de Marina Lima, Fátima Guedes e Elba Ramalho, sobre as quais falaremos a seguir, nenhuma delas se apresentou como inauguradora de uma nova vertente para a voz na canção brasileira, seguindo ainda os mesmos passos vocais inaugurados por Elis, Gal e Bethânia.

Sobre Elba Ramalho, é possível afirmar que ela trouxe para o universo da canção popular urbana uma característica vocal diferenciada, cujo componente principal seria a tradição nordestina das carpideiras. Essas mulheres, de vozes muito agudas, cantadoras típicas das cerimônias fúnebres do Nordeste, marcam presença na genealogia vocal de Elba, conferindo ao seu timbre um componente metalizado e um 
tipo de vibrato rápido, que se manifesta não apenas na região aguda da voz, mas por toda a sua extensão, particularizando de modo significativo o seu cantar. No entanto, olhando para os anos subsequentes, parece que essa peculiaridade vocal não teve continuidade, ao menos no universo da canção midiatizada.

Da mesma maneira, a cantora e compositora Fátima Guedes apresentava um componente vocal bastante diferenciado, que percorria uma grande extensão vocal, com um timbre que evidenciava os harmônicos agudos, conferindo um corpo estreito à voz, a qual produzia na escuta uma sensação de agudização. Suas canções, sempre tendendo à passionalização, estabeleciam um certo contraste entre a fragilidade da voz e a contundência das composições, chamando a atenção para o trabalho da intérprete.

Já com respeito à Marina Lima, cuja expressão vocal mesclava elementos da fala a uma abordagem pop, pode-se considerar que ela tenha levado sua dição autoral também para o universo interpretativo, tornando-se, por sua conduta vocal e performance cênica, modelo para a geração de Cássia Eller e Zélia Duncan, por exemplo.

Ainda nos anos 1980, o surgimento da Vanguarda Paulista, como ficou conhecida mais tarde, injetaria novos elementos transformadores no comportamento vocal dentro do universo da canção popular. Primeiro, em decorrência da obra dos próprios compositores, como Arrigo Barnabé, Luiz Tatit e Itamar Assumpção; depois, pela singularidade das vozes e da gestualidade vocal da também compositora Tetê Espíndola, assim como de Vânia Bastos, Neusa Pinheiro, Suzana Salles e, sobretudo, Ná Ozzetti. Por se tratar de um núcleo de acontecimentos musicais que ficou à margem da grande mídia, somente hoje, cerca de trinta anos depois, é que essa produção musical ganhou alguma notoriedade, tendo já produzido uma nova geração de compositores e intérpretes que sofreram influência direta de suas realizações, como Tulipa Ruiz, Yara Rennó e Andrea Dias, por exemplo.

No final dos anos 1980, mais precisamente em 1988, o lançamento do primeiro disco solo da cantora Ná Ozzetti, até então integrante do Grupo Rumo, voltaria a radicalizar o comportamento vocal na canção popular brasileira, depois de um hiato de vinte anos. Levando para seu trabalho solo toda a experiência adquirida no grupo, Ná Ozzetti enfatizou a presença da fala no canto, experimentou alterações microtonais no 
padrão de afinação, fazendo uso de todas as suas habilidades vocais e interpretativas para fazer a canção falar e expor todos os componentes resultantes desse enlace entre melodia e letra. Dona de uma personalidade cênica bastante introvertida, Ná esteve (e está) sempre a serviço da canção, fazendo de sua voz a continuadora de uma tradição e, ao mesmo tempo, inauguradora de uma nova vertente que explora comedidamente o espaço cênico, radicaliza na construção do gesto interpretativo, criando um novo espaço sensível com essa oposição performance cênica/performance vocal.

É interessante notar que o acontecimento mais inovador para a voz na canção desse período tenha ocorrido à margem dos grandes veículos de comunicação e, por consequência, do acesso ao grande público. Diferentemente do que se observou nos anos 1960, quando todos os acontecimentos musicais estavam ocupando os principais espaços da televisão, a partir da década de 1980 a padronização que assolou os meios de comunicação tornou praticamente inexistente o espaço para a música popular, sobretudo para a música que propunha transformações, quer no campo autoral, quer nos aspectos interpretativos e performáticos.

Em 1990, Marisa Monte reinou absoluta. Herdeira da tradição vocal inaugurada por Gal Costa, Marisa trouxe para o universo das cantoras a habilidade de produtora e gerenciadora de sua própria carreira. Com um disco inaugural que mostrava sua versatilidade como cantora, tornou aquilo que todas já faziam uma marca particularizada. O ecletismo no repertório, que sempre foi uma característica de Dolores Duran, Elis Regina e Gal Costa, entre outras, sem nunca ter sido anunciado como um diferencial - pois afinal, não o era -, tornou-se um selo de garantia do cantar de Marisa Monte. Todos os intérpretes, a menos que estivessem vinculados exclusivamente a um universo musical (como, por exemplo, as já citadas Clara Nunes, Alcione e Beth Carvalho), faziam uso de uma ampla gama de variedade musical em seus repertórios. No entanto, quando do lançamento do primeiro LP de Marisa Monte, Marisa Monte, a marca da publicidade anunciava esse mesmo ecletismo como sua característica principal e diferenciadora. A mídia comprou e veiculou essa ideia como uma grande inovação, tornando a cantora, de talento indiscutível, o grande acontecimento midiático dos anos 1990. 
Em meados dessa mesma década, mais três cantoras/compositoras viriam dividir o mercado com Marisa: Zélia Duncan, Cássia Eller e Adriana Calcanhoto. As duas primeiras seguidoras, como já dito, de uma tradição mais ligada ao pop rock, lançariam matrizes para o predomínio de vozes graves com um componente masculino que se traduzia também na performance cênica.

Surgida no final da década de 1990, é importante destacar a presença da cantora Mônica Salmaso, que construiu sua carreira longe dos grandes veículos de mídia, mas desfrutando de grande respeitabilidade no meio musical. De certa forma, podemos dizer que ela resgatou a tradição de cantores como Milton Nascimento, fazendo da voz um instrumento não apenas das palavras, mas sobretudo da música. Também é possível detectar em sua descendência musical a presença de Nana Caymmi, sobre quem falaremos mais à frente, como modelo no que concerne ao timbre e mesmo a uma melancolia subjacente que parece orientar toda a emotividade do canto de Mônica. No entanto, a intérprete conduziu sua expressividade por meio da busca do equilíbrio na realização dos fraseados musicais, utilizando o componente timbrístico natural como um importante elemento na complementação dessa mesma expressividade, mas priorizando a música como elemento vital da canção.

E o que dizer das vozes masculinas desde Ney Matogrosso? Em trinta anos não surgiram novos cantores? Podemos citar, na esteira da proposta de Ney, o cantor Edson Cordeiro e, no seguimento de uma tradição miltondjavaniana, o cantor Renato Brás.

De certa forma, o mercado fonográfico parece lidar permanentemente com elementos paradoxais: embora insista em padronizar, a premissa da inovação seria cada vez mais indispensável para a projeção em um ambiente saturado e ao mesmo tempo carente de novas propostas tanto vocais quanto musicais.

Por fim, rompendo a cronologia para ressaltar a particularidade da voz, destaque-se a presença vocal de Dorival Caymmi. Surgido também como intérprete nos anos 1930, num momento em que não era comum a presença dos compositores à frente dos microfones, Caymmi possuía uma voz muito peculiar, de timbre escuro e denso, capaz de se estender pelo tempo ou mesmo de realizar recortes rítmicos particulares. De certa forma, seu canto se tornou uma espécie de significante sonoro da Bahia, pois sua voz se notabilizou ao narrar as histórias de mar, que deram origem a um gênero denominado canções praieiras e àquelas que descrevem personagens típicos da terra ("O que é que a baiana tem", "A preta 
do acarajé", "Acontece que eu sou baiano", "A lenda do Abaeté", etc.). Muitas dessas características vocais estão presentes nas vozes de seus filhos, Dori, Danilo e Nana, intérprete cuja marca vocal é a intensidade dramática que se expressa não apenas pelo timbre, mas também pela particularidade de seus fraseados e articulação rítmica. Assim, as vozes cayminianas constituem uma genealogia dentro da genealogia.

Neste breve percurso da voz no século da canção, tentamos deixar claro o processo de invenção de uma tradição que se deu no âmbito do canto popular urbano, mostrando que essa dinâmica está viva, não cessa de se transformar e produzir frutos. A manutenção de uma tradição depende da presença de seus seguidores, o que torna perfeitamente compreensível que transformações radicais no campo do canto popular, e mesmo da composição, ocorram em grandes intervalos de tempo, pois, caso contrário, seria quase impossível permanecer uma nova referência vocal. Esse fato revela a importância da presença de tantos intérpretes e, sem dúvida, destaca aqueles que mais raramente apontam novos caminhos e permitem que, por influência de seus gênios criadores, surjam tantos seguidores que se torne possível estabilizar uma nova tradição, até que outra proposta de ruptura se apresente.

\subsection{A INTUIÇÃO E A INTELECÇÃO NO CANTO POPULAR DO BRASIL}

“(...) tudo o que a razão possui passou primeiro pelos sentidos, não sendo a razão, em sentido amplo, algo simples ou primário, senão o fruto do entrosamento de todas as demais faculdades do homem, que se processa numa passagem das idéias simples às idéias complexas, isto é, da razão sensitiva ou pueril à razão intelectual ou humana."

(J.-J, ROUSSEAU, Ensaio sobre a origem das línguas)

Embora a intervenção da razão esteja presente em toda ação humana, no canto popular a habitual mitificação dos cantores acabou por inibir, durante anos, todo tipo de reflexão ou mesmo toda proposta de descrição dos procedimentos vocais adotados por muitos intérpretes ao longo desses quase cem anos da indústria fonográfica. No entanto, 
se apenas com João Gilberto, no final dos anos 1950, é que se viu um artista assumindo a manipulação de sua voz na construção de uma intenção interpretativa, esse tipo de manipulação já era observável, em graus diferentes, desde Araci Cortes e, pouco depois, em Mário Reis, Luiz Barbosa e Carmen Miranda. Para os cantores que trabalhavam suas vozes apenas pelo viés do padrão de beleza vocal, a naturalidade do gesto, de certa maneira, impedia a presença viva de uma atitude mental sobre a construção de uma significação, embora, mesmo assim, ela estivesse presente. No entanto, em cantores como os que mencionamos, a conexão com a língua falada e a expressão dessa sonoridade no canto demandavam uma interferência produzida pelo desejo expressivo de ir além da condição natural do timbre. Esses intérpretes fizeram uso de entoações faladas que produziram efeito de sentido no campo rítmico-melódico e expandiram o gesto interpretativo para além da beleza natural da voz.

Voltando a João Gilberto, podemos considerar que ele foi o primeiro a tornar pública sua obstinação pelo acabamento da realização vocal/instrumental. Aquilo que sempre foi visto como uma excentricidade do artista - por exemplo, o fato de se recolher durante dois anos longe do Rio de Janeiro para reformular o seu canto ${ }^{7}$-, na verdade revela uma disciplina e uma preocupação com o acabamento na execução, posturas pouco adotadas no âmbito da música popular. Revela também o sentimento de desconforto do artista ante a atitude vocal da época em que inicia sua carreira, bem como o desejo de transformação dessa estética mediante um árduo exercício vocal articulado com a prática violonística.

Eu estava então [década de 50] muito descontente com aqueles vibratos dos cantores - Mariiiina moreeeena Mariiiina você se pintoooou - e achava que não era nada disso. (...) Sentia que aquele prolongamento de som que os cantores davam prejudicava o balanço natural da música. Encurtando o som das frases, a letra cabia certa dentro dos compassos e ficava flutuando. Eu podia mexer com toda a estrutura da música, sem precisar alterar nada. Outra coisa com que eu não concordava era as mudanças que os cantores faziam em algumas palavras, fazendo o acento do ritmo cair em cima delas para criar um balanço maior. Eu acho que as palavras devem ser pronunciadas da forma mais natural possível, como se estivesse conversando. (João Gilberto apud GARCIA, 1999, p. 127-128)

\footnotetext{
${ }^{7}$ Esse e outros fatos ligados à mítica de João Gilberto fazem parte da narrativa expressa em Chega de saudade: a história e as histórias da bossa nova (Ruy Castro, 2008).
} 
Esse depoimento nos mostra que João Gilberto foi movido inicialmente por uma percepção de incompatibilidade entre o que a canção dizia e a maneira como estava sendo cantada. Ele não reconhecia naquela maneira de cantar uma expressão adequada aos conteúdos da canção, mas sim uma sobreposição da personalidade do cantor à obra. Desta maneira, passou a elaborar o seu canto refazendo esse caminho, na busca de expressar pela voz (e pelo violão) os conteúdos inscritos na canção. Esse novo gesto vocal, delineado com base em uma inquietação estética, repercutiu de maneira significativa entre seus contemporâneos e, com mais ênfase, na geração imediatamente posterior.

Já é de praxe considerar que esse espírito investigativo de João Gilberto influenciou intensamente seus sucessores, como é o caso dos tropicalistas, que reconhecem no baiano um agente transformador de seus olhares sobre a canção popular.

Partiremos dos próprios compositores Caetano Veloso, Tom Zé e Gilberto Gil, além de Gal Costa e dos Mutantes, que passam a reconhecer no canto um instrumento de expressão não apenas de beleza, mas agora sobretudo de significação. Vislumbram, a partir daí, utilizar a voz para que, sonoramente, ela faça sentido e se compatibilize com os textos, tanto musicais quanto linguísticos.

O disco Panis et Circensis, lançado em 1968 pelo grupo tropicalista, é talvez o mais radical exemplo de uma utilização intencional de padrões vocais diferenciados para produzir sentido não somente em cada uma das canções, mas no disco como um todo. As músicas não se sucedem como peças isoladas, e sim como etapas de um mesmo projeto, que se faz notar em cada uma das faixas, seja na composição, seja nos arranjos ou nos efeitos sonoros, reportando-se a uma espécie de narrativa subjacente. Mesclam-se, nesse trabalho, comportamentos vocais que se vinculam à tradição com outros que a abandonam totalmente, como podemos ouvir em "Parque Industrial", composição de Tom Zé. As vozes de Gilberto Gil, Gal Costa e Caetano Veloso se sucedem de maneira clara e, até mesmo, previsível. Porém, esse equilíbrio é rompido pela entrada da voz de Tom Zé, que adota um timbre metálico/nasal, com ênfase nos Rs rolados, imprimindo um tom crítico e um humor sarcástico ao cantar: "a revista moralista traz uma lista dos pecados da vedete/ e tem jornal popular/ que nunca se espreme porque pode derramar". 
Da mesma maneira, as intervenções vocais dos Mutantes em outras canções, como a própria "Panis et Circensis", produzem um efeito de estranhamento que atua como elemento de atração para o ouvinte, visto que as vozes adotam modos de emissão que resultam em timbragens pouco comuns ao universo da canção popular da época. De certa forma, as inovações vocais presentes nesse trabalho, bem como os arranjos que thes dão sustentação instrumental, causam estranhamento até hoje, como pudemos observar a cada nova utilização desse material em aula. ${ }^{8}$

O desfolhar dessa bandeira, parafraseando a letra de Torquato Neto, imprimirá no pensamento desses intérpretes novas atitudes vocais, que se tornarão complementares não apenas às suas composições, mas também às muitas releituras de canções consagradas, inaugurando uma nova maneira de olhar o nosso passado musical, em todas as suas fases. É a partir desse momento que os cantores incluirão em seus trabalhos, com certa frequência, as chamadas releituras de canções, muitas das quais com significativa alteração no campo do andamento, justamente para exporem suas competências interpretativas.

Os discos de Gal Costa lançados nos anos seguintes - Gal (1969), Fa-tal (1971) trazem um material riquíssimo do ponto de vista do canto. A cantora mescla o gesto vocal bossanovista com a estridência tropicalista, adotando procedimentos vocais que se compatibilizam com as canções e ampliam o campo de significação da obra gravada. Isto porque a percepção do significado passa a existir não apenas na relação melodia/letra, mas sobretudo na presença do componente vocal, que traduz esse eixo central com gestos diversos e que extrapola a natureza pura da voz. Em vários aspectos, podemos considerar que os tropicalistas abriram os caminhos que anos mais tarde seriam percorridos e ampliados pela geração da Vanguarda Paulista.

Com Arrigo Barnabé, Itamar Assumpção, Luiz Tatit, Ná Ozzetti, Tetê Espíndola e Suzana Salles, a ação do intelecto sobre a interpretação ganhará dimensões ainda mais profundas, visto que as ações vocais sobre as questões timbrísticas, por exemplo, serão exploradas de maneira mais intensa, propondo novos elos de ligação estética para a canção popular. Além disso, podemos destacar as inserções de quase fala e mesmo as variações microtonais de entoação, como é possível observar na versão de

\footnotetext{
${ }^{8} \mathrm{Na}$ disciplina que ministro no curso de Música Popular da Unicamp, é sempre notório o impacto que o disco Panis et Circenses provoca na plateia de alunos. Tanto esse material quanto os trabalhos da vanguarda paulista ainda são bastante desconhecidos das novas gerações e produzem um grande impacto.
} 
"Sua Estupidez" (Roberto e Erasmo Carlos), realizada pela cantora Ná Ozzetti em seu disco de estreia (1988) fora do Grupo Rumo, ou ainda a versão de "Mulata Assanhada", realizada por Itamar Assumpção em seu disco Pra sempre agora, no qual interpreta somente canções de Ataulfo Alves.

Talvez o ponto mais importante desta ação intelectual por trás da emissão vocal resida no fato de que essas mudanças surgiram, na maioria das vezes, não como fruto de um exercício vazio da inovação pela inovação, mas sim pelo desejo de construir uma interpretação que fizesse a diferença; e de produzir uma voz que elucidasse elementos por vezes ocultos à primeira vista, ainda que já inscritos na canção, atingindo afetivamente o ouvinte e abrindo novas possibilidades de escuta no universo cancional midiatizado.

Também pelo viés das inovações, é possível detectar uma linha de descendência na canção brasileira de consumo. Podemos considerar que os cantores Mário Reis, Luiz Barbosa e Carmen Miranda foram verdadeiros paradigmas para João Gilberto, cantor que redefiniu todo seu gesto vocal no sentido de valorizar aspectos minimais do canto. De certa forma, podemos dizer que João Gilberto intensificou esses aspectos de quase fala, já presentes na geração da Época de Ouro, somando a isso a afinação precisa, uma articulação rítmica que destaca o componente sonoro da palavra, relacionando o canto com a levada do violão, numa interação entre gesto rítmico e harmônico. Essa realização impactou profundamente a geração seguinte, na qual surgiram Roberto Carlos, Caetano Veloso, Gilberto Gil, Tom Zé e Gal Costa, entre outros.

O grupo tropicalista, por sua vez, somou a essa dicção joãogillbertiana a estridência do rock que invadia as cabeças da juventude dos anos 60 , bem como os conteúdos de improvisação que chegavam até nós pelo caminho do jazz, que aqui eram digeridos e transformados. Ao realizar esta fusão, seus integrantes chegaram a uma nova sonoridade no universo da canção brasileira, responsável pelas matrizes que geraram, anos mais tarde, a geração da Vanguarda Paulista, que, por sua vez, radicalizou o gesto vocal na canção popular. Desta maneira, foram necessários quase trinta anos para que 0 efeito dessa expansão pudesse ser assimilado pelas novas gerações de artistas. 
2

A SEMIÓTICA DA CANÇÃO E SUA APLICAÇÃO NA ANÁLISE DO COMPORTAMENTO DA VOZ CANTADA 


\subsection{PARA ALÉM DAS ADJETIVAÇÕES}

"Uma ciência da voz deveria abarcar tanto uma fonética quanto uma fonologia, chegar até uma psicologia da

profundidade, uma antropologia e uma história. Deveria ultrapassar amplamente o domínio vocal propriamente dito.

Com efeito, antes da voz há o silêncio. (...) A voz jaz no silêncio; às vezes ela sai dele e é como um nascimento. Ela emerge de seu silêncio matricial. Ora, neste silêncio ela amarra os laços com uma porção de realidades que escapam

à nossa atenção despertada; ela assume os valores profundos que vão em seguida, em todas as suas atividades, dar cor àquilo que, por seu intermédio, é dito ou cantado."

(ZUMTHOR, 1990)

É possível observar na argumentação acima expressa por Paul Zumthor, em seu livro Escritura e nomadismo, o desejo de desenvolvimento de uma ciência que fosse capaz de descrever a riqueza de elementos da voz, além de fazer uma enumeração exclusivamente técnica - uma ciência que pudesse traduzi-la de maneira tão intensa e profunda quanto ela, a voz, é capaz de traduzir os conteúdos de uma obra musical ou mesmo literária. E, de certa forma, quando Zumthor aponta o fato de a voz emergir do silêncio no qual amarra laços e assume valores profundos, ele está sugerindo a existência de uma tensividade geradora, cuja percepção nos leva a uma compreensão sensorial e intelectiva do fenômeno vocal.

De maneira similar, em seu ensaio intitulado O grão da voz (1971), Roland Barthes lamenta o fato de que, para se descrevê-la, só lançássemos mão de incontáveis adjetivações, argumentando que a pobreza descritiva não faria jus a todo conteúdo simbólico que uma voz é capaz de produzir. Ao apresentar o conceito de grão da voz, Barthes nos leva a pensar que essa não é uma elaboração associada a um domínio puramente estético, mas sim à carga expressiva do encontro de uma voz com uma língua, como ele mesmo define, e das experiências de sentido que resultam desse encontro.

Ambos os autores argumentam sobre as significações construídas pelos elementos físicos da voz. E Zumthor (1990) menciona o poder significante em "termos 
de tom, timbre, alcance, altura, registro", e dos valores atribuídos pelas diversas sociedades a cada um desses elementos.

Em O cancionista, Luiz Tatit (1995) refere-se à composição de canções como um exercício no qual se elimina a fronteira entre o falar e o cantar, apontando ainda que caberia ao cantor obter "um permanente equilíbrio entre os elementos melódicos, lingüísticos, os parâmetros musicais e a entoação coloquial".

Sendo a voz, por excelência, um sistema semiótico portador de sentido não só no plano da expressão, mas também do conteúdo, vislumbramos a possibilidade de contribuir para a complementação desse novo campo teórico (Semiótica da Canção) identificando os significados produzidos pelo canto, com seus recursos técnicos e suas expressões emocionais. Para isso, propomos a observação e o estudo dos níveis que compõem o fenômeno vocal pelo viés da existência semiótica, levando em conta que a presença da voz, em qualquer que seja a natureza do discurso, já é em si portadora de sentido.

Desta forma, nas análises aqui desenvolvidas, destrinçamos o componente vocal numa tentativa de elucidar o sentido do gesto interpretativo com base na compreensão dos estados fóricos, do tempo, da velocidade, dos estados juntivos, enfim, do sentido profundo da voz que canta.

\subsection{VOZ E TENSIVIDADE}

Em junho de 1994, Luiz Tatit apresentou como tese para obtenção do titulo de livre-docente o trabalho que resultou no livro Semiótica da canção: melodia e letra (1994), cuja teoria - posteriormente desenvolvida, aprofundada e atualizada em outros trabalhos como O cancionista (1995) e Elos de melodia e letra (2008) - nós nos propomos a utilizar aqui, estendendo sua aplicabilidade também para o campo de análise do comportamento vocal na canção popular. Pretendemos, assim, observar o componente vocal pelo viés da Semiótica da Canção, incorporando a esta os elementos particulares da descrição técnica-vocal, agora vistos pela intenção do gesto interpretativo que comportam, garantindo a expressão do sentido dos textos musical e linguístico. 
Da fala ao canto há um processo geral de corporificação: da forma fonológica passa-se à substância fonética. A primeira é cristalizada na segunda. As relações in absentia materializam-se in praesentia. A gramática lingüística cede espaço à gramática de recorrência musical. $A$ voz articulada do intelecto converte-se em expressão do corpo que sente. As inflexões caóticas das entoações, dependentes da sintaxe do texto, ganham periodicidade, sentido próprio e se perpetuam em movimento cíclico como um ritual. É a estabilização da freqüência e da duração por leis musicais que passam a interagir com as leis lingüísticas. Aquelas fixam e ordenam todo o perfil melódico e ainda estabelecem uma regularidade para o texto, metrificando seus acentos, e aliterando sua sonoridade. Como extensão do corpo do cancionista, surge o timbre de voz. Como parâmetro de dosagem do afeto investido, a intensidade. (TATIT, 1995, p. 15)

Segundo Tatit, o núcleo de identidade de uma canção se constitui pela existência e pela relação de melodia e letra. Ou seja, num estágio ainda virtual, o compositor propõe o entrosamento desses dois componentes (melodia e letra), nos quais ainda inscreve conteúdos que poderão (ou não) ser manifestados em seus estágios posteriores. Nessa etapa virtualizada, estabelecem-se o tempo e o espaço no qual se dará a enunciação, que só existe, segundo Tatit, pela presença de um sujeito. Considerando que a voz humana é o único instrumento capaz de realizar simultaneamente o texto linguístico e o texto musical, e sendo o núcleo de identidade da canção a relação entre esses dois componentes, compete à interpretação vocal o desenvolvimento das duas etapas existenciais subsequentes: a atualização e a realização. O sujeito configurado pelo compositor ganha, então, existência material além da letra, na própria melodia estabilizada pela voz do intérprete. Ou seja, a presença viva da voz atualiza o sujeito, corporificando sua existência numa outra dimensão.

Ainda por intermédio da ação vocal, a produção de sentido extrapola os limites da letra e se reconfigura no gesto interpretativo, podendo mesmo trazer à luz significações expressas no plano de expressão linguística, bem como no plano de conteúdo do discurso musical. 
Desta forma, o intérprete inicia esse processo ao realizar a escolha da própria tonalidade, configurando um campo de tessitura para a atuação de sua voz ou mesmo transcendendo esse campo quando a execução ocupa toda a sua extensão vocal. A escolha da tonalidade é uma etapa inicial de extrema importância, pois, nesse momento, será definido um campo de atuação, levando em conta não apenas se o campo de extensão melódica é comportado pela voz do intérprete, mas também se a sonoridade obtida pela voz na região definida compatibiliza-se com os conteúdos previstos pela composição. Muitas canções apresentam extensão melódica adaptável a várias tonalidades, o que facilita, em princípio, o trabalho do intérprete. No entanto, sempre há uma tonalidade na qual o corpo sonoro da voz se compatibiliza de maneira mais profunda com os textos (musical e linguístico) da canção e que, portanto, exige do intérprete uma atenção extrema na escolha e na definição desse campo.

Definida a tonalidade, entra em pauta o aspecto timbrístico da voz, que pode decorrer tanto da região de tessitura selecionada pelo intérprete quanto de sua intervenção técnica voluntária. A escolha timbrística pode compatibilizar-se com o tempo interno da canção ou, ainda, reconfigurá-lo, acelerando-o ou desacelerando-o segundo o índice de informação ou redundância presente no canto.

A proposta de andamento também pode influir no nível de integração entre melodia e letra presente na composição ou, de outra maneira, revelar um novo tipo de integração conforme o andamento seja mais ou menos acelerado. Essa escolha ainda terá efeitos na articulação rítmica, com valorização maior ou menor dos componentes silábicos consonantais ou das durações vocálicas. A ação do intérprete na compatibilização de todos esses elementos é o que completa e realiza o ciclo semiótico de uma canção.

Considerando que a execução em foco envolve a presença de instrumentos acompanhadores, o desenvolvimento do arranjo completo seria uma etapa posterior ou mesmo simultânea, ocorrendo em consonância com os gestos delineados pela voz e pela interpretação nela configurada, a ela acrescentando os componentes da harmonia e das texturas instrumentais, que, no entanto, não serão examinadas neste trabalho. 


\subsubsection{Passionalização, tematização e figurativização}

No sistema da Semiótica da Canção, Tatit aponta a presença de três tipos diferentes de integração entre melodia e letra: passionalização, tematização e figurativização.

O componente passional da canção se manifesta sobretudo pela disjunção entre sujeito e objeto, que se expressa na melodia pela distância entre seus motivos idênticos e pelo andamento lento, configurando um percurso de busca que nem sempre resulta em encontro. A presença do elemento passional na canção sugere, ao intérprete, espaços amplos para expor as possibilidades de sua tessitura vocal, bem como o trabalho sobre aspectos timbrísticos e musicais, pelos quais a voz configurará as oscilações tensivas e os conteúdos emotivos da obra. Ainda em uma canção passionalizada, os alongamentos das notas e frases musicais podem ser revigorados pela presença de vibratos, que enfatizam o componente dramático do canto e que foram bastante utilizados na canção brasileira nos estilos reconhecidos como samba-canção e seresta, sendo ainda empregados na música sertaneja.

No campo da emissão vocal, a escolha de registros é outro elemento importante na construção dessa expressividade. Por exemplo, a condução da voz em sub-registro ${ }^{9}$ de peito a regiões agudas confere uma percepção de tensionamento físico que muitas vezes reforça, na própria percepção do ouvinte, o componente dramático da interpretação. Da mesma maneira, a emissão em sub-registro de cabeça em região médio-grave pode atenuar a tensão e revelar um sujeito também submetido à paixão, por isso mesmo incapaz de ser dinamizado pelo /fazer/, deixando antever pelo aspecto vocal a instância do /ser/.

Já nos casos em que ocorre o predomínio da tematização, a voz trabalha com pouca expansão no campo da tessitura e a predominância da repetição de motivos melódicos, que muitas vezes se caracterizam como refrãos. Esse processo exige uma ação contínua do intérprete, no sentido de não alterar drasticamente seu canto. Em geral são canções de celebração do encontro, nas quais o conflito ou a disjunção, se ocorreu, já

\footnotetext{
${ }^{9}$ No item 3 deste capítulo explicamos a utilização dos ajustes fonatórios para produção dos registros e sub-registros da voz.
} 
foi resolvida. A identidade dos motivos melódicos, nesse caso, não permite surpresas (saltos intervalares, transposições de tessitura, criação de novas partes, mudanças timbristicas) que alterem o gesto vocal do intérprete e que suspendam sua cumplicidade com os ouvintes.

Desta forma, o espaço para atuação vocal expande-se pouco e o gesto do intérprete configura-se de maneira menos enfática, privilegiando aspectos da continuidade. No entanto, quanto à articulação rítmica, a tematização pode favorecer a intervenção do intérprete, que encontra espaços para criação de novos recortes rítmicos e, portanto, nova configuração do plano da expressão. O cantor João Gilberto, por exemplo, realizou ao longo de sua carreira inúmeras interpretações nas quais é possível observar esse tipo de comportamento rítmico da voz. Em sua gravação da música "Tin Tin por Tin Tin", de Haroldo Barbosa e Geraldo Jaques, ele alterna articulações rápidas e sem prolongamentos de notas, como em "Você tem que dar, tem que dar/ o que prometeu meu bem...", ou ainda em "que eu the mando outra explicando tin tin por tin tin", com frases nas quais os prolongamentos se alinham em significação com todos os planos de linguagem: "o amor não tem fim".

Nas canções menos vinculadas à produção de massa, esse espaço para intervenção do intérprete apresenta-se mais ampliado que naquelas de grande apelo popular, exatamente por contarem menos com a participação ativa do público. No caso da Bossa Nova, e mais especificamente em João Gilberto, a relação construída com a plateia prevê sempre uma etapa em que esta se dedica a ouvir e aprender. A ênfase na repetição permite, desta maneira, que o público assimile a transformação rítmica, passando a repeti-la junto com o intérprete.

Por fim, com o predomínio da figurativização, o intérprete vê ampliado o espaço para as entoações mais próximas à fala, conferindo veracidade e atualidade ao canto. Essa fala, de alguma maneira, já está inscrita na canção de modo mais ou menos perceptível, e o intérprete apenas atenua o elemento musical para fazer falar a voz que canta.

Embora ocorra, na maioria das canções, o predomínio de um dos processos citados, há, de modo geral, como aponta Tatit, uma alternância de procedimentos, o que torna possível detectar em uma canção passional, por exemplo, momentos em que ela se tematiza ou mesmo se figurativiza. Esse fato possibilita ao intérprete elaborar o 
seu canto em função do efeito de sentido desejado. Desta forma, aquilo que se diz orienta a maneira como se vai dizer. Assim, é possível detectar que, se o intérprete permite que a canção se mostre, ela própria apontará caminhos para a interpretação, cabendo a ele, como interlocutor, fazer as escolhas que produzam maior eficácia na comunicação com o ouvinte e que, ao mesmo tempo, particularizem sua visão da obra. É possível, ainda, pelas escolhas realizadas na interpretação, revelar conteúdos pouco aparentes na obra, ou mesmo ressignificar alguns enunciados que jamais foram alterados nas interpretações pregressas. Deste modo, as escolhas realizadas para configurar o canto podem ejetar novos sentidos de dentro das canções.

Ainda que essas escolhas tenham sido feitas de modo intuitivo ao longo de toda a história da canção brasileira, pudemos observar que os grandes intérpretes atuaram nesse campo, demonstrando suas competências na percepção dos elementos inscritos na canção. Da mesma maneira, também pudemos perceber que, a partir dos tropicalistas, esta ação passou a ocorrer com mais frequência por uma apreensão consciente das possibilidades de significação da voz, sem no entanto perder o elo com o seu princípio emotivo.

O cantor apega-se à força do canto, e o cantar faz nascer uma outra voz dentro da voz. Essa, com que falamos, é muitas vezes a emissão de uma série de palavras sem desejo, omissões foscas e abafadas de um corpo retraído, voz recortada pela pressão do princípio de realidade. (...) No entanto, o canto potencia tudo aquilo que há na linguagem, não de diferença, mas de presença. E presença é o corpo vivo: não as distinções abstratas dos fonemas, mas a substância viva do som, força do corpo que respira. Perante a voz da língua, a voz que canta é liberação (...). (WISNIK apud TATIT, 1995, p. 15)

\subsection{NÍVEIS DA VOZ: ELEMENTOS DE FISIOLOGIA E TÉCNICA VOCAL}

Por meio da escuta de fonogramas, é possível detectar que, desde o início da canção midiatizada no Brasil, os cantores já reconheciam a importância de elucidar no canto a significação do texto lingüístico, bem como do componente melódico. Com maior ou menor presença da fala, intuitivamente os cantores populares aprenderam a manipular aspectos da voz para conferir credibilidade ao canto, produzindo no ouvinte a 
crença na veracidade do discurso. Desta forma, muitos aprenderam naturalmente a atuar sobre aspectos físicos, como o timbre e a tessitura, desenvolvendo uma técnica específica que colocasse a voz a serviço de um componente estético compatível com os diversos gêneros da canção popular. Tudo movido pelo desejo de criar uma interpretação singular que ressoasse no ouvinte, materializando por meio da voz a presença do cantor.

Visto que a escuta dos fonogramas permite observar uma inteligência técnica por trás das execuções nas quais o intérprete manipula a voz para produzir reações emocionais, torna-se indispensável que realizemos um detalhamento dos aspectos técnicos e fisiológicos da voz cantada para que, tendo compreensão desses elementos, possamos mergulhar no universo de sentidos construídos pela voz na canção popular do Brasil.

Em nossa dissertação de mestrado, fizemos uma exposição detalhada sobre esses aspectos, que denominamos níveis da voz, o que reelaboramos aqui a fim de possibilitar uma compreensão do gesto vocal, relacionando-o a uma existência semiótica da interpretação.

\subsubsection{Nível físico}

Consideramos pertinentes ao nível físico todos os componentes inerentes à natureza da voz, ou seja, todos os elementos que compõem a voz, independentemente do grau de desenvolvimento técnico obtido pelo intérprete.

\subsubsection{Extensão e tessitura}

Embora sejam comumente compreendidas como sinônimas, essas noções precisam ser devidamente diferenciadas. A extensão implica toda a gama de notas musicais que uma voz é capaz de produzir, do extremo grave ao extremo agudo. Já a tessitura relaciona-se à gama de notas produzidas com o menor esforço físico, resultando em grande qualidade vocal e naturalidade, não apenas na realização do intérprete, mas também na recepção do ouvinte. 


\subsubsection{Registros vocais}

A variedade de alturas percorridas no discurso cantado leva o cantor a utilizar diferentes registros de sua voz. Esses registros, que são os ajustes produzidos pela musculatura, possibilitam que a voz atue não só no campo de tessitura próximo à fala, mas por um campo vocal bem mais amplo, que muitas vezes envolve toda a extensão.

Embora haja alguma divergência de nomenclatura entre os diversos autores que abordaram o assunto, os registros vocais são reconhecidamente três: basal ou fry, modal e elevado.

\section{Basal}

O registro basal ou fry é aquele no qual as pregas vocais encontram-se bastante encurtadas e a mucosa que as recobre, bem soltas (BEHLAU \& REHDER, 1997). O som produzido pela voz atinge uma frequência extremamente grave (strothbass). Em virtude de um índice de crepitação percebido auditivamente na produção desse tipo de som, ele também recebeu o nome de fry (frito).

\section{Modal}

O registro modal, no qual se opera grande parte das vozes falada e cantada, está dividido em três sub-registros, nominados segundo as sensações corporais produzidas pela ressonância: baixo (peito), médio (glótico) e alto (cabeça). Na canção popular, trabalha-se tecnicamente para que o cantor seja capaz de utilizar toda sua extensão vocal, atenuando as quebras naturais entre um sub-registro e outro, ou fazendo uso dessas mesmas quebras caso deseje imprimir uma intenção interpretativa. Ou seja, diferentemente daquilo que é pregado no estudo do canto lírico, a quebra pode ser utilizada como um recurso interpretativo. Do ponto de vista fisiológico, à medida que se encaminha para a produção de notas agudas, a ação física transfere-se do músculo interno (tiroaritenóideo ${ }^{10}$ ) da laringe para o músculo externo (cricotireóideo ${ }^{11}$ ).

\footnotetext{
${ }^{10}$ Músculo interno à laringe responsável pelo relaxamento das pregas vocais.

${ }^{11}$ Músculo externo à laringe responsável pelo estiramento e tensionamento das pregas vocais.
} 


\section{Elevado}

O registro elevado apresenta dois sub-registros: falsete e flauta (assovio). O falsete é produzido por ação indireta das pregas vocais; a laringe é tensionada pelo músculo cricotireóideo e, por consequência, as pregas vocais são alongadas de tal forma que uma pequena fenda se instala entre elas. O resultado produzido é uma voz aguda e, pela presença da fenda, comumente airada. Esse recurso é amplamente utilizado no campo da música popular e, particularmente, na canção brasileira, tornou-se marca vocal de cantores como Milton Nascimento, Caetano Veloso e Gilberto Gil.

\subsubsection{Timbre e significação}

O timbre é o componente físico que diferencia e particulariza uma voz ou mesmo o som de um instrumento. É, por excelência, o componente da identidade, aquilo que nos faz reconhecer a fonte sonora e que pode produzir, em cada um, a sensação de conforto pelo reconhecimento ou de desconforto pela impossibilidade de identificação da fonte sonora. No entanto, muitas vezes, essa mesma impossibilidade pode despertar a atração pelo desconhecido.

No canto popular, o timbre marca a identificação do intérprete e produz, no ouvinte, a crença no discurso, caso se trate de um cantor de sua preferência, ou mesmo a descrença, se ele não nutrir admiração pelo intérprete. E talvez por isso mesmo seja comum que os cantores se apeguem aos seus timbres naturais e se arrisquem pouco na alteração de um padrão vocal já consagrado pelo público.

\subsubsection{Nível técnico}

\subsubsection{Emissão}

No que tange à emissão, a variação de escolha de ressoadores - que são as cavidades da cabeça (nariz, boca, laringe, orofaringe) - pode enfatizar ou atenuar a presença de harmônicos agudos (ressoadores frontais) ou graves (ressoadores posteriores). A voz projetada nos ressoadores frontais tende a resultar numa sonoridade mais compactada, sem escape de ar e com uma presença maior de harmônicos agudos. Já a projeção mais 
posteriorizada, na qual a massa de ar se projeta com maior acento no palato mole, tende a produzir um espectro maior de harmônicos graves, resultando num corpo vocal mais largo e disperso.

Naturalmente, cada cantor, em virtude de sua natureza física, já traz características timbrísticas próprias, que podem ser alteradas pela presença de uma consciência técnica atuando na emissão. Essa consciência aparece, ainda que de maneira intuitiva, em muitos cantores populares, pelo desejo de atuação interpretativa. Ao longo da história de nossa canção, os intérpretes foram descobrindo outras vozes dentro de suas próprias vozes naturais, movidos pelo anseio de criar uma marca interpretativa em consonância com o sentido profundo das canções.

\subsubsection{Nível interpretativo}

\subsubsection{Articulação rítmica}

A articulação rítmica é a maneira como a voz articula os tempos do discurso musical associados ao discurso linguístico; como constrói, no plano da expressão, cada sílaba (ação local), cada palavra (ação local ampliada) e, depois, cada frase (ação global) e cada período (ação global ampliada), atuando na construção de uma significação no campo extenso, mediante ações intensas.

Inicialmente, em nosso trabalho de mestrado, inserimos a articulação rítmica como componente do nível técnico. No entanto, revemos aqui nossa classificação inicial, visto que consideramos, hoje, que o desenvolvimento da interpretação está diretamente vinculado ao modo de dizer, que é produto direto da maneira como o intérprete relaciona a melodia com o texto.

No que se refere à escolha do andamento, essa relação se vincula à canção integral, conferindo-Ihe índices maiores ou menores de passionalização ou tematização, no intuito de traduzir os estados fóricos da narrativa e dos actantes. 
Já do ponto de vista da silabação, é possível observar que se trata de uma ação local que se refletirá no aspecto amplo da interpretação. Esta ação local pode privilegiar os recortes rítmicos (ênfase nas consoantes) ou os prolongamentos vocálicos.

\subsubsection{Timbre manipulado}

A partir do momento em que o cantor faz uso da técnica vocal, dos campos de emissão e da variação consciente de registro, ele pode produzir alterações significativas em seu timbre natural. Essas alterações, inseridas numa interpretação, podem produzir efeito de descontinuidade na escuta, gerando uma nova informação, que atua como elemento de atração na relação com o ouvinte, ainda que de certa forma o convoque à uma participação indireta.

Considerando o tempo tensivo, é possível refletir sobre os índices de aceleração ou desaceleração que um elemento novo provoca na percepção do receptor. O excesso de informações pode provocar uma saturação da capacidade de percepção do ouvinte deixando de produzir empatia dada a dificuldade do reconhecimento. Em sentido oposto, há risco de a falta total de informação provocar um desinteresse, desmotivando a escuta pelo excesso de previsibilidade.

Desta forma, a possibilidade de manipulação do timbre gerando oscilações tensivas pode garantir um grau de eficácia na interpretação que, equilibrando informação e redundância, comunica-se diretamente com o ouvinte.

No que concerne ao timbre manipulado, a atuação pontual do intérprete pode produzir variações localizadas, que por certo interferem no sentido global da obra. Notadamente as cantoras Gal Costa, em seus trabalhos nos anos 1970, Elis Regina e Rita Lee fizeram uso diferenciado dessa possibilidade vocal, permitindo surgir uma nova voz dentro da voz já identificada pelo ouvinte.

\subsubsection{Gesto interpretativo}

De posse de todas as competências técnicas e sensíveis, o intérprete realiza a canção. O gesto interpretativo é a ação que materializa a compreensão do cantor ante os 
conteúdos da composição. Desta forma, ele torna claro os elos de melodia e letra inscritos na composição, ou mesmo define novos elos que só se consolidam pela presença da voz.

O cantor equilibra ou desequilibra intencionalmente todos os componentes de melodia e letra, traduzindo-os por meio da escolha da emissão, do timbre, da articulação rítmica e da capacidade entoativa. Por esse gesto, que vai configurar a qualidade emotiva, é que se manifestam os aspectos passionais ou temáticos da voz, em sintonia com os valores inscritos na composição. 
3

A ESCOLHA DAS CANÇÕES E A
METODOLOGIA DAS ANÁLISES 


\subsection{A ESCOLHA DAS CANÇÕES}

O critério adotado para a escolha das canções foi estabelecido com base na percepção do seu grau de importância no repertório consagrado em um mercado de música que se consolidou nos quase cem anos da indústria fonográfica brasileira. A permanência da canção ao longo dos anos e a presença de regravações foram critérios observados para avaliar o índice de relevância da obra na história da canção popular no Brasil.

É importante destacar que aqui foi realizado um recorte, concentrando essa escolha na produção musical realizada no eixo sudeste desde o início até o final do século $X X$, sem restrição de gênero ou estilo. Dadas as dimensões continentais do País e sua imensa diversidade musical, esse recorte fazia-se absolutamente necessário, pois, caso contrário, seria praticamente impossível, por questões temporais e mesmo técnicas ou estéticas, aprofundar a abordagem das análises. A escolha de repertório focalizou, então, a produção cancional urbana registrada em fonogramas produzidos nas cidades do Rio de Janeiro e São Paulo.

Desde o surgimento das primeiras gravações, o comportamento vocal dos cantores, como se pôde observar, passou por algumas transformações estéticas significativas, visto que o recorte temporal amplo contemplou fases diversas da canção popular. Desta forma, as gravações escolhidas, por pertencerem a épocas diferentes, apresentavam vozes que revelavam, além de seus componentes de individualidade, algum reflexo estético do período focalizado.

Chegamos, então, ao seguinte repertório:

\section{1. "Ave Maria no Morro"}

Composição de Herivelto Martins

Gravações analisadas:

Dalva de Oliveira (ainda como membro do Trio de Ouro formado por ela, Herivelto Martins e Nilo Chagas) - realizada em 1942 João Gilberto - realizada em 1991 


\section{2. "Beatriz"}

Composição de Edu Lobo e Chico Buarque de Holanda

Gravações analisadas:

Milton Nascimento - realizada em 1983

Ana Carolina - realizada em 1999

3. "É o Amor"

Composição de Zezé di Camargo

Gravações analisadas:

Zezé di Camargo \& Luciano - realizada em 1991

Maria Bethânia - realizada em 1999

\section{4. "Falsa Baiana"}

Composição de Geraldo Pereira

Gravações analisadas:

Ciro Monteiro - realizada em 1944

Gal Costa - realizada em 1971

\section{5. "Lábios que Beijei"}

Composição de J.Cascata e Leonel Azevedo

Gravações analisadas:

Orlando Silva - realizada em 1937

Caetano Veloso - realizada em 1995

\section{6. "Linda Flor (Yayá)"}

Composição de Henrique Vogeler, Marques Porto e Luiz Peixoto

Gravações analisadas:

Araci Cortes - realizada em 1929

Zezé Motta - realizada em 1979 
7. "Na Batucada da Vida"

Composição de Ari Barroso e Luiz Peixoto

Gravações analisadas:

Carmen Miranda - realizada em 1934

Elis Regina - realizada em 1974

Ná Ozzetti - realizada em 2009

\section{8. "Samba do Avião"}

Composição de Tom Jobim

Gravações analisadas:

Tom Jobim - realizada em 1965

Gilberto Gil - realizada em 1977

\subsubsection{A escolha dos fonogramas}

Dentro do universo da canção popular midiatizada, foram se estabilizando, ao longo dos anos, alguns critérios de aceitação dos registros fonográficos, a ponto de haver hoje certo consenso de público e crítica a respeito das chamadas "gravações definitivas". Esses critérios de consagração já apontam, por si só, a possível existência de um gesto vocal expressivo o bastante para motivar uma análise.

A partir daí, estabelecemos que trabalharíamos com dois fonogramas: o primeiro registro da composição escolhida e um segundo fonograma, que deveria apontar caminhos opostos para a realização vocal, fato que colaboraria na observação da riqueza e diversidade de elementos contidos em uma composição e destacados nas execuções singulares dos intérpretes.

No percurso para escolha dos fonogramas ocorreram, no entanto, três desvios. O primeiro diz respeito à canção "Samba do Avião". Em vez de tomarmos o registro original dessa canção, realizado pelo grupo vocal Os Cariocas, que se notabilizou por alterar significativamente os traços melódicos da composição original, optamos pela gravação de Tom Jobim, mais identificada com o projeto inicial de sua própria criação.

O segundo desvio deu-se com a inclusão da análise de um terceiro fonograma da música "Na Batucada da Vida". A gravação de Ná Ozzetti (em Balangandãs, 2009) 
foi incluída por revelar outro tipo de elo entre a interpretação e a canção original, contrapondo-se desta forma às versões bastante personalistas, tanto de Carmen Miranda, a primeira a gravá-la (1934), quanto de Elis Regina, cuja regravação aconteceu em 1974.

Por fim, o terceiro desvio deu-se com a inclusão da gravação de Caetano Veloso para a canção "Lábios que Beijei", visto que esta não apontava caminhos opostos para a interpretação. Ao contrário, configurava uma espécie de tributo à gravação original de Orlando Silva.

\subsection{A METODOLOGIA DAS ANÁLISES}

\subsubsection{O protocolo}

Para o desenvolvimento das análises, partimos de um protocolo ${ }^{12}$ inicial em que são observados o andamento, a tonalidade, a tessitura da melodia, a instrumentação, a forma e o ano da gravação. Quando disponível, a informação sobre o arranjador também foi inserida nesse mesmo protocolo.

Analisando esses elementos, pudemos observar que a escolha do andamento está profundamente comprometida com a expressão dos estados fóricos. Algumas releituras analisadas, trabalhando com andamentos diametralmente opostos, poderiam revelar aspectos diferentes dessas disposições emocionais. Ao abordar o andamento como uma escolha que se dá no plano global da realização, seríamos dirigidos também a observar a articulação rítmica imprimindo marcas locais.

No que concerne à tonalidade, a escolha poderia revelar o desejo do intérprete de expor uma determinada região de sua voz que possivelmente se compatibilizaria com o plano do conteúdo das canções. Esta observação levaria à percepção da tessitura e do próprio componente melódico, mostrando que as alterações nesse campo específico poderiam indicar um predomínio maior ou menor de um índice de passionalização ou mesmo de tematização na interpretação. Desta forma, o passo seguinte foi a medição da

\footnotetext{
12 Esse protocolo foi desenvolvido por José Roberto do Carmo Jr. e transmitido durante o curso "A Palavra Cantada: Interfaces", ministrado aos alunos da pós-graduação em 2009.
} 
melodia em semitons, configurando-se claramente o campo melódico abordado e a observação das possíveis diferenças entre uma gravação e outra.

Quanto à instrumentação responsável pelo acompanhamento do intérprete na gravação, foi levada em conta, mesmo não configurando campo para análise neste trabalho, porque tanto poderia apontar um comportamento padronizado, como ocorreu com grande frequência em gravações realizadas até o final dos anos 1950, quanto revelaria, a partir desse período, uma intenção de cumplicidade do arranjo com a abordagem vocal. Mesmo não analisando profundamente a questão do arranjo, consideramos importante a inserção das informações no protocolo para efetuar alguma observação mais pontual que se fizesse necessária.

Completando o protocolo inicial, detivemo-nos na observação da forma musical adotada, fato que se apresenta como mais um elemento na particularização do olhar do intérprete sobre a canção, visto que a repetição de determinadas partes, ou mesmo a supressão de algumas, posiciona o cantor/enunciador no discurso.

Por fim, o último elemento observado foi o ano da gravação, dado que também poderia revelar a presença, no gesto vocal, de algum comprometimento estético com a época, tornando visível aspectos de uma genealogia do canto, ou ainda da inserção de rupturas que se tornariam fomentadoras de novos gestos interpretativos.

\subsubsection{A análise da canção}

Adotando os parâmetros estabelecidos pela Semiótica da Canção, o segundo passo das análises se configurou pela observação da canção em si e de como se estabeleciam os elos de melodia e letra. Com isso seria possível perceber quanto o intérprete se compatibilizaria com elementos já inscritos na canção ou, ainda, quanto ele evidenciaria outros elementos que à primeira vista pareceriam secundários ou mesmo parcialmente inexistentes. Sendo assim, no item intitulado "Sobre a canção", nós nos detivemos em observar o seguinte: o regime dominante de integração entre melodia e letra (passionalização, tematização ou figurativização), os recursos adotados para o desenvolvimento da melodia (gradação, saltos, concentração), o gênero musical 
escolhido pelo compositor (valsa, choro, samba, toada, balada, baião, etc.), na medida em que tal informação poderia revelar aspectos dessa integração.

Os elementos extracancionais também foram levados em conta, uma vez que poderiam não apenas revelar o ponto de partida para a composição, mas também refletir aspectos da tensividade inscritos canção.

\subsubsection{A análise do comportamento vocal}

“A tensividade é um lugar imaginário de operações
onde atuam duas dimensões: intensidade e
extensidade, na primeira, estão os estados de
alma (o sensível), na segunda, os estados de
coisas (o inteligível). É a intensidade que rege a
extensidade. Investigar esse momento é restituir o
sentido dessa experiência humana que consiste
em produzir e interpretar algo significante."

(DINIZ, 2006)

O principal objetivo deste trabalho foi desenvolver uma análise semiótica do comportamento vocal para evidenciar que aspectos da voz do cantor seriam responsáveis pela tradução dos sentimentos inscritos na canção.

Baseados em canções e vozes consagradas, pensamos ser possível compreender de que maneira a inteligência sensível dos intérpretes se posicionou para criar um gesto vocal capaz de expressar emoções e conduzir o ouvinte por estados emotivos compatíveis, garantindo a eficácia da comunicação. Foi preciso, então, esmiuçar a voz para encontrar no nível profundo a base que dá sustentação ao gesto, tornando possível compreender aspectos dos estados fóricos (eufórico / disfórico) e dos estados juntivos (conjunção / disjunção) que se deixam expressar pelo canto.

Valendo-nos da detecção de como as vozes se comportavam, criando marcas na intensidade ou na extensidade, pudemos chegar ao que denominamos Qualidade Emotiva.

Com base nos "Níveis da voz", descritos anteriormente, pudemos observar a realização vocal segundo aspectos físicos, técnicos e interpretativos, para então compreender 
de que maneira as ocorrências em cada um desses níveis foram utilizadas pelos intérpretes com o intuito, ainda que inconsciente, de configurar sentido através do canto.

No nível físico, foram detectadas as características naturais concernentes ao timbre, à extensão e à tessitura, enquanto, no nível técnico, foram impressas pelo cantor as alterações no tipo de emissão que poderiam provocar mudanças em suas características timbrísticas, bem como poderiam possibilitar o acesso aos diversos registros vocais. Já em fusão com o nível interpretativo, foi possível analisar se o intérprete teria feito uso de uma transposição de registro vocal (ou de sub-registros) para evidenciar componentes passionalizados ou mesmo para criá-los onde aparentemente não existiam, estabelecendo um novo elo com a letra. Foi possível verificar se essa mesma intervenção nos padrões de emissão possibilitaram alterações timbrísticas que fizeram surgir outras vozes dentro da voz, revelando, pela interpretação, novos engates actanciais. E ainda detectar, na atuação do intérprete, operações de ajuste na articulação rítmica, reiterando ou mesmo recriando um componente já presente na composição.

Muitas vezes, a necessidade de ajuste prosódico e a explicitação de um desejo de inscrever, de acordo com o componente rítmico, uma nova marca interpretativa sobre a canção levaram, segundo pudemos observar, a alterações significativas no tempo musical, tanto silábico (ação local) quanto frasal (ação ampliada), denotando assim a intenção de construir sentido nos campos intenso e extenso.

Ao analisarmos o componente vocal pelo viés da tensividade, pretendemos compreender as manobras realizadas pelo intérprete para expressar uma qualidade emotiva, criando, por exemplo, marcas na intensidade ao valorizar saltos em direção ao agudo, que destacavam a espera e o efeito de suspensão do tempo, associando esse gesto à expressão de um estado disfórico. Ou, ainda, para criar marcas na extensidade ao valorizar o equilíbrio do canto e a perenidade de um mesmo componente timbrístico da voz, ampliando a percepção da passagem gradual do tempo.

Em virtude do núcleo central deste trabalho ser o comportamento vocal dos intérpretes, limitamo-nos a inserir apenas trechos transcritos das melodias analisadas para que essa visualização ilustrasse e facilitasse a compreensão da análise. No entanto, a inserção do CD com todos os fonogramas analisados mostrou-se indispensável, já que a percepção dos fenômenos sonoros descritos dependiam diretamente dessa escuta. 
4

AS ANÁLISES 


\section{1 "AVE MARIA NO MORRO” (Herivelto Martins)}

Nos anos 1940, o compositor Herivelto Martins, que já possuía muitas de suas composições gravadas por nomes importantes da música brasileira, como Silvio Caldas e Araci de Almeida, atinge uma fase de grande produtividade.

"Ave Maria no Morro", canção que faz parte desse período, foi gravada pela primeira vez em 1942, pelo Trio de Ouro, formado por ele, Dalva de Oliveira e Nilo Chagas. Tornou-se um dos maiores sucessos de público na época, contradizendo, segundo Homem de Mello e Severiano, o compositor Benedito Lacerda, parceiro de Herivelto em alguns sambas, que teria sentenciado o fracasso de público - e, portanto, financeiro da composição.

"Ave Maria no Morro" foi regravada por inúmeros outros intérpretes, tendo recebido até mesmo versões em alemão e italiano. Dentre as principais gravações, cabe destacar as de Elizeth Cardoso, Gal Costa e Mônica Salmaso, além daquela escolhida para esta análise, que foi realizada por João Gilberto em 1991, presente no álbum João.

Embora o compositor decante na letra as belezas da vida no morro e enfatize a existência da religiosidade como base sólida dessa vida coletivizada, a melodia, por sua vez, expande-se pela tessitura e deixa antever melancolia e tristeza. A ênfase no percurso e a presença de saltos sugerindo descontinuidade apontam para um sujeito apartado de seu objeto. Sendo assim, é possível perceber que o texto musical revela aquilo que o texto linguístico insiste em ocultar. 
Nas respectivas gravações, os intérpretes Dalva de Oliveira e João Gilberto estabelecem elos com diferentes elementos da composição, como poderemos averiguar na análise que se segue.

\section{“Ave Maria no Morro” (Herivelto Martins)}

1 Barracão de zinco

2 Sem telhado, sem pintura

3 Lá no morro

4 Barracão é bangalô

5 Lá não existe

6 Felicidade de arranha-céu

7 Pois quem mora lá no morro

8 Já vive pertinho do céu

9 Tem alvorada, tem passarada

10 Alvorecer

11 Sinfonia de pardais

12 Anunciando o anoitecer

$13 \mathrm{E}$ o morro inteiro no fim do dia

14 Reza uma prece, Ave Maria

$15 \mathrm{E}$ o morro inteiro no fim do dia

16 Reza uma prece, Ave Maria

17 Ave Maria

$18 \mathrm{E}$ quando o morro escurece

19 Eleva a Deus uma prece

20 Ave Maria. 


\section{Sobre a canção}

O modelo de compatibilização entre melodia e letra se dá predominantemente pela passionalização, embora seja perceptível, no desenvolvimento de cada parte, um índice de concentração que é central em melodias tematizadas, mas que aqui aparece como recurso secundário da expansão que se verifica no campo extenso da composição. Os saltos presentes entre as partes $A, B$ e $C$ produzem uma descontinuidade que revela os conteúdos disfóricos expressos pela melodia e camuflados substancialmente pela letra.

A parte A se desenvolve de modo concentrado na região médio-grave da tessitura. E é possível observar o caráter asseverativo (corroborado pelo encaminhamento harmônico) que se revela no segundo e terceiro versos, pela presença de uma linha melódica cromática descendente resultante das notas terminativas marcadas nas sílabas em negrito, que descrevem um caminho de volta ao primeiro grau da tonalidade: "Sem telhado, sem pintura/ Lá no morro".

\begin{tabular}{|l|l|}
\hline \\
\hline \\
\hline \\
\hline zinco sem telha & \\
\hline & nom pintu \\
\hline & lá \\
\hline do & \\
\hline ra \\
\hline Barracão de \\
\hline
\end{tabular}

Da parte A para a parte B ocorre uma transposição de registro em direção ao agudo, porém o desenvolvimento melódico, a partir daí, também é concentrado, 
estabilizando-se em região médio-aguda da tessitura. Essa concentração, de certa forma, atenua a passionalização inscrita no campo extenso da canção, visto que a percepção de percurso melódico e, ainda, as descontinuidades impressas pelos saltos intervalares são momentaneamente compensadas.

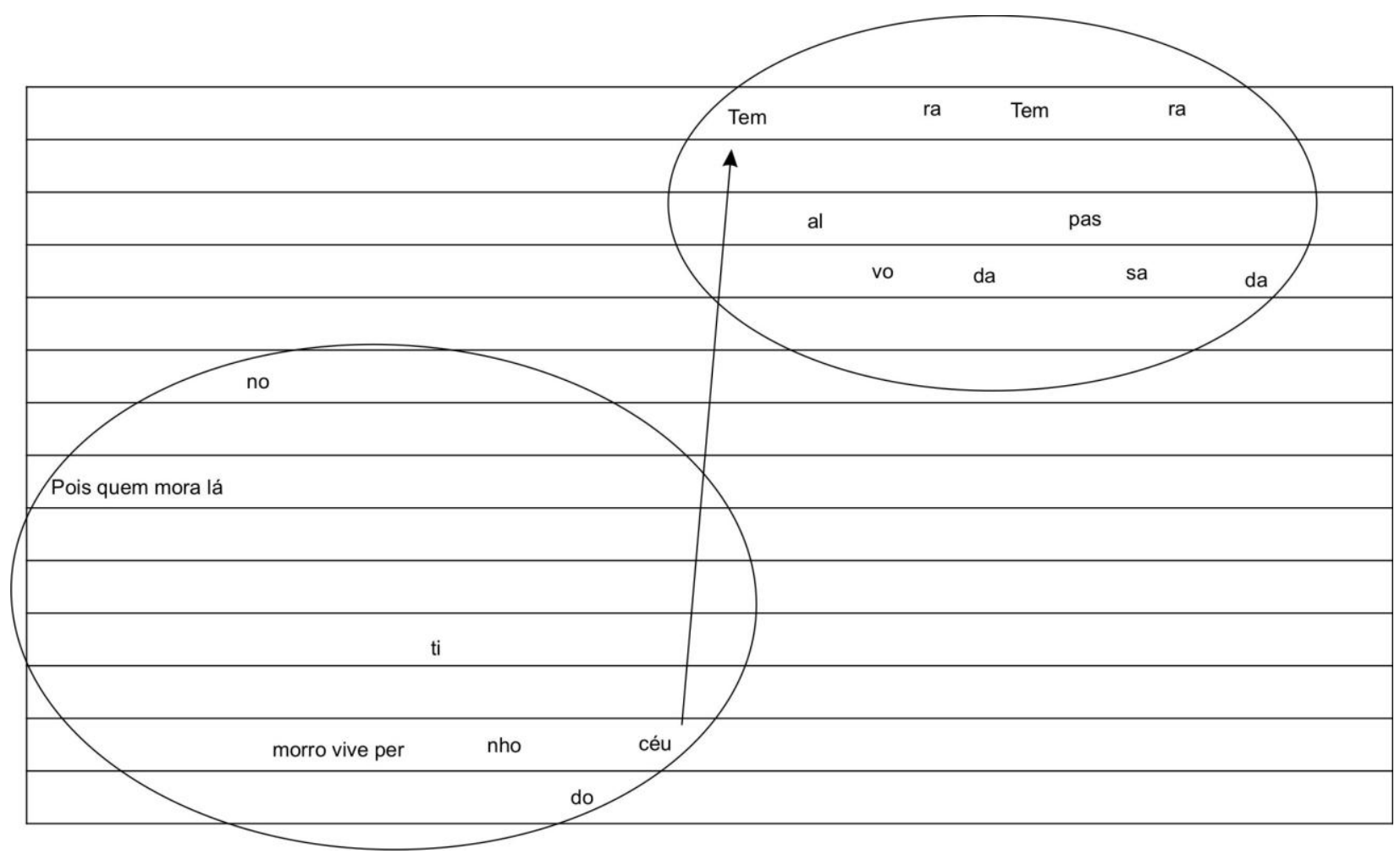

A distância entre as partes A e B indica a presença de um componente disfórico local. No entanto, a instalação de um novo movimento tematizado, que na letra exalta a beleza natural do lugar - "Tem alvorada, tem passarada/ Alvorecer/ Sinfonia de pardais" - dá vazão a um estado eufórico.

Na primeira versão, gravada por Dalva de Oliveira como solista, tendo Nilo Chagas e Herivelto Martins nos vocais (Trio de Ouro), ela apresenta uma forma estendida que conta com uma parte C. Nessa terceira parte, ocorre uma segunda transposição de registro, que amplia ainda mais a tessitura melódica, demonstrando um 
aumento da força dramática, a qual está relacionada com a interpretação e com os elementos inscritos na melodia, que são o tempo todo camuflados por uma suposta conjunção expressa na letra.

A letra fala sobre a vida no morro, mas, ao se referir ao lugar e às condições em que essa vida se dá, em momento algum revela um aspecto tenso pela condição de pobreza. O compositor, ao contrário, atenua a condição do "Barracão de zinco / Sem telhado, sem pintura" ao compará-lo a um bangalô. Também aponta a existência de uma felicidade que não é construída artificialmente: "Lá não existe / Felicidade de arranha-céu". E instala a imediata perenidade dessa felicidade ao apontar: "Pois quem mora lá no morro / Já vive pertinho do céu". Viver perto do céu é usufruir de uma condição extensa de proximidade a Deus, podendo, por isso mesmo, ser provido da grandeza de Sua obra, descrita do verso 9 ao verso 12: "Tem alvorada, tem passarada / Alvorecer/ Sinfonia de pardais / Anunciando o anoitecer".

Ainda que a composição aponte algumas faltas, elas estariam compensadas pela possibilidade de vida num lugar idílico e pleno da presença divina. Essa presença aponta o tema religioso como uma das isotopias do nível discursivo do texto. Esse ambiente de extrema harmonia tem sua imagem de plenitude exposta na cena final descrita pelos versos: "E o morro inteiro no fim do dia/ Reza uma prece, Ave Maria". Denota, então, a união conduzida pela fé.

Mas temos também uma melodia que se expande pelo campo da tessitura, apontando um componente disfórico central, enquanto a letra, em oposição a esse percurso, se compatibiliza com as recorrências de motivo que indicam conjunção eufórica e que constituem o desenvolvimento interno de cada parte da composição.

Se o componente religioso é o grande destinador desta narrativa, podemos entender que o percurso descrito pela melodia espelha aquele que é também descrito pela religião e que separa o homem de Deus, mas que, ao mesmo tempo, permite àquele que se move pela fé viver sob Sua tutela e proteção, compensando com atributos espirituais a ausência de valores materiais. 


\section{Análise do comportamento vocal}

\section{Dalva de Oliveira}

Andamento: 63bpm

Tonalidade: $\mathrm{F}$

Tessitura: 21 semitons

Instrumentação: orquestra (cordas e sopros), piano, contrabaixo, bateria/percussão e vocal Forma: Introdução A B Refrão C A B Refrão

Ano: 1942 (canção relançada no CD Revivendo, s.d. - Faixa 1)

Na versão de Dalva de Oliveira, como integrante do Trio de Ouro, o andamento relativamente rápido contrapõe-se a um tempo interno mais distendido, presente na articulação rítmica da cantora que privilegia os alongamentos vocálicos e as vocalizações nas regiões extremo-agudas da voz, especialmente na parte C da composição. De certa forma, é pela presença desse gesto vocal que se instaura, na interpretação, o elemento ao mesmo tempo religioso e dramático inscrito parcialmente na canção, e que se compatibiliza com a passionalização.

Embora a letra e mesmo o arranjo de base, no caso desta gravação, apontem aqui e ali casos de tematização, a melodia revela aspectos disfóricos, materializados pelas transposições de registro presentes entre uma parte e outra. Ainda que, como vimos na análise da canção, a melodia apresente um alto grau de concentração no interior de cada parte, as transposições de registros já mencionadas, bem como a presença de uma terceira parte extremamente aguda, permitem antever a passionalização como motriz do desenvolvimento melódico.

$\mathrm{Na}$ primeira exposição da parte A, a melodia concentrada desenvolve-se em região média da tessitura, favorecendo que a intérprete elabore um canto cuja emissão frontal soma-se aos prolongamentos de notas, que se realizam com um vibrato curto: "Barracão-- de zin---co/ Sem telha---do, sem pintu-ra". Esse gesto vocal é intensificado pela inserção de appogiaturas ${ }^{13}$ : "Lá no mo--rro/ Barracão é ban-galô".

\footnotetext{
13 "Ornamento que consiste em uma nota, geralmente um grau superior àquela principal (...). Costuma ter a metade da duração da nota principal" (DOURADO, 2004, p. 28).
} 
Depreende-se daí que essas ações locais instalam lentamente o projeto extenso de uma interpretação passionalizada que se desenhará de modo cada vez mais acentuado.

Os vocais realizados por Herivelto Martins e Nilo Chagas, pelo menos nesta parte, não apontam um comportamento de destaque, contribuindo apenas para enfatizar o aspecto tematizado da melodia ou, em alguns momentos, para dar espaço e realce à voz da solista.

Com a entrada na parte $\mathrm{B}$, separada de $\mathrm{A}$ por um intervalo de $8^{\mathrm{a}}$, a melodia passa a se desenvolver em uma tessitura mais aguda, permitindo que a solista ative uma região marcada pela presença de harmônicos agudos, conferindo maior brilho à sua voz. No entanto, a presença constante do vocal, alternando uníssonos com aberturas vocais $3^{\text {a }}$ abaixo, priorizam o canto coletivizado, que de certa forma se compatibiliza com os conteúdos da letra: "E o morro inteiro no fim do dia/ Reza uma prece, Ave Maria".

Já na parte $C$ da canção, a voz da solista ocupa a região extremo-aguda de sua tessitura, enquanto o coro masculino realiza uma base harmônica que colabora para destacar o solo, que nessa hora entoa "Ave Maria", realizando um canto melismático ${ }^{14}$ que remete a uma liturgia popularmente consagrada. Neste sentido, a realização vocal delineia um elo entre a canção popular e o belcanto, cuja influência na música brasileira da época proporcionava uma hipervalorização das vozes agudas, tanto femininas quanto masculinas.

De certa forma, a capacidade de manipulação vocal em regiões tão distantes da fala projetava (e projeta) sobre o cantor uma aura divinizada. Sendo essa característica vista como uma particularidade dos cantores líricos, a realização desse tipo de ajuste vocal por um cantor popular, formado de maneira espontânea, sem que ninguém soubesse exatamente quando ou como essa formação se deu, projetava sobre ele um poder especial de sedução. Neste sentido, esse poder é reforçado quando Dalva de Oliveira abandona a melodia para vocalizar um contracanto, com os vocalistas entoando a melodia principal. Nesse momento, é como se a solista transcendesse a dimensão humana, enquanto a voz materializa corporalmente a prece mencionada na letra.

\footnotetext{
${ }^{14}$ Canto sinuoso cujas notas se sucedem sobre uma única sílaba.
} 


\section{João Gilberto}

Andamento: 56 bpm

Tonalidade: $\mathrm{C}$

Tessitura: 13 semitons

Instrumentação: orquestra de cordas / violão / contrabaixo / bateria

Forma: Introdução A A B Refrão A B Refrão

Ano: 1991 (LP João - Faixa 9)

De certa forma, podemos afirmar que a interpretação de João Gilberto ocupa o extremo oposto do eixo tensivo delineado pela realização de Dalva de Oliveira. A primeira escolha significativa do intérprete diz respeito, neste caso, à forma. Ele suprimiu de sua gravação a presença da parte $\mathrm{C}$, aquela na qual a melodia, por transposição de registros, atinge o extremo agudo. Desta maneira, o cantor opta por uma tonalidade que atua sobre a região médio-grave de sua voz, aproximando ao máximo da fala sua realização vocal cantada.

A introdução realizada pela seção de cordas apresenta descontinuidade rítmica, enquanto a alternância entre os instrumentos produz na escuta uma sensação de esvaziamento, projetando um silêncio parcial pelas vozes do arranjo. Esse gesto local revela o projeto intenso da realização, que é pautada na introspecção e na atenuação do elemento passional, compatível com a proposta estética levada a cabo por João Gilberto a partir da Bossa Nova.

Embora o arranjo não seja objeto de nossa análise, dada a relevância desse comportamento ante o que se desenvolverá na interpretação, achamos importante apontar, aqui, os elos que se estabelecem entre a instrumentação e a voz. Ao término da introdução, a nota sustentada pelas cordas torna-se base para que o violão se destaque com a levada rítmica característica da Bossa Nova, imprimindo assim a marca da regularidade, que passa a ser, desse ponto em diante, o eixo de sustentação da voz.

Na primeira exposição da parte $\mathrm{A}$, o canto está concentrado na região média da voz, e o intérprete trabalha um timbre equilibrado e homogêneo. Esse comportamento vocal que remete à fala é reiterado pela articulação rítmica, que valoriza a continuidade do fraseado, não destacando demasiadamente nenhuma nota ou sílaba. A pouca intensidade na emissão vocal compatibiliza-se com a introspecção anunciada na 
introdução. Essa introspecção é intensificada pela timbragem mais escura da voz, que aponta o componente disfórico, manifestando-se pela contenção vocal, ou seja, percorrendo um caminho bastante diferenciado daquele observado na gravação de Dalva de Oliveira. A interpretação de João Gilberto não enfatiza as distâncias inscritas no percurso melódico, mas as continuidades construídas pela articulação rítmica. Ele praticamente não respira entre uma frase e outra, redimensionando a percepção das frases musicais.

$\mathrm{Na}$ repetição de $\mathrm{A}$, João investe um pouco mais em determinados prolongamentos, como em: "Sem telha--do----- / Lá no mo-----rro", sem fazer uso de vibrato, dado esse que poderia intensificar a percepção do elemento passional, interferindo no projeto estético do intérprete.

\begin{tabular}{|l|l|}
\hline \\
\hline \\
\hline \\
\hline zinco sem telha & \\
\hline & nom pintu \\
\hline & lá \\
\hline do & \\
\hline \multicolumn{1}{|c|}{ ra } \\
\hline Barracão de & \\
\hline & \\
\hline
\end{tabular}

Ainda no final dessa parte, a respiração imperceptível entre o $6^{\circ}$ e $07^{\circ}$ versos "Felicidade de arranha-céu / Quem mora lá no morro" - destaca o processo de soldagem melódica ${ }^{15}$, bem como torna ainda mais evidente o desejo de continuidade inscrito nesse trecho da canção e evidenciado pela interpretação

\footnotetext{
${ }^{15}$ Processo pelo qual cada verso "entrega" seu tom final para o início do seguinte, criando um tipo específico de união, segundo Tatit (comunicação pessoal).
} 
Outra articulação importante nessa primeira parte é a supressão da conjunção explicativa e do advérbio, presentes nos dois últimos versos, respectivamente. Assim, onde na interpretação original havia: "Pois quem mora lá no morro/ Já vive pertinho do céu", passa a haver "Quem mora lá no morro/ vive pertinho do céu". Esse gesto torna ainda mais evidente a ideia de continuidade expressa na canção e compatibiliza-se com o processo de soldagem melódica já mencionado. Desta forma, a voz não se pretende sublime, mas frágil e resignada perante as condições da vida ou as designações divinas.

Com a entrada na parte $B$, a própria transposição que separa uma parte da outra já imprime a descontinuidade, que será parcialmente corroborada pela voz, cuja emissão se torna um pouco mais tensa. O cantor atinge as regiões agudas, sobretudo nos versos "Tem alvorada, tem passarada/ Ao amanhecer", sem uma mudança no ajuste fonatório, no sentido de ativar outro sub-registro da voz. Ele produz as notas mais agudas em emissão de peito, o que demanda um maior tensionamento físico, que é imediatamente captado pela escuta. Essa alteração na emissão pode sugerir um sentimento disfórico mais intenso, mas, no entanto, ela se apresenta de maneira bastante sintética, pois logo depois do verso 12 o cantor retoma sua emissão original. A partir daqui a homogeneidade do timbre vai recuperar a ideia de equilíbrio como projeto extenso.

Durante a terceira repetição da parte $A$, o intérprete realiza alguns deslocamentos e prolongamentos diferentes do ponto de vista da articulação rítmica. No entanto, a percepção de continuidade dentro da estrofe está mantida não só pelo comportamento do violão, mas pelo próprio canto, que liga os versos de 1 a 4 por meio dos prolongamentos de notas e da ausência de respiração. Assim, a voz, que se sobrepõe à base realizada pelo violão, imita uma articulação próxima de um instrumento de corda articulada por arco, aprofundando a percepção de continuidade, visto que não há interrupção de uma frase para outra.

Por fim, na repetição final da parte $B$, o trecho que antes havia sido realizado com algum grau de tensionamento, para expressar um caráter disfórico, dá agora lugar 
a uma emissão completamente relaxada, que permite brincadeiras sonoras com as sílabas: "Sinfonia de pardais". Revela, inclusive, emissões no registro basal /pardais/, explicitando os sentimentos disfóricos expressos na melodia.

\section{Conclusão}

Inicialmente, pelas escolhas tanto de tonalidade quanto de andamento, é possível detectar que cada intérprete compreendeu a canção por um viés diferente e, portanto, construiu uma versão também diferente. No entanto, além das particularidades dos cantores, cabe observar que as referências musicais e estéticas de cada época se fazem presentes em ambas as versões.

A realização de Dalva de Oliveira compatibiliza-se com a estética vigente na época de valorização da potência vocal e de utilização das regiões agudas como prova de virtuosismo e capacidade dramática. A construção de sua interpretação busca ressaltar os componentes disfóricos inscritos na canção e expressos pelas descontinuidades melódicas, ao mesmo tempo em que valoriza a constituição vocal, garantindo eficácia na comunicação estabelecida.

Já a realização de João Gilberto prioriza o projeto extenso de sonoridade homogênea, também compatível com a proposta estética da Bossa Nova. Seu canto revela algum componente disfórico pela escolha timbrística, enquanto a articulação rítmica cuida de valorizar a continuidade, atenuando de maneira enfática qualquer gesto que possa destacar interrupções no percurso melódico. Por esse caminho também se percebe a clara escolha do cantor ao suprimir a parte $C$ da composição, na qual são valorizadas as descontinuidades melódicas, bem como os prolongamentos vocálicos e a expansão da tessitura. Dar voz a esses elementos seria incompatível com o projeto de continuidade sonora inscrito por João Gilberto na canção brasileira. 


\subsection{BEATRIZ \\ (Edu Lobo e Chico Buarque)}

"Beatriz" foi composta por Chico Buarque e Edu Lobo para a trilha sonora do espetáculo O Grande Circo Místico, do Balé do Teatro Guaíra. Baseado no poema de Jorge de Lima, teve concepção e roteiro de Naum Alves de Souza e direção de Emilio di Biasi. O espetáculo reconstruía o universo mágico do circo e de seus personagens através das coreografias e da trilha sonora, cujo primeiro registro fonográfico foi lançado, ainda em LP, no ano de 1983.

O poema de Jorge de Lima fala sobre o filho do médico Frederico Knieps, que, contrariando a decisão do pai, se casa com uma equilibrista e dá início à dinastia do Circo Knieps, pano de fundo para abordar a frágil condição humana. Embora baseados no poema, os compositores recriaram livremente a ideia do circo, construindo com as canções uma narrativa mais onírica e inserindo, por vezes, personagens inexistentes na obra original. É o caso de "Beatriz", que dá título a uma das faixas mais celebradas do disco.

Segundo depoimento de Chico Buarque, publicado em seu próprio site, ante a dificuldade de compor para a personagem Agnes - a equilibrista com quem Otto Frederico se casa -, ele se sentiu à vontade para trocar o nome por Beatriz, em homenagem a Beatrice Portinari, musa inspiradora de Dante Alighieri, propondo para a adaptação também a troca do papel de equilibrista pelo de atriz.

Ainda segundo o depoimento de Chico, ele completa essa homenagem incluindo no sexto verso uma indagação sobre a referida personagem - "se ela dança no sétimo céu?" -, numa menção mais direta à Divina Comédia. No entanto, Chico não parou por aí, conforme pudemos constatar. Além de outras referências à obra de Dante, depreendemos também que a letra da canção é um tributo à paixão amorosa não realizada, inspirada na experiência real do poeta italiano.

Tanto a obra de Jorge de Lima quanto a de Dante Allighieri tratam da frágil condição humana. Ambas realizam uma fusão entre realidade e ficção, e ambas parecem 
ter inspirado Chico Buarque a manter esse movimento dentro de sua composição. Em sua "Beatriz" vivem Agnes e Beatrice Portinari, fundindo realidades diferentes que ganham vida em uma dimensão virtualizada.

\section{Beatriz (Edu Lobo e Chico Buarque)}

1 Olha

2 Será que ela é moça?

3 Será que ela é triste?

4 Será que é o contrário?

5 Será que é pintura o rosto da atriz?

6 Se ela dança no sétimo céu

7 Se ela acredita que é outro país

8 E se ela só decora o seu papel

$9 \mathrm{E}$ se eu pudesse entrar na sua vida

10 Olha,

11 Será que é de louça?

12 Será que é de éter?

13 Será que é loucura?

14 Será que é cenário a casa da atriz?

15 Se ela mora num arranha-céu

$16 \mathrm{E}$ se as paredes são feitas de giz

$17 \mathrm{E}$ se ela chora num quarto de hotel

$18 \mathrm{E}$ se eu pudesse entrar na sua vida

19 Sim, me leva para sempre, Beatriz

$20 \mathrm{Me}$ ensina a não andar com os pés no chão

21 Para sempre é sempre por um triz

$22 \mathrm{Ai}$, diz quantos desastres tem na minha mão

23 Diz se é perigoso a gente ser feliz 
24 Olha,

25 Será que é uma estrela?

26 Será que é mentira?

27 Será que é comédia?

28 Será que é divina a vida da atriz?

29 Se ela um dia despencar do céu

$30 \mathrm{E}$ se os pagantes exigirem bis

$31 \mathrm{E}$ se um arcanjo passar o chapéu

$32 \mathrm{E}$ se eu pudesse entrar na sua vida...

\section{Sobre a canção}

"Beatriz" é, originalmente, uma valsa. A composição expande-se pouco a pouco pelo campo da tessitura, apontando que o regime de integração entre melodia e letra será regido pela passionalização. A forma adotada é um AABA, bastante recorrente no universo da música popular. Não há, contudo, repetição da letra, que desenvolve dentro de cada estrofe uma trajetória crescente compatível com o percurso melódico, o qual, apenas nos dois versos finais de cada estrofe, apresenta uma trajetória descendente cuja última frase reitera o desejo de transformação do estado juntivo expresso pelo sujeito/enunciador.

Na parte $A$, a condução melódica em direção ao agudo não se apresenta de modo abrupto. O ponto culminante é atingido por sucessivas gradações ascendentes, configurando um desejo de conjunção que se expande aos poucos pelo campo extenso, ampliando no ouvinte a expectativa pela resolução musical e dramática. É delineado na melodia um claro percurso de busca, que se compatibiliza com as inúmeras indagações apresentadas no texto. Essa gradação ascendente nos cinco primeiros versos mostra um enunciador em busca de respostas sobre uma mulher idealizada, que não por acaso se traduz na figura de uma atriz. 


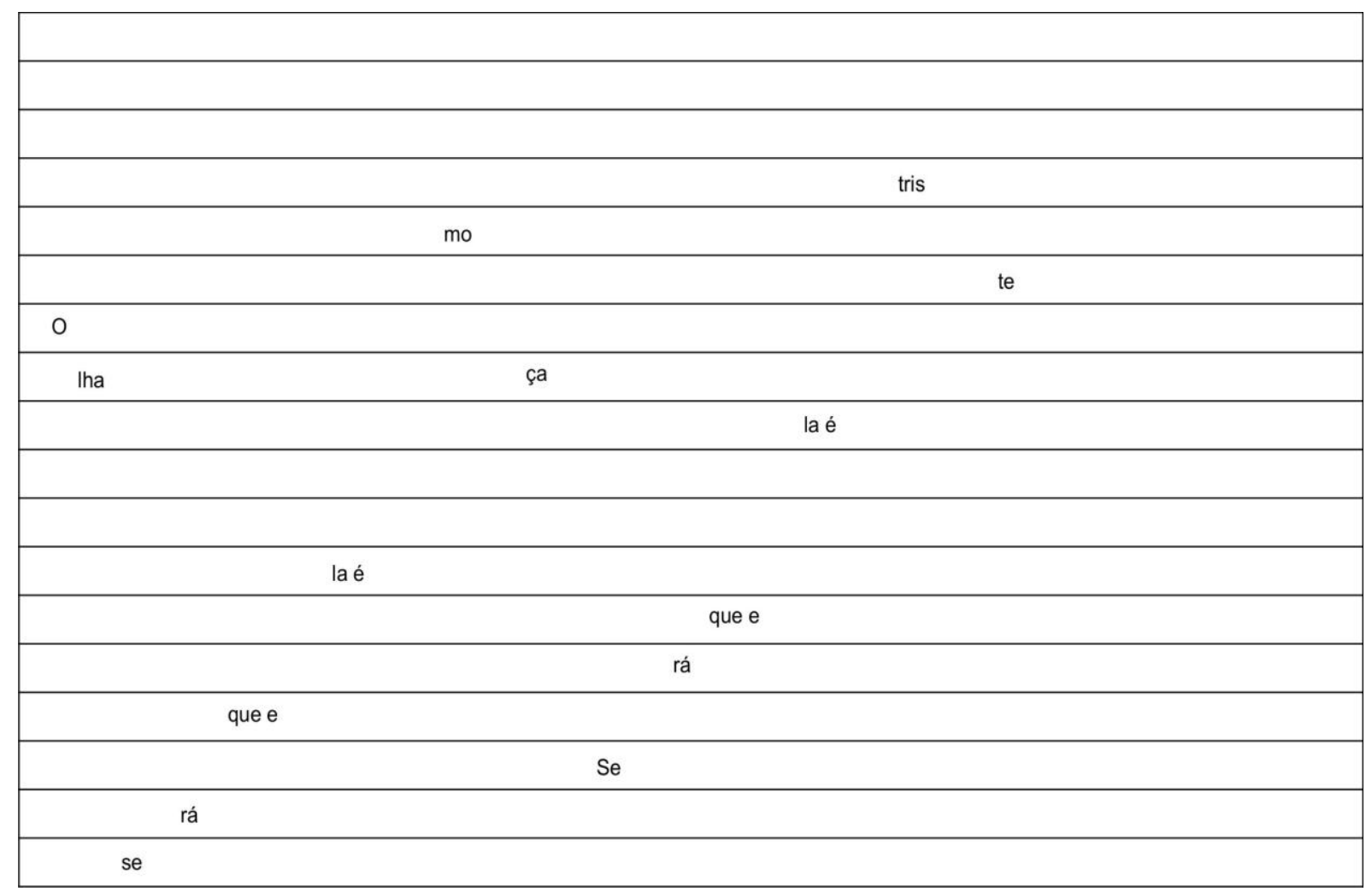

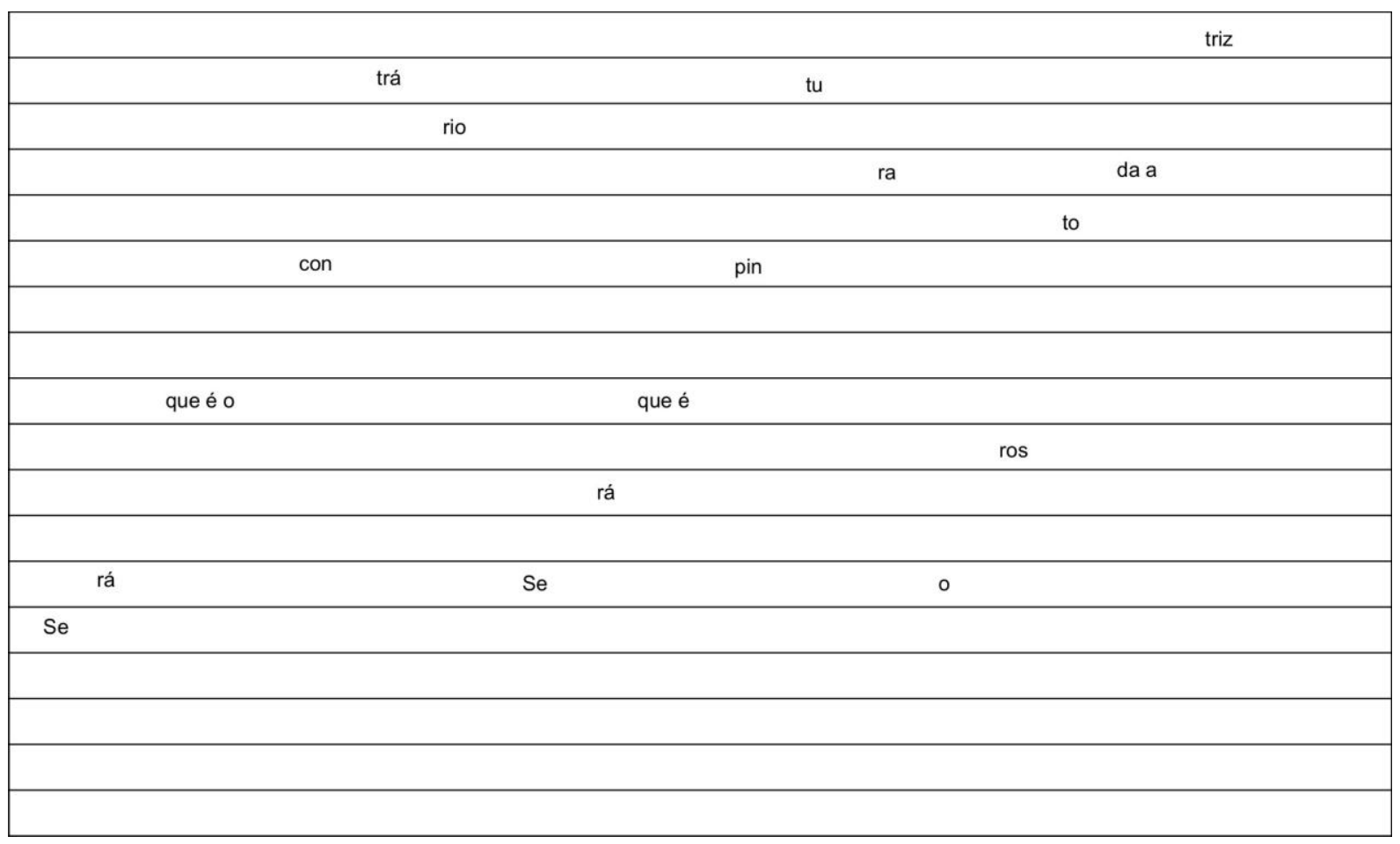


Tudo sobre Beatriz é uma incógnita para o enunciador, e essa sucessão de dúvidas gera, primeiro, indagações sobre seus estados de alma e sua real existência: "Será que ela é moça/ será que ela é triste/ será que é o contrário/ será que é pintura o rosto da atriz?" No oitavo verso, no entanto, a trajetória da melodia se inverte, sugerindo, pelo movimento descendente, uma afirmação asseverativa: "E se ela só decora o seu papel?" Tudo se mostra como se o enunciador soubesse, desde sempre, que o objeto de sua paixão existe apenas numa fantasia enunciada na vida de uma personagem da qual Beatriz é apenas o veículo. No entanto, a intensidade da afeição impede que ele diga isso com segurança e que assuma de vez a inviabilidade da relação amorosa.

As dúvidas sobre a existência real da mulher permanecem, mas na segunda exposição da parte $A$, incidem sobre a vulnerabilidade dessa existência: "Será que é de louça/ Será que é de éter/ Será que é loucura/ Será que é cenário?". As imagens escolhidas dão à personagem feminina um tom de fragilidade ou efemeridade compatível com a mulher impalpável: "Se ela mora num arranha-céu?". No entanto, a melodia que se desenha sobre o décimo sétimo verso, descrevendo uma trajetória descendente, contrapõe-se à predominância de uma inacessibilidade; pela primeira vez, define-se uma imagem mais humana e palpável, que situa a mulher numa provável solidão: "E se ela chora num quarto de hotel?".

A terceira repetição da parte $A$, que pela forma adotada aparece após a parte $B$, também contempla as sucessivas dúvidas sobre Beatriz, mas voltadas especialmente para o seu suposto modo de vida (da qual, aliás, o enunciador deseja tanto fazer parte). Nesta estrofe, o autor explicita sua referência inicial ( $A$ Divina Comédia), como num jogo de adivinhação: "Será que é comédia / Será que é divina a vida da atriz?". Ainda nessa estrofe, ele tece a trama que poderia pertencer tanto à Agnes, a equilibrista do poema de Jorge de Lima, quanto à Beatriz de Dante: "Se ela um dia despencar do céu / E se os pagantes exigirem bis / E se um arcanjo passar o chapéu?".

Na parte $\mathrm{B}$, o décimo nono verso, no qual o enunciador implora à amada que o leve para sempre, está apoiado numa melodia de trajetória ascendente que culmina com o nome da musa: "Sim, me leva para sempre Beatriz". Contrapõe-se ao segundo verso, que, 
apoiado numa melodia de trajetória descendente, reafirma a distância entre o sujeito (eu) e sua amada. Ele implora que Beatriz, na sua condição etérea, possa minimizar a condição terrena do enunciador: "Me ensina a não andar com os pés no chão". Ao mesmo tempo em que clama para que ela o leve para sempre, reconhece a fragilidade desse desejo de conjunção permanente ("para sempre"), que pode ser interrompido por uma ocorrência breve e repentina ("por um triz"), capaz de desviar o destino almejado. Assim, um acontecimento pontual redirecionaria a trajetória global do sujeito. Neste sentido, pode-se compreender que Chico Buarque transporta para a letra da canção tanto a vulnerabilidade da equilibrista, cuja vida também pode estar por um triz, quanto a súbita e inexplicável morte da jovem Beatrice Portinari, que marcou para sempre a vida do poeta Dante Alighieri.

Tudo na letra e na melodia trata da tentativa de materializar uma mulher que parece dotada de uma existência etérea. Mas até o fim da composição esse desejo não se realiza e Beatriz permanece em sua existência fictícia. Daí o termo "atriz" para definir a personagem.

\section{Análise do comportamento vocal}

\section{Milton Nascimento}

Andamento: $58 \mathrm{bpm}$

Tonalidade: D

Tessitura: 25 semitons

Instrumentação: piano /baixo/ orquestra de cordas

Forma: Introdução A A B A Introdução (c/ dobra de voz)

Ano: 1983 (LP O Grande Circo Místico - Faixa 2)

A voz de Milton Nascimento já traz em sua essência o signo da sublimidade, o que justifica imediatamente o convite para que gravasse esta canção. Milton conjuga os dois elementos tensivos que sustentam toda a narrativa: a materialidade do enunciador e, ao mesmo tempo, pelo componente sublime de sua voz, as propriedades etéreas do enunciatário. 
Quando mencionamos o caráter sublime da voz de Milton fazemos uso de uma metáfora para ressaltar que se trata de um timbre que equilibra harmônicos graves e agudos, resultando num componente vocal pleno de nuances e iluminações diferentes por toda a tessitura, tendo, no entanto, como característica principal, o equilíbrio e a plenitude da voz em toda a sua extensão. Esse dado torna-se absolutamente relevante para a escolha do intérprete, visto que a canção se expande por uma tessitura de 25 semitons, exigindo do cantor uma grande flexibilidade técnica para que sua voz se ajuste sem quebras timbrísticas, que, no caso, romperiam o traço lento de expansão da melodia no campo extenso.

As gradações configuram um campo de previsibilidade do desenvolvimento melódico compatível com o regime da desaceleração que norteia a canção passional. O intérprete compatibiliza sua voz com a velocidade desse regime, não imprimindo nenhuma alteração na emissão que resulte em mudança brusca do timbre, fato que provocaria uma aceleração tensiva do componente vocal. Embora a canção explicite o percurso de busca, existe uma esperança de conjunção, que se projeta através da melodia nas frases que terminam a parte $A$ e que nunca são conclusivas: "E se eu pudesse entrar na sua vida?".

A execução vocal desconstrói lentamente o andamento nessas terminações, indicando uma promessa de continuidade. Do ponto de vista musical, essa referência se confirma pela finalização por meio de um movimento cromático que recai sobre o quinto grau da tonalidade, correspondente a um tensionamento harmônico que pede uma resolução. Embora o tonema seja conclusivo, a não-resolução expressa no plano musical configura uma continuidade, com a qual a voz se compatibiliza pelo prolongamento das emissões vocálicas que resultam numa suspensão entoativa.

Os componentes sublimes da canção - que se compatibilizam com as tantas indagações sobre essa mulher inatingível - são o tempo todo reiterados pela conduta vocal de Milton, cuja emissão se estende pelo campo da tessitura, fazendo uso do registro modal em sub-registro de peito, com utilização de voz mista e ressonância glótica em algumas 
terminações agudas, que resultam bastante suavizadas à escuta. A naturalidade e, ao mesmo tempo, a pungência do canto tratam de tecer uma linha contínua entre os extremos da melodia e os estados de alma dos actantes.

A articulação rítmica desprovida de tensão reitera o aspecto de continuidade, que se apresenta no campo extenso da canção e, por vezes, radicaliza o projeto de expansão lenta, característico desse tipo de integração entre melodia e letra. É possível observar que Milton enfatiza a desconstrução rítmica musical (rubatos) sobre determinados fonemas, alterando as durações de tal modo a destacar o que está sendo dito. Esse gesto, que produz uma pequena distensão no ataque rítmico, pode ser observado nos seguintes fonemas:

"Será que ela é triste

Será que é pintura o rosto da atriz

E se ela só decora o seu papel.

Será que é cenário a casa da atriz

E se as paredes são feitas de giz

Será que é uma estrela

Será que é divina a vida da atriz?"

Na parte B, a oposição melódica presente entre o nome "Beatriz", término do primeiro verso, e a palavra "chão", término do segundo verso, de certa forma espelha a oposição semântica que dispara a tensividade expressa em toda a composição. Assim, sobre a última sílaba do nome dela, "triz", ouve-se a nota Re3, enquanto sobre a palavra "chão" ouve-se um Fa2. A primeira frase descreve uma trajetória ascendente, que culmina no nome da mulher idealizada, contrapondo-se à segunda frase, que descreve uma trajetória descendente e asseverativa, na qual o enunciador afirma que Beatriz pode libertá-lo da vida terrena. Expressa-se novamente um desejo de conjunção, ainda que a força da disjunção seja reconhecida. 


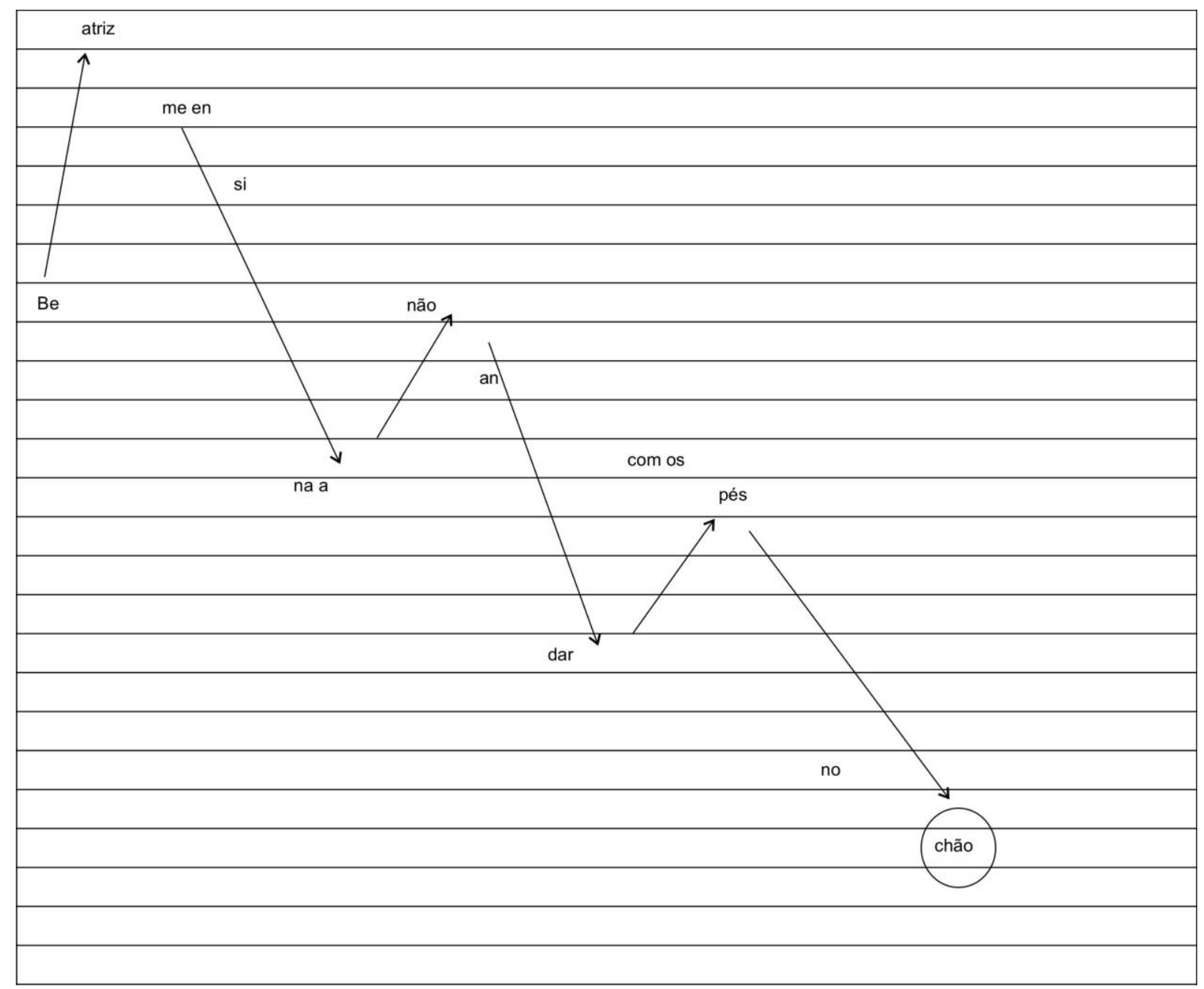

Se é possível depreendermos o conceito de eficácia da canção pela trama entre letra e melodia que o compositor elabora, também é possível perceber um índice de eficácia da interpretação relativo às compatibilizações estabelecidas entre a voz e os elementos inscritos na canção. Nesse sentido, retomamos a exposição inicial que reconhece a matriz desta canção e de sua personagem central (sujeito de papel) em duas mulheres reais, que se tornaram personagens associadas a um alto grau de leveza: Agnes, a equilibrista, e Beatriz, símbolo da fé que conduz o homem (Dante) ao paraíso celestial. Ambas dão origem a "Beatriz", atriz que vive nos sonhos do enunciador sempre encoberta por uma aura difusa que não permite antever suas qualidades físicas, seus estados de alma ou sua real existência. E, ainda que ele atravesse todas as fases narrativas em busca de conjunção, o reconhecimento da disjunção não é traduzido de forma desesperada. 
Há uma naturalidade em reconhecer que talvez Beatriz viva apenas nos desejos do enunciador. A voz do intérprete - ao se apresentar extremamente equilibrada do ponto de vista da emissão, sem alterações de dinâmica, sem ênfase articulatória, com timbre homogêneo e fazendo uso de registros adequados às regiões extremas da tessitura - compatibiliza-se com os valores tensivos inscritos na canção, garantindo a empatia imediata do ouvinte e transportando-o para o interior desse mesmo universo onírico que envolve enunciador, enunciatário e a própria enunciação.

\section{Ana Carolina}

Andamento: 84bpm

Tonalidade: $\mathrm{E}$

Tessitura: 21 semitons

Instrumentação: violões de aço

Forma: Introdução A A B A

Ano: 1999 (CD Ana Carolina - Faixa 14)

A gravação de Ana Carolina transporta a música para o universo autoral da cantora, também compositora. $\mathrm{O}$ andamento é bem mais acelerado que o da versão original; e o compasso, originalmente ternário, transforma-se num quaternário que se concilia com a levada ${ }^{16}$ pop impressa a esta versão. Ao realizar esses movimentos, a cantora diminui consideravelmente a distância entre enunciador e enunciatário, pois tudo o que na versão original conduzia a uma acentuada leveza, fragilidade e ilusão é transformado pela dureza do discurso musical alterado. Se, por um lado, a narrativa perde seu componente mágico, por outro, ela também se humaniza, fazendo alusão a um universo passional de uma relação amorosa que parece ter acontecido. $O$ índice tensivo do canto confere uma existência material à mulher; e, ao retirá-la de sua condição etérea, produz outro efeito de estado juntivo. Tem-se a impressão de que ambos os personagens já estiveram em conjunção e que passaram a um estado de disjunção que o enunciador deseja reverter.

\footnotetext{
${ }^{16}$ Termo utilizado no meio musical para designar o gênero.
} 
A tessitura da melodia original é diminuída em quatro semitons, em virtude das alterações melódicas promovidas pela intérprete. O extremo grave presente na palavra "chão" - "me ensina a não andar com os pés no chão" - é substituído por uma nota cabível na tessitura da cantora (no caso uma nota Sol3).

A realização das notas agudas em sub-registro de peito lhes confere uma tensão expressiva que se transfere à escuta, desfazendo a sensação de distanciamento e o aspecto etéreo do objeto amoroso presentes na primeira versão. A tensão na emissão - somada a um componente de agressividade vocal expressa por uma emissão bastante frontalizada e a uma articulação rítmica com ênfase nas consoantes explicita os elos entre sujeito/enunciador e objeto, ao mesmo tempo em que desconstrói todo o universo mágico da canção original lhe conferindo veracidade.

Ainda no que tange à articulação rítmica, a presença dos ataques consonantais em detrimento das durações vocálicas ativa uma resposta corporal ligada à levada que se estabelece na base harmônica, conferindo materialidade tanto à narrativa quanto ao canto. Do mesmo modo, a aceleração do andamento se desvincula de uma desaceleração intrínseca à composição, presente no projeto inicial de integração entre melodia e letra, desviando a força tensiva de sua trajetória original. Ou seja, a interpretação produz um efeito de tematização sobre a melodia, originalmente passionalizada.

A noção de percurso que não se conclui, estabelecido na melodia original, também é alterado na versão de Ana Carolina, produzindo outras percepções do sentido. Nas frases que terminam a parte A - "E se eu pudesse entrar na sua vida" -, a intérprete insere um tonema descendente, mas, desta vez, alterando a nota para a tônica da escala, e produz a resolução harmônica, assim como a sensação de finalização do percurso. Esse comportamento só não ocorre na segunda repetição da parte A, quando esta se encaminha para o B. Aqui, sim, é mantida a nota de não-resolução harmônica, indicando que uma possível resposta se apresentará na parte subsequente. 
De modo geral, depreende-se desta versão que a intérprete, ao transformar uma valsa lenta e plena de rubatos numa balada em que se pronuncia a regularidade rítmica, evidencia o apelo corporal e converte o aspecto passional idealizado em uma passionalidade realizada, transformando os sujeitos fabulares em sujeitos reais. De certa forma, ela redireciona a trajetória, conduzindo os actantes ficcionais de volta à materialidade que os originou.

\section{Conclusão}

Na pesquisa sobre esta canção, encontramos o depoimento do compositor Chico Buarque, que diz ter desfrutado de total liberdade para realizar a adaptação do poema de Jorge de Lima. Como não encontrasse no nome Agnes uma sonoridade que pudesse disparar o processo de criação da letra, como já dissemos no início desta análise, sentiuse à vontade para alterá-lo, e só aí pôde dar vasão à construção da letra.

Uma canção como esta, composta para integrar uma obra mais ampla, ao ganhar vida própria fora do contexto inicial permite outras leituras analíticas, nem sempre condizentes com os valores inscritos na versão original.

As duas interpretações aqui analisadas ganharam as marcas identitárias de seus intérpretes, constituindo oposição, mas não ilegitimidade. Se a versão de Milton Nascimento reproduziu os elementos inscritos na composição original e passou a ser reconhecida como a versão definitiva da música, a interpretação de Ana Carolina, à parte os juízos de gosto, revelou aspectos tensivos que pareciam ausentes originalmente e, ao mesmo tempo, rompeu com um paradigma vocal. Ao imprimir sua dicção autoral à interpretação, Ana Carolina quebrou o invólucro místico que transformava "Beatriz" em um clássico, transportando-a do universo ideal para o real. Nesse sentido, ela usufruiu de uma liberdade similar à do compositor Chico Buarque, que, ante a impossibilidade de criação poética provocada pelo nome da personagem (Agnes), não hesitou em trocá-lo. 


\section{3 É O AMOR \\ (Zezé di Camargo)}

A década de 1980 assistiu à ascensão das duplas chamadas "sertanejas" ao grande mercado de discos. A trajetória iniciada por Chitãozinho e Xororó abriu caminho para que várias outras duplas, como Leandro e Leonardo, João Paulo e Daniel, Chrystian e Ralf, por exemplo, passassem a figurar no elenco principal das grandes gravadoras, lugar até então restrito aos grandes nomes da MPB, como Roberto Carlos, Maria Bethânia, Simone e Gal Costa, entre outros.

É possível afirmar que, em tempos de um Brasil recém-saído de uma ditadura militar e com o fortalecimento econômico do agronegócio do interior paulista, mineiro e paranaense, as grandes gravadoras passaram a investir pesadamente nos artistas que atendiam aos anseios dessa nova classe econômica em ascensão.

No que se refere a uma genealogia da canção popular no Brasil, podemos afirmar que essas duplas estavam musicalmente mais identificadas com uma tradição do iê-iê-iê romântico estabelecida pela Jovem Guarda do que propriamente com a realização de duplas como Tonico e Tinoco, Tião Carreiro e Pardinho, ou mesmo Cascatinha e Inhana. Ao contrário destas, as novas duplas sertanejas apresentavam um repertório de canções cujo tema central era a relação amorosa, que aparecia vestida por arranjos nos quais a viola, instrumento essencial à sonoridade da música caipira, não encontrava mais lugar.

Esses artistas passaram a ser os pilares de sustentação econômica das gravadoras, em substituição àqueles eminentemente populares, como Waldick Soriano, Odair José e Sidney Magal, que haviam desempenhado papel similar na década anterior, sem todavia usufruírem do mesmo status artístico. Essa música passa a ser realizada em um espaço estritamente profissional, no qual são realizados produtos com alto nível de excelência tecnológica, cada vez mais padronizados e consumidos tanto pelas camadas populares quanto por essa nova classe média alta.

Se na década de 1970 as gravadoras se interessavam em manter em seus quadros os artistas da chamada MPB, que mesmo vendendo pouco conferiam prestígio às empresas por seu poder de atingir um público mais intelectualizado, com essa mudança de 
perfil do grande público consumidor esses artistas vão se tornando menos atraentes para as multinacionais, que passam a investir predominantemente nos grandes nomes da chamada música sertaneja.

Neste cenário é que surgem Zezé di Camargo e Luciano. A canção "É o Amor", lançada em 1991, tornou-se o primeiro grande sucesso comercial da dupla. Oito anos mais tarde, foi reinterpretada pela cantora Maria Bethânia.

A análise que propomos a seguir busca identificar a atuação do intérprete, no intuito de reconfigurar o sentido de uma obra e mesmo revelar referenciais estéticos inscritos na canção que podem ser mais ou menos evidenciados pela interpretação.

\section{É o amor (Zezé di Camargo)}

1 Eu não vou negar que sou louco por você

2 Tô maluco pra te ver

3 Eu não vou negar

4 Eu não vou negar sem você tudo é saudade

5 Você traz felicidade

6 Eu não vou negar

7 Eu não negar você é meu doce mel

8 Meu pedacinho de céu

9 Eu não vou negar

10 Você é minha doce amada, minha alegria

11 Meu conto de fada, minha fantasia

12 A paz que eu preciso pra sobreviver

13 Eu sou o seu apaixonado de alma transparente

$14 \mathrm{Um}$ louco alucinado meio inconsequente

15 Um caso complicado de se entender

16 É o amor

17 Que mexe com minha cabeça e me deixa assim

18 Que faz eu pensar em você e esquecer de mim 
19 Que faz eu esquecer que a vida é feita pra viver

20 É o amor

21 Que veio como um tiro certo no meu coração

$22 \mathrm{E}$ derrubou a base forte da minha paixão

$23 \mathrm{E}$ fez eu entender que a vida é nada sem você

\section{Sobre a canção}

A canção apresenta três partes distintas: A B e refrão, e o regime de integração entre melodia e letra é a passionalização.

A estratégia de negação da negação, adotada pelo enunciador, instala processos reiterativos corroborados pela melodia, que se desenvolve de maneira análoga, respectivamente, nos versos 1, 4 e 7 - "Eu não vou negar que sou louco por você/ Eu não vou negar sem você tudo é saudade/ Eu não vou negar você é meu doce mel" - e 3, 6 e 9: "Eu não vou negar". Sobre o verso 9, ocorre a transposição de registro que dará início à ampliação do percurso melódico, sendo depois adotada uma nova estratégia persuasiva do enunciador perante o enunciatário.

A parte A desenvolve-se numa região média da tessitura, e, embora o primeiro salto melódico seja de $8^{a}$, os motivos se desenvolvem percorrendo uma distância melódica menor. Ainda que o sujeito reconheça aqui sua condição de submissão afetiva ao ser amado e sua impossibilidade de transformar sozinho o estado de tristeza no qual se encontra, esse reconhecimento se dá, como já vimos, por meio de negações.

Na parte B, inicia-se o projeto de expansão pelo campo da tessitura, marcada com a transposição de registro já assinalada e a mudança de estratégia persuasiva. A descontinuidade no percurso melódico explicita o estado de disjunção, que move o sujeito na busca pela conjunção com o objeto. A partir daqui a melodia passa a ocupar a região aguda da tessitura, e o sujeito reconhece enfaticamente sua condição de dependência, deixando claro, agora, que todo o sentido de sua vida está atrelado à presença da mulher amada. É o sentimento amoroso que imprime nele o querer ser e o poder ser, que se configuram como os estados modais que possibilitam a existência do percurso. Desta forma, é esse mesmo sentimento (o amor) que detém a função de 
destinador manipulador. É ele quem imprime o desejo de conjunção que o enunciador/destinatário busca realizar ao longo da canção.

Do ponto de vista da melodia, essa condição é compatível com a presença de motivos reiterativos no interior das frases que, neste caso, pela permanência em região aguda, reafirmam seu caráter passional, como ocorre no trecho "Você é minha doce amada minha alegria/ Meu conto de fadas minha fantasia/ A paz que eu preciso pra sobreviver" e, depois, em "Eu sou o seu apaixonado de alma transparente".

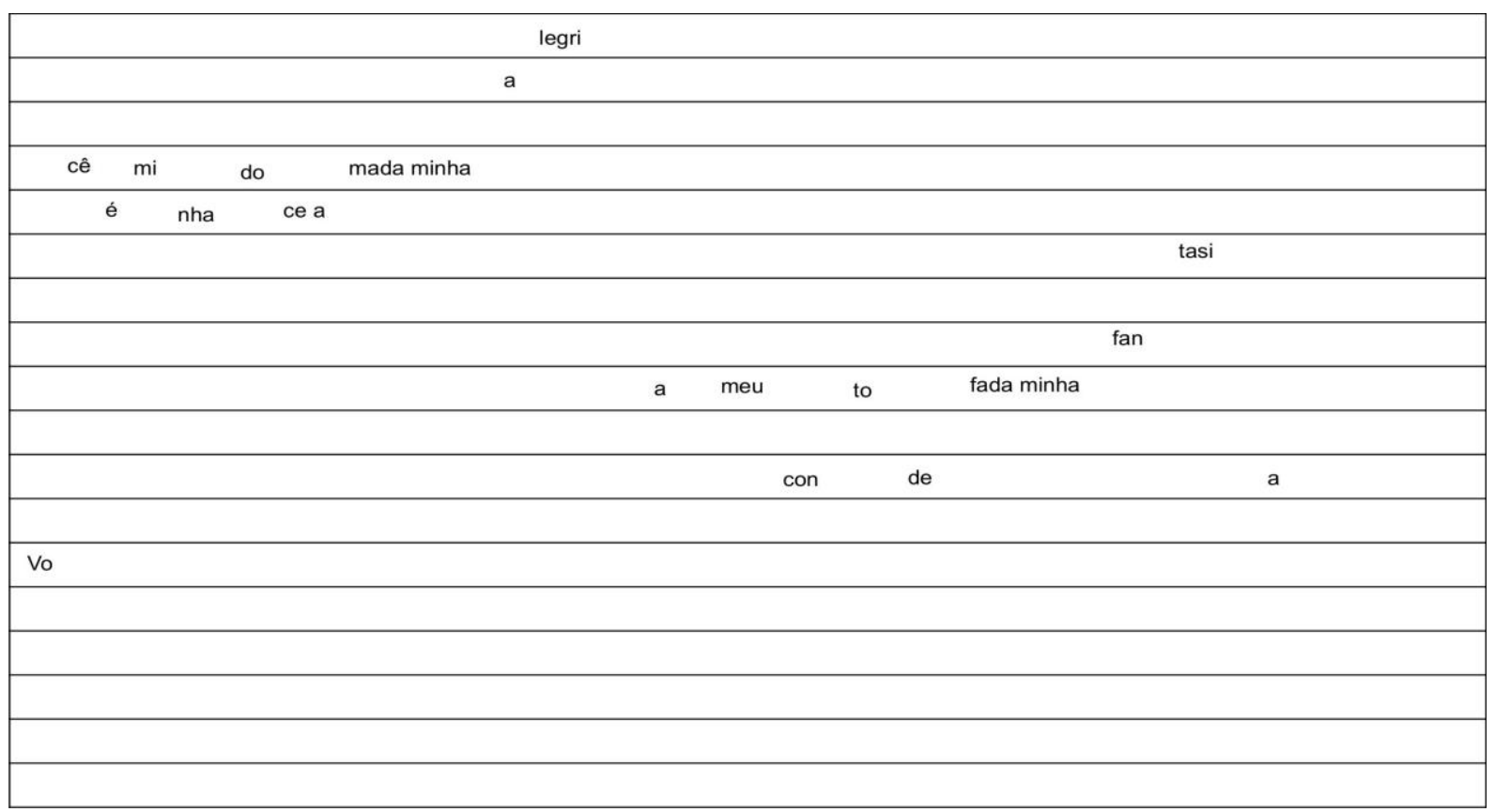

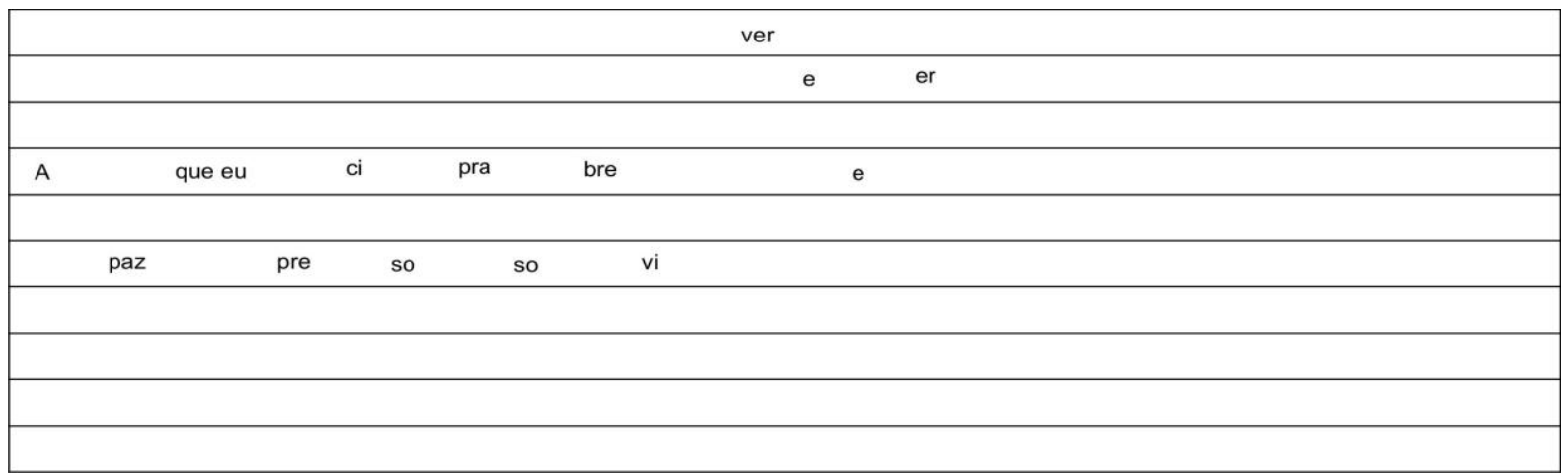


Por toda a letra, o sujeito apaixonado reconhece que a felicidade está associada à realização amorosa e que a presença do objeto (a mulher amada) é absolutamente responsável por todos os seus estados emocionais, sejam eles disfóricos - "Eu não vou negar sem você tudo é saudade" - ou eufóricos: "Você traz felicidade".

O projeto de expansão pelo campo da tessitura, que se configura de maneira progressiva pelas partes A e B, atinge assim o ápice durante o refrão - "É o amor.." -, no qual o sujeito reconhece seu estado passivo diante do sentimento amoroso e sua incapacidade de prosseguir sozinho. Os movimentos reiterativos se compatibilizam com a letra e imprimem certo grau de tematização que torna o refrão bastante assimilável, garantindo a eficácia da comunicação. No entanto, por meio da expansão pelo campo da tessitura, a passionalização se reafirma como mecanismo central de integração entre melodia e letra.

\section{Análise do comportamento vocal}

\section{Zezé di Camargo \& Luciano}

Andamento: 72 bpm

Tonalidade: $\mathrm{B}$

Tessitura: 17 semitons

Instrumentação: teclado, guitarra, baixo, bateria, orquestra

Forma: Introdução A B Refrão B Refrão fade out

Ano: 1991 (LP/CD Zezé di Camargo \& Luciano - Faixa 1)

De um modo geral, nas duplas dessa nova fase da chamada música "sertaneja", o papel do cantor de voz aguda é praticamente o de um solista, ainda que, no aspecto cênico, a existência de cada integrante seja reconhecida artisticamente pelo público, que devota a cada um o mesmo estado de paixão. Do ponto de vista do produto fonográfico, porém, a mixagem ${ }^{17}$ cuida de explicitar a importância da voz mais aguda, destacando-a à frente da segunda voz e também da instrumentação. Aliás, na própria

\footnotetext{
${ }^{17}$ Processo realizado em estúdio, pelo qual são misturados os diversos instrumentos e vozes gravados em diversos canais separados.
} 
classificação das vozes, primeira e segunda, já é possível ler uma hierarquia, que nas duplas atuais é traduzida de maneira mais evidente. Sendo assim, para a realização desta análise, a participação de Luciano não será levada em conta do ponto de vista interpretativo, visto que não é possível detectar em sua voz aspectos que realmente tornem diferenciada sua intervenção vocal.

Quanto à instrumentação utilizada no arranjo, chamamos atenção para o fato de o acompanhamento ser feito por uma banda (baixo, guitarra, teclado, bateria), cordas sintetizadas e flautas. Toda a opção pela sonoridade do arranjo enfatiza a presença do timbre agudo da instrumentação, que se compatibiliza imediatamente com o timbre de voz do cantor principal. Desta forma, podemos considerar que há um plano extenso de sonoridade para toda a realização musical, que parte da estética ditada pela voz. Ainda no que concerne ao arranjo, a opção por um pulso regular e um andamento ligeiramente acelerado imprimem à realização um caráter dançante, programado para mobilizar grandes plateias, movidas tanto pelo apelo somático quanto pelo passional.

Passemos, então, à observação do comportamento vocal do cantor Zezé di Camargo.

Na parte A da composição, na qual a melodia se apresenta em região média da tessitura, já é possível detectar alguns gestos e ações locais que pretendem construir uma progressão para o desfecho emotivo da voz, que se processará na parte $\mathrm{B}$ e culminará no refrão. É possível detectar uma emissão vocal ligeiramente guturalizada, que produz uma leve metalização dos agudos. Também, de maneira leve, já ocorre um primeiro ataque laríngeo, que resulta auditivamente num choro, procurando assim destacar o elemento emotivo do sujeito/enunciador.

Esses dois gestos podem ser observados no primeiro verso, destacadamente nas palavras em negrito: "Eu não vou negar que sou louco por você". A conclusão se dá com a emissão de um vibrato rápido, atenuado pela inserção de ar na voz. No prosseguimento dessa parte - "Tô maluco pra te ver/ Eu não vou negar" -, as finalizações tanto do $2^{\circ}$ quanto do $3^{\circ}$ verso apresentam um vibrato nas sílabas assinaladas, com ar também projetado sobre o verbo negar. Ambos os gestos se compatibilizam com a condição submissa do enunciador e reforçam a imagem de fragilidade construída por ele. 
No $4^{\circ}$ verso, o prolongamento da sílaba final "cê" - "Eu não vou negar sem você"---vem acompanhada por uma metalização acentuada do timbre. Esse recurso enfatiza a ausência como motivadora do complemento - "tu do é sauda-de" -, frase na qual Zezé articula as sílabas em destaque de maneira bastante acentuada, estabelecendo um contraste com a palavra sauda--de, sobretudo pela duração impressa na sílaba central. Simultaneamente, o enunciador imprime uma articulação rítmica que destaca uma ação e reconhece, de novo, a submissão ao estado passional expresso pela duração na palavra saudade. Desta maneira, ele também contrapõe ações locais que espelham uma condição global.

$\mathrm{Na}$ segunda parte, mantém-se a utilização do timbre como recurso básico para impressão de um estado emocional. Esse gesto chega ao extremo no 9o verso - "Eu não vou negar" -, quando ocorre uma combinação que concentra na mesma frase o timbre metalizado, o aumento da intensidade (musical), a emissão chorada e a ênfase na duração da sílaba final, que se projeta sobre uma nota aguda da tessitura.

No $10^{\circ}$ verso, o intérprete faz uso do registro elevado sobre a sílaba inicial de alegria, quando passa para o falsete, voltando a seguir para o registro modal. Esse recurso produz efeito de quebra na emissão, reiterando a imagem de fragilidade do sujeito apartado do ser amado. No $13^{\circ}$ verso, ele faz uso do mesmo recurso, desta vez sobre o adjetivo transparente, obtendo assim um efeito de sentido no plano de expressão como consequência da manobra vocal.

Com a chegada ao refrão, revela-se o componente máximo de passionalidade expresso pela voz. Embora no verso 17 Zezé faça uso do falsete, é possível perceber que uma manobra na mixagem reposiciona a voz quanto ao volume, fazendo que a quebra não resulte em diminuição de intensidade (musical). Assim, por todo o refrão, excetuando-se o verso já mencionado, a voz ocupa regiões agudas da tessitura, fazendo uso do registro de peito, o que confere uma percepção de tensionamento que se compatibiliza com a passionalidade expressa no texto. Soma-se a essa articulação a ênfase nas durações que se projeta por todas as frases, alongando de maneira mais veemente as sílabas finais de cada verso. Nesse momento, o enunciador reconhece sua condição de total submissão ao amor. Este estado pode ser resumido pelos 
versos 18,19 e 23: "Que faz eu pensar em você e esquecer de mim/ Que faz eu esquecer que a vida é feita pra viver/ E fez eu entender que a vida é nada sem você".

\section{Maria Bethânia}

Andamento: 58 bpm

Tonalidade: $\mathrm{G}$

Tessitura: 17 semitons

Instrumentação: piano e orquestra de cordas

Forma: Introdução A B Refrão B Refrão Coda

Ano: 1999 (CD A Força que Nunca Seca - Faixa 3)

A gravação de Maria Bethânia atua de maneira bem diversa do projeto original da canção, pela escolha tanto do andamento quanto da instrumentação. Esses elementos, somados à particular articulação rítmica da intérprete, convidam o ouvinte, logo de início, a uma participação mais contemplativa.

O tom grave faz que a voz se articule de modo a enfatizar a presença da fala; e a percepção do sorriso por traz da articulação da cantora revela um sujeito em conjunção com seu objeto, demonstrando, por meio da canção, a felicidade instalada pelo sentimento amoroso. Pela presença da voz, o sentido de continuidade prevalece sobre uma aparente descontinuidade imposta aos actantes pela presença de um antissujeito que não é explicitada na letra. Esse novo sentido revelado completa a ideia de conjunção e torna claro que, embora a pessoa amada possa não estar presente, o estado amoroso em si é motivo de felicidade e de celebração.

O início da interpretação, no qual Maria Bethânia aparece acompanhada apenas pelo piano, abre espaço para que a cantora instale elementos de figurativização que explicitam a articulação rítmica teatralizada que the é particular. $O$ vibrato atenuado presente nos finais de frases também complementa essa articulação, suavizando o que há de grandiloquência na composição. 
O pulso começa a ficar mais definido com a entrada das cordas ainda na parte A, mas essa definição se consolida, de fato, na parte B, quando a levada é explicitada pelo piano. No entanto, ainda que a estabilização do pulso possa enfatizar a presença do elemento musical, ao rearticular acentuações de palavras que estavam alteradas originalmente pela imposição da música sobre a letra, a intérprete trata de explicitar a dominância da fala em sua realização.

A projeção gradual do ritmo imprime uma lenta mudança sensorial que convida o ouvinte a uma participação um pouco mais ativa. Esse movimento também expande a ideia de celebração, e o foco inicial, que mantinha apenas a pessoa amada como destinatário, agora se mostra levemente ampliado.

$\mathrm{Na}$ altura do refrão, em vez de se concretizar a ideia de expansão e ampliação da carga dramática, Maria Bethânia realiza um movimento contrário, com uma contenção na emissão que modera o fluxo tensivo e redireciona a interpretação para o campo da intimidade. Embora seja possível detectar um componente de tensão na emissão dos versos "É o amor/ Que mexe com a minha cabeça e me deixa assim", o que se observa na frase seguinte é que Bethânia atenua o gesto vocal imprimindo um pouco de ar na voz: "Que faz eu pensar em você e esquecer de mim". Isto vai revelar novamente o sujeito modalizado pelo /ser/ submetido à paixão, mas em estado de conjunção, celebrando a presença da mulher amada. Esse comportamento que se alterna entre a tensão e o relaxamento vocal são repetidos nos demais versos que compõem o refrão, fazendo sempre reiterar no plano da expressão o sentido configurado no plano do conteúdo.

\section{Conclusão}

De modo geral, temos visto, ao longo deste trabalho, o quanto a interpretação pode reconfigurar o sentido de uma canção, produzindo efeitos diversos nos ouvintes. No exemplo ora analisado, deparamo-nos com essa produção de sentido articulada basicamente pelo componente vocal, que traduz de maneira enfática o enunciatário 
ausente, no caso da gravação de Zezé di Camargo, ou o enunciatário presente, como é sugerido pela gravação de Maria Bethânia.

A gravação de Zezé di Camargo, pela escolha de tonalidade, explora a região aguda da voz do cantor. Soma-se a isso o timbre metalizado e a opção por uma emissão pautada pela força da projeção sonora, sugerindo que o enunciador se dirige a alguém que não está efetivamente próximo. A conduta vocal adotada mostra um sujeito em estado de disjunção com o objeto, em busca desesperada para estabelecer a conjunção. A abordagem do canto que valoriza os prolongamentos de notas, bem como o volume mais intenso, enfatiza a percepção do percurso e o esforço para que o distante objeto amoroso seja atingido, tornando possível a transformação do estado juntivo. Outros recursos presentes na voz, como o choro e o vibrato, valorizam a perda, a distância e a carência, bem como reforçam a percepção de um estado de tristeza causado pela ação implícita de um antissujeito que impede a realização desse amor.

Em oposição a isso, configura-se o canto de Maria Bethânia, que se realiza em região grave da voz. Ao adotar uma emissão que alterna entre a quase fala e a estabilização da melodia, ela simplifica a percepção do percurso melódico, retirando relevância das ações do antissujeito $e$ atenuando $o$ aspecto negativo da passionalização, que seria a de ter o objeto amoroso ausente.

Os diversos componentes da voz, como o sorriso por trás da articulação e a dinâmica baixa, indicam a celebração da felicidade produzida por esse estado, e, ainda que o objeto amoroso não esteja presente, a presença do amor em si justifica a celebração. De fato, o canto de Maria Bethânia explora um outro estado afetivo também expresso nessa letra. Ao atenuar a disjunção exposta no componente melódico, ela aponta um caminho oposto daquele percorrido pelo canto do compositor e redimensiona o projeto de integração entre melodia e letra, mostrando que a maneira de cantar pode relativizar os elos inscritos na canção. 


\subsection{FALSA BAIANA (Geraldo Pereira)}

A gravação de Ciro Monteiro, realizada em 1944, tornou "Falsa Baiana" o primeiro grande sucesso de público da carreira do compositor Geraldo Pereira. Com a consagração, a canção foi regravada inúmeras vezes por muitos outros artistas, como Roberto Martins, Roberto Silva e João Gilberto, entre outros.

A segunda versão escolhida para ser analisada neste trabalho é aquela realizada por Gal Costa em 1971, no LP Fa-tal: Gal a todo vapor, gravado ao vivo. A própria cantora já havia feito uma gravação de estúdio, que está presente em seu disco Legal, de 1970; no entanto, este registro ao vivo apresentava uma série de novas informações no componente vocal, por isso foi escolhido para análise. Ambas as versões são bastante influenciadas por um caráter bossanovista, porém, nesta regravação, o componente da improvisação é predominante e chama atenção pelos novos elos que são construídos com a canção popular da época. Outro dado interessante é que, embora João Gilberto seja o principal modelo vocal da cantora, no caso desta canção, a gravação do cantor é posterior à de Gal. Aparece em seu LP de 1973, o que sugere um possível trânsito de influências mútuas entre os dois artistas.

"Falsa Baiana" se alinha a várias outras obras, de outros autores, que no universo da canção popular exaltam figuras emblemáticas da nossa cultura, como o malandro, por exemplo. Num diálogo constante com a tradição, o compositor Caetano Veloso criou, no final dos anos 1980, "A verdadeira baiana", que foi também gravada por Gal Costa em seu CD Plural, cujos primeiros versos sintetizam: "A verdadeira baiana sabe ser falsa / salsa, valsa e samba quando quer.....

\section{Falsa Baiana (Geraldo Pereira)}

1 Baiana que entra na roda só fica parada

2 Não canta, não samba

3 Não bole nem nada

4 Não sabe deixar a mocidade louca

5 Baiana é aquela que entra no samba de qualquer maneira 
6 Que mexe, remexe, dá nó nas cadeiras

$7 \mathrm{E}$ deixa a moçada com água na boca

$8 \mathrm{~A}$ falsa baiana quando cai no samba ninguém se incomoda

9 Ninguém bate palma

10 Ninguém abre a roda

11 Ninguém grita:

12 Oba! Salve a Bahia, sinhô!

13 Mas a gente gosta quando uma baiana quebra direitinho

14 De cima em baixo

15 Revira os olhinhos e diz:

16 "Eu sou filha de São Salvador!"

17 Eh eh meu sinhô!

\section{Sobre a canção}

Em "Falsa Baiana", o modelo de integração entre melodia e letra é regido pela tematização. Nela o compositor enaltece as qualidades da verdadeira baiana, que sabe como ninguém se portar na roda de samba. Assim, valoriza a matriz cultural e étnica, reforçando subliminarmente a presença da Bahia como geradora do samba, que ganhou outras nuances no Rio de Janeiro.

A composição se desenvolve em duas partes distintas, $A$ e B, ambas no modo maior. As reiterações rítmico-melódicas atuam em conformidade com a letra, seja para reafirmar as características negativas da falsa baiana - "que entra na roda só fica parada / Não canta, não samba/ Não bole nem nada/ Não sabe deixar a mocidade louca" -, seja, ao contrário, para enaltecer os gestos positivos da verdadeira baiana: "que mexe/ remexe dá nó nas cadeiras/ E deixa a moçada com água na boca". A valorização do componente reiterativo minimiza a percepção do percurso melódico e, ainda que a tessitura da melodia seja considerável, o que marca presença são os recortes rítmicos. 

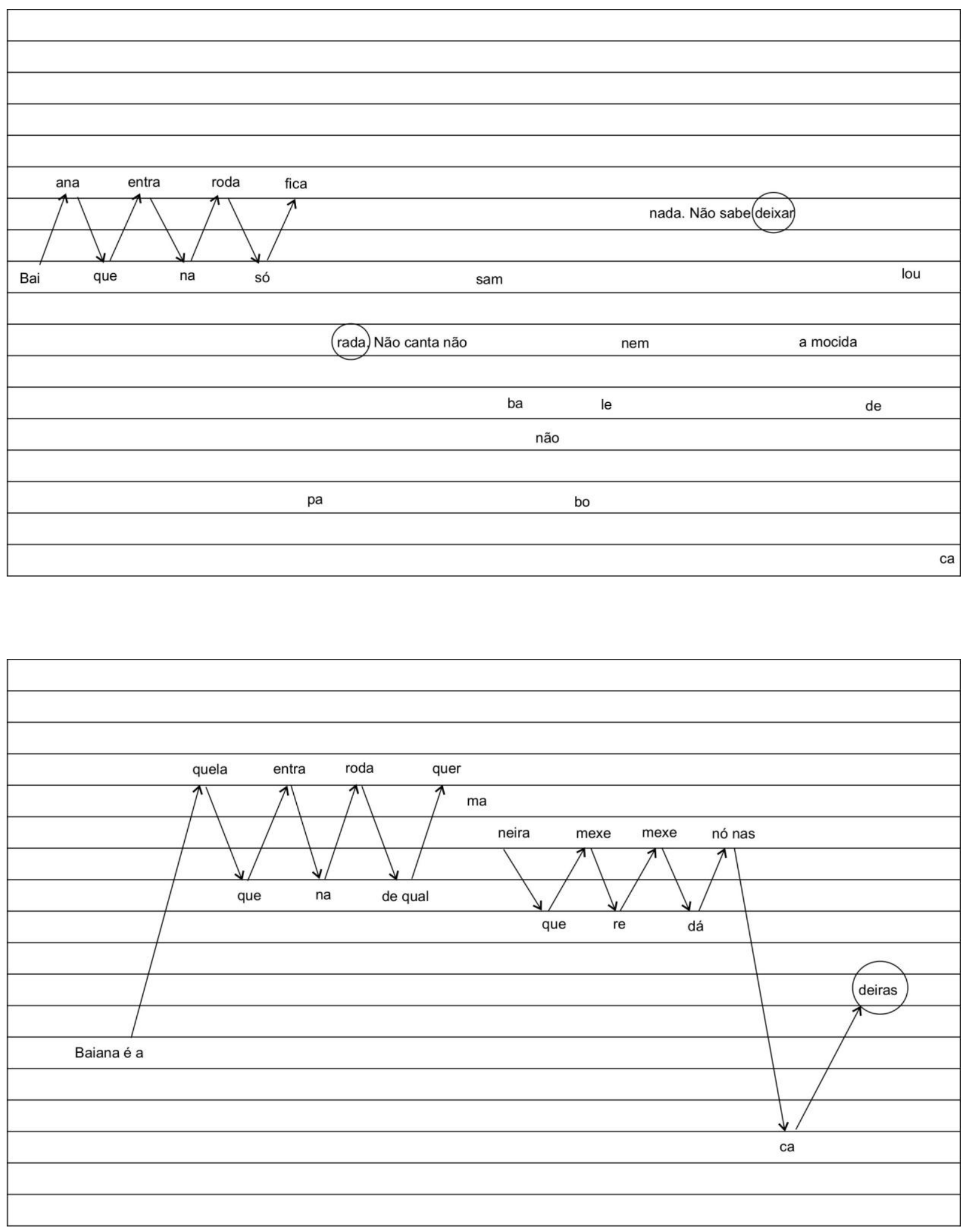


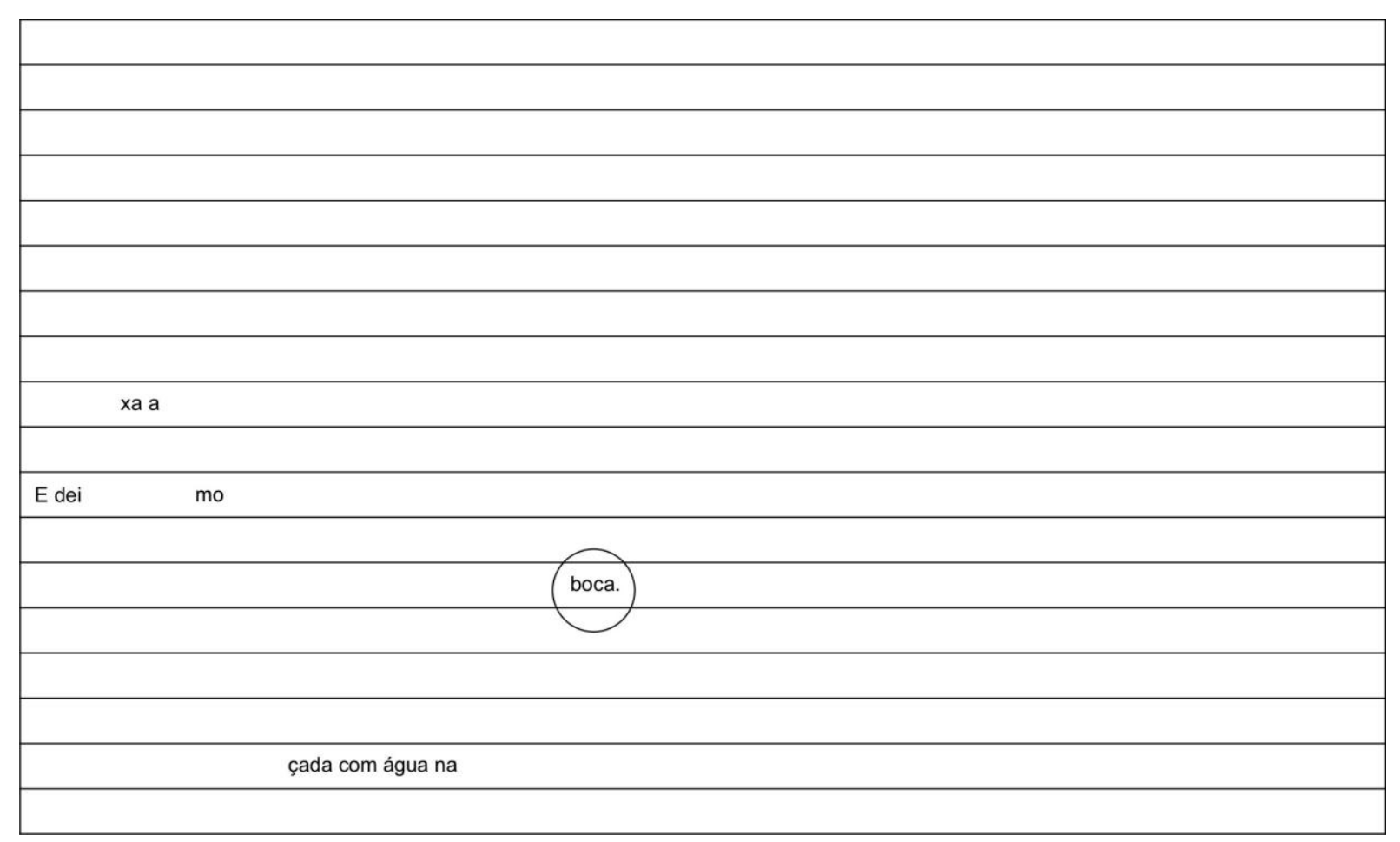

A integração entre melodia e letra está dividida entre a tematização e a figurativização, que atua para recobrir de figuras tanto a falsa quanto a verdadeira baiana. Pensamos ser possível, também, estabelecer entre ambas uma relação de sujeito e antissujeito, visto que uma existe em oposição à outra.

Desta forma, estabelece-se entre a falsa e a verdadeira baiana um eixo tensivo que as posiciona nas extremidades, no que concerne tanto à intensidade, quanto à extensidade. A falsa baiana é aquela "que não samba / não mexe, não bole/ não sabe deixar a mocidade louca"; ou seja, ela reúne todos os atributos que a desqualificam como baiana, e permanece nessa condição, uma vez que nada ocorre para transformar esse estado. Já a verdadeira baiana - "que mexe, remexe, dá nó nas cadeiras/ e deixa a moçada com água na boca" - reúne todos os atributos que a tornam reconhecível como legítima e usufrui dessa condição em todos os momentos de sua vida. Isso porque, aconteça o que acontecer, suas respectivas características vão sempre defini-las como verdadeiras ou falsas, sem qualquer traço de transição. Ao mesmo tempo, podemos identificar que a falsa baiana tem sua condição regida pelo /ser/, visto que está submetida a um estado que a coloca numa situação passiva diante dos estímulos 
musicais, enquanto a verdadeira baiana segue regida pelo /fazer/, respondendo positivamente aos estímulos somáticos que se originam no gênero musical (samba).

O compositor decanta a verdadeira baiana por meio de uma oposição simples que expõe as vicissitudes da falsa baiana, fazendo que ambas sejam materializadas no universo cancional.

\section{Análise do comportamento vocal}

\section{Ciro Monteiro}

Andamento: 84 bpm

Tonalidade: $\mathrm{F}$

Tessitura: 17 semitons

Instrumentação: flauta, cavaquinho, violão, pandeiro, trombone (Regional de Benedito Lacerda)

Forma: Introdução A A B A (instrumental) A B Coda

Ano: 1944 (canção relançada no CD Revivendo: Sambistas de Fato, s.d. - Faixa 1)

Ciro Monteiro é uma das vozes que a partir dos anos 1940 contribuiu para a fixação do samba pós-Estácio de Sá, ou seja, o samba modernizado, distanciado do maxixe e já com uma identidade rítmica bastante estabilizada. Esse tipo de samba era chamado na época de samba sincopado.

A tonalidade escolhida expõe a região médio-grave do intérprete, e o corpo da voz apresenta-se bastante denso e com uma emissão equilibrada, o que the confere homogeneidade. O equilíbrio timbrístico resultante corrobora os processos reiterativos da melodia e ajuda a consolidar, no campo sonoro, as figuras tanto da falsa quanto da verdadeira baiana, porque a voz produz credibilidade na escuta.

Ciro não faz uso de vibrato e, desta forma, a voz pode expressar com mais precisão o componente rítmico da composição. Apenas na conclusão do verso número 4, na finalização da primeira parte da melodia, quando se apresenta um pequeno espaço para duração da nota, ele utiliza um vibrato curto, somado a um ligeiro escurecimento do timbre. Essas duas ações por parte do intérprete reforçam no campo sonoro a expressão do desejo: "e deixa a moçada 
com água na bo—ca-“. ${ }^{18}$ Ao mesmo tempo, enfatizam o elemento masculino da voz, o que reafirma a condição do cantor/enunciador.

Já na segunda exposição do tema, Ciro Monteiro realiza uma alteração na articulação rítmica que também reforça a produção de sentido. No verso número 6 , no qual originalmente a letra dizia "que mexe, remexe dá nó nas cadeiras", ele canta "oi que se mexe, remexe dá nó nas cadeiras". Enfatiza, assim, por meio da recomposição rítmica do fraseado, a imagem da dança sensual da baiana.

A presença desses elementos no canto revela a dimensão profunda do envolvimento do intérprete com a composição. A maneira de cantar ocupa-se não apenas dos valores estéticos do próprio canto, mas do desejo de materializar, por meio da voz, a veracidade do discurso cancional.

No verso número 12, Ciro quase abandona a entoação cantada para valorizar a presença da interjeição: "Obal". Da mesma maneira, no verso 17, ele também redimensiona a presença do canto para enfatizar o gesto de celebração: "Eh eh meu sinhô!". Esses procedimentos atenuam o elemento musical do canto e cedem lugar à fala, que materializa a presença viva do enunciador.

Após o solo instrumental, que se realiza sobre a harmonia da parte A da composição, o intérprete retoma o canto. Desta vez, reitera os procedimentos vocais que, na primeira exposição, produziram efeitos sobre a percepção dos elos entre os recursos da letra e da melodia veiculados pela voz. Além de fazer a opção pelo escurecimento do timbre no final do verso 4 , ele desloca a finalização da palavra "boca", aumentando a duração da primeira sílaba e atacando a segunda no contratempo. Estas ações locais no gesto interpretativo reforçam, mais uma vez, a expressão do sentido, visto que dão um novo colorido à maneira de dizer. $\mathrm{E}$ a escolha desses gestos, especialmente no caso do cantor Ciro Monteiro, compatibiliza-se com a ideia de valorização do componente rítmico, que é também por onde se revelam e se materializam os atributos da verdadeira baiana.

Já no verso 12, nesta segunda exposição, Ciro abandona completamente a linha do canto para dar lugar à fala explicita: "Oba! Salve a Bahia sinhô!". Ao abandonar

\footnotetext{
${ }^{18}$ A opção do texto em negrito é para destacar o momento em que ocorre o escurecimento do timbre. Já os traços apontam a duração ampliada das vogais.
} 
a melodia, ele realiza um movimento de aproximação com o ouvinte, visto que poderia ser ele próprio (o ouvinte) a dizer o texto, empolgado pela imagem da baiana dançando.

\section{Gal Costa}

Andamento: 75 bpm

Tonalidade: A

Tessitura: 18 semitons (ampliando para 23 nos improvisos)

Instrumentação: violão (tocado pela própria cantora)

Forma: Introdução A A B A B A (improvisação) A (improvisação) B Intro (forma completa) Intro (forma completa 2 vezes com silabações e improvisação) Intro (meia forma com diminuição do andamento)

Ano: 1971 (LP Gal Fatal a Todo Vapor - Faixa 15)

No início dos anos 1970, a figura de Gal Costa já estava consagrada e associada a uma imagem de sensualidade, que se reafirmaria cada vez mais nos anos seguintes, com trabalhos como Índia, Cantar, Caras e Bocas e Água Viva, entre outros. Após a década de 1960, tendo a televisão se firmado como grande veículo de massa, a imagem do artista passou a ser um complemento direto do gesto vocal. Gal Costa, consciente dessa força, consolidou uma performance cênica apoiada em uma imagem vocal de extrema sensualidade, associada a ícones de feminilidade muito consolidados em nossa cultura. Em 1975, a consagração da atriz Sônia Braga no papel de Gabriela - personagem de Jorge Amado transportada para a televisão - remetia diretamente à voz de Gal Costa, que interpretava o tema de abertura da novela. O somatório das imagens de ambas sintetizava, na época, o ideal de uma mulher brasileira em seu estado mais puro.

O canto de Gal foi construindo uma cumplicidade com essa identidade cênica, a ponto de ser possível detectar em sua voz o componente de sedução e feminilidade que se tornaram suas marcas interpretativas. Essas marcas estão associadas a um timbre claro e definido, à suavidade na emissão, bem como à tessitura predominantemente aguda.

No caso desta gravação em análise, ocorre uma fusão entre enunciador e sujeito da enunciação, visto que, na voz da cantora, a letra ganha outro sentido, como se ela, ao se referir à baiana que sabe como se portar no samba, fizesse uma alusão a si própria. Esse movimento da 
artista na configuração de uma interpretação bastante personalista já foi observado nas linhas deste trabalho, quando nos detivemos no protocolo de análise da gravação.

Gal reduz consideravelmente 0 andamento e amplia a tessitura da melodia com as inserções de linhas de improviso. Assim, a tessitura, que nesta versão seria de 18 semitons e ocupava, pela escolha de tonalidade, a região médio-aguda da voz da intérprete, se vê ampliada para 23 semitons. É possível depreender desses gestos que Gal Costa injeta na canção um conteúdo de passionalização que não está previsto no projeto inicial do compositor. Também chama atenção a forma musical escolhida pela intérprete, que amplia o projeto original da canção e abre espaço para a inserção de linhas de improvisação, dado o grande número de repetições das partes.

O acompanhamento realizado apenas pelo violão, tocado pela própria cantora, já aponta o caráter bossanovista que conduzirá a interpretação. Essa ideia de junção com a Bossa Nova é reforçada, de início, pelas percussões vocais e, depois, pelo tema que Gal utiliza na introdução vocalizada, o mesmo cantado por João Gilberto na introdução de "Meditação", em seu disco de 1960. No entanto, ainda na introdução, ao repetir a estrutura harmônica, Gal Costa rompe com o enunciado ao inserir frases improvisadas que expõem uma tessitura ampliada e já prenunciam o comportamento vocal que se desenvolverá por toda a execução.

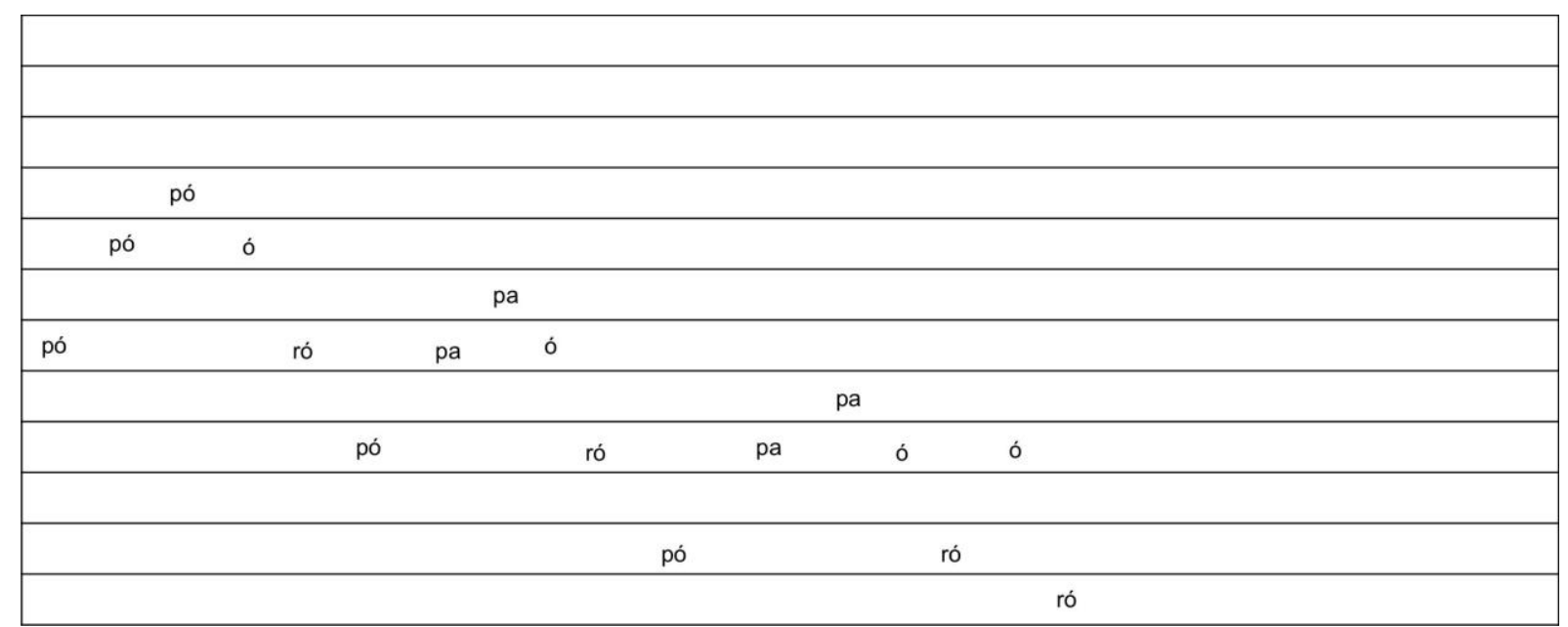




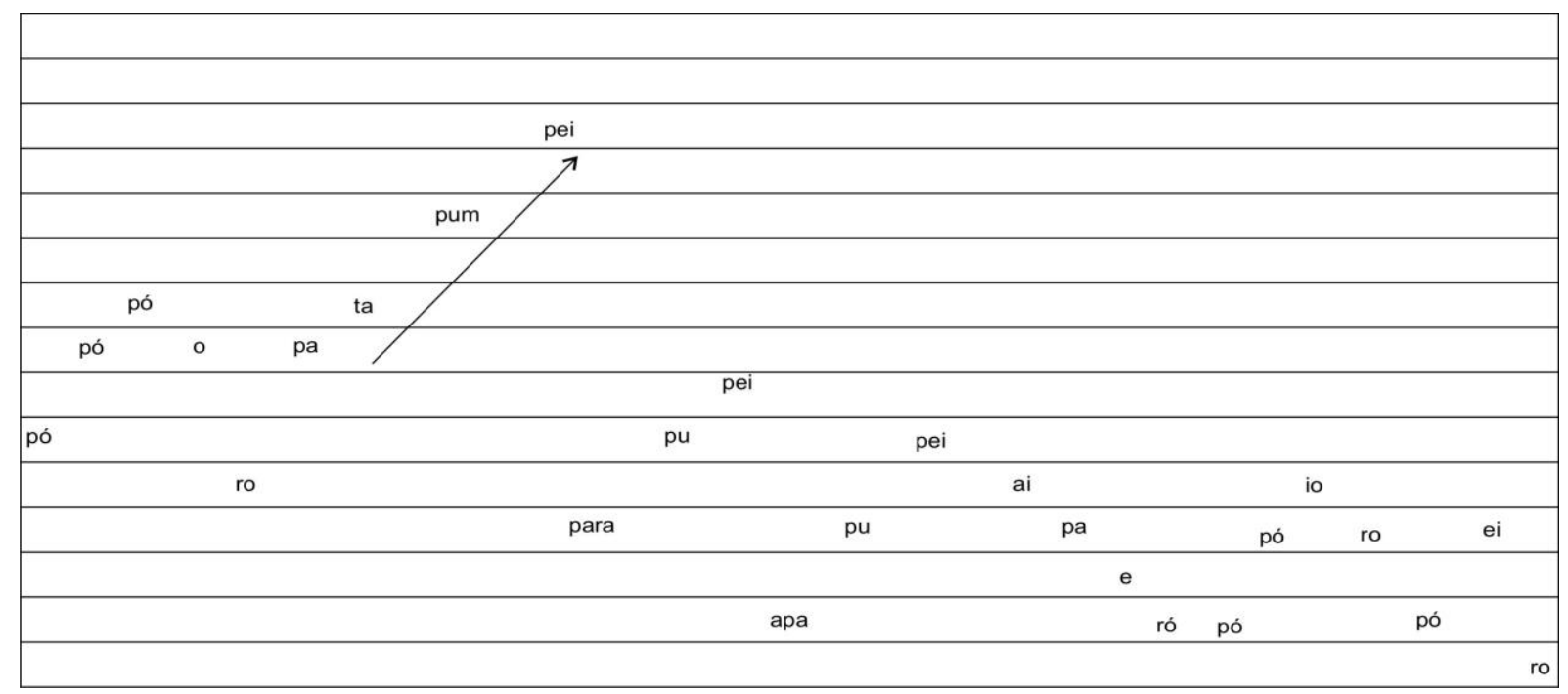

Na primeira exposição da parte A do tema, Gal mostra a melodia praticamente como ela aparece na versão de Ciro Monteiro, a não ser por uma pequena alteração melódica nas frases: "não samba, não mexe/ não bole nem nada". No entanto, já na repetição dessa mesma parte, ela rompe o campo da tessitura, ampliando a melodia em direção ao agudo - "que en_tra no samba" - e recria a articulação rítmica com pequenas ações locais que criam marcas do canto no enunciado, produzindo efeito de proximidade. Essas ações locais são realizadas pela inserção de um breque - "que fica" -; também pela rearticulação rítmica - "parada" -, além da repetição imediata de palavras ou frases: "bole, bole", "por ela, por ela, por ela".

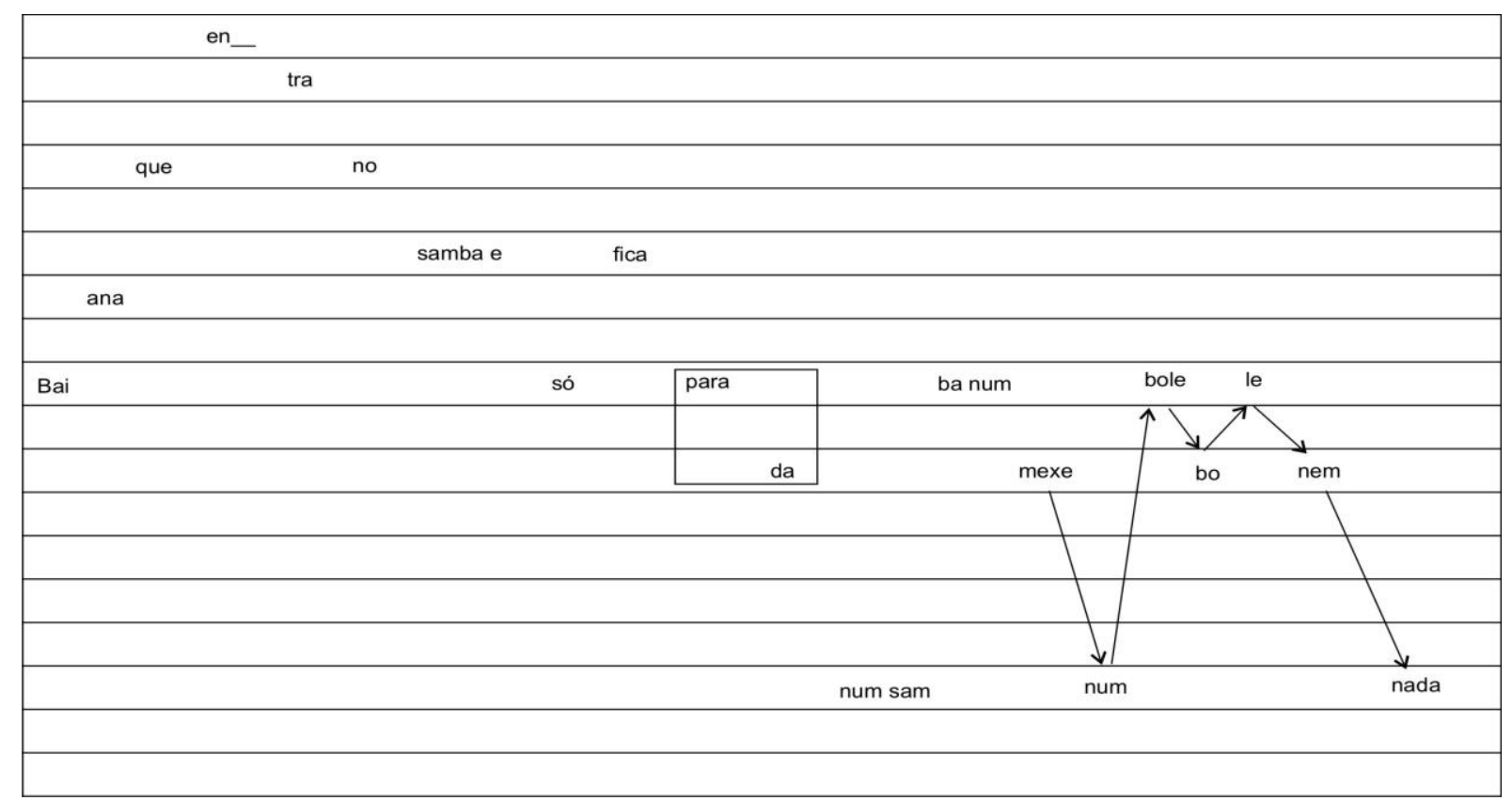




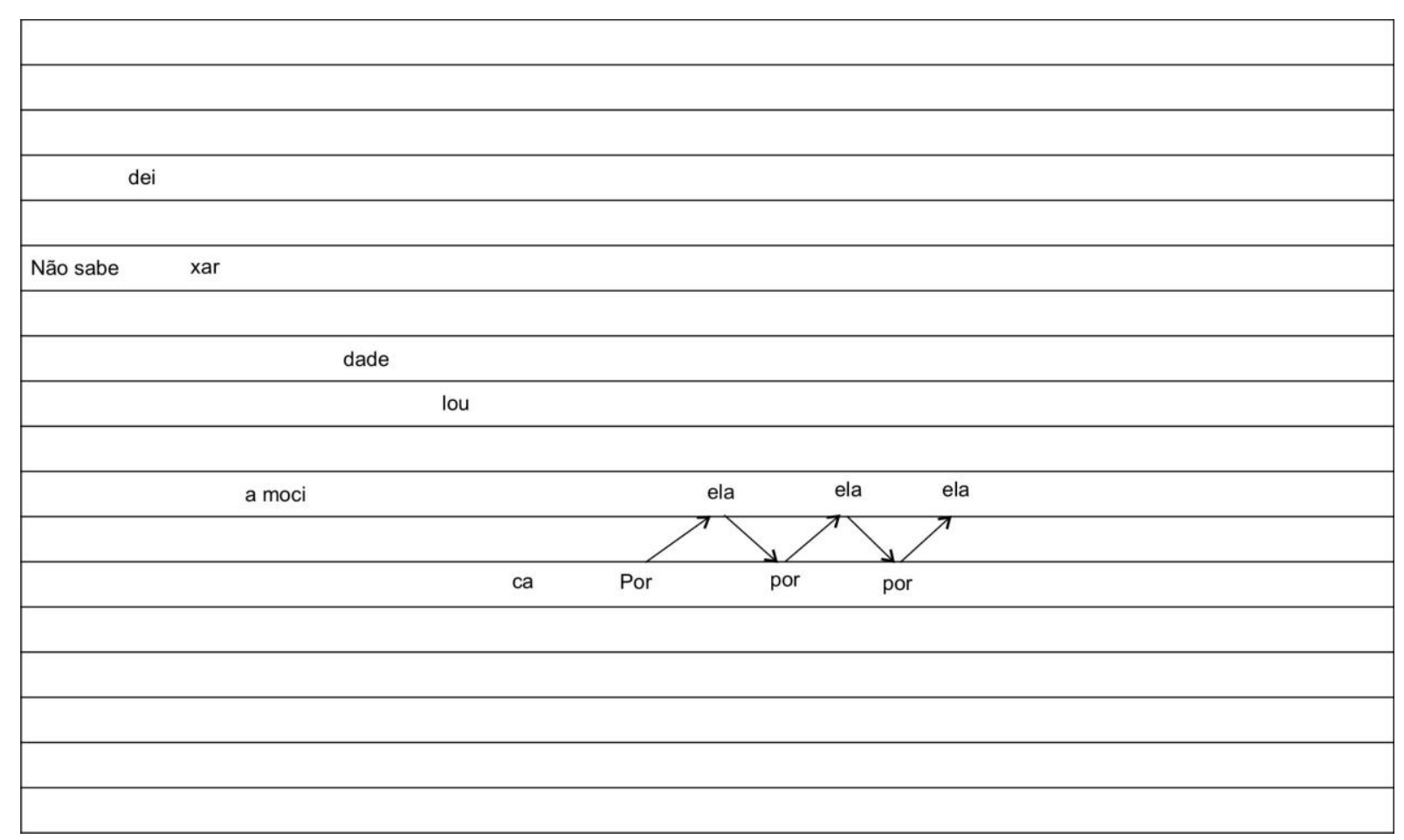

Esses recursos podem enfraquecer o plano de conteúdo linguístico, mas revitalizam o sentido musical e deixam transparecer um sentimento de domínio da melodia pela intérprete, revalorizando os planos de expressão (musical e linguístico). Desta forma, estreitam-se os elos do canto com a canção, posicionando-se a intérprete com mais ênfase no interior do discurso. Essa quase fusão resulta na percepção da cantora como sujeito dessa enunciação e, ao mesmo tempo, como objeto de desejo do ouvinte/espectador. Por esse viés, é possível compreender o tanto de passionalização que a intérprete acrescenta à obra ao estabelecer um liame entre o ouvinte, na condição de sujeito apartado do objeto, e a figura da "moçada" que quer, mas não pode se aliar à baiana ("e deixa a moçada com água na boca"), restando-lhe apenas a sensualidade da própria voz.

Desse ponto em diante, a relação de proximidade não é mais rompida, e a intérprete apresenta-se à vontade para recriar sucessivamente o tema. Ao mesmo tempo, a emissão vocal atinge ressonância alta, com timbre airado. Esses recursos vocais reforçam a ideia de leveza, que é transmitida pela imagem da baiana que sabe sambar e cuja feminilidade confere veracidade ao discurso; ao mesmo tempo, tira a enunciadora da posição de observador para torná-la sujeito da ação. 
Gal apresenta a parte B da composição realizando uma improvisação sobre a melodia, que só em alguns momentos retorna ao tema original, porém sempre entremeada por frases improvisadas. Em seguida, retoma a parte $A$ e, desta vez, já sugere alguma desconstrução da letra, para depois retomar a parte $B$, recortando o fraseado original com improvisações e percussões vocais que deixam clara a intimidade da intérprete com o tema. Estas ações locais cuidam de estabelecer o elo com a melodia original.

$\mathrm{Na}$ quarta exposição da parte A, Gal improvisa livremente sobre a base harmônica e elimina a letra, fazendo uso de silabações que enfatizam o caráter somático da canção. Nesse momento, há uma mudança de significação, pois as ações locais atuam para desconstruir, na canção integral, o elo com a melodia original. Já na quinta exposição de A, ela mantém o comportamento de improvisação, mas começa a reconstruir os elos com a melodia original e a letra, por meio de uma síntese do texto expresso nas frases: "isso não é baiana" e "baiana". Essas mesmas frases constituirão o fio condutor que trará de volta a composição original. Assim, na última exposição da parte $\mathrm{B}$, a realização vocal restaura a letra e remete ao tema musical, mantendo, no entanto, as variações melódicas.

Desse ponto em diante, Gal Costa retoma o tema da introdução, ou seja, reafirma o elo com a Bossa Nova ao citar "Meditação", para em seguida romper novamente o campo melódico com improvisações sobre a base harmônica da introdução. E, para finalizar, recupera mais uma vez o tema da introdução com uma desaceleração brusca no andamento, que imprime de novo a expressão passional da interpretação. Isso porque, se o espaço aberto às improvisações silábicas ampliou o elo somático, ao restaurar a passionalização por meio da desaceleração, Gal recoloca no centro da performance o exercício da sedução, que evidencia a distância entre sujeito e objeto, fazendo emergir no ouvinte o desejo de conjunção. 


\section{Conclusão}

As diferentes marcas da enunciação, impressas pelas interpretações no enunciado, conferem a essas duas gravações efeitos diversos de proximidade. A gravação realizada por Ciro Monteiro já carrega alguns elementos da modernidade da época que aparecem na canção popular pelo universo do samba. São eles: a inserção de quase fala presentes nos comentários realizados pelo intérprete no decorrer da canção - "Eh eh meu senhor" -, a ausência de vibrato e a manipulação do timbre, produzindo um escurecimento em alguns finais de frases, elementos que, como já apontamos, enfatizam a percepção de um enunciador masculino seduzido pela figura da baiana. Seus recortes na articulação rítmica sugerem também sua cumplicidade ante os estímulos somáticos impressos pelo gênero e a valorização dos aspectos positivos, referentes à verdadeira baiana, descritos na letra. Tudo na interpretação revela o estado eufórico do enunciador e a forte conjunção que parece se estabelecer pelo olhar, visto que o cantor, em diversos momentos, canta como se estivesse descrevendo uma cena em andamento - fato que, aliás, justifica a inserção de comentários como "Salve a Bahia, Senhor!".

A gravação de Gal Costa, por sua vez, pelas escolhas melódicas que ampliam a tessitura original, bem como pelo andamento lento, estabelece um elo mais passional entre melodia e letra. A inserção de silabações em linhas de improvisação e a exploração silábico-musical do texto ("por ela, por ela"; "que bole, bole, da nó nas cadeiras") desviam a atenção do plano de conteúdo e enfatizam o plano de expressão. A sensualização da voz, bem como a própria imagem já consolidada da intérprete, cria uma identificação imediata entre Gal e a verdadeira baiana. A intimidade da realização se completa pelo fato da cantora ser acompanhada por um único instrumento, um violão tocado por ela mesma. Assim, essa imagem solitária, reafirmada pela realização vocal que imprime variações consideráveis à melodia, mostra um componente disfórico na interpretação. Ao mesmo tempo, o exercício da sedução pela intérprete transforma o ouvinte em sujeito, em busca de estabelecer a conjunção com a figura da verdadeira baiana realizada pela cantora. 


\section{5 "LÁBIOS QUE BEIJEI" \\ (J. Cascata e Leonel Azevedo)}

A valsa "Lábios que Beijei", uma composição de J. Cascata e Leonel Azevedo, tornou-se um clássico da canção popular na voz de Orlando Silva. Inicialmente, foi composta para integrar o repertório do programa Hora Sertaneja, apresentado por Renato Murce na Rádio Philips, do qual os compositores participavam com regularidade. Uma exigência da direção da rádio obrigava a constante apresentação de repertório inédito, o que incitou a dupla a trabalhar em parceria.

Segundo Homem de Mello e Severiano (1997), o ano de 1937 foi pródigo para o gênero valsa e esta canção teria contribuído para firmar Orlando Silva, então com 22 anos de idade, como um dos grandes intérpretes da música popular brasileira. Também segundo os autores, o arranjo criado por Radamés Gnattali, destacando o naipe de cordas, se tornou referência para a gravação desse tipo de repertório.

É possível considerar que essa referência ultrapassou o período em questão, integrando-se à história da nossa canção. Isso pode ser constatado não apenas na regravação da música por Caetano Veloso, na qual se ouve o mesmo tipo de formação presente na gravação original, mas também em gravações de outras valsas, como "Beatriz", realizada por Milton Nascimento e analisada neste trabalho, que resgata o elo com a tradição da valsa brasileira.

\section{"Lábios que Beijei”}

1 Lábios que eu beijei

2 Mãos que eu afaguei

3 Numa noite de luar assim

4 O mar na solidão bramia

$5 \mathrm{E}$ o vento a soluçar pedia

6 Que fosses sincera para mim

7 Nada tu ouviste

$8 \mathrm{E}$ logo partiste 
9 Para os braços de outro amor

10 Eu fiquei chorando

11 Minha mágoa cantando

12 Sou a estátua perenal da dor

13 Passo os dias soluçando com meu pinho

14 Carpindo a minha dor sozinho

15 Sem esperança de vê-la jamais

16 Deus tem compaixão deste infeliz

17 Por que sofrer assim

18 Compadecei-vos de meus ais

19 Tua imagem permanece imaculada

$20 \mathrm{Em}$ minha retina cansada

21 De chorar por teu amor

22 Lábios que beijei

23 Mãos que eu afaguei

24 Volta, dá lenitivo à minha dor

\section{Sobre a canção}

O regime de integração entre melodia e letra é a passionalização. A melodia delineia-se num percurso de 21 semitons, uma extensão bastante pronunciada e mesmo incomum no universo da canção, que exige do intérprete grande capacidade vocal.

A composição está dividida em quatro partes diferentes, e a letra, cuja estrutura e vocabulário remetem aos exageros dramáticos do romantismo, trata da disjunção entre sujeito e objeto e do desejo desesperado daquele para reestabelecer a conjunção. Divide-se em quatro estrofes, que obedecem à seguinte estrutura de rimas: $a a b c c b$. Já no que concerne à forma musical, a estrutura adotada é A A' B B'.

A melodia se desenvolve de maneira idêntica sobre os três primeiros versos das partes $\mathrm{A}$ e A'. Tanto do $3^{\circ}$ para o $4^{\circ}$ verso quanto do $9^{\circ}$ para o $10^{\circ}$, é possível observar um procedimento de soldagem melódica: a nota que finaliza um verso é a mesma que 
inicia o seguinte, compatibilizando a melodia com a expressão de continuidade, seja para invocação da cumplicidade dos elementos da natureza, como ocorre na parte $A$, seja para evidenciar o estado de penúria do sujeito abandonado, como ocorre em $A^{\prime}$.
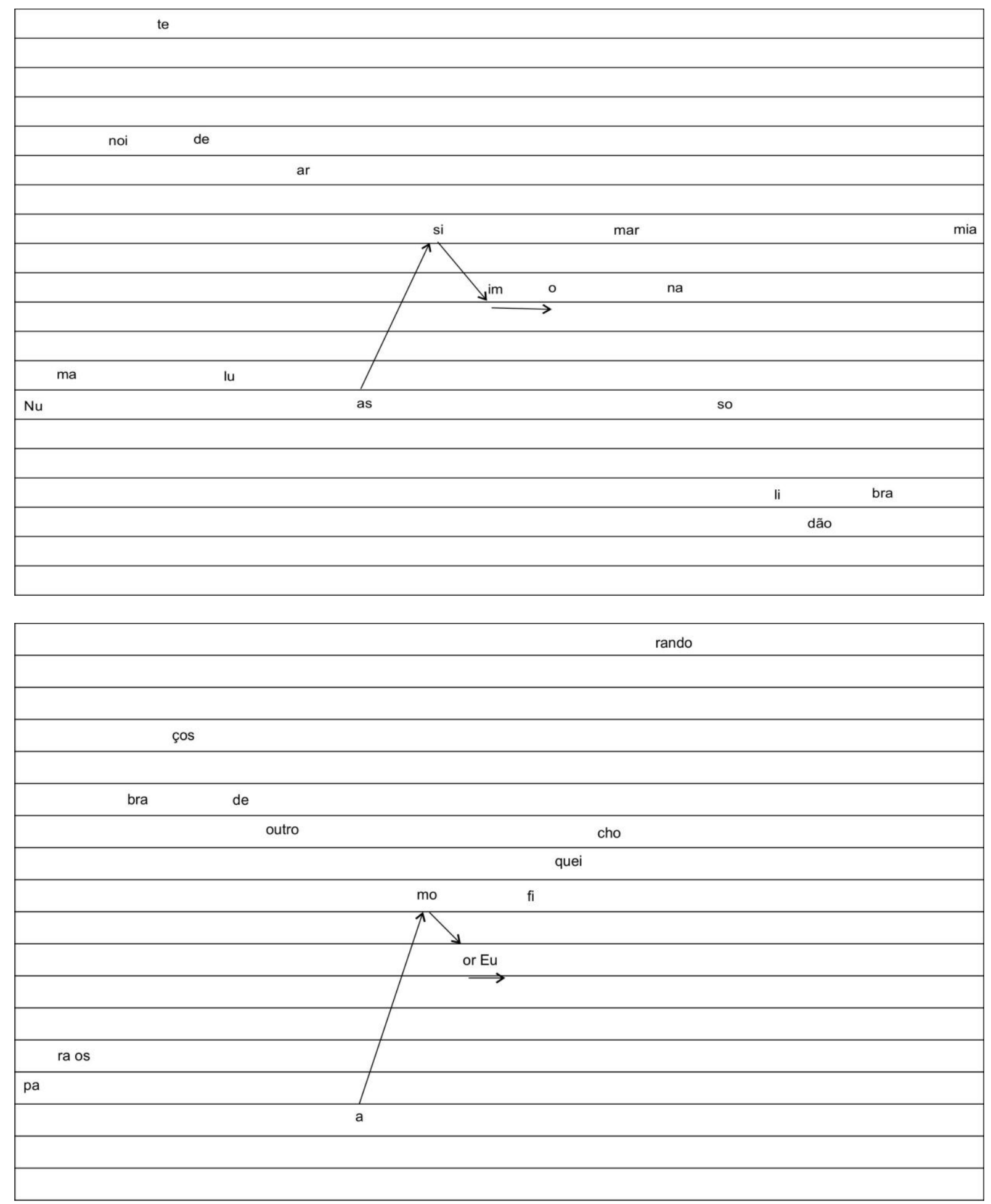
Nos versos 4 e 5, o compositor atribui sentimentos humanos a elementos da natureza, construindo uma paisagem noturna que se torna cúmplice de seu apelo: "O mar na solidão bramia / E o vento a soluçar pedia / Que fosses sincera para mim".

Do ponto de vista melódico-harmônico, a finalização da melodia, que incide sobre o último verso da primeira estrofe, dá-se sobre o segundo grau da tonalidade, sendo harmonizado pelo acorde de dominante. Isso imprime uma tensão melódica que não produz uma sensação conclusiva, de onde advém a necessidade de continuação. Essa não-resolução da melodia espelha o desejo de continuidade expresso no texto: "Que fosses sincera para mim", afirmando um desejo contínuo de lealdade como base da conjunção. No entanto, a continuidade melódica que se processa na parte A' abriga a segunda estrofe da letra, que revela a disjunção: "Nada tu ouviste / E logo partiste / Para os braços de outro amor".

Tudo na letra expressa o caráter breve de permanência da amada - "E logo partiste / Para os braços de outro amor" -, em contraposição à condição extensa de abandono do sujeito/enunciador: "Eu fiquei chorando /Minha mágoa cantando/ Sou a estátua perenal da dor". A melodia que se desenvolve sobre esta última frase descreve uma trajetória que finaliza no primeiro grau da tonalidade, produzindo a sensação de resolução. Desta forma, a condição de sofrimento do enunciador se estabelece como definitiva. E a parte B será dedicada a expressar o estado de disjunção e o sofrimento decorrente do mesmo.

Ocorre na composição uma expansão mais acentuada em direção ao agudo, e o enunciador expõe sua condição solitária e submissa: "Passo os dias soluçando com meu pinho / Carpindo a minha dor sozinho / Sem esperança de vê-la jamais". Ante a constatação de que esse estado não será transformado por ação da amada, resta o apelo à força divina como única alternativa para a transformação da disjunção e do estado passional que o submete. No entanto, a presença da mulher amada é forte o suficiente para retornar com força plena na última estrofe, demonstrando claramente que a disjunção se manifesta de maneira lenta e duradoura por toda canção: "Tua imagem permanece imaculada / Em minha retina cansada / De chorar por teu amor". 


\section{ANÁLISE DO COMPORTAMENTO VOCAL}

\section{Orlando Silva}

Andamento: $104 \mathrm{bpm}$

Tonalidade: $\mathrm{F}$

Tessitura: 21 semitons

Instrumentação: Orquestra Victor Brasileira (piano, clarinete, flauta, violinos, cello, contrabaixo e bateria)

Forma: Introdução A A' B B' A (instrumental) A' (instrumental) B'

Ano: 1937 (canção relançada no CD Revivendo - Orlando Silva - Faixa 8)

Arranjo: Radamés Gnattali

O canto de Orlando Silva, ainda que hoje possa ser visto como preso à referência estética de sua época, revela um refinamento técnico e expressivo que tornou definitiva sua presença, ainda muito jovem, na história das vozes populares no Brasil. Seu fraseado melódico e sua articulação rítmica, bem como o controle de dinâmica, mostram um domínio muito grande do ponto de vista técnico. Ao mesmo tempo, destaca-se uma força interpretativa suportada por esses elementos, os quais justificam sua presença não apenas como demonstração de virtuosismo vocal, mas sim como mediadores de uma força emotiva que se expressa através da voz.

Sua emissão vocal é predominantemente posteriorizada, o que permite antever a ocupação do espaço interno da boca próximo ao palato mole. No entanto, destaca-se a articulação rítmica combinada com a dicção bastante clara, revelando a importância dada ao texto, pelo intérprete, na construção do canto. A ênfase em recursos técnicos, como as apogiaturas, empregadas, por exemplo, sobre as sílabas em negrito, reforça o caráter dramático da interpretação: "Passo os dias soluçando com meu pinho / Deus tem compaixão deste infeliz / Por que sofrer assim".

Em virtude do tipo de colocação vocal, a voz aguda do intérprete apresenta um ligeiro escurecimento no timbre, especialmente nas seguintes terminações: "Sem esperança de vê-la jamais / Compadecei-vos de meus ais / Tua imagem permanece imaculada / Em minha retina cansada / De chorar por teu amor". Estas ações locais 
reforçam o aspecto dramático, que se projeta de forma extensa pela canção, compatibilizando-se com o estado disjunto entre sujeito e objeto.

O canto bastante formal espelha um comportamento de recato compatível com a imagem do cantor na época. Ao mesmo tempo, pelo equilíbrio da emissão e das notas precisas na execução dessa melodia,que apresenta alto grau de complexidade, estabiliza-se uma imagem distanciada em relação ao ouvinte, reforçando a ideia de elevação sublime da voz.

O fraseado privilegia as durações e os elos que reforçam a ideia do estado perene de disjunção em que vive o enunciador.

Orlando Silva valoriza de maneira acentuada o percurso melódico, privilegiando a voz que canta ante a voz que fala. Apenas na última estrofe é possível perceber uma ligeira sobreposição do elemento figurativo da voz, quando, no último verso, a interjeição falada projeta-se sobre a voz cantada: "Volta, dai lenitivo à minha dor".

\section{Caetano Veloso}

Andamento: 92 bpm

Tonalidade: $\mathrm{E}$

Tessitura: 21 semitons

Instrumentação: Introdução A A'B B' Intermezzo (solo de cello) A' B'

Forma: Piano, Violão, Cello, Baixo, Cordas

Ano: 1995 (CD Fina Estampa - Faixa 8)

Arranjo: Jaques Morelembaum

Esta gravação de Caetano Veloso foi realizada ao vivo durante a apresentação do show Fina Estampa, trabalho no qual o cantor resgatava canções do repertório latino-americano, reafirmando os elos com a tradição musical hispânica e brasileira.

Sua interpretação remete diretamente àquela de Orlando Silva, fato que nos mobilizou na realização da análise, visto que demonstrava a clara fusão de um canto pós-Bossa Nova com uma voz que se referencia na tradição da seresta. Ao mesmo tempo, a presença de elementos que, ao longo dos anos, se estabilizaram como 
identificadores do canto de Caetano cuidavam de particularizar esta versão, que revela o componente passional de sua voz. E, segundo o que pudemos observar, esse componente passional marca presença em outras gravações do cantor, mesmo na realização de canções nas quais ocorre um predomínio da tematização, denotando um aspecto profundo de seu canto, o que, no entanto, não será tratado neste trabalho.

A tonalidade escolhida, meio tom abaixo da gravação original, expõe a região médio-grave do intérprete. $\mathrm{O}$ andamento um pouco mais lento amplia o espaço para as durações e para a explanação dos estados passionais que submetem seu canto.

Já no início da gravação, o cantor realiza um portamento lento e descendente sobre a palavra em destaque: "Mãos que eu afaguei". Esse tipo de ornamentação, na qual comparece um certo índice de ruído sonoro na voz, já que é possível perceber uma falha vocal na emissão, é uma marca registrada do canto de Caetano, que curiosamente não se repetirá durante a interpretação. No entanto, ele fará uso de algumas mudanças no padrão de emissão vocal que convocarão a presença da voz de Orlando Silva, reafirmando a ideia de tributo realizado na interpretação.

Podemos afirmar então que, logo de início, Caetano imprime um gesto local que marca sua identidade, mantendo-se depois numa posição livre de gestos que o caracterizem. Apenas fazendo uso do timbre como identificador de sua voz, ele realizará sobre as seguintes frases algumas marcas atenuadas que indicam o tributo a Orlando Silva: "Passo os dias soluçando com meu pinho/ Sem esperança de vê-la jamais / Deus tem compaixão deste infeliz".

Por fim, após o intermezzo instrumental, quando retoma o canto, Caetano amplia o espaço para as já citadas mudanças na emissão que invocarão, agora mais acentuadamente, o cantor reverenciado. Essas mudanças são perceptíveis em: "Eu fiquei chorando /Minha mágoa cantando / Tua imagem permanece imaculada / Em minha retina cansada".

A exemplo do que ocorre na gravação original realizada por Orlando Silva, nesta gravação também predomina a presença da voz cantada; somente no último verso Caetano dá espaço para uma sobreposição da fala sobre o canto, como também ocorre na versão original: "Volta, dá lenitivo à minha dor". No entanto, ainda 
que ocorra o predomínio da voz cantada, dada a presença da Bossa Nova e do canto de João Gilberto como modelos para Caetano, sua emissão é mais objetiva e a presença de vibratos incide prioritariamente nos finais de frase. Mas, embora essa atenuação na emissão de vibratos pudesse mitigar a ênfase dramática da interpretação, isso não ocorre. Ao contrário, o discurso se objetiva e rompe-se a distância entre enunciador e enunciatário.

O canto de Caetano torna cada ouvinte um destinatário de seu apelo. Nesse percurso de aproximação, ele exerce a sedução que desperta no ouvinte o desejo de ser ele próprio o novo objeto capaz de transformar o estado emocional do intérprete/sujeito naquela pequena fração de realidade criada no tempo da canção.

\section{Conclusão}

Ainda que seja possível observar claramente que a versão criada por Caetano Veloso é inspirada naquela realizada por Orlando Silva, rendendo mesmo um tributo a este, os cantores imprimem marcas vocais que particularizam suas respectivas interpretações, além de explicitar uma linha do tempo cujas mudanças estéticas se fazem sentir na voz de um e de outro. Esse dado reafirma a ideia de uma tradição vocal consolidada no âmbito da canção popular; ao mesmo tempo, demonstra que, apesar da forte conexão com a tradição, o intérprete é capaz de apontar um caminho de transformação para essa abordagem vocal.

Ao fazer uso de determinados recursos de emissão e de utilização de vibrato, Caetano convoca a porção tradicional de seu canto e rende homenagem à voz referencial de Orlando Silva. Ao mesmo tempo, ao imprimir um único toque pessoal, como aquele portamento apontado logo no início da gravação ou a ausência de vibrato no decorrer dos fraseados, ele também insere a porção de modernidade que o identifica. Reafirma, desse modo, a existência de um projeto extenso para abordagem vocal que une as duas pontas de um canto configurado pela canção popular no Brasil: aquele ligado à tradição da seresta, no qual predomina a entoação cantada, e outro, cujas raízes estão no samba dos anos 1930, que foi aprofundado pelas releituras de João Gilberto, configurando uma nova sonoridade para a voz popular. 


\subsection{LINDA FLOR (YAYÁ) \\ (Henrique Vogeler, Marques Porto e Luiz Peixoto)}

A canção Linda Flor ou laiá é considerada o primeiro samba-canção da história da música popular brasileira. Ela aparece com essa denominação no disco de Araci Cortes, lançado em 1929, embora a levada ${ }^{19}$ que se pode ouvir remeta mais ao maxixe, antecessor direto do samba, que ao samba-canção da "Era de Ouro" do rádio.

Essa canção recebeu outras letras até chegar a esta final realizada por Luiz Peixoto e cantada por Araci no espetáculo de revista Miss Brasil. Tornou-se uma referência na música popular brasileira e foi regravada inúmeras vezes por diferentes intérpretes ao longo desses mais de oitenta anos.

Seguindo os preceitos estabelecidos e que estão expostos no Capítulo 3 do presente trabalho, escolhemos a gravação realizada por Araci Cortes em 1929 e a feita por Zezé Motta em 1979. Podemos destacar que ambas as intérpretes têm em comum o histórico profissional associado ao teatro. Tanto uma quanto outra são atrizes que se dedicaram ao canto, e não exclusivamente cantoras.

Araci Cortes, uma cantora/atriz do teatro de revista, usava a região aguda de sua voz, como, aliás, acontecia com a maioria das cantoras desse período. No entanto, articulava os fonemas de maneira a privilegiar a inteligibilidade do texto. Assim, embora atuasse numa região da voz bastante distante da fala, é possível observar que, em diversos momentos, ela enfatizava o aspecto entoativo, falado, em detrimento do que se poderia chamar de "canto puro" (linha melódica estritamente musical). No cantar de Araci Cortes, essa expressão vocal é tratada de modo a valorizar o componente linguístico, sonoro/rítmico da palavra, e também a expressão emotiva do texto, sob influência do referencial estético vocal vigente no período.

\footnotetext{
${ }^{19}$ Comportamento rítmico dos instrumentos acompanhadores que indicam o gênero musical. Por exemplo, levada de samba, levada de baião, etc.
} 
A outra gravação, realizada por Zezé Motta em 1979, ou seja, cinquenta anos depois, já encontra as vozes femininas explorando regiões mais graves da tessitura. Podemos acrescentar que esse processo de rebaixamento das tessituras, tanto nas vozes femininas quanto nas masculinas, ocorreu na canção popular brasileira a partir de meados dos anos 1940, quando o samba-canção ganhou espaço no mercado fonográfico.

A ênfase na perda amorosa e o uso de referenciais próximos à fala permitiam uma abordagem mais intimista, revelando outro viés para a expressão dramática, justificando, por isso mesmo, o rebaixamento das vozes para que se adequassem ao discurso menos eloquente e mais próximo do ouvinte.

\section{Linda Flor (Henrique Vogeler, Marques Porto e Luiz Peixoto)}

1 Ai, loiô, eu nasci pra sofrê

2 Fui olhá pra você

3 Meu zoinho fechô

4 E quando o zoio eu abri

5 Quis gritá, quis fugi

6 Mas você, eu não sei por que

7 Você me chamou

$8 \mathrm{Ai}$, loiô, tenha pena de mim

9 Meu Senhô do Bonfim

10 Pode inté se zangá

11 Se ele um dia soubé

12 Que você é que é

13 O loiô de laiá

14 Chorei toda noite, pensei

15 Nos beijos de amor que te dei

16 loiô, meu benzinho do meu coração

17 Me leva pra casa, me deixa mais não

18 Chorei toda noite, pensei 
19 Nos beijos de amor que te dei

20 loiô, meu benzinho do meu coração

21 Me leva pra casa, me deixa mais não

\section{Sobre a canção}

A letra da canção trata da impossibilidade da realização amorosa, configurando, por todo o seu desenvolvimento, a distância entre sujeito e objeto, que se expressa na parte musical por verticalização e expansão da melodia. Esta se desenvolve numa tessitura de 18 semitons, compreendendo três partes ( $A, A^{\prime}$ e $\left.B\right)$ do ponto de vista musical, todas no modo maior. Ocorre, no entanto, uma modulação de uma $5^{\text {a }}$ justa ascendente, na qual se realiza a parte B. Essa modulação reflete internamente o aspecto central da canção, cujo modelo de integração entre melodia e letra é a passionalização. Assim, embora tenhamos uma parte B pouco desenvolvida, por ocorrer numa região mais aguda que as partes A e A', preserva a sensação de distância projetada pela melodia inicial, reiterando a trajetória percorrida pelo sujeito para estabelecer a conjunção com o objeto ou com o próprio desejo expresso na narrativa. Essa mesma parte não se desdobra em novas ideias melódicas, atuando como um pequeno desenvolvimento que pede a volta da parte $A$.

O texto mostra um actante em tripla função. Ioiô é ao mesmo tempo o destinador, que por meio da sedução e sem estar efetivamente presente faz que o destinatário queira e se entregue à paixão. Desta forma, ele é também o objeto. Porém, visto que a enunciadora gostaria de se libertar da condição de amante - "E quando o zoio eu abri/ quis gritá quis fugi" -, mas não consegue por estar submetida à sedução exercida por ele - "mas você, eu não sei por que você me chamou" -, podemos olhar para o destinatário também como antissujeito de uma narrativa subjacente.

Desde a frase de abertura, a personagem central se rende a uma condição inata: "Eu nasci pra sofrer". A cifra tensiva identificada aqui mostra o reconhecimento de uma condição natural extensa que vai nortear a vida da personagem descrita pela canção. Mas se esta cifra indica uma previsível e duradoura disjunção, o texto, especialmente 
na parte $B$, revela por sua vez o desejo de conjunção inerente a toda canção de amor: "Me leva pra casa, me deixa mais não".

Como toda melodia que sugere um tratamento passional, esta também se pauta pelas expressivas durações vocálicas, que Ihe impõem uma evolução lenta, pela expansão "vertical" num generoso campo de tessitura e pelos contornos governados por estágios do canto nas notas mais longas. Tudo isso conduzido pelas diretrizes básicas das entoações lingüísticas que têm no movimento descendente associado à asseveração um núcleo figurativo (porque recria a inflexão da fala) de sentido, perante o qual as demais curvas se organizam. (Tatit, 2004)

A parte A da melodia expande-se pelo campo da tessitura. Os movimentos ascendentes são compensados pelos descensos e a chegada às regiões mais agudas se dá de forma gradual.

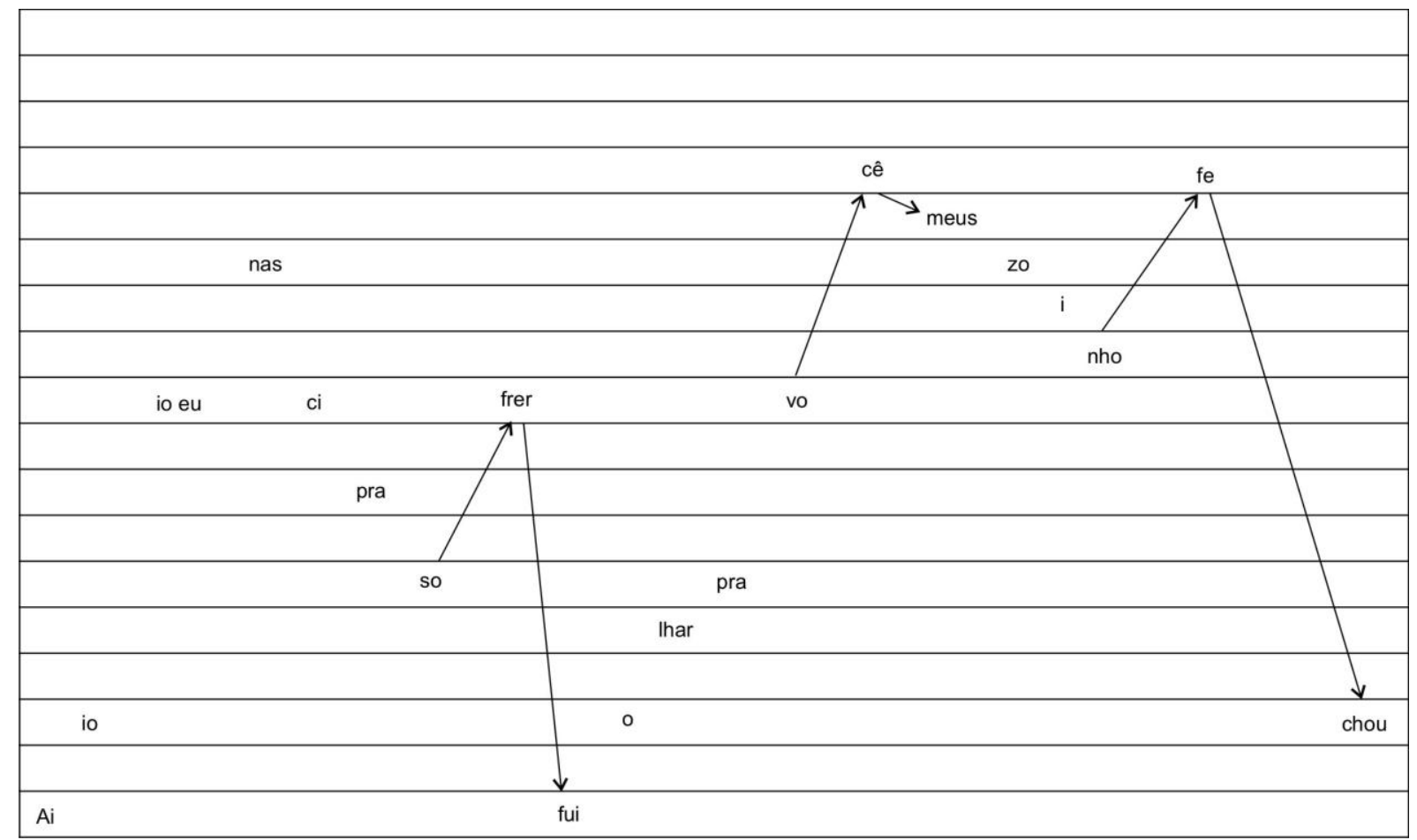

.No início do verso número 4 - "E quando os zóio eu abri" - ocorre, no entanto, uma transposição de registro que desloca toda melodia restante para uma região ainda mais aguda. 


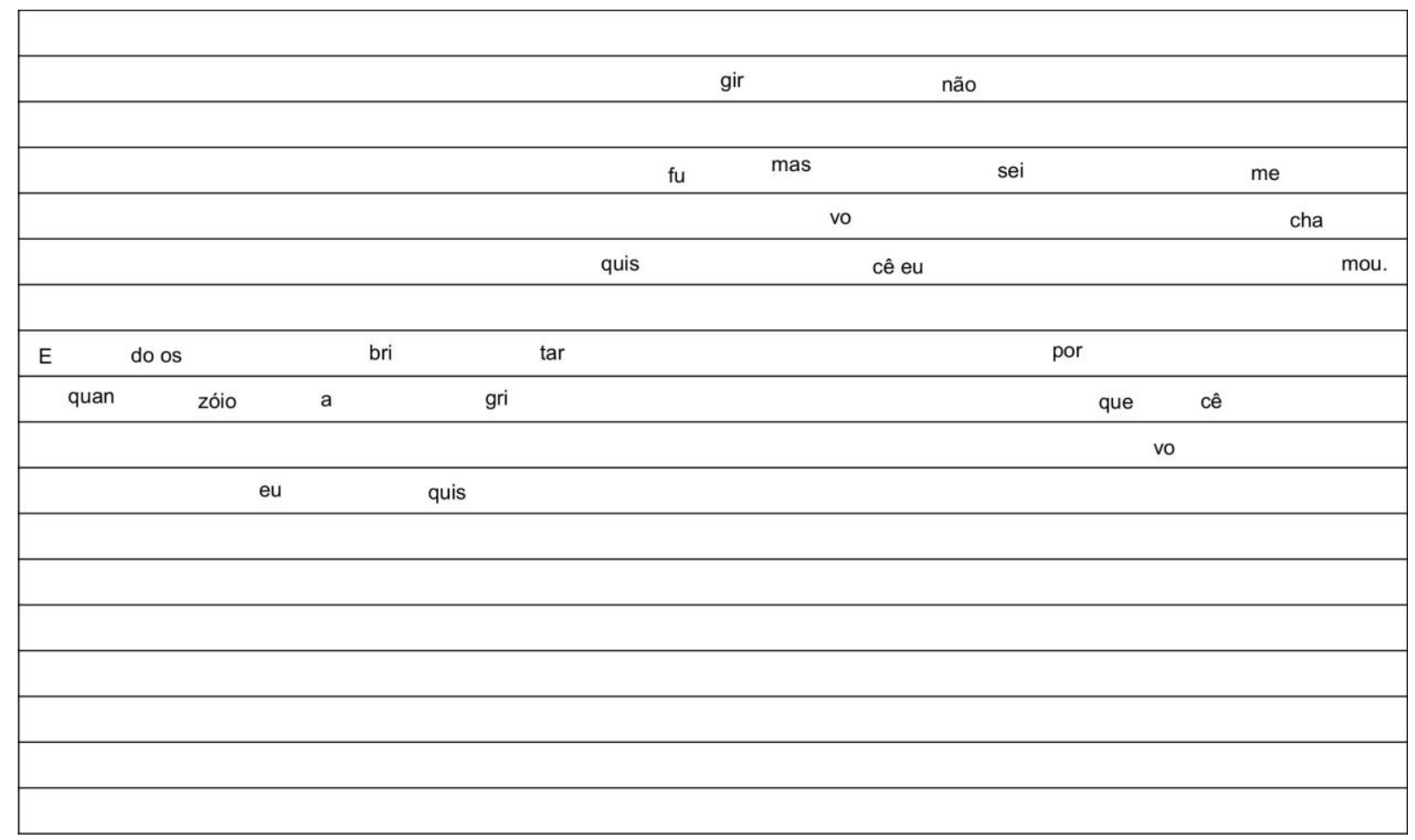

Esse movimento inicial já define a passionalização como projeto de integração entre melodia e letra, reiterando o estado de disjunção entre sujeito e objeto.

Na parte A', que tem início no verso de número 8 - "Ai, loiô tenha pena de mim" essa característica é reiterada pelo prolongamento que ocorre sobre o verso de número 10 - "pode inté__se zangá_" -, seguido do ponto culminante da melodia, expresso na frase: "E se ele um dia soubé...".

Na parte B da canção ocorre uma modulação ascendente, como já observamos. Embora esta ocorrência produza uma sensação de agudização, ela se desenvolve acentuadamente por descendências, criando de certa maneira uma contraposição aos movimentos realizados nas partes A e A'.

A melodia concisa não apresenta desdobramentos e justifica sua presença apenas como gancho para o retorno à primeira parte. Assim, fica claro que a disjunção presente na canção é o elemento norteador e preponderante do desenvolvimento melódico. A vivência da disjunção pelo sujeito, elemento que justifica a existência da canção, é mais forte que o desejo de conjunção. 


\section{Análise do comportamento vocal}

"Além de cantar, o intérprete sempre diz alguma coisa, revela seus sentimentos, suas impressões, ou, no mínimo, envia um recado aos ouvintes."

(LOPES \& TATIT, 2008)

\section{Araci Cortes}

Andamento: 78 bpm

Tonalidade: Ab (lá bemol maior)

Tessitura: 18 semitons

Instrumentação: Introdução A A'B B A A'B (instrumental)B (vocal) Coda

Ano: 1929 (LP Araci Cortes, Funarte - fonograma original inserido no disco-documento sobre sua carreira, lançado em 1984 - Faixa 2-A)

A gravação de Araci Cortes, a primeira desta composição cuja letra é de Luiz Peixoto, mostra uma enunciadora frágil, brejeira, identificada com uma figura feminina submissa. A tonalidade escolhida ( $A b)$ expõe a região extremo-aguda da tessitura da intérprete e cria um simulacro de fragilidade feminina quase caricatural, compatível com a época. A emissão vocal nessa região exige um alto padrão de tensão nas pregas vocais, e esta tensão pode produzir na escuta os efeitos da passionalização descritos na letra, revelando uma enunciadora submissa e sujeita à ação do destinador. Ainda por ação desta mesma tensão nas pregas vocais, a voz resulta sem nenhuma presença de ar, além de mostrar uma ressonância bastante frontalizada, que define um timbre metalizado também identificado com a imagem feminina.

Na gravação de Araci Cortes, a utilização do vibrato nos finais de frase se faz de acordo com as marcas da passionalização. Desta forma, em toda a parte $A$, na qual essa passionalização se expressa mais claramente, a intérprete enfatiza o aspecto cantado da emissão e, por consequência, valoriza as notas longas, com a presença do vibrato em todas as terminações. Já na parte $B$, em que o desenvolvimento melódico é mais concentrado, com pouca expansão do campo da tessitura, destaca-se o aspecto 
entoativo, com encurtamento das durações e ênfase na inflexão de fala. Assim, as alterações da voz reforçam essa alternância, ora valorizando aspectos relativos ao prolongamento das durações e a ênfase dramática, ora valorizando os ataques rítmicos e os apelos somáticos.

Em se tratando de articulação rítmica, a escolha de um andamento rápido faz que a cantora articule os fonemas de maneira breve, sem grandes prolongamentos, a não ser em alguns finais de frase, como já observamos. Esse dado, que compatibiliza a voz com um aspecto mais tematizado, seria ligeiramente compensado pela escolha da tonalidade, garantindo a presença de notas extremamente agudas, que gerariam, assim, uma percepção da disjunção tratada na letra. Mas a ênfase no aspecto rítmico, no caso desta gravação, garante que a expressão do desejo de conjunção seja maior que a vivência da disjunção, tratada mais longamente na composição, mostrando desta maneira a expressão de um desejo da intérprete exposto no plano da expressão realizado pela voz.

\section{Zezé Motta}

Andamento: 66 bpm

Tonalidade: D

Tessitura: 18 semitons

Instrumentação: violão de 7 cordas, flauta, percussão, baixo, teclado, vocal, cavaquinho Forma: Introdução A A'B B Coda (improvisação vocal)

Ano: 1979 (LP Negritude - Faixa 5-B)

Zezé Motta optou pela tonalidade de $D$ (ré maior) e expôs a região médio-grave de sua voz. Se no caso da primeira gravação aqui analisada a opção pela região vocal aguda cria um simulacro de fragilidade para o enunciador, neste segundo caso essa fragilidade dá lugar à força e à sensualidade, sem reduzir em nada os desejos contraditórios de conjunção e disjunção, mas expressando subliminarmente sua capacidade de ruptura com essa condição. Há um distensionamento característico dessa região da voz que transmite força e segurança emocional. O timbre escuro, não só em 
virtude do registro grave, mas também pelo tipo de emissão mais posteriorizada, ${ }^{20}$ evidencia a presença de harmônicos graves, corroborando essa mesma imagem de força e segurança. Nesse tipo de emissão, a percepção da massa de ar dentro da boca é bastante definida, e o escurecimento do timbre resulta da ocupação de um espaço mais amplo e próximo ao palato mole.

Quanto à ênfase dramática, ela não se dá pela presença carregada de vibratos, que estão presentes de maneira sutil nos finais de frase. $O$ aspecto entoativo compõe o elemento profundo de toda a interpretação. Ou seja, embora apresente uma emissão vocal bastante musicalizada, a intérprete não se distancia dos conteúdos expressos pelo texto e valoriza a junção de melodia e letra. É possível constatar que esse comportamento vocal, no que tange tanto ao grau de utilização de vibrato quanto à presença subjacente da entoação, tornou-se referência na canção brasileira a partir da Bossa Nova.

O tempo que separa uma gravação da outra permite que a segunda incorpore alguns elementos na realização vocal que se consolidaram na música popular brasileira após os anos 1960. Neste caso, é importante destacar o papel do arranjo, que aqui é tratado não apenas como a organização dos elementos acompanhadores, mas também como organizador desses elementos para reiterar as significações expressas pela voz da solista. Temos então, nesta gravação, a presença de um coro feminino que aparece na primeira exposição da parte $A$, momento em que se revela, como vimos anteriormente, a síntese passional que se desenvolverá ao longo do tema. Esse coro, por atuar em região aguda, estabelece uma contraposição com a voz da solista, criando um elo com a estética da voz no início do século XX. A intenção do coro é reforçada quando este adota uma vocalização carregada de vibrato e em escala ascendente. Desta maneira, faz surgir dentro do arranjo uma imagem feminina fragilizada, que subjaz à voz principal.

Outra atitude vocal diferenciada diz respeito à utilização instrumental da voz que ocorre no final do arranjo, quando a solista faz uso de algumas silabações, carregadas de

\footnotetext{
${ }^{20}$ Emissão com uma concentração da massa de ar na região próxima ao palato mole. Por ocupar um espaço interno maior, viabiliza também uma projeção mais acentuada de harmônicos graves, que tornam o corpo da voz mais denso e permitem uma timbragem mais escura.
} 
intenção linguística, que criam significações com a mescla de recursos entoativos de canto e de quase fala.

A escolha do andamento lento permite, por sua vez, que a articulação rítmica se realize de modo a valorizar o tempo interno de cada sílaba e, com isso, evidencie a trajetória percorrida, enfatizando a percepção do campo da tessitura, elemento esse que caracteriza a passionalização, como já vimos.

Outro elemento a ser destacado no arranjo explora, nas partes A e A' da composição, uma levada percussiva tercinada, que se sobrepõe à levada em 4, produzindo um efeito dançante e que remete diretamente à cultura negra. Com a mudança de levada para um samba-choro na parte $B$, sugere-se a miscigenação presente na formação da cultura e da canção brasileira. Esse entendimento pode se dar pelo fato de a letra da canção retratar o sentimento de amor de uma escrava ou ex-escrava em relação ao seu senhor, já que os termos loiô e laiá eram empregados pelos escravos para se referirem ao Sinhô e à Sinhá. Sendo assim, uma alteração no plano da expressão do discurso musical termina por significar algo do plano do conteúdo do texto poético.

\section{Conclusão}

Podemos concluir que, nas duas gravações, as enunciadoras são feitas destinatárias de loiô, que imprime pela sedução as competências modais que possibilitam a ambas quererem se entregar à paixão. O conteúdo emotivo que transparece pelas vozes mostra, porém, que elas vivenciam e realizam isso de maneiras diferentes. Do ponto de vista técnico-vocal, podemos identificar em cada intérprete elementos específicos de utilização da voz, a começar pelos níveis de tensão muscular opostos, que constroem significações também muito diferentes.

No caso de Araci Cortes, a tessitura extremamente aguda traduz um alto nível de tensão, revelando, como foi dito na análise, um componente feminino submetido à ação do destinador. Embora a realização musical aconteça em andamento mais acelerado, o componente vocal denota uma fragilidade e traduz uma enunciadora modalizada pelo /ser/, e por isso mesmo incapaz de romper o ciclo da paixão que a submete. 
Já na gravação de Zezé Motta, o uso da região grave da voz produz uma sensação oposta. Ou seja, a tensão atenuada permite antever a força psíquica, que traduz uma carga interpretativa e revela, pelos componentes da voz, uma enunciadora modalizada pelo /fazer/. Deste modo, embora ela também esteja submetida pela paixão, subjaz uma percepção de que este ciclo pode ser rompido.

$\mathrm{Na}$ letra, em ambas as gravações, a enunciadora aparece temerosa diante da possibilidade de ser sancionada pelo santo: "Meu Sinhô do Bonfim pode inté se zangar". Podemos ler esse medo adequado à cada interpretação e a cada universo étnico, visto que o Senhor do Bonfim é um santo sincrético por natureza. Na Bahia, o dia dedicado a ele é celebrado tanto por católicos quanto por praticantes do Candomblé, que o relacionam a Oxalá.

$\mathrm{Na}$ leitura feita por Araci Cortes, detectamos esse desejo contraditório de conjunção e disjunção que submete nossa enunciadora a expressar até mesmo o medo de ser castigada pelo santo, como reflexo de submissão a uma ordem social ainda escravocrata. Já na gravação de Zezé Motta, a temeridade ao santo também se expressa, embora submetida a outra ordem moral religiosa: alguns elementos do arranjo, que imprimem uma condução rítmica similar a batidas de pontos ${ }^{21}$, reiteram essa presença.

Na primeira leitura, o santo seria o responsável pela sanção aplicada caso a enunciadora continuasse a subverter a ordem moral por conta da entrega à paixão proibida a um homem branco, casado e pertencente a uma outra classe social. Já na segunda leitura, a sanção se daria pelo envolvimento com um homem branco e opressor.

Curiosamente, se dentro do universo da canção popular brasileira é recorrente que a melodia atinja o ápice quando o texto faz referência direta à disjunção amorosa, neste caso, o ápice da melodia que ocorre na parte A' acontece quando se expressa o temor à reação do santo se ele vier a descobrir quem é o loiô: "E se ele um dia souber..." Desta forma, é possível compreender que há uma ética religiosa que age como um grande destinador.

\footnotetext{
${ }^{21}$ Nos rituais afro-brasileiros, cântico que identifica ou invoca um orixá.
} 


\section{7 "NA BATUCADA DA VIDA" (Ary Barroso e Luiz Peixoto)}

"Na Batucada da Vida", de Ary Barroso e Luiz Peixoto, foi composta para uma revista musical, em que era interpretada por Araci Cortes, sob o título de "A Canção da Enjeitada". A primeira gravação, no entanto, foi realizada pela cantora Carmen Miranda em 1934, acompanhada pelo grupo Diabos do Céu. Consta do encarte do CD, lançado pelo selo Revivendo, que Carmen, com dificuldade para gravar o samba, teria reclamado a Ary Barroso: "Também, você vai fazer um samba que ocupa da primeira à última nota do piano! Isto nem é samba: é uma escala musical!". Por essa afirmação já seria possível antever qual o modelo de integração entre melodia e letra selecionado pelo compositor.

Embora ao longo desses mais de setenta anos "Na Batucada da Vida" tenha sido regravada inúmeras vezes por cantores como Dircinha Batista, Elizete Cardoso, Miúcha e Joyce, entre outros, as releituras feitas por Elis Regina, em 1974, e Ná Ozzetti, em 2009, estabelecem novos referenciais para a percepção da interferência do intérprete na elucidação de certos componentes da obra, delineando outros aspectos da tensividade inscrita originalmente na canção ou mesmo criada pela versão do intérprete.

Desde a primeira gravação, em 1934, a música foi classificada como sambacanção, gênero que se transformaria consideravelmente a partir da metade dos anos 1940, sofrendo influência direta do bolero e também da canção popular norteamericana, veiculada, sobretudo, pelo cinema. Após esse período, os andamentos tornaram-se mais lentos e a contribuição harmônica fez-se mais sofisticada, incluindo tensões e extensões dos acordes, substituições harmônicas, etc., que passaram a fazer parte da música popular brasileira, culminando com a Bossa Nova a partir de 1958.

Dentro do universo do samba, até a metade dos anos 1940 o tratamento dado às tragédias pessoais desenvolvia-se mais comumente por meio de uma abordagem cômica e irônica do que propriamente trágica, como se pode constatar nas composições: "Tu Qué Tomá meu Home", de Ary Barroso e Olegário Mariano, "Gago Apaixonado", "Amor de Parceria" e "O Maior Castigo que eu te Dou", de Noel Rosa, "Inimigo do Batente", de Wilson Batista e Germano Augusto, "Não Quero Saber Mais 
Dela", de Sinhô, "Gavião Calçudo", de Pixinguinha e Cícero da Almeida, "Se Você Jurar", de Ismael Silva, Nilton Bastos e Francisco Alves, "Só Dando com uma Pedra Nela", de Lamartine Babo, "Abre a Janela", de Arlindo Marques Junior e Roberto Roberti, e "Camisa Listrada", de Assis Valente, para citar alguns poucos exemplos.

A questão da passionalidade se acentua de modo considerável a partir do início da década de 1950, dando origem à chamada "música de fossa". Analisando o perfil vocal dos cantores surgidos nesse período - entre eles Dick Farney, Nora Ney, Ângela Maria, Cauby Peixoto, Lucio Alves, Maysa e Dolores Duran -, é possível notar que ocorreu um rebaixamento nas tessituras vocais. Ou seja, abriu-se um espaço maior para cantores de vozes graves ou médio-graves, sendo esse fato notório principalmente para as vozes femininas, que atuavam, até então, em região aguda.

De imediato, isso nos possibilita compreender as diferenças entre as versões dadas por Carmen Miranda e Elis Regina, já que é possível detectar que o intérprete reflete no canto elementos presentes nos referenciais estéticos que vigoram em seu tempo. $E$, ainda que ele transforme elementos e estabeleça novos parâmetros, deixa transparecer essas referências em suas realizações.

\section{Na Batucada da Vida (Ary Barroso e Luiz Peixoto)}

1 No dia em que apareci no mundo

2 Juntou uma porção de vagabundo, da orgia

3 De noite teve choro e batucada

4 Que acabou de madrugada

5 Em grossa pancadaria

6 Depois do meu batismo de fumaça

7 Mamei um litro e meio de cachaça, bem puxado

$8 \mathrm{E}$ fui adormecer como um despacho

9 Deitadinha no capacho

$10 \mathrm{Na}$ porta dos enjeitados 
11 Cresci, olhando a vida sem malícia

12 Quando um cabo de polícia

13 Despertou meu coração

14 Mas como eu fui pra ele muito boa

15 Me soltou na rua à toa

16 Desprezada como um cão

17 Agora que eu sou mesmo da virada

$18 \mathrm{E}$ que não tenho nada, nada

19 E de Deus fui esquecida

20 Irei cada vez mais me esmolambando

21 Seguirei sempre sambando

$22 \mathrm{Na}$ batucada da vida

\section{Sobre a canção}

O modelo central de integração entre melodia e letra é a passionalização. No entanto, a tematização aparece como modelo auxiliar, atenuando de certa forma a percepção da expansão pelo campo da tessitura. Outro elemento que contribui para uma percepção atenuada do conteúdo passional é o andamento acelerado, presente na primeira gravação realizada pela cantora Carmen Miranda e que é, provavelmente, o andamento original.

Os conteúdos disfóricos da letra são corroborados pela melodia, que se expande em movimento ascendente nas duas primeiras frases da parte $A$, prosseguindo em movimentos mistos (descendente/ascendente) nas outras três frases que complementam a estrofe. O encaminhamento em direção ao grave reforça os conteúdos asseverativos, enquanto as terminações agudas, atingidas por gradação ascendente, reforçam de maneira atenuada a percepção do percurso: De noite teve choro e batucada / Que acabou de madrugada / Em grossa pancadaria. 

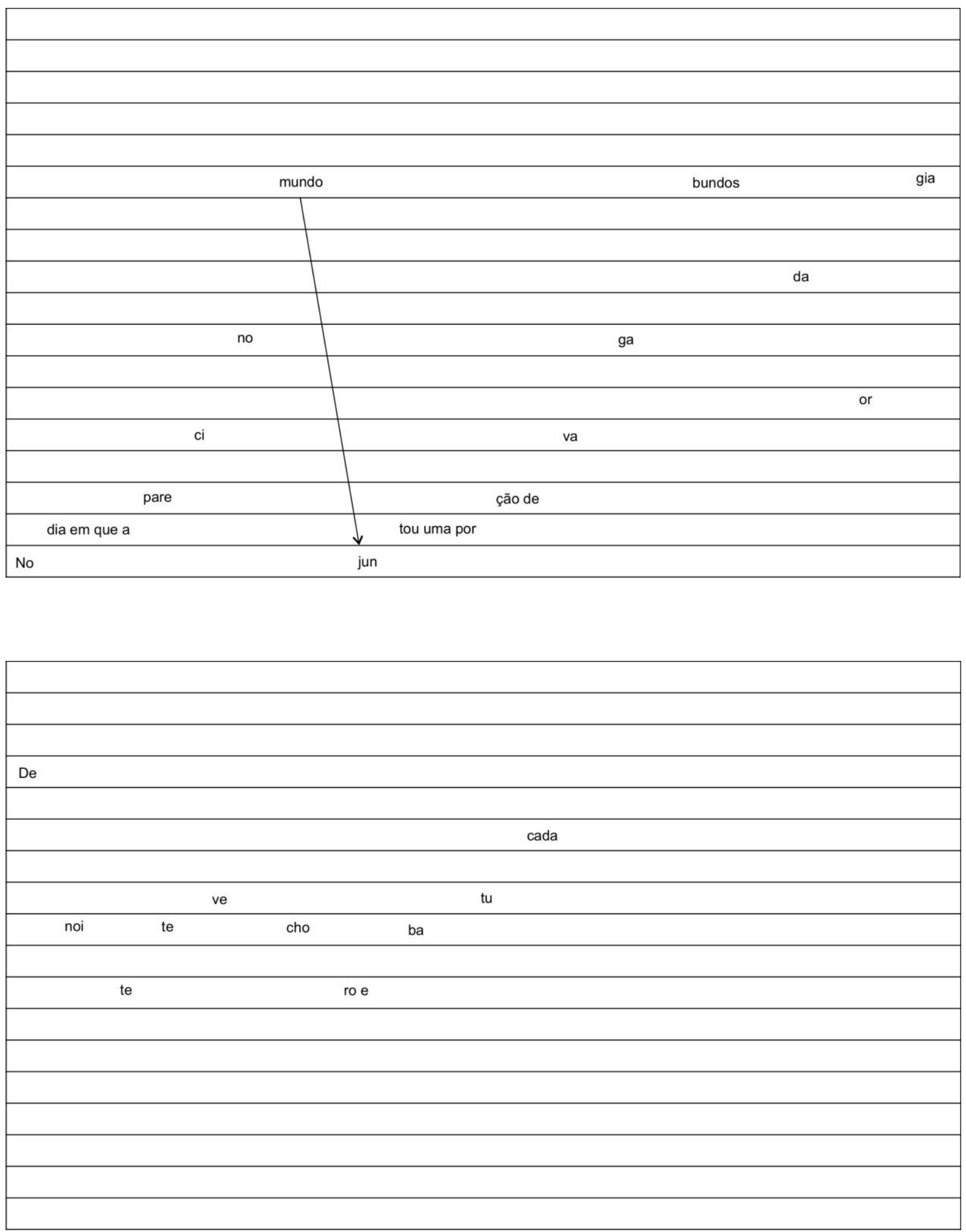


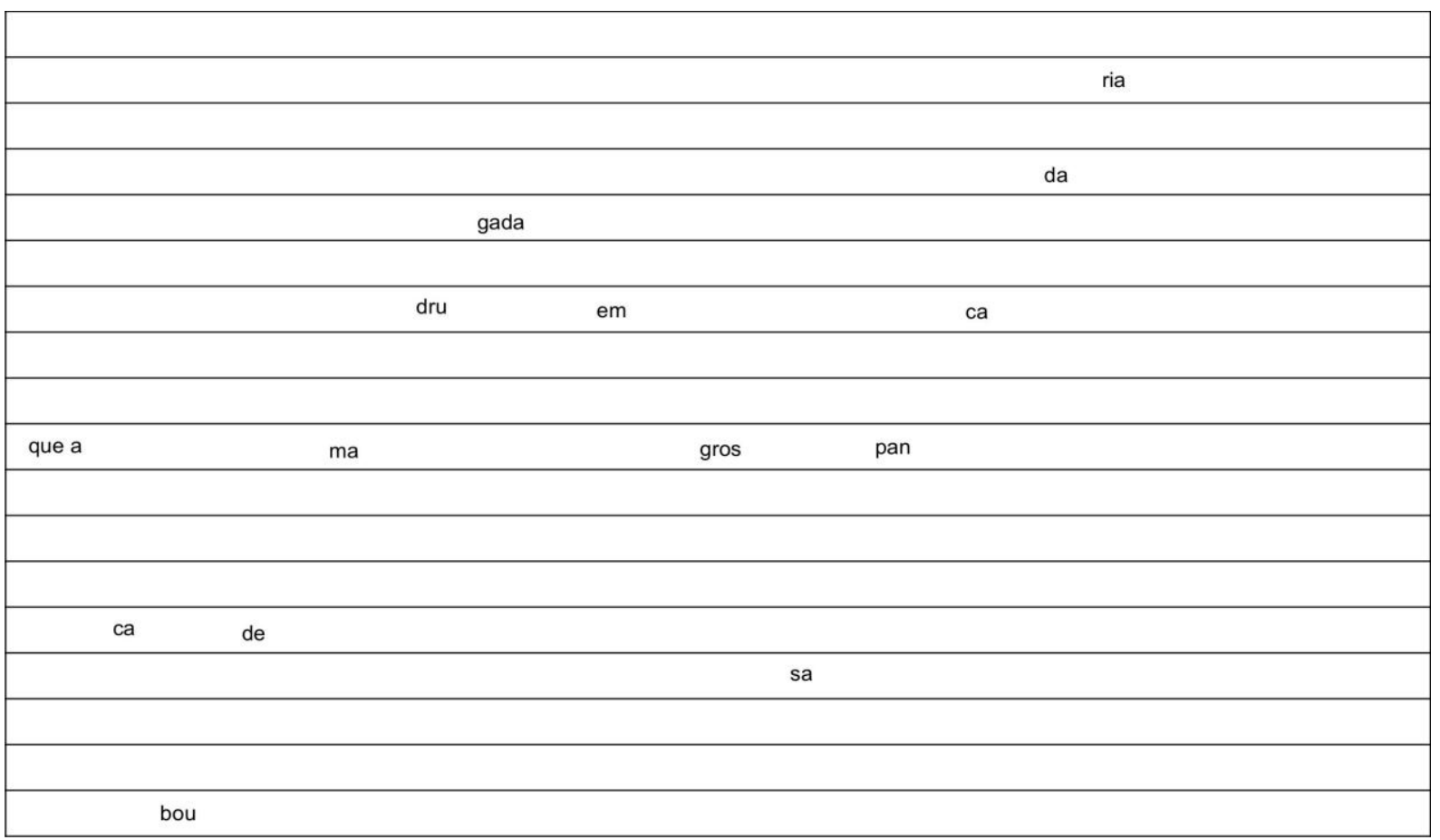

Na parte que denominamos A', chama especial atenção o verso de número 7 , cuja melodia apresenta movimentos reiterativos, configurando uma tematização interna à frase que confere intensidade dramática ao texto: "Mamei um litro e meio de cachaça,bem puxado".

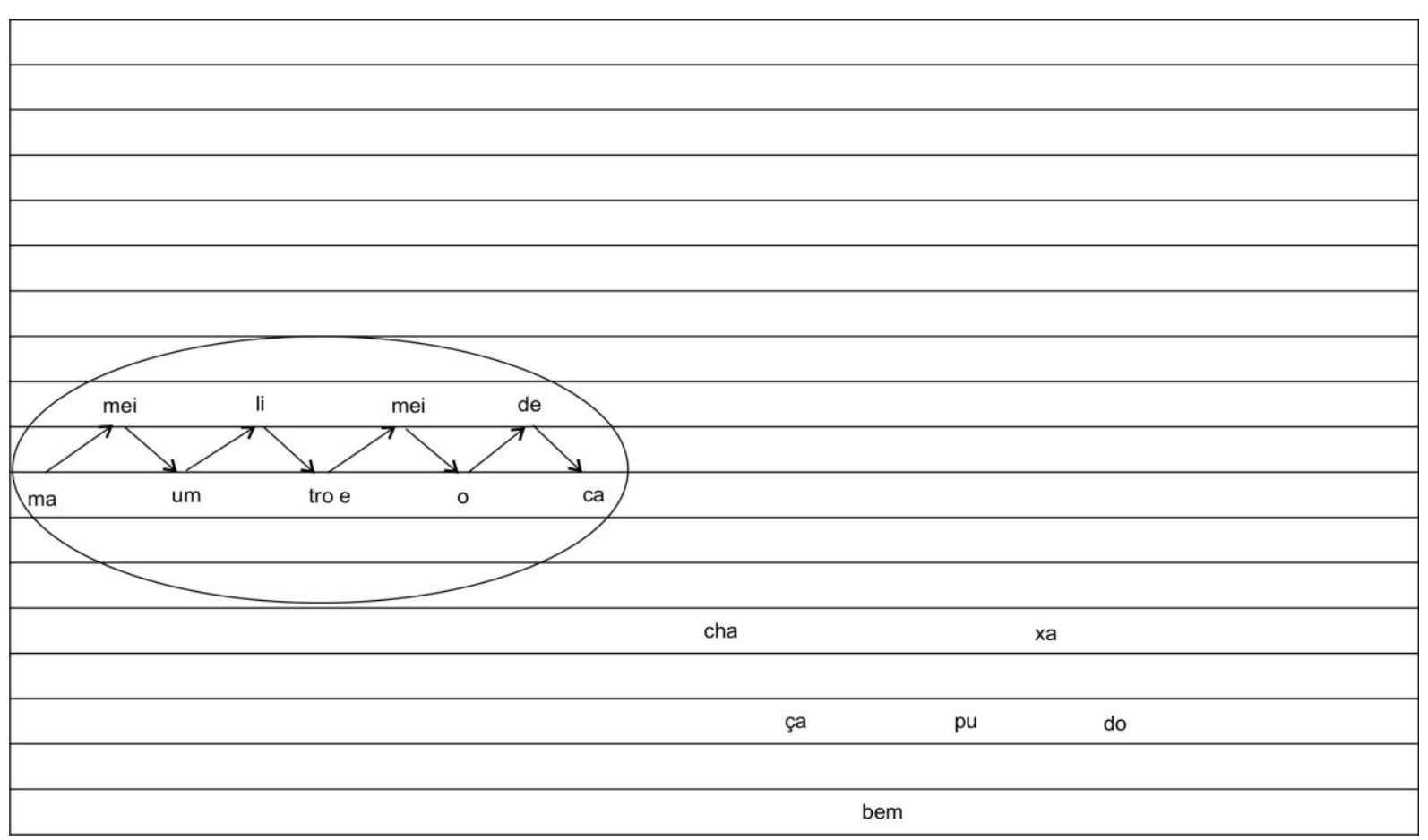


Essa reiteração melódica sobre um texto cuja imagem é tão densa (uma criança mamando um litro de cachaça) parece ejetar toda a dramaticidade contida na canção.

Com a entrada na parte $B$, instala-se momentaneamente a tonalidade menor, desenvolvendo-se a narrativa por uma série de acontecimentos trágicos, que enfatizam tudo o que já havia sido prenunciado ainda na infância da enunciadora descrita nas partes $A$ e $A$ '. A conjunção que se estabelece de forma breve, representada pelo surgimento do amor, é rapidamente desfeita pelo gesto de abandono: "Me soltou na rua à toa/ Desprezada como um cão".

A instalação do tempo presente reafirma a disjunção pelas isotopias de ausência, perda e descrença, prenunciando-se novamente um futuro que reforça a condição anunciada no início da narrativa: "Irei cada vez mais me esmolambando/ Seguirei sempre sambando/ Na batucada da vida".

\section{Análise do comportamento vocal}

\section{Carmen Miranda}

Andamento: 86 bpm

Tonalidade: $\mathrm{C}$

Tessitura: 17 semitons

Instrumentação: piano, baixo, percussão, sopros (Grupo Diabos do Céu)

Forma: A A' B B' (depois de cantado, o tema é repetido instrumentalmente)

Ano: 1934 (CD Revivendo-com fonogramas gravados pela cantora entre 1934 e 1939-Faixa 14)

Arranjo: Pixinguinha

O andamento rápido e a presença nítida da voz que fala por trás da voz que canta atenuam a percepção da tessitura descrita pela melodia. Assim, evidenciamse elementos de figurativização e uma pronunciada capacidade entoativa (falada) da cantora, que materializa as imagens descritas na letra sem, todavia, produzir efeito de sentido com os componentes da voz.

Em virtude da tonalidade escolhida (dó maior), a voz de Carmen Miranda ocupa a região médio-aguda de sua tessitura vocal, desenvolvendo-se dentro do seguinte 
intervalo: de sol2 a do4. Embora a melodia se desenvolva por uma grande extensão, o fato de a intérprete não enfatizar no canto o aspecto musical, mas sim o entoativo, traz à escuta certa naturalidade de emissão que atenua consideravelmente a percepção das distâncias melódicas.

A debreagem enunciativa ${ }^{22}$ coloca a enunciadora no centro dos acontecimentos, mas a coloquialidade da emissão, com a voz em ajuste fonatório para o registro modal, ocupando os sub-registros de peito e cabeça, não explicitam as isotopias ${ }^{23}$ de tragédia presentes na letra.

A presença de vibrato, outro dado que costuma ampliar na escuta a percepção da intensidade dramática, neste caso se dá de maneira também diferenciada, pois Carmen Miranda o utiliza nas penúltimas sílabas das palavras ("mun_do", "orgi_a", "pancadari_a", "fuma_ça", "capa_cho", "enjeita_dos") e imediatamente realiza um gesto de compensação, concluindo com um tonema descendente e breve. Assim, a maneira de emitir o som confere à voz uma leveza que não enfatiza o teor dramático da narrativa.

Esse fato nos possibilita compreender a interpretação de duas maneiras. A primeira evidencia um desejo claro da intérprete de não entrar em conjunção com a tragédia inscrita na composição, mantendo-se, assim, imune ao enunciado. Já numa segunda visão, dando voz ao sujeito da narrativa, a cantora deixa transparecer o fato de que a tragédia instalada em sua vida desde o momento do nascimento pode ter transformado todo e qualquer acontecimento, neste sentido, corriqueiro. De qualquer maneira, ambas as visões revelam o desejo de atenuar a força negativa do acontecimento narrado.

Se há uma cumplicidade entre a voz, a melodia e o componente rítmico, não se estabelece, todavia, a mesma cumplicidade entre a voz e o sentido da letra da canção. No verso número 7 , que cria uma das imagens mais pesadas do texto - "Mamei um litro e meio de cachaça, bem puxado" -, fica bastante clara a opção pela atenuação do sentido, pois a voz destaca a acentuação rítmica por meio de acentos recorrentes assinalados nas sílabas em destaque. Neste caso, ao enfatizar o componente

${ }^{22}$ Dispositivo pelo qual o enunciador projeta no enunciado marcas da enunciação; ou seja, a pessoa, o tempo e o lugar de onde se fala.

${ }^{23}$ Processo pelo qual os traços abstratos que compõem a significação das palavras convergem ao mesmo topus (lugar de sentido) e garantem ao enunciatário uma leitura homogênea. 
musical, a cantora valoriza o apelo somático desse trecho da composição e desvia a atenção da dramaticidade do texto. Ao mesmo tempo, a instrumentação corrobora esta acentuação, construindo uma rara cumplicidade, para a época, entre acompanhamento instrumental e solista.

Constatamos, então, que a cantora Carmen Miranda apropriou-se da canção, destacando na interpretação elementos que já faziam parte de seu universo musical, no qual sempre prevaleceu a capacidade entoativa e a articulação que valoriza o componente rítmico da palavra, em conformidade com a diluição da intensidade dramática.

O repertório gravado pela cantora era composto predominantemente por marchas, choros e sambas, nos quais, se havia o elemento trágico, ele não se apresentava de forma objetiva. Seu gesto vocal sempre privilegiava a leveza e a alegria, que se expressavam na articulação rítmica e na capacidade de extrair a entoação do texto verbal, destacando seu componente musical e valorizando, assim, os planos de expressão musical e linguístico.

Ao delinear seu gesto vocal sem entrar em contato com o conteúdo trágico da letra, Carmen enfatiza, pelo aspecto entoativo, a superação do seu próprio destino, conferindo outro sentido à frase: "Seguirei sempre sambando, na batucada da vida".

Nas palavras de Tatit,

Reduzindo a duração das vogais e o campo de utilização das freqüências, o cancionista produzirá uma progressão melódica mais veloz e mais segmentada pelos ataques insistentes das consoantes. Os contornos são, então, rapidamente transformados em motivos e processados em cadeia. O centro de tensividade instala-se na ordenação regular da articulação, na periodicidade dos acentos e na configuração de saliências, muito bem identificadas como temas. A aceleração dessa descontinuidade melódica, cristalizada em temas reiterativos, privilegia o ritmo e sua sintonia natural com o corpo: de um lado, as pulsações orgânicas de fundo (batimento cardíaco, inspiração/expiração) refletem de antemão a periodicidade, de outro, a gestualidade física reproduz visualmente os pontos demarcatórios sugeridos pelos acentos auditivos. Daí o tamborilar dos dedos, a marcação do tempo com o pé, ou com a cabeça e o envolvimento integral 
da dança espontânea ou projetada. A concentração de tensividade na pulsação, decorrente da reiteração dos temas, tende a um encontro com o gênero explícito: o xote, o samba, a marcha, o rock etc. É a vigência da ação. É a redução da duração e da freqüência. É a música modalizada pelo /fazer/. (TATIT, 1995, pp. 10-1)

De certa forma, a construção de seu gesto vocal termina por nos apontar uma disjunção dentro da própria composição, visto que, usualmente, canções cujas letras tratam de acontecimentos trágicos tendem a apresentar andamentos lentos. Este samba, no entanto, talvez adequado ao universo do teatro de revista para o qual foi composto, apresenta um comportamento diferenciado.

O jornalista e crítico musical Sérgio Cabral, em seu livro No tempo de Ari Barroso, no qual retrata a vida do compositor, diz que a gravação de Carmen Miranda foi um equívoco da intérprete e do arranjador, Pixinguinha.

Carmen teve muitas dificuldades para cantá-la, no estúdio da Victor, chegando a queixar-se de que Ari Barroso utilizou-se de toda a escala musical para compor o samba. Não é uma música muito fácil de ser cantada, mas não foi o excesso de notas que prejudicou a gravação, até porque o excesso de notas não é a principal característica de "Na Batucada da Vida". Ela e Pixinguinha, autor do arranjo e regente da orquestra denominada Diabos do Céu, não perceberam que a música merecia um tratamento que sublinhasse a letra de Luiz Peixoto, além de acentuar certos detalhes da linda melodia de Ari Barrroso. (CABRAL, 1993 p.130)

Sendo Carmen Miranda a cantora em questão, nos parece todavia que a opção pela maneira de construir a interpretação foi claramente escolhida pela intérprete, cuja imagem, nesse momento, era bastante definida, não cabendo uma canção de andamento lento e forte apelo dramático. Ainda que 0 arranjador pudesse estar conectado exclusivamente com a porção musical da canção, acreditamos que a interferência da cantora tenha se manifestado no sentido de valorizar o componente 
temático pela ênfase nas articulações rítmicas, atenuando a própria passionalização inscrita no percurso melódico e submetendo a letra ao poder da música, para assim enfraquecer a percepção do conteúdo pelo ouvinte.

\section{Elis Regina}

Andamento: 48bpm

Tonalidade: A

Tessitura: 17 semitons

Instrumentação: piano, baixo, bateria

Forma: Introdução A A' B B'

Arranjo: Cesar Camargo Mariano

Ano: 1974 (LP Elis - Faixa 1)

Diametralmente oposta é a interpretação de Elis Regina para a mesma canção. $\mathrm{O}$ andamento muito mais lento, a modalização da melodia e o tratamento harmônico reforçam imediatamente a percepção da passionalização que rege a integração entre melodia e letra. A escolha da tonalidade, um tom e meio abaixo da gravação original, expõe um percurso que vai de Mi2 a La3 e explora a região médio-grave da tessitura, possibilitando que a intérprete alterne procedimentos timbrísticos, ora escurecendo o timbre, ${ }^{24}$ ora enfatizando sua metalização. ${ }^{25}$

É importante destacar que Elis faz uso desses procedimentos somando-os à alteração de notas que enfatizam a percepção do percurso melódico. Em algumas frases, como na primeira, em que a melodia originalmente se desenha de maneira ascendente, ela redefine o caminho fazendo um movimento para baixo para depois ascender, ampliando o trajeto da melodia.

${ }^{24} \mathrm{O}$ escurecimento do timbre ocorre com a projeção maior de harmônicos graves da voz. Isto pode ocorrer não só pela escolha da tonalidade, mas principalmente pela maneira de emitir o som.

${ }^{25} \mathrm{Em}$ oposição ao escurecimento timbrístico, que requer uma emissão mais posteriorizada, com ocupação ampla do espaço interno da boca pelo fluxo de ar, a metalização demanda o uso de ressoadores frontais e maior pressão subglótica. 


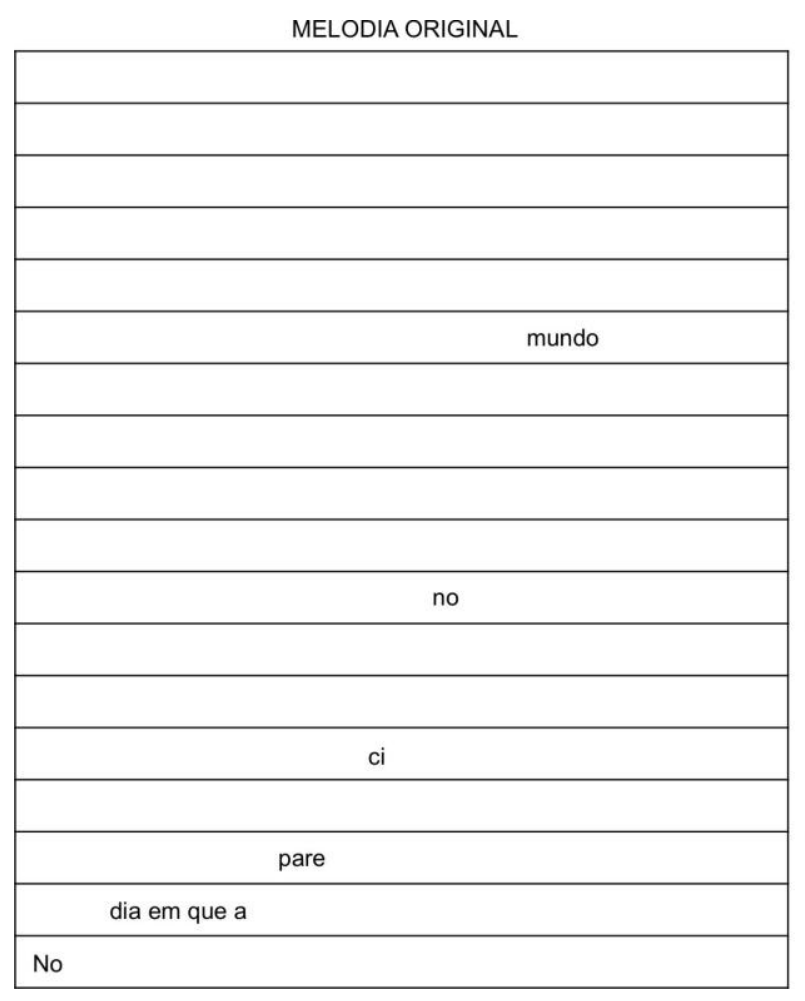

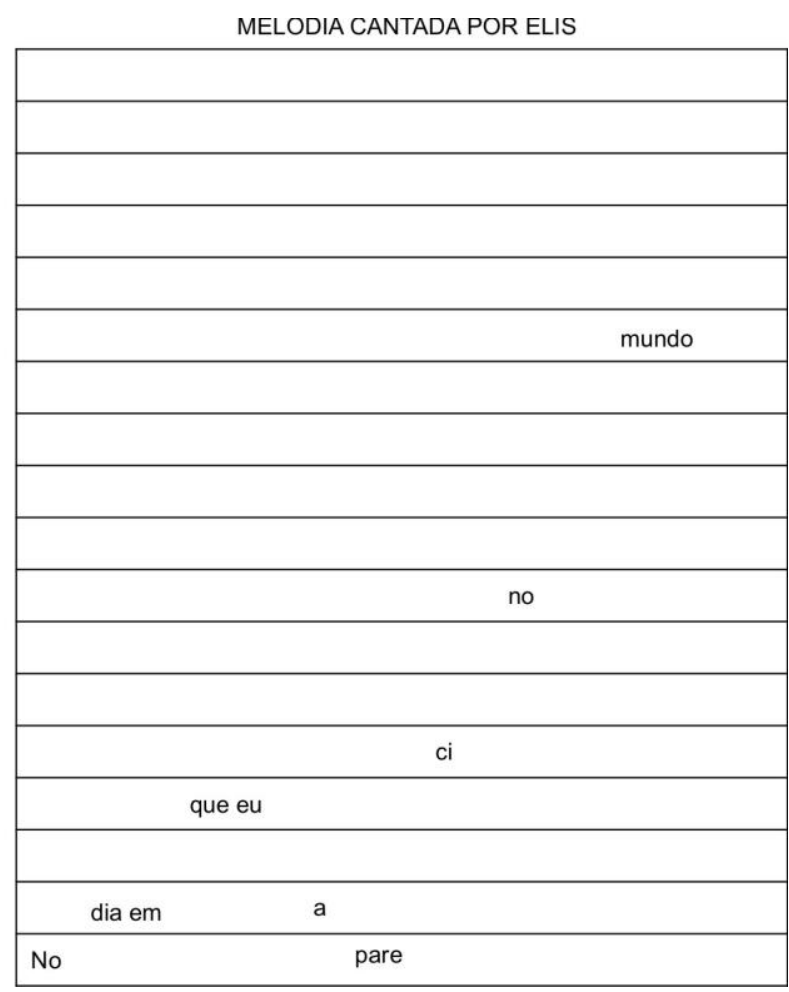

A voz da cantora apresenta-se em registro modal, com predominância exclusiva do sub-registro de peito, reiterando somente com esses elementos o caráter asseverativo da canção. Há, por toda a interpretação, um predomínio da emissão que privilegia a explicitação melódica. O uso de vibrato e a presença de notas prolongadas ao longo das frases também são fatores que acentuam o componente dramático expresso pela letra, pois enfatizam a percepção da distância presente no percurso melódico, ressaltando a passionalização e a condição de disjunção vivenciada pelo sujeito.

Nesta abordagem, a presença da tragédia desde o nascimento da personagem parece não ser aceita como fato corriqueiro, visto que a cantora faz uso de diversos recursos vocais para acentuar a percepção do drama. A articulação rítmica com prolongamento de algumas vogais, como em "Mamei um litro e meio de cachaça", e a ênfase em algumas consoantes, como em "polícia" e "malícia", somadas a uma ligeira metalização do timbre, de certa forma criam uma alteração na expressão vocal, que remete a um componente de cinismo. Esse gesto impresso no plano de expressão cria para o ouvinte a imagem de um enunciador que ironiza a própria tragédia. 
É possível perceber que o desejo de atenuação da carga dramática, que na gravação de Carmen Miranda é explorado pelo aspecto do encurtamento das durações, aqui é redimensionado pela conduta oposta. Ou seja, as sílabas marcadas são alongadas e as durações são projetadas de forma a unir as palavras, reforçando a percepção do conteúdo do texto, bem como do percurso melódico.

Já na sequência imediata desses versos, Elis executa a frase "Despertou meu coração" com uso acentuado do vibrato, prolongando as notas e tornando a emissão vocal mais fechada. Ao fazer isto, além de prestar uma reverência à sua principal influência vocal, Ângela Maria, ela transporta o ouvinte para o universo musical daquela intérprete, que foi (e é) um expoente importante: o universo das canções em que a perda é um acontecimento central necessariamente assinalado pela voz do intérprete. É importante destacar que essa conduta é utilizada no único momento em que a letra faz alusão à perda amorosa.

Elis faz uso de dinâmica crescente, do mezzo-forte para o forte, valorizando a chegada aos pontos culminantes da melodia, o que de certa forma ocorre em sintonia com a letra e reafirma o aspecto passional da interpretação.

Quando prolonga sensivelmente a duração das vogais e amplia a extensão da tessitura e dos saltos intervalares, cai imediatamente o andamento da música, desvelando com nitidez e destaque cada contorno melódico. É a tensão que se expande em continuidade, explorando as freqüências agudas (aumento de vibrações das cordas vocais) e a capacidade de sustentação de notas (fôlego e energia da emissão). É a tensão do perfil melódico em si que alinhava as vogais. (...) É quando o cancionista não quer a ação mas a paixão. Quer trazer o ouvinte para o estado em que se encontra. Nesse sentido, ampliar a duração e a freqüência significa imprimir na progressão melódica a modalidade do /ser/. (TATIT, 1995, p.10)

Em sua versão de "Na Batucada da Vida", Elis Regina, livre de qualquer preocupação com uma imagem pré-estabelecida, pôde expressar sua imediata 
identificação com a letra, alterando sem maiores pudores alguns elementos da melodia que contribuíam diretamente para o distanciamento da significação construída pelo texto. Não estando presa a uma única imagem pública, como se dava com a cantora Carmen Miranda, e sobretudo livre do julgamento dos próprios compositores quanto às mudanças produzidas na melodia, Elis pôde reconstruí-la de acordo com sua própria compreensão e intenção dramática. Vale observar que também neste caso a presença do arranjador, Cesar Camargo Mariano, certamente contribuiu, com sua re-harmonização, para respaldar ou mesmo redirecionar o olhar da cantora sobre a composição.

\section{Ná Ozzetti}

Andamento: $71 \mathrm{bpm}$

Tonalidade: $\mathrm{C}$

Tessitura: 17 semitons

Instrumentação: violão, cello, contrabaixo, percuteria

Forma: Introdução A A' B B' Intermezzo A A' e B instrumental B voz Coda

Ano: 2009 (CD Balangandãs - Faixa 8)

Arranjo: Dante Ozzetti

A cantora Ná Ozzetti, ao longo de sua carreira, tem primado por realizar releituras de clássicos da canção popular de maneira muito própria, muitas vezes transportando essas canções para universos musicais bastante distanciados daqueles de origem da canção, como se pode observar nas regravações de "Sua Estupidez" e "No Rancho Fundo". No caso desta regravação, no entanto, Ná se manteve próxima da referência original, ou seja, da gravação de Carmen Miranda, escolhendo para cantar a mesma tonalidade utilizada pela intérprete. Sua gravação está inserida no $C D$ Balangandãs, dedicado a reler parte do repertório de Carmen Miranda, fato que sugere sua intenção em manter elos com as gravações originais desta artista.

Ao adotar determinados comportamentos vocais, Ná Ozzetti conseguiu, todavia, evidenciar o conteúdo dramático da letra, reconstruindo o elo com a melodia sem alterála, mudando apenas ligeiramente o andamento original. É possível afirmar que sua versão equilibrou elementos da composição que, ao que tudo indica, haviam sido 
redimensionados nas versões anteriores. Assim, é possível compreender, como destacamos anteriormente, o quanto a interferência do intérprete, por seu gosto, estilo e até imagem pública, pode evidenciar os elementos inscritos em uma canção ou mesmo alterar esses elementos mediante a construção de um gesto vocal. O que a versão de Ná Ozzetti torna visível é que ela pôde construir o seu gesto sem promover nenhuma alteração significativa na melodia ou na letra, fazendo uso exclusivo de algumas mudanças de sub-registro vocal e enfatizando determinados tonemas, como veremos a seguir.

Embora haja alguns pontos diferenciados na melodia entre sua gravação e a de Carmen Miranda, não são alterações substanciais feitas intencionalmente para ressignificar a canção do ponto de vista do intérprete, como ocorreu na gravação de Elis Regina. As poucas alterações parecem resultado da ação do tempo sobre a canção, quando, por ter sido regravada tantas vezes, já não se sabe mais ao certo como é a melodia original.

No início da canção, Ná realiza uma terminação na palavra "mundo". Aplica a ela um tonema descendente, glissando a nota final; distancia-se da altura definida da melodia e se aproxima de um padrão entoativo (falado), largando a emissão como se desejasse expressar desleixo. A seguir, complementa essa intenção finalizando a frase "Juntou uma porção de vagabundos da orgia", sujando acentuadamente a emissão na palavra final. É possível depreender dessa atitude vocal o desejo de exprimir no campo sonoro a significação do texto poético. Assim, já no início da canção, a maneira de abordar as notas, nesta frase que situa o ambiente do nascimento do sujeito da enunciação, faz uma síntese de todo o contexto que se apresentará ao longo de toda a execução.

Abrimos aqui uma brecha para explicar o conceito de "sujeira" na voz. Utiliza-se de modo amplo as terminologias "suja" e "limpa" para identificar aspectos referentes a um índice maior ou menor de ruído na produção vocal. Uma voz "suja" é aquela na qual se ouve, além das alturas expressas pela linha melódica, um pequeno chiado, uma projeção de ar ou mesmo um ligeiro tensionamento que resulta numa quase rouquidão. Por oposição, uma voz "limpa" é aquela na qual se ouve apenas a pureza das alturas da melodia expressas pelo timbre. 
Isto posto, retomemos a análise. Mais à frente, na frase "Mamei um litro e meio de cachaça, bem puxado", a cantora distende o tempo interno das palavras "cachaça" e "puxado", alongando a segunda sílaba de cada uma, produzindo no ouvinte a sensação de intensidade do ato. Vemos aqui uma ação local que valoriza o plano da expressão, ao mesmo tempo em que explicita o plano do conteúdo.

Nas frases seguintes, a expressão da fragilidade do enunciador se dá pela alteração do sub-registro vocal. A passagem da ressonância baixa para a alta, com um ligeiro tremor na voz, é o elemento que traduz no campo sonoro a condição passiva do enunciador ante o abandono. Essa atitude vocal permanece até o final da exposição do tema, quando o sujeito resignado reconhece sua condição ao afirmar, de maneira metafórica, que seguirá "sempre sambando na batucada da vida".

\section{Conclusão}

Se na gravação de Carmen Miranda há uma dose de impessoalidade na voz do enunciador que comparece no enunciado - e o que captura o ouvinte é a capacidade de explicitação entoativa da cantora -, na gravação de Elis Regina a voz é cúmplice da narrativa. Essa cumplicidade já se revela desde a concepção do arranjo até as alterações da melodia; pronuncia-se categoricamente quando, ao mudar a palavra "sambando", presente na última estrofe, para "cantando", a intérprete se coloca de modo evidente no centro da narrativa, assumindo, efetivamente, o papel de sujeito da enunciação.

Já na versão de Ná Ozzetti, a cumplicidade se estabelece com a canção, ou seja, com o elo existente entre melodia e letra, e ela constrói todo o seu gesto vocal a serviço da explicitação desse elo. Ao fazer isso, a melodia, que aparentemente estava desconectada da letra, revela a sua cumplicidade. Desta forma, fica claro que a cantora construiu sua interpretação não submetendo exclusivamente a composição à sua personalidade artística ou a uma leitura personalista.

É possível depreender, desta forma, que cada intérprete estabeleceu elos diferentes com a canção para criar sua interpretação. No caso de Carmen Miranda, o 
elo direto deu-se com a melodia, resultando numa interpretação na qual não ocorreu a valorização do componente dramático da letra e que se mostrou, assim, predominantemente tematizada. Já na versão de Elis Regina, sua identificação imediata com a letra provocou alterações na composição original para ajustá-la ao universo dramático do texto, evidenciando o caráter passional da interpretação. Por fim, a cantora Ná Ozzetti permitiu, primeiro, que a canção falasse através de sua voz, para depois criar marcas de sua leitura, expondo os elos dramáticos contidos na composição. Conseguiu manter viva em sua interpretação a proposta inaugural de Carmen Miranda e, ao mesmo tempo, construir uma leitura particular da canção, deixando clara sua interferência e seu gesto interpretativo.

É comum no universo da canção popular que as letras, e mesmo as melodias, sofram pequenas alterações ao longo dos anos e das diversas gravações, já que, na maioria dos casos, a canção popular se aprende por meio da escuta, e não da linguagem escrita, como na chamada música erudita. Desta forma, ela termina (ou começa sua jornada) propagando-se como numa brincadeira de telefone-sem-fio, produzindo resultados com algumas diferenças daquilo que seria a referência original. No caso desta canção, especificamente, fica claro que, além de sofrer esse processo natural, houve intenção por parte das intérpretes na realização de algumas modificações que, por um lado, corroborassem o sentido profundo da canção e, por outro, imprimissem características de seus gestos interpretativos.

Ao analisar o gesto vocal do cantor, é possível observar como as composições têm maleabilidade e vida própria. Na maioria das vezes, para muito além daquilo que o próprio compositor projetou ou vislumbrou em sua obra, o intérprete é capaz de se apropriar da canção, elucidando, a cada nova leitura, sentidos que pareciam ocultos. No caso das três gravações analisadas, observa-se que o gesto vocal de cada intérprete - projetando-se na obra e extraindo dela elementos diversos, recriando e sobretudo particularizando o fazer musical - torna a presença do cantor, feito cancionista, indispensável à genealogia da canção. 


\section{8 "SAMBA DO AVIÃO" (Tom Jobim)}

No final dos anos 1940, através do rádio e do cinema, a música popular norteamericana imprimia com força absoluta sua influência sobre os jovens artistas brasileiros. Nesse ambiente, sob a égide do cool jazz e da música clássica, o compositor Antônio Carlos Jobim inicia sua carreira, cujo ápice seria atingido após o final da década de 1950.

O "Samba do Avião" teve sua primeira gravação em 1963, pelo grupo vocal Os Cariocas. No entanto, escolhemos para análise a gravação realizada pelo próprio Tom Jobim em 1965, presente no LP The wonderful world of Antonio Carlos Jobim, segundo trabalho solo do artista, gravado nos Estados Unidos.

O motivo da escolha foi analisar o componente vocal do compositor, que, como aponta Tatit (1995, p. 160), "pôs toda a sua competência musical (teórica e intuitiva) a serviço da canção". Essa competência, como veremos na análise, também criou marcas específicas no gesto vocal, fixando uma vocalidade passível de reconhecimento.

O canto de Tom Jobim parecia carregar, simultaneamente, a mesma leveza (melódica) e densidade (harmônica) de suas canções, tornando-se um gesto particular carregado de sentido e diverso daqueles construídos pelos cantores que, à época, se dedicaram a ler sua obra - exceção feita a João Gilberto, como veremos também à frente.

Já a releitura realizada por Gilberto Gil em 1977 constrói, sob forte influência do movimento "Black Rio"26, outros elos com a canção que não mais aqueles orientados por uma estética da Bossa Nova. Gil imprime um novo tônus ao acelerar o andamento e

\footnotetext{
${ }^{26}$ Sobre o movimento Black Rio, ver o artigo: A sonoridade da banda Black Rio, de José Roberto Zan. Disponível em http://www.nics.unicamp.br/muspop/Musica_Popular/Publicacoes_files/robertozan.pdf.
} 
adicionar elementos do rock e do funk, valorizando os estímulos somáticos delineados pelo ritmo e exaltando, com sua interpretação, os aspectos eufóricos inscritos na canção.

\section{Samba do Avião (Tom Jobim)}

1 Minha alma canta

2 Vejo o Rio de Janeiro

3 Estou morrendo de saudades

4 Rio, seu mar

5 Praias sem fim

6 Rio, você foi feito pra mim

7 Cristo Redentor

8 Braços abertos sobre a Guanabara

9 Este samba é só porque

10 Rio, eu gosto de você

11 A morena vai sambar

12 Seu corpo todo balançar

13 Rio de sol, de céu, de mar

14 Dentro de mais um minuto estaremos no Galeão

15 Cristo Redentor

16 Braços abertos sobre a Guanabara

17 Este samba é só porque

18 Rio, eu gosto de você

19 A morena vai sambar

20 Seu corpo todo balançar

21 Aperte o cinto, vamos chegar

22 Água brilhando, olha a pista chegando

23 E vamos nós

24 Aterrar... 


\section{Sobre a canção}

A canção é constituída por três partes - A, A' e A"-, que se comportam de maneira muito semelhante do ponto de vista melódico-harmônico, apresentando, no entanto, terminações diferentes. O desenvolvimento inicial pelo eixo da tessitura é imediatamente estabilizado por motivos nos quais a melodia se apresenta bastante concentrada. Além disso, o apelo rítmico instaura os processos reiterativos que estabelecem a conjunção com a letra.

O regime de integração entre melodia e letra é a passionalização. As gradações ascendentes estabelecem uma lei clara para a chegada nos pontos mais agudos da melodia, instalando uma desaceleração e uma certa previsibilidade no percurso, que é reiterada pela presença de um motivo tematizado, que finaliza a primeira parte: "Rio seu mar/ praias sem fim/ Rio você foi feito pra mim".

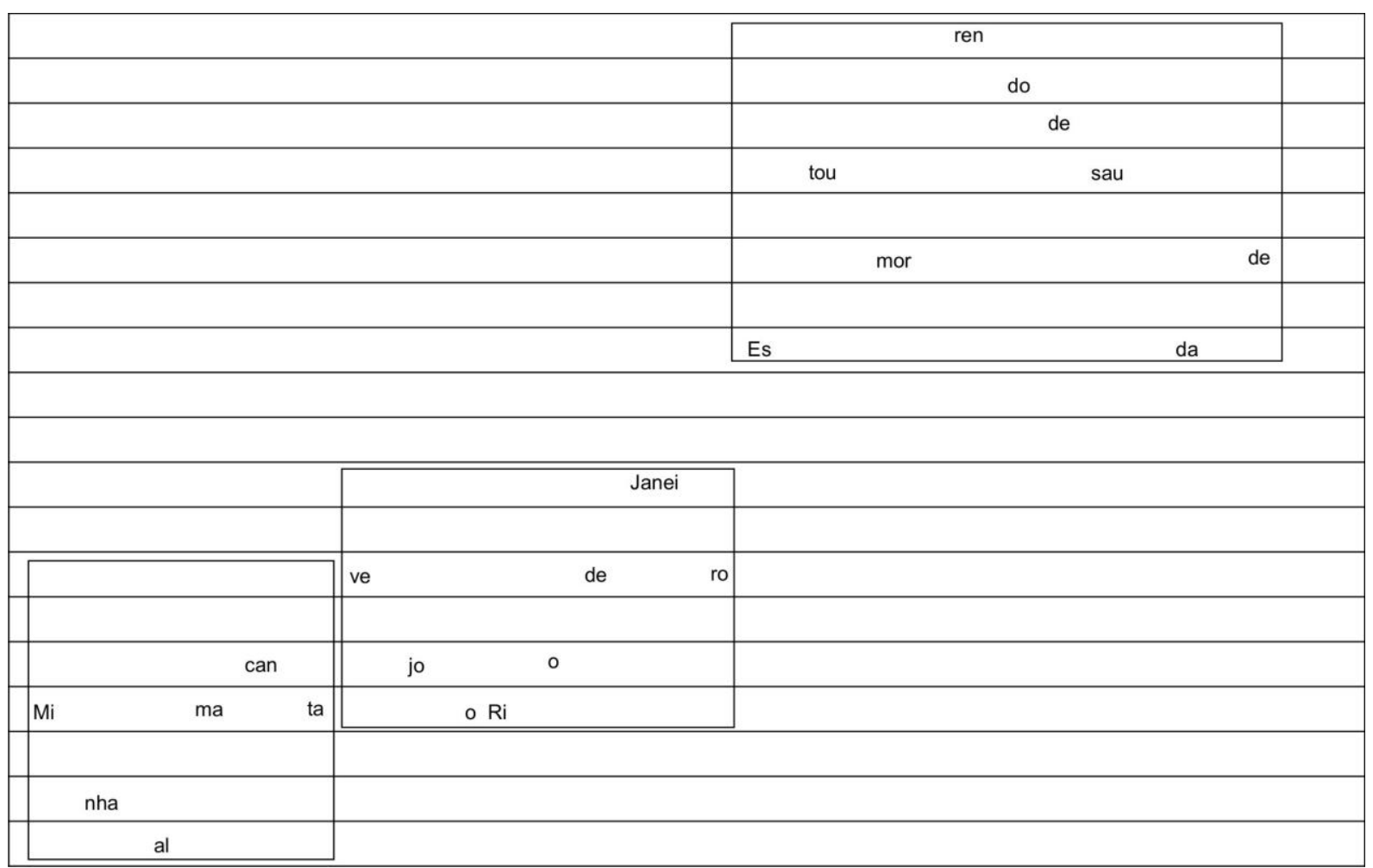




\begin{tabular}{|l|}
\hline \\
\hline Rio teu mar Praias sem fim Rio vocé foi feito pra mim \\
\hline \\
\hline
\end{tabular}

Na parte A', o projeto de expansão lenta se mantém, visto que os dois versos iniciais (7 e 8) apresentam uma melodia que se expande pelo campo da tessitura em direção ascendente; e, na sequência, instalam-se novamente motivos rítmico-melódicos nos quais ocorre uma concentração maior, em termos de tessitura, havendo também, entre eles, uma gradação descendente.

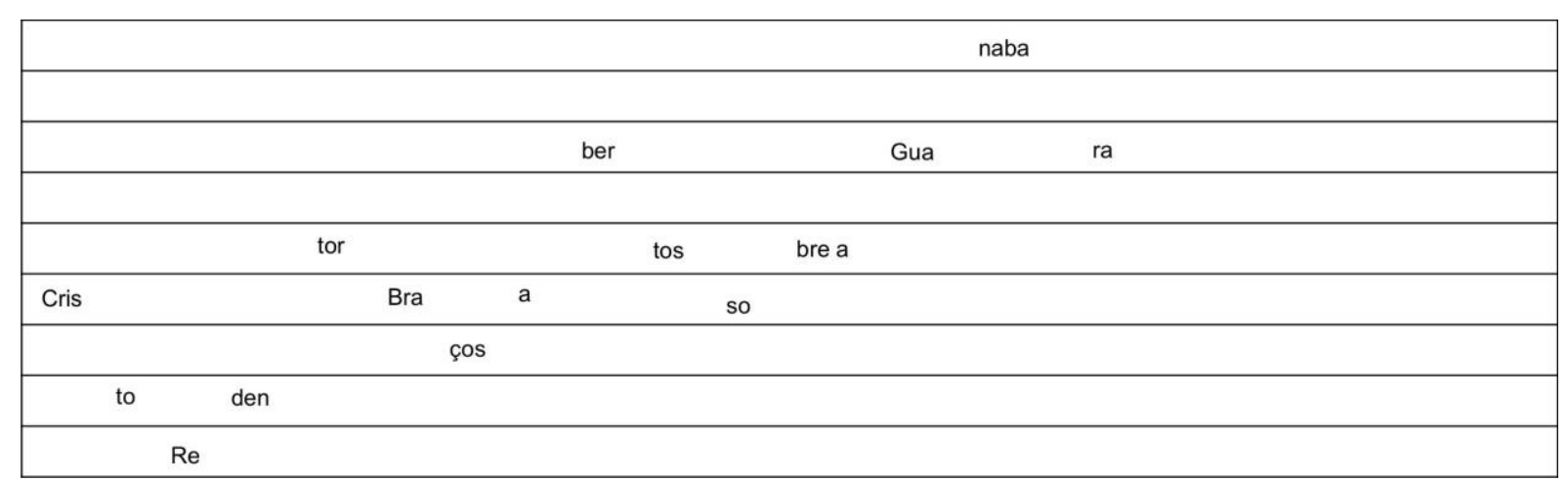

Sobre o verso 9 - "Este samba é só porque" - desenha-se uma melodia descendente, como dissemos, cujo motivo se repete de maneira idêntica sobre o verso 10 "Rio eu gosto de você" -, mas com uma transposição de registro (uma 4⿳亠丷a abaixo) que novamente aponta a ideia de percurso atenuada por uma imediata concentração melódica. 


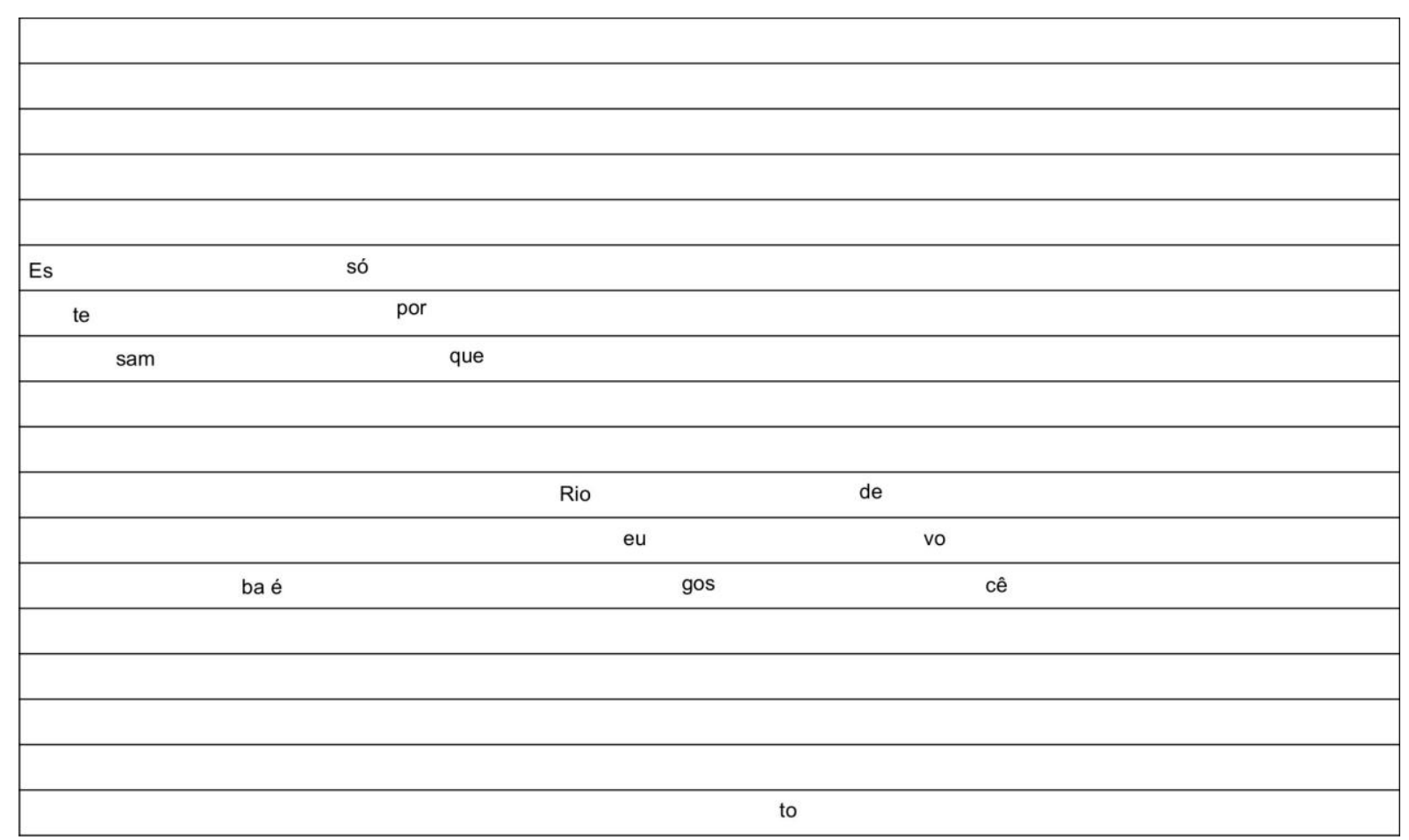

Essa ideia de expansão seguida de alguma concentração mantém-se sobre toda a seqüência iniciada no verso 11 - "A morena vai sambar" -, cuja a melodia e o ritmo se desenham iguais ao verso 9 , e prossegue nos versos 12 e 13.

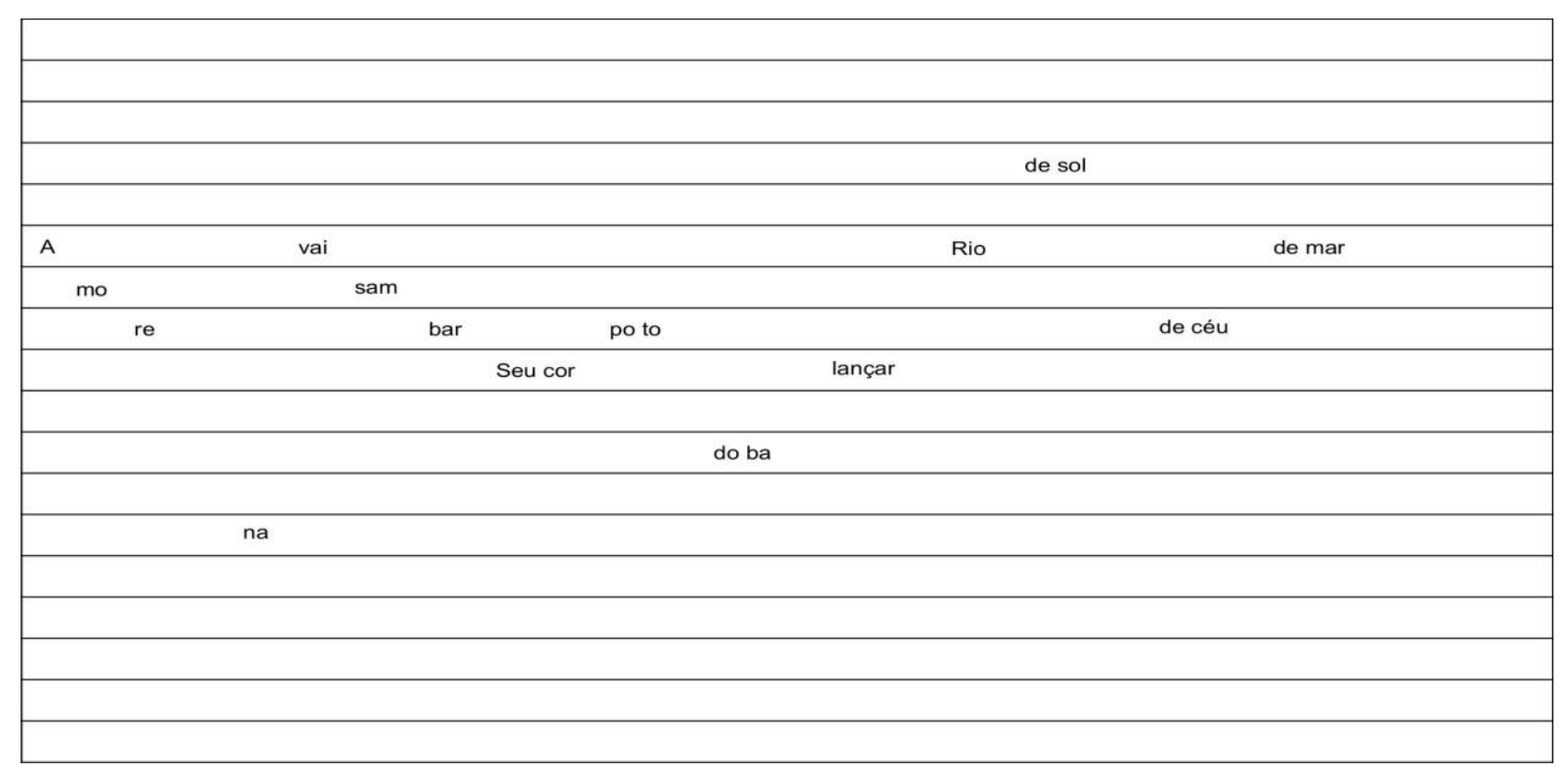

A conclusão dessa parte se dá com o verso 14, que volta a destacar a ideia de expansão pelo campo da tessitura. A frase que finaliza, sem produzir efeito de resolução harmônica, completa esse sentido de disjunção temporária entre sujeito e objeto. 


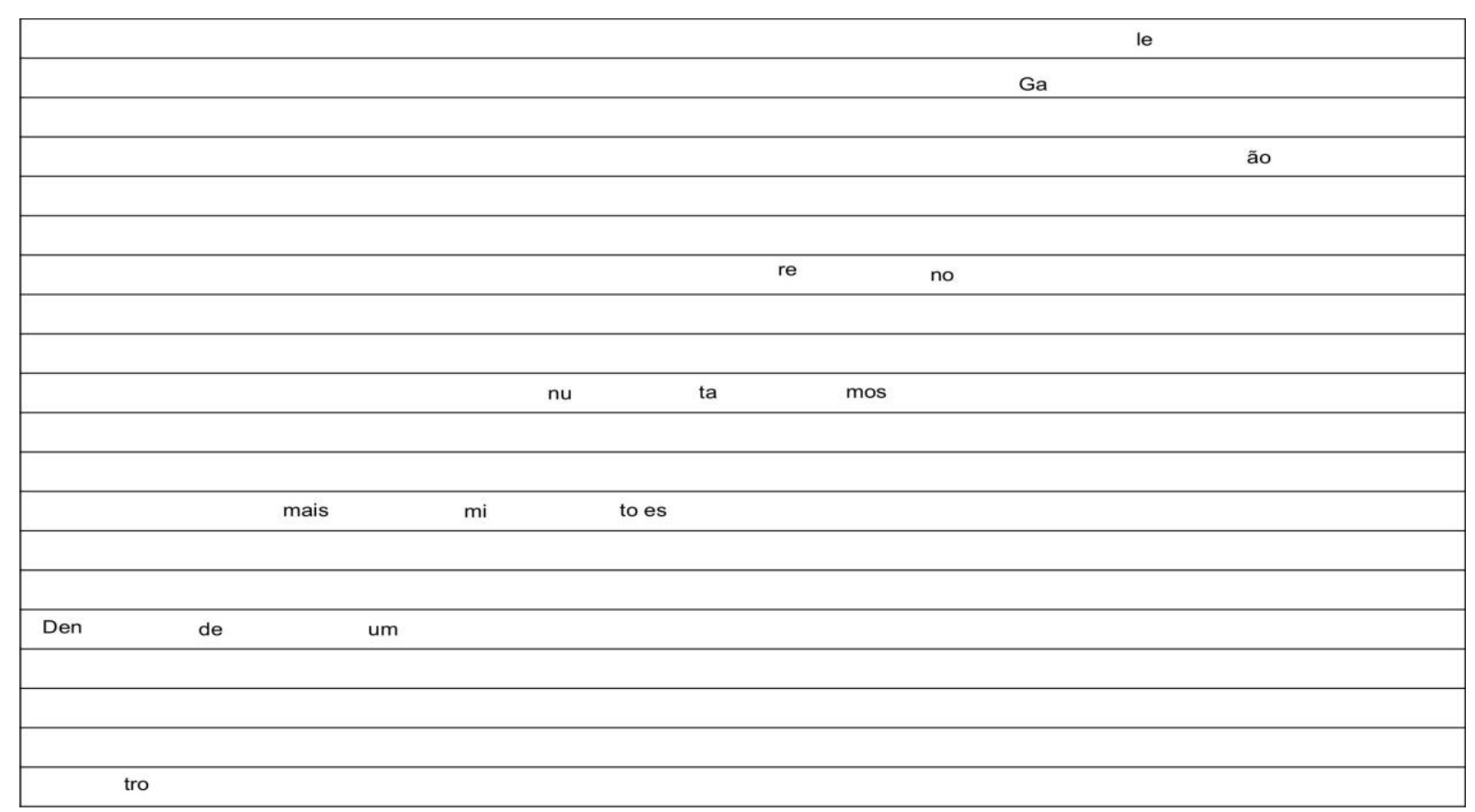

A parte A" apresenta, estruturalmente, dois versos a mais que a parte A'. No entanto, em sua gravação, Tom Jobim suprime os dois versos iniciais e prossegue até o final, no qual o texto revela o momento da conjunção sendo realizada: "Aperte o cinto, vamos chegar/ Água brilhando, olha a pista chegando/ E vamos nós/ Aterrar". A inclusão do verbo que estabelece a conjunção total se dá em concomitância com a resolução melódico-harmônica, visto que a nota cantada corresponde ao primeiro grau da tonalidade.

Como referem Lopes e Tatit,

O gênero de letra mais compatível com esse tratamento melódico é o que se enquadra num domínio intermediário de não-disjunção, ou seja, de distanciamento espacial entre actantes combinado com intenso vínculo temporal. A esperança de atingir a conjunção plena já vem expressa na evolução planejada do percurso melódico: só depende do tempo, e o tempo está sob controle. (2008, p. 23)

De fato, a letra fala da saudade, da alegria de rever a cidade amada e da conjunção que vai se estabelecendo, primeiro pelo sentido da visão e, depois, por uma metáfora para o sentido tátil, expressa pelo fato de o avião tocar o solo. Com essa 
imagem, completa-se o percurso de busca do sujeito, que entra, desta forma, em conjunção com o objeto.

\section{Análise do comportamento vocal}

\section{Tom Jobim}

Andamento: 82bpm

Tonalidade: A

Tessitura: 21 semitons

Instrumentação: violão / contrabaixo/ bateria / orquestra

Forma: Introdução A B A (instrumental) B' Coda final Instrumental

Ano: 1965 (The wonderful world of Antonio Carlos Jobim - Faixa 10)

Arranjo: Nelson Ridle

A voz de Tom Jobim apresenta-se na região médio-grave de sua tessitura. Ele alterna pelo menos dois tipos de emissão: uma extremamente airada, concentrada na região grave da voz, que produz um corpo timbrístico mais denso e escuro "Minha alma canta/ Vejo o Rio de Janeiro" -, e outra extremamente leve, com timbre mais claro, que traduz um componente coloquial, pela proximidade com a fala - "Este samba é só porque/ Rio eu gosto de você/ A morena vai sambar/ Seu corpo todo balançar".

Na parte $A$ da canção, o intérprete adota uma emissão que projeta as durações alongadas, sendo possível antever um enunciador modalizado pelo /ser/. Mesmo do $4^{\circ}$ ao 6 verso, quando o componente rítmico tematizado se manifesta de modo mais acentuado na melodia, ele opta pelo prolongamento das notas, interligando as frases: "Rio, seu mar/ Praias sem fim/ Rio você foi feito pra mim". Ao realizar esse movimento, Tom enfatiza a presença das durações alongadas e projeta, sobre a composição, uma interpretação passionalizada, que torna claro o desejo de conjunção, ainda que a disjunção temporária esteja instalada entre sujeito e objeto. 
Por toda a canção, é possível compreender que Tom Jobim configura aspectos de seu canto ora mais, ora menos passionalizado, pelas escolhas timbrísticas e pela articulação rítmica. No primeiro trecho citado, ele faz referência a um estado eufórico instalado pela conjunção visual estabelecida com a cidade amada. Porém, a escolha do timbre mais escuro mostra-se como o recurso utilizado para exprimir um estado disfórico diante da condição de estar ainda apartado do objeto, com o qual se estabeleceu, até então, uma conjunção parcial.

Tom explora a duração das notas sem a utilização de vibrato, e, desta maneira, o aspecto passional se mostra atenuado, dando-se, no entanto, pelo escurecimento do timbre e pela presença de ar na voz, somados a uma valorização das vogais, que termina por criar uma única articulação para a realização dos versos de 4 a 6 . Assim, ainda que esses versos se desenvolvam sob predomínio da tematização, visto que há repetição de notas e de motivos rítmicos, o gesto vocal interligando as frases produz efeito de elo e passionaliza a interpretação.

Já na parte A', a voz apresenta-se regida por um estado mais ativo, modalizado pelo /fazer/, e a ênfase projeta-se sobre a articulação rítmica, valorizando os impulsos somáticos inscritos na melodia. É possível, pela escuta, detectar a presença do sorriso que contribui para tornar a emissão mais leve, compatível com as imagens de beleza e sensualidade expressas na letra. Mesmo nesse momento, porém, Tom não abre mão completamente das emissões que valorizam as durações, as quais se apresentam sempre livres de vibrato e apontam uma grande coloquialidade, atenuando, portanto, mais uma vez, o aspecto passional inscrito na composição.

Nesta gravação, há um intermezzo instrumental no qual ocorre uma modulação de meio tom para cima, que é mantida na retomada da voz na parte que denominamos A". Assim, o movimento de expansão da tessitura é corroborado também pelo arranjo, que realiza uma dinâmica crescente somada à modulação ascendente, produzindo efeito de euforia no plano de expressão. 
Ainda que a estrutura inicial de A" seja semelhante a de A', o intérprete suprime os dois versos iniciais, eliminando desta maneira as frases nas quais estariam presentes mais claramente os movimentos de expansão melódica: "Cristo Redentor/ braços abertos sobre a Guanabara". Ao adotar essa conduta, ele revela, nesta parte da interpretação, a escolha pela exposição do estado eufórico expresso pelo componente rítmico presente nos versos de 17 a 22. Essa pequena mudança na forma musical instala mais prontamente a celebração que decorre da conjunção total expressa no verbo "aterrar" e na nota entoada, que também exprime finalização.

\section{Gilberto Gil}

Andamento: 92bpm

Tonalidade: $\mathrm{G}$

Tessitura: 21 semitons

Instrumentação: baixo/ naipe de metais/violão/guitarra/teclado/ bateria/percussão

Forma: Introdução A B' Intermezzo (mesmo tema da Intro) A B'

Ano: 1977 (LP Refavela - Faixa 7)

Arranjo: Gilberto Gil e Perinho Santana

Embora o arranjo não esteja entre as prioridades do nosso trabalho, no caso desta gravação chamamos a atenção para o fato de que o componente temático que se fará presente na voz já comparece na introdução. Essa estrutura de oito compassos se repete duas vezes, apresentando, de início, um motivo rítmico-melódico, que é tocado pelo contrabaixo e complementado por teclado e guitarra, enquanto a voz, instrumentalmente, insere alguns comentários, fazendo uso do falsete. A partir do $5^{\circ}$ compasso, a voz, já no registro modal, passa a enunciar o motivo central, sendo complementada pela flauta e pelos metais.

Essa integração entre voz e instrumentos permite antever o caráter de celebração que se instalará como componente profundo do canto de Gilberto Gil. A escolha do 
andamento mais acelerado revela que o intérprete priorizará os impulsos somáticos, enfatizando o caráter solar da composição.

De início, a voz exibe o campo médio-agudo de sua tessitura e faz uso de uma emissão vocal frontalizada, que resulta em um timbre claro e numa articulação rítmica que evidencia o contraste entre notas prolongadas e terminações destacadas e breves: "Mi-----nha alma can-------ta/ Vejo o Rio de Janei----ro". Os tonemas descendentes inserem o componente de fala e materializam a presença do enunciador. Já o staccato ${ }^{27}$ realizado nas sílabas em negrito reforça a ênfase no aspecto rítmico, que privilegia a ação local e não o percurso. Intencionalmente, Gilberto Gil acentua as sílabas fracas das palavras, sobrepondo ao fonema a articulação musical. Esses gestos apontam para uma realização vocal modalizada pelo /fazer/ e coloca o cantor/enunciador como agente da transformação que ocorrerá brevemente no estado juntivo.

Façamos, agora, uma observação quanto à forma adotada, que de certa maneira reflete o índice tensivo de cada interpretação. Na gravação de Tom Jobim, a forma A A' A (inst.) A" faz o percurso ser ampliado, provocando um adiamento na conjunção anunciada. Esse fato é percebido se observarmos o final da parte $A^{\prime}$ "Dentro de mais um minuto estaremos no Galeão" -, que conduz a um intermezzo instrumental para só depois retornar ao A", parte na qual se encontra o desfecho da narrativa: "Água brilhando, olha a pista chegando/ E vamos nós.../ Aterrar".

Na gravação de Gilberto Gil, no entanto, o intérprete suprime a parte A', indo diretamente ao A", em que o procedimento da aterrissagem é enunciado. Também com esse gesto ele enfatiza o desejo de estabelecer de maneira breve a conjunção, valorizando as ações intensas como delineadoras de sua interpretação.

Após o solo, o tema é repetido integralmente, porém, quando chega ao final de A", no $23^{\circ}$ verso, Gil acessa o registro elevado, emitindo em falsete o trecho "E vamos nós"; e também fará uso do falsete para finalizar a composição: "Aterrar".

\footnotetext{
${ }^{27}$ Redução da duração do som a mais ou menos metade do valor habitual.
} 
De certa forma, é possível considerar que é usada intencionalmente, pelo intérprete, a ideia da oposição entre a emissão vocal, que faz uso do registro elevado, projetando-se na direção extremo-aguda, e o gesto da aterrissagem, que estabelece a conjunção entre sujeito e objeto pelo contato com o chão. Ainda a utilização do falsete nesse trecho insere, na interpretação, o grito que remete ao contexto tropicalista, trazendo para a melodia bossanovista uma gestualidade do rock. Esta fusão consolida a identidade do intérprete, bem como enaltece o componente eufórico e festivo como condutor do gesto interpretativo delineado por Gilberto Gil.

\section{Conclusão}

Estas duas gravações ilustram, de maneira clara, o quanto a interpretação pode evidenciar ou mesmo atenuar o projeto de integração entre melodia e letra presentes na composição.

A realização de Tom Jobim compatibiliza-se predominantemente com a passionalização, embora deixe transparecer, de acordo com a presença de elementos mais tematizados na própria composição, alguma leveza característica de um estado mais eufórico.

Ele valoriza as durações presentes na parte $A$, que se compatibilizam com o estado disfórico do sujeito movido pela saudade: "Estou_morrendo de sauda__de_". No entanto, como já vimos, a ausência total de vibrato atenua consideravelmente o aspecto dramático da interpretação. Nas partes em que a melodia se tematiza - "Rio seu mar, praias sem fim / Rio você foi feito pra mim" - e que ocorre uma ligeira sobreposição de um estado de euforia, o intérprete mantém uma expressão com algum componente disfórico, que se manifesta pelos prolongamentos nas finalizações e que cria elos entre as frases. Mas, por uma operação no timbre (mais claro) e na emissão (mais leve), ele traduz a euforia que nesse momento se projeta mais claramente na composição. 
Já na versão de Gilberto Gil, a tematização vocal e um estado acentuado de euforia são absolutamente predominantes. A articulação rítmica que privilegia os recortes nas durações, somadas ao andamento, atenuam a percepção do percurso melódico. O caráter de celebração pela conjunção que se dará em um tempo curto é o que orienta a interpretação e particulariza o gesto do intérprete, quase anulando a passionalização inscrita originalmente na composição. 


\section{5 \\ GESTO VOCAL E SIGNIFICAÇÃO: UM INVENTÁRIO DAS VOZES ANALISADAS}




\subsection{ALGUMAS CONSIDERAÇÕES}

Neste trabalho, propusemo-nos a observar os diversos recursos adotados pelos intérpretes, ao longo da história da canção brasileira midiatizada, para construir significados através de suas vozes, traduzindo desta maneira os conteúdos inscritos nas composições.

Acrescentando à Teoria Semiótica da Canção elementos particulares da análise do comportamento vocal, pretendemos viabilizar uma compreensão mais profunda do canto popular no Brasil, destacando que essa história foi sendo construída ao longo do século XX basicamente pelo talento e desejo de nossos cantores de inscreverem suas marcas interpretativas em nossa cultura midiatizada e, talvez mais ainda, em nossa memória afetiva.

Neste capítulo, partindo das análises realizadas, procuramos organizar um inventário dos gestos vocais examinados para detectar de que maneira as articulações do canto poderiam ser analisadas sob o aspecto tensivo, articulando-se nos planos local e global.

Chegamos, por meio das análises, à compreensão de que seria possível entender os seguintes elementos como expressão da tensividade: Andamento e Emissão (Timbre), de um lado; Articulação Rítmica e Vibrato, de outro.

Destacamos, ainda, que a Entoação, segundo o que observarmos, pode apresentar maior ou menor presença da fala e se mostrar regendo a interpretação de toda a obra ou, pontualmente, revelar um gesto local do intérprete. Desta forma, ela se articularia ora no campo global, ora no local, conforme identificamos no quadro abaixo. Assim, foi possível compreender se cada uma das vozes analisadas, segundo as articulações entre andamento, emissão, vibrato, articulação rítmica e entoação, apresentava-se regida predominantemente pela passionalização ou pela tematização, e, 
ainda, se esses regimes apresentariam índices de figurativização de acordo com a maior ou menor presença da fala no canto.

Chegamos a um desdobramento dos regimes propostos por Tatit, estendendo sua ação para a compreensão da orientação estética e interpretativa da voz.

Em nosso quadro analítico, denominamos essa orientação de Qualidade Emotiva, e a partir daí chegamos aos seguintes regimes, que consideram a figurativização como complementar aos dois regimes centrais, passionalização e tematização, que também podem se apresentar como complementar um do outro:

Passional: quando predominam as durações vocálicas, na maioria das vezes recobertas por algum tipo de vibrato, e a expansão pelo campo da tessitura com utilização de diversos sub-registros vocais;

Passional Figurativizada: quando aos valores da Passionalização soma-se a presença da fala, criando interjeições que reforçam a dramaticidade da interpretação;

Passional Tematizada: quando aos valores da Passionalização somam-se as reiterações motívicas, os ataques consonantais;

Tematizada: quando predominam as reiterações e os recortes rítmicos, com pouca expansão pelo campo da tessitura e utilização restrita dos sub-registros vocais;

Tematizada Passional: quando às reiterações e aos recortes rítmicos somamse a expansão pelo campo da tessitura e as durações vocálicas, contrapondo à percepção do percurso melódico as ações locais que revalorizam o plano global da interpretação;

Tematizada Figurativizada: quando soma-se a fala aos valores da Tematização. 


\subsubsection{Passionalização, tematização e figurativização vocais}

Ao transpormos para a voz os tipos de integração entre melodia e letra propostos por Tatit, pudemos concluir que cada tipo solicitava uma ação técnica particular do intérprete para que os valores inscritos na canção fossem revelados pela voz. Assim, segundo percebemos, uma voz em consonância com os elementos da passionalização desenvolve-se por uma extensão melódica ampla, faz uso de elementos de dinâmica na realização do fraseado e privilegia as durações em detrimento dos recortes rítmicos.

Essas durações, conforme observamos, poderiam aparecer revestidas por vibratos de diferentes tipos, respondendo aí a uma demanda estética em consonância com o gênero musical (samba-canção, valsa, seresta, sertanejo, bossa, pop, etc.), com o período da história da canção no qual o intérprete realizou a gravação ou mesmo com o perfil público já consagrado pelo intérprete.

Por exemplo, considerando as cantoras Araci Cortes e Carmen Miranda, que surgiram no mesmo período da história da canção brasileira, foi possível verificar que a presença de vibrato no canto se dava entre uma e outra de maneira bastante diferenciada. As canções analisadas neste trabalho - respectivamente, "Linda Flor" (gravada em 1929) e "Na Batucada da Vida" (gravada em 1934) - são regidas pela passionalização. A primeira, cantada por Araci Cortes, trata da questão da perda amorosa, enquanto a segunda, cantada por Carmen Miranda, embora retrate também uma história de disjunção amorosa, tem como tema principal os infortúnios da vida marginal do sujeito. Ambas as canções surgiram no contexto do teatro de revista e foram letradas por Luiz Peixoto. No entanto, as maneiras como as intérpretes se relacionam com os conteúdos disfóricos das canções são diversas entre si, e essa diversidade se reflete no canto de cada uma.

Pudemos observar que Carmen Miranda articulava sua voz com recursos muito próximos da fala e fazia uso de um vibrato lento bastante atenuado, presente 
nas notas longas, que geralmente incidiam sobre a penúltima sílaba das palavras. De certa forma, como apontamos na análise, isto se relacionava com o fato de a intérprete não desejar associar sua imagem aos conteúdos disfóricos expressos na letra, visto que nesse período ela já tinha uma imagem pública consolidada e associada a um permanente estado eufórico.

Araci Cortes, por sua vez, alternava entre uma emissão mais próxima à fala e a emissão mais cantada, na qual fazia uso de um vibrato rápido que se pronunciava sobre as notas longas, geralmente articuladas sobre a última sílaba das palavras. A ênfase nos prolongamentos ampliava a percepção do estado disfórico e, por consequência, do elemento passional que rege a composição. Araci Cortes, que foi uma clara influência para Carmen Miranda, ${ }^{28}$ tinha uma imagem pública associada ao teatro de revista, fato que, possivelmente, Ihe dava uma liberdade maior para exercitar a pluralidade dramática como cantora.

Daí seria possível concluirmos que a identidade vocal de Carmen Miranda era compatível com a qualidade emotiva que denominamos Tematização figurativizada, enquanto Araci Cortes poderia variar entre uma voz mais Passional e outra mais Tematizada, ainda que em ambas fosse possível detectar a presença da fala apontando a figurativização como elemento mediador tanto da passionalização, quanto da tematização vocal.

Da mesma forma, foi possível detectar que certas inflexões e ornamentações vocais, como apogiaturas, glissandos e portamentos, eram frequentemente utilizados por intérpretes cujas vozes apontavam índices elevados de passionalização e cuja formação vocal havia ocorrido antes da Bossa Nova.

\footnotetext{
${ }^{28}$ Nas gravações iniciais de Carmen Miranda, entre as quais se encontra Tai, eu fiz tudo pra você gostar de mim (1929), é perceptível essa influência, pois a cantora praticamente imita Araci Cortes nas articulações e no timbre. É importante destacar que em pouco tempo Carmen encontrou sua identidade vocal, libertando-se da influência inicial, sem contudo abandonar sua raiz musical, espelho de uma genealogia da voz.
} 
Pudemos constatar, ainda, que esses elementos estavam presentes de maneira acentuada nas vozes de Dalva de Oliveira e Orlando Silva, e mais atenuadamente nas vozes de Ciro Monteiro e Araci Cortes.

Detectamos, também, que intérpretes como Zezé di Camargo e Ana Carolina, mesmo tendo surgido após a Bossa Nova, não haviam sofrido nenhuma influência aparente desse movimento, sendo possível notar em seus cantos alguns componentes característicos do excesso dramático, como vibrato rápido, glissandos e portamentos, característicos de um canto mais passional. Ou seja, foi possível perceber que a maneira como esses cantores articulavam a passionalidade vocal estava, de certa forma, vinculada a uma referência firmada na canção brasileira pelo componente romântico, aliado a um exagero dramático bastante presente no período imediatamente anterior à Bossa Nova e, de certa forma, mantido por alguns cantores da Jovem Guarda. No caso de Ana Carolina, além desses elementos, é possível detectar nitidamente a influência da música pop norte-americana.

Seguindo nessa linha de raciocínio, pudemos averiguar que uma voz tematizada poderia percorrer ou não uma ampla extensão melódica. Mas a simplificação técnica da emissão, bem como a articulação rítmica, era o que a diferenciava fundamentalmente da voz passionalizada. Assim, a escuta desse tipo de voz poderia provocar uma percepção equivocada de simplicidade melódica, como ocorre com Carmen Miranda e Ná Ozzetti, por exemplo, porque são intérpretes que não enfatizam elementos que valorizam a percepção do percurso melódico e que inscrevem, em seus cantos, muitas inflexões de fala, caracterizando na voz um forte componente figurativo.

Por esse caminho, pudemos perceber que predominava nas vozes tematizadas a presença da articulação rítmica valorizando as ações locais, de forma a minimizar os espaços para os excessos melódicos ou para os trejeitos dramáticos.

Quanto à Figurativização - na qual o limite entre canto e fala é frequentemente rompido e o sujeito da enunciação marca presença viva pela voz do 
intérprete -, poderia aparecer como uma característica complementar tanto da voz Passional quanto da Tematizada.

Consideramos importante ilustrar com mais um exemplo extraído das análises, visto que a percepção do elemento figurativo na voz passional pode não ser tão claro quanto na voz tematizada. No entanto, se considerarmos a versão de Maria Bethânia para a canção "É o Amor", torna-se clara a percepção de que temos ali uma voz Passional, que valoriza as durações e a expressão dramática. No entanto, essa voz realiza esse movimento com um grau elevado de contenção, refreando o uso de vibrato e inserindo entoações quase faladas para caracterizar a proximidade entre enunciador e enunciatário. Com essa maneira de articular o canto, a voz materializa a existência do sujeito da narrativa, atualizando o discurso e conferindo corporeidade ao sujeito da enunciação.

Assim, como já afirmamos, detectamos que a Figurativização vocal tanto poderia recobrir as vozes passionais quanto as tematizadas. Ou seja, seria possível ao intérprete imprimir uma tal credibilidade no canto que 0 identificasse imediatamente com o enunciador/sujeito.

\subsubsection{Tensividade e construção de sentidos pela voz}

Por meio das análises, pudemos também perceber de que maneira os ajustes da voz e a escolha de determinados recursos poderiam configurar ações amplas ou pontuais para expressar os engates actanciais, as impressões imediatas, os estados fóricos (eufórico/disfórico) e os estados juntivos (conjunção/disjunção).

No que concerne ao timbre, dentro do corpus analisado, pudemos verificar que ocorria um predomínio da naturalidade da emissão. No entanto, nas gravações de Carmen Miranda, Araci Cortes e Gal Costa, foi possível observar uma manipulação do timbre não apenas para alterar a percepção do engate actancial, mas para exprimir uma impressão imediata e reforçar a dimensão intensa do canto - 
ou, no caso de Gal, para explorar uma outra musicalidade da voz, redimensionando o plano de expressão e o plano de conteúdo musicais.

O uso da extensão (tessitura) associado a uma transposição de registro vocal apareceu em Zezé di Camargo e Milton Nascimento. Nesses intérpretes, esse recurso vocal foi utilizado para exprimir os estados passionais e a disjunção extrema entre sujeito e objeto.

Já em Elis Regina, foi possível observar a expressão do estado passional justamente pela não transposição de registro vocal. Assim, a emissão de notas agudas em registro de peito produziu na audição a percepção de um estado de tensão revelador da condição disfórica e da disjunção vivenciada pelo sujeito/enunciador em "Na Batucada da Vida".

Da mesma forma, em "Beatriz", Ana Carolina se valeu de recurso similar ao produzir notas agudas em registro de peito. A tensão resultante conferiu à interpretação um componente de agressividade compatível com o gênero pop e também com a materialidade constituída pela interpretação, em oposição à gravação de Milton Nascimento, na qual toda a realização vocal condiz com os aspectos etéreos da narrativa.

Já nas gravações de "Ave Maria no Morro", por exemplo, pudemos verificar que os intérpretes, Dalva de Oliveira e João Gilberto, escolheram caminhos opostos para expressar a disforia. A primeira optou pela valorização do percurso melódico, fazendo uso da transposição de registro e também das durações alongadas como expressão do estado passional. João Gilberto, por sua vez, trabalhou a questão timbrística e o quase sussurro na emissão para revelar a disforia pelo caminho da intimidade, da dor não bradada que conserva o estado latente na contenção vocal.

Opção similar ocorreu, como já apontamos, com a regravação de "É o Amor" pela cantora Maria Bethânia. A escolha da tonalidade e a emissão contida conferem 
proximidade e ampliam o grau de intimidade entre enunciador e enunciatário. Também a articulação rítmica, característica da intérprete, somada à quase fala, redimensiona o projeto amplo da canção, reforçando a percepção de proximidade, de celebração íntima.

De modo geral, predominou nas gravações analisadas, entre a gravação original e a regravação, uma alteração de andamento sempre para menos. Ou seja, na maior parte dos casos, as regravações apresentam-se em andamentos mais lentos, reconfigurando, desta forma, o componente passional. No entanto, as regravações de "Beatriz" por Ana Carolina e do "Samba do Avião" por Gilberto Gil apresentaram um caminho inverso, visto que ambas foram realizadas em andamentos mais rápidos que as gravações originais.

Na regravação realizada por Ana Carolina, como já ressaltamos na análise, a mudança de gênero musical (de valsa para balada) acaba revelando outros conteúdos inscritos na composição. Tudo na interpretação conduz para o mundo real, e não mais para o universo onírico configurado na interpretação original. $O$ andamento acelerado, bem como o tipo de emissão vocal, confere materialidade ao discurso e acentua a presença de uma voz Passional tematizada. Ou seja, a todo instante a intérprete enfatiza os aspectos somáticos, revelando que a mudança no estado juntivo refere-se a um relacionamento real.

Já na regravação do "Samba do Avião" por Gilberto Gil, o andamento acelerado cuida de eliminar o componente passional presente originalmente na canção. A voz se tematiza para celebrar o estado conjunto que se realiza primeiro no plano visual para, em seguida, materializar-se no plano corporal. Assim, a ausência valorizada na gravação de Tom Jobim cede espaço para a presença e a conjunção celebradas na versão de Gilberto Gil. 


\subsection{QUADRO DESCRITIVO DAS VOZES}

A seguir, expomos o quadro descritivo das vozes. Destacamos a percepção de um plano global e um plano local, no qual se articulam as categorias demarcadas cuja resultante é a Qualidade Emotiva, expressa na última coluna do lado direito.

\begin{tabular}{|c|c|c|c|c|c|c|}
\hline & \multirow{2}{*}{\multicolumn{2}{|c|}{$\mathbf{G}$}} & \multicolumn{2}{|c|}{ O B } & $\mathbf{A}$ & \multirow{3}{*}{$\begin{array}{l}\text { L } \\
\text { Qualid. Emotiva }\end{array}$} \\
\hline & & & \multicolumn{3}{|c|}{$\begin{array}{lllll}\mathbf{L} & \mathbf{O} & \mathbf{C} & \mathbf{A} & \mathbf{L}\end{array}$} & \\
\hline & Andamento & Emissão & Art. Rit. & Entoação & Vibrato & \\
\hline Dalva de Oliveira & Médio & $\begin{array}{c}\text { Frontal } \\
\text { Metalizada }\end{array}$ & $\begin{array}{l}\text { Durações } \\
\text { Vocálicas }\end{array}$ & $\begin{array}{l}\text { Predom. } \\
\text { Cantada }\end{array}$ & $\begin{array}{l}\text { Intenso } \\
\text { Rápido }\end{array}$ & Passional \\
\hline João Gilberto & Lento & Mediana & $\begin{array}{c}\text { Ataques } \\
\text { Consonantais }\end{array}$ & $\begin{array}{c}\text { Alterna } \\
\text { Canto/Fala }\end{array}$ & Ausente & $\begin{array}{c}\text { Passional } \\
\text { Figurativizada }\end{array}$ \\
\hline Milton Nascimento & Lento & $\begin{array}{c}\text { Mediana } \\
\text { Anterioriz. }\end{array}$ & $\begin{array}{l}\text { Durações } \\
\text { Vocálicas }\end{array}$ & $\begin{array}{l}\text { Predom. } \\
\text { Cantada }\end{array}$ & $\begin{array}{c}\text { Atenuado } \\
\text { Lento } \\
\end{array}$ & $\begin{array}{c}\text { Passional } \\
\text { Figurativizada } \\
\end{array}$ \\
\hline Ana Carolina & Acelerado & Frontal & \begin{tabular}{|c|} 
Ataques \\
Consonantais \\
\end{tabular} & $\begin{array}{l}\text { Predom. } \\
\text { Cantada }\end{array}$ & $\begin{array}{l}\text { Intenso } \\
\text { Rápido }\end{array}$ & $\begin{array}{c}\text { Passional } \\
\text { Tematizada }\end{array}$ \\
\hline Zezé Di Camargo & Rápido & $\begin{array}{c}\text { Frontal } \\
\text { Metalizada }\end{array}$ & $\begin{array}{l}\text { Ataq.Cons. } \\
\text { Dur. Vocalic }\end{array}$ & $\begin{array}{l}\text { Predom } \\
\text { Cantada }\end{array}$ & $\begin{array}{l}\text { Intenso } \\
\text { Rápido }\end{array}$ & Passional \\
\hline Maria Bethânia & Lento & Frontal & $\begin{array}{l}\text { Dur.Vocalic } \\
\text { Ataq.Cons. }\end{array}$ & $\begin{array}{c}\text { Alterna } \\
\text { Canto/Fala } \\
\end{array}$ & Atenuado & $\begin{array}{c}\text { Passional } \\
\text { Figurativizada }\end{array}$ \\
\hline Cyro Monteiro & Rápido & Mediana & $\begin{array}{c}\text { Ataques } \\
\text { Consonantais }\end{array}$ & $\begin{array}{c}\text { Alterna } \\
\text { Canto/Fala }\end{array}$ & $\begin{array}{c}\text { Ausente } \\
\text { Atenuado }\end{array}$ & Tematizada \\
\hline Gal Costa & Acelerado & $\begin{array}{c}\text { Mediana } \\
\text { Anterioriz. }\end{array}$ & $\begin{array}{l}\text { Ataq. Cons. } \\
\text { Dur. Vocal. }\end{array}$ & $\begin{array}{l}\text { Predom. } \\
\text { Cantada }\end{array}$ & Ausente & $\begin{array}{c}\text { Tematizada } \\
\text { Passional }\end{array}$ \\
\hline Orlando Silva & Lento & Anterioriz. & $\begin{array}{l}\text { Durações } \\
\text { Vocálicas }\end{array}$ & $\begin{array}{l}\text { Predom } \\
\text { Cantada }\end{array}$ & Intenso & Passional \\
\hline Caetano Veloso & Lento & Mediana & $\begin{array}{l}\text { Durações } \\
\text { Vocálicas }\end{array}$ & $\begin{array}{l}\text { Predom } \\
\text { Cantada }\end{array}$ & $\begin{array}{l}\text { Intenso } \\
\text { finalizaç. }\end{array}$ & Passional \\
\hline Araci Cortes & Acelerado & $\begin{array}{c}\text { Frontal } \\
\text { Metalizad }\end{array}$ & $\begin{array}{l}\text { Ataq. Cons. } \\
\text { Dur. Vocal. }\end{array}$ & $\begin{array}{c}\text { Alterna } \\
\text { Canto/Fala }\end{array}$ & $\begin{array}{l}\text { Intenso } \\
\text { Rápido }\end{array}$ & $\begin{array}{c}\text { Tematizada } \\
\text { Passional }\end{array}$ \\
\hline Zezé Motta & Lento & Anterioriz. & $\begin{array}{l}\text { Durações } \\
\text { Vocálicas }\end{array}$ & $\begin{array}{l}\text { Predom. } \\
\text { Cantada }\end{array}$ & $\begin{array}{c}\text { Atenuado } \\
\text { Lento }\end{array}$ & $\begin{array}{c}\text { Passional } \\
\text { Tematizada }\end{array}$ \\
\hline Carmen Miranda & Rápido & Frontal & \begin{tabular}{|l|} 
Ataq. Conson. \\
Acent. Vocal.
\end{tabular} & $\begin{array}{c}\text { Predom. } \\
\text { Falada }\end{array}$ & Atenuado & $\begin{array}{c}\text { Tematizada } \\
\text { Figurativizada }\end{array}$ \\
\hline Elis Regina & Lento & Frontal & $\begin{array}{l}\text { Durações } \\
\text { Vocálicas }\end{array}$ & $\begin{array}{l}\text { Predom } \\
\text { Cantada }\end{array}$ & Atenuado & Passional \\
\hline Ná Ozzetti & Acelerado & Mediana & \begin{tabular}{|l|} 
Ataq. Conson. \\
Duraç. Vocal. \\
\end{tabular} & $\begin{array}{c}\text { Alterna } \\
\text { Canto/Fala } \\
\end{array}$ & $\begin{array}{c}\text { Atenuado } \\
\text { Rápido }\end{array}$ & $\begin{array}{c}\text { Tematizada } \\
\text { Passional }\end{array}$ \\
\hline Tom Jobim & Acelerado & Anterioriz. & $\begin{array}{l}\text { Durações } \\
\text { Vocálicas }\end{array}$ & $\begin{array}{l}\text { Predom } \\
\text { Cantada }\end{array}$ & Ausente & $\begin{array}{c}\text { Passional } \\
\text { Tematizada }\end{array}$ \\
\hline Gilberto Gil & Rápido & $\begin{array}{c}\text { Frontal } \\
\text { Anter. (voc) }\end{array}$ & $\begin{array}{l}\text { Ataq. Conson. } \\
\text { Acent. Vocal. }\end{array}$ & $\begin{array}{c}\text { Alterna } \\
\text { Canto/Fala }\end{array}$ & Ausente & Tematizada \\
\hline
\end{tabular}




\section{CONSIDERAÇÕES FINAIS}


Como dissemos logo no início deste trabalho, o canto popular no Brasil, apesar de sua expressiva relevância, somente há pouquíssimo tempo vem merecendo atenção de pesquisadores e conquistando espaço no ambiente acadêmico. Mesmo assim, ainda são poucas as pesquisas que abordam esse tipo de manifestação vocal e que propõem uma observação mais atenta desse ambiente de realização da voz.

Ao realizar este trabalho pretendemos contribuir, ainda que minimamente, para que esse espectro se amplie e que novos pesquisadores encontrem motivação para investigar esse assunto que nos é tão caro e tão representativo da nossa cultura.

Predominantemente os estudos sobre voz, reconhecidos em todo o mundo, concentram sua atenção na música erudita. Assim, muitas denominações e conclusões restringem-se à utilização da voz nesse tipo de ambiente musical.

Outros estudos sobre a música étnica, como o importante material coletado e analisado na obra Les Voix du Monde: une anthologie des expressions vocales (Musée De L'Homme,1996), trabalhando com comportamentos vocais bastante diversos, deu um passo importantíssimo no sentido de estabelecer uma nova terminologia para referir-se e mesmo analisar os comportamentos vocais.

Com a Semiótica da Canção, vislumbramos a possibilidade de dar início a um processo similar dentro do universo da canção brasileira. Essa prática descritiva desenvolvida por Luiz Tatit, dedicada a analisar o perfil melódico em consonância com a letra, pareceu-nos, desde o início, muito adequada à abordagem do gesto vocal, em consonância com a canção propriamente dita. Para tanto, seria necessário inserir o material referente à análise do comportamento vocal nos parâmetros estabelecidos pela Semiótica da Canção, encontrando as similaridades entre a descrição do perfil melódico e aquela pretendida para a descrição do perfil vocal.

Desta maneira, dedicamo-nos a observar quais realizações técnicas da voz se compatibilizariam com as manifestações dos estados fóricos e juntivos presentes na composição. Assim, pretendemos adotar uma prática descritiva que pudesse traduzir a intenção por trás do gesto interpretativo, ejetando da realização vocal a qualidade emotiva motriz dessa realização. 
Igualmente pretendemos estabelecer categorias para denominar os procedimentos da voz, demonstrando que as articulações internas realizadas (andamento, emissão [timbre], entoação, articulação rítmica e vibrato) seriam determinantes na construção de uma identidade vocal, que denominamos Qualidade Emotiva, que está descrita no quadro que finaliza o Capitulo 5 do presente trabalho. Essa Qualidade Emotiva seria compatível com os índices de Passionalização, Tematização e Figurativização estabelecidos por Tatit, que transpusemos para a voz como categorias: Passional, Passional Tematizada, Passional Figurativizada, Tematizada, Tematizada Passional e Tematizada Figurativizada.

Desta forma, buscamos compreender como a presença dos estados fóricos e juntivos se manifestava através da voz, pela articulação interna dos elementos da emissão, do timbre, do andamento, da entoação, do vibrato e da articulação rítmica, configurando ações na tensividade, perceptíveis nos diversos tipos de Qualidade Emotiva descritas acima.

Pudemos perceber também - felizmente, aliás - que há um lugar sagrado em cada realização que nenhuma análise é capaz de adentrar ou mesmo elucidar. Esse campo, no qual se articula a magia da realização artística e que torna impraticável uma ação puramente racional, talvez seja o que fascina e seduz os ouvintes de maneiras tão diversas e, por vezes, aparentemente inexplicáveis. Assim, para nos aproximarmos desse caminho, cabenos permitir que a emoção oriente a nossa trajetória... 
REFERÊNCIAS BIBLIOGRÁFICAS 


\section{BIBLIOGRAFIA}

BACHELARD, Gaston. O ar e os sonhos. São Paulo. Martins Fontes, 2009.

BARROS, Diana Luz P. de. Teoria do discurso: fundamentos semióticos. São Paulo: FFLCH/USP, 2002.

. Teoria semiótica do texto. São Paulo: Ática, 2008.

BARTHES, Roland. A escuta. In: ___ O óbvio e o obtuso. Rio de Janeiro: Nova Fronteira, 1990. cap. 2, p. 217-235.

. O grão da voz. In: . O óbvio e o obtuso. Rio de Janeiro: Nova Fronteira, 1990. cap. 2, p.237-245.

. A música, a voz, a língua. In: . O óbvio e o obtuso. Rio de Janeiro:

Nova Fronteira, 1990. cap. 2, p. 247-252. . A aventura semiológica. São Paulo: Martins Fontes, 2001.

BEHLAU, Mara; REHDER, Maria Inês. Higiene vocal para o canto coral. São Paulo: Revinter, 1997.

CABRAL, Sergio. No tempo de Ari Barroso. Rio de Janeiro: Lumiar, 1993.

CAMPOS, Augusto. Balanço da bossa e outras bossas. São Paulo: Perspectiva. 1978.

CARMO JR., José Roberto do. Da voz aos instrumentos musicais: um estudo semiótico. São Paulo: Annablume/Fapesp, 2005.

CASTRO, Ruy. Chega de saudade: a história e as histórias da Bossa Nova. São Paulo: Companhia das Letras, 2008. 
COELHO, Márcio Luiz Gusmão. O arranjo como elemento orgânico ligado à canção popular brasileira: uma proposta de análise semiótica. São Paulo, 2007. Tese (Doutorado em Semiótica e Linguística Geral) - Universidade de São Paulo.

DIETRICH, Peter. Semiótica do discurso musical: uma discussão a partir das canções de Chico Buarque. São Paulo, 2008. Tese (Doutorado em Semiótica e Linguística Geral) - Universidade de São Paulo.

. Araçá azul: uma análise semiótica. São Paulo, 2003. Dissertação (Mestrado em Semiótica e Linguística Geral) - Universidade de São Paulo.

DINIZ, Julio. Sentimental demais: a voz como rasura. In: DUARTE, P. S.; NAVES, S. C. (orgs.). Do samba-canção à Tropicália. Rio de Janeiro: Faperj/Relume-Dumará, 2003.

DINIZ, Maria Lúcia Vissotto Paiva. Práxis enunciativa no telejornal: tensividade em notícia. Estudos Semióticos, São Paulo, n. 2, 2006. Disponível em http://www.fflch.usp.br/dl/semiotica/es/eSSe2/2006-eSSe2-M.L.V.P.DINIZ.pdf. Acesso em março de 2012.

DOURADO, Henrique A. Dicionário de termos e expressões da música. São Paulo: Editora 34,2008

EL HAOULI, Janete. Demetrio Stratos: em busca da voz-música. Londrina: Edição Independente, 2002.

FAVARETTO, Celso. Tropicália alegoria, alegria. São Paulo: Ateliê Editorial, 1996.

FIORIN, José Luiz. Em busca do sentido: estudos discursivos. São Paulo: Contexto, 2008.

FONTANILLE, Jacques; ZILBERBERG, Claude. Tensão e significação. São Paulo: Discurso Editorial/Humanitas/FFLCH-USP, 2001.

GARCIA, Walter. Bim Bom: a contradição sem conflitos de João Gilberto. São Paulo: Paz e Terra, 1999. 
GREIMAS, Algiras Julien. Da imperfeição. São Paulo: Hacker, 2002.

GREIMAS, Algiras Julien; COURTÉS, Joseph. Dicionário de Semiótica. São Paulo: Cultrix, 1979.

HOUAISS, Antonio. Dicionário Eletrônico Houaiss da Língua Portuguesa. Rio de Janeiro: Objetiva, 2001.

LOPES, Ivan C.; HERNANDES, Nilton (Org.). Semiótica: objetos e práticas. São Paulo: Contexto, 2005.

MACHADO, Regina. A voz na canção popular brasileira: um estudo sobre a Vanguarda Paulista. São Paulo: Ateliê Editorial, 2011.

MAMMI, Lorenzo; NESTROVSKI, Arthur; TATIT, Luiz. Três canções de Tom Jobim. São Paulo: Cosac Naify, 2004.

MATOS, Claudia N.; TRAVASSOS, Elizabeth; MEDEIROS, Fernanda T. Palavra cantada: ensaios sobre poesia, música e voz. Rio de Janeiro: 7Letras/Faperj, 2008.

MEDEIROS, Beatriz Raposo de. Pistas de competência cancional na entoação da canção. Cognição \& Artes Musicais/ Cognition\& Musical Arts, v. 4, n.1, PP. 5-11, 2009.

MELLO, Zuza Homem de; SEVERIANO, Jairo. A canção no tempo: 85 anos de música brasileira. São Paulo: Editora 34, 1997. v. 1 e 2.

MILLER, Richard. The Structure of Singing. New York: Schirmer Books, 1986.

MILLER, Richard. La structure du chant: pédagogie systématique de l'art du chant. Paris: Cité de La Musique, Centre de Ressources de Musique er Danse, 1996.

NAPOLITANO, Marcos. Seguindo a canção: engajamento político e indústria cultural na MPB (1959-1969). São Paulo: Annablume/Fapesp, 2001. 106 p.

NESTROVSKI, Arthur (Org.). Lendo música: 10 ensaios sobre 10 canções. São Paulo: Publifolha, 2007. 
OCHOA, Ana Maria e ULHOA, Marta. (org.). Pontos de escuta: música popular na América Latina. Porto Alegre. Editora UFRGS, 2005.

PACHECO, Claudia de O. L.; MARÇAL, Márcia. Registro e cobertura: investigações teóricas e práticas. São Paulo: Cefac, 2001.

RUIZ, Roberto. Araci Cortes, linda flor. Rio de janeiro, Funarte, 1984.

SANDRONI, Carlos. Feitiço decente: transformações do samba no Rio de Janeiro (1917-1933). Rio de Janeiro: Jorge Zahar, 2001.

SAUSURRE, Ferdinand de. Curso de Lingüística Geral. São Paulo: Cultrix.2010

TATIT, Luiz. A canção: eficácia e encanto. São Paulo: Atual, 1986.

. Semiótica da canção: melodia e letra. São Paulo: Escuta, 1994.

. O cancionista: composição de canções no Brasil. São Paulo: Edusp, 1995.

. Musicando a semiótica: ensaios. São Paulo: Annablume/Fapesp, 1997.

. Análise semiótica através das letras. São Paulo: Ateliê Editorial, 2002. 107 p.

. O século da canção. São Paulo: Ateliê Editorial, 2004.

. A abordagem do texto. In: FIORIN, José Luiz (org.). Introdução à lingüística.

V. I. São Paulo: Contexto, 2005.

. Semiótica à luz de Guimarães Rosa. São Paulo: Ateliê Editorial, 2010.

TATIT, Luiz; LOPES, Ivan C. Elos de melodia e letra: análise semiótica de seis canções. São Paulo: Ateliê Editorial, 2008.

VALÉRY, Paul. Variedades. São Paulo: lluminuras, 2007.

WISNIK, José Miguel. Sem receita: ensaios e canções. São Paulo: Publifolha, 2004. 
ZAN, José Roberto. A sonoridade da banda Black Rio. Disponível em http://www.nics.unicamp.br/muspop/Musica_Popular/Publicacoes_files/robertoz an.pdf. Acesso em março de 2012.

ZILBERBERG, Claude. Razão e poética do sentido. São Paulo: Edusp, 2006.

ZUMTHOR, Paul. Performance, recepção, leitura. São Paulo: Educ, 2000. . Escritura e nomadismo. São Paulo: Ateliê Editorial, 2005.

\section{DISCOGRAFIA}

ANA CAROLINA. Beatriz, BMG, 1999.

CAMARGO, Zezé di \& LUCIANO. É o amor, Rio de Janeiro: Copacabana Sony/BMG, $1991 / 2005$.

CORTES, Araci. laiá (Linda flor), Rio de Janeiro: Funarte, [1929] 1984.

COSTA, Gal. Falsa baiana, Rio de Janeiro: Phonogram/Philips, 1971.

ELIS REGINA. Na batucada da vida, Rio de Janeiro: CBD-Phonogram/Philips, 1974.

GIL, Gilberto. Samba do avião, Rio de Janeiro: WEA, 1977.

JOÃO GILBERTO. Ave Maria no morro, Rio de Janeiro: Polygram/Philips, 1991.

JOBIM, Tom. Samba do avião, USA: Discovery, 1965.

MARIA BETHÂNIA. É o amor, São Paulo: BMG, 1999.

MIRANDA, Carmen, Na batucada da vida, São Paulo: Revivendo Discos, [1934] s.d.

MONTEIRO, Ciro. Falsa baiana, São Paulo: Revivendo Discos, [1944] s.d. 
MOTTA, Zezé. Yayá (Linda flor), Rio de Janeiro: Warner, 1979

NASCIMENTO, Milton. Beatriz, Rio de Janeiro, Som Livre, 1983.

OLIVEIRA, Dalva de. Ave Maria no morro, São Paulo, Revivendo Discos, [1942] s.d.

OZZETTI, Ná. Na batucada da vida, São Paulo: MCD, 2009.

SILVA, Orlando. Lábios que eu beijei, Rio de Janeiro: Victor, 1937.

VELOSO, Caetano. Lábios que eu beijei, Rio de Janeiro: Polygram/Philips, 1995. 
A NEXO 


\title{
ANEXO 1
}

\section{DISCOS CONTENDO AS FAIXAS ANALISADAS}

\author{
"Ave Maria no Morro" \\ (Herivelto Martins)
}

\section{Intérprete: Dalva de Oliveira (Trio de Ouro)}

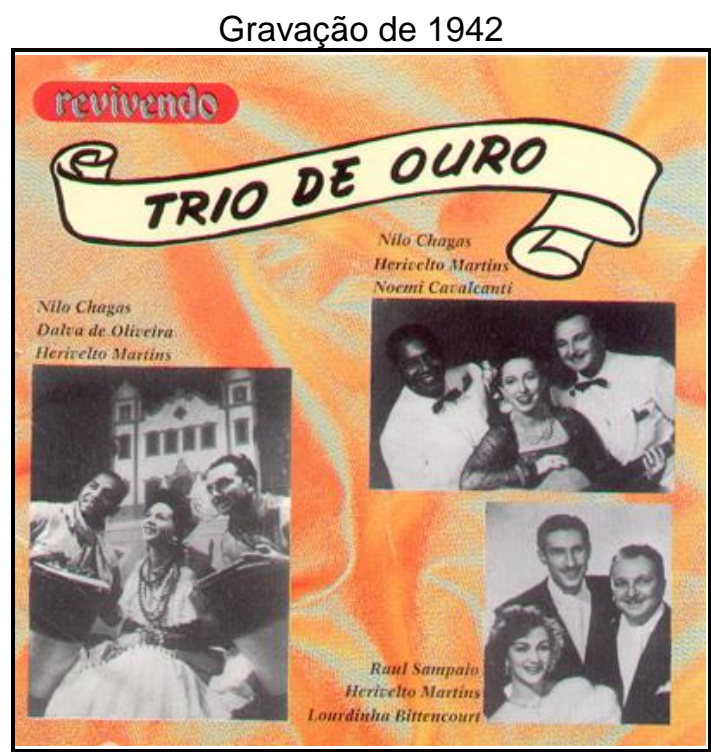

TRIO DE OURO

Gravadora: Revivendo Discos

Produtor: Leon Barg

Formato: $\quad \mathrm{CD} / 0$

Observação: Coletânea que abrange as três fases do Trio de Ouro, as duas últimas sem Dalva de Oliveira.

\footnotetext{
Faixa 1: $\quad$ Ave Maria no Morro (1942)

Músico(s): Dalva de Oliveira: Voz; Herivelto Martins: Voz; Nilo Chagas: Voz. Fon-Fon (Otaviano Romero Monteiro) e sua Orquestra
} 


\section{Intérprete: João Gilberto}

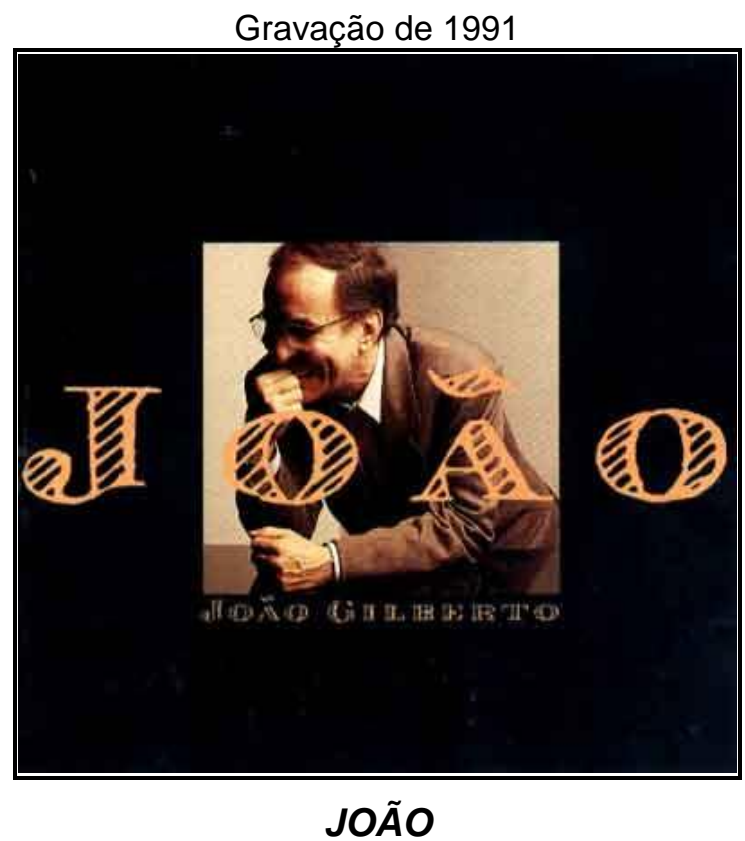

Gravadora: Polygram/Philips

Produtores: Mayrton Bahia/ Carmela Forsin

Formatos: $\quad$ CD/1991; LP/1991

Observação: Orquestra americana sob a regência de Clare Fischer

Faixa 9: $\quad$ Ave Maria no Morro

Arranjador: Clare Fischer 


\section{"Beatriz"}

(Edu Lobo e Chico Buarque de Holanda)

\section{Intérprete: Milton Nascimento}

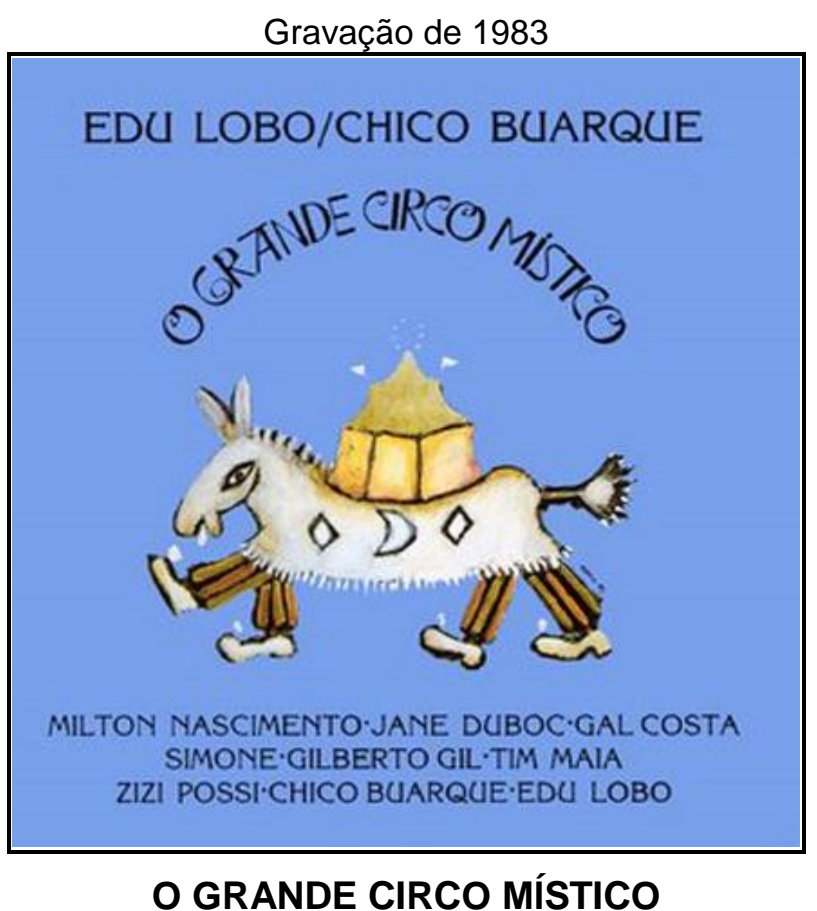

Gravadora: Som Livre (LP) /

LoboMarola (CD-2002)

Produtores: Edu Lobo/ Homero Ferreira

Formatos: $\quad$ LP/1983, CD/2002

Observações: Edu Lobo, Chico Buarque, Diversos intérpretes

Faixa 2: $\quad$ Beatriz

Arranjadores: Chiquinho de Moraes e Edu Lobo 


\section{Intérprete: Ana Carolina}

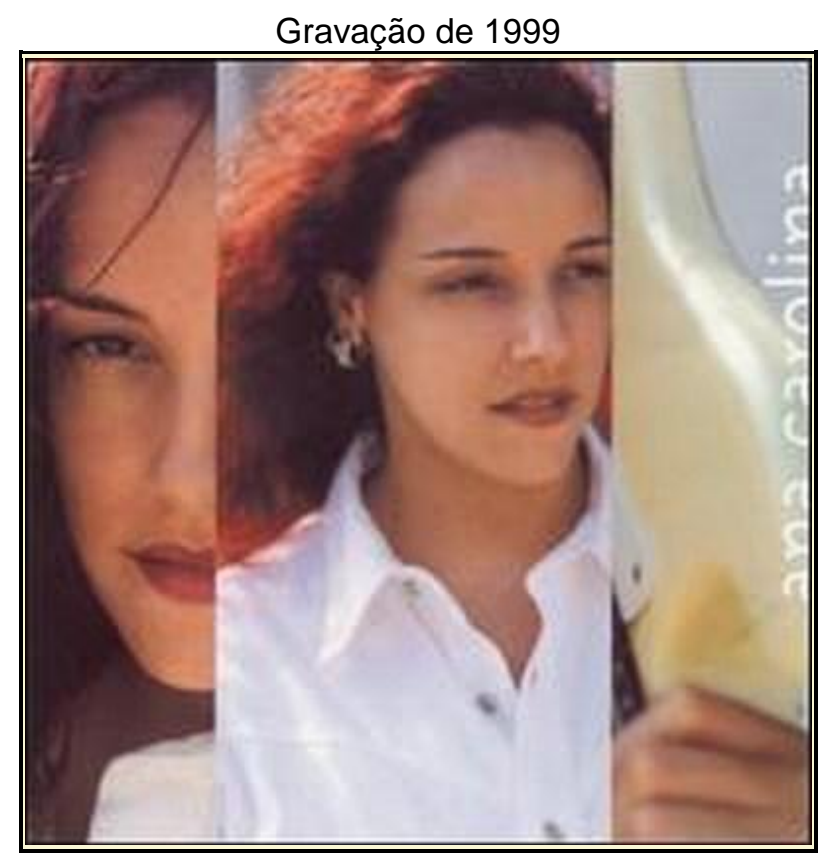

ANA CAROLINA

Gravadora: BMG

Produtor: Nilo Romero

Formato: $\quad \mathrm{CD} / 1999$

Faixa 14: Beatriz

Músicos: $\quad$ Ana Carolina: Violão; Paulinho Moska: Violão de aço.

Arranjadora: Ana Carolina 


\author{
"É o Amor" \\ (Zezé di Camargo)
}

\title{
Intérprete: Zezé di Camargo e Luciano
}

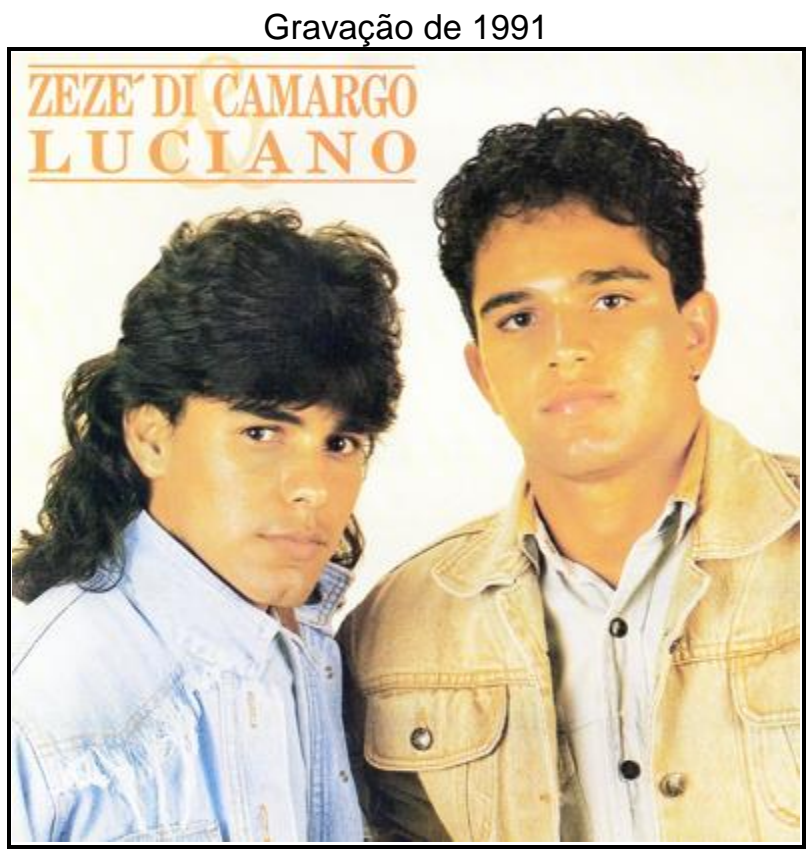

ZEZÉ DI CAMARGO \& LUCIANO

Gravadora: Copacabana/Sony/BMG

Produtor: $\quad$ Som Indústria e Comércio S.A

Formatos: $\quad$ LP/1991 e CD/2005

Faixa 1: É o Amor 
Intérprete: Maria Bethânia

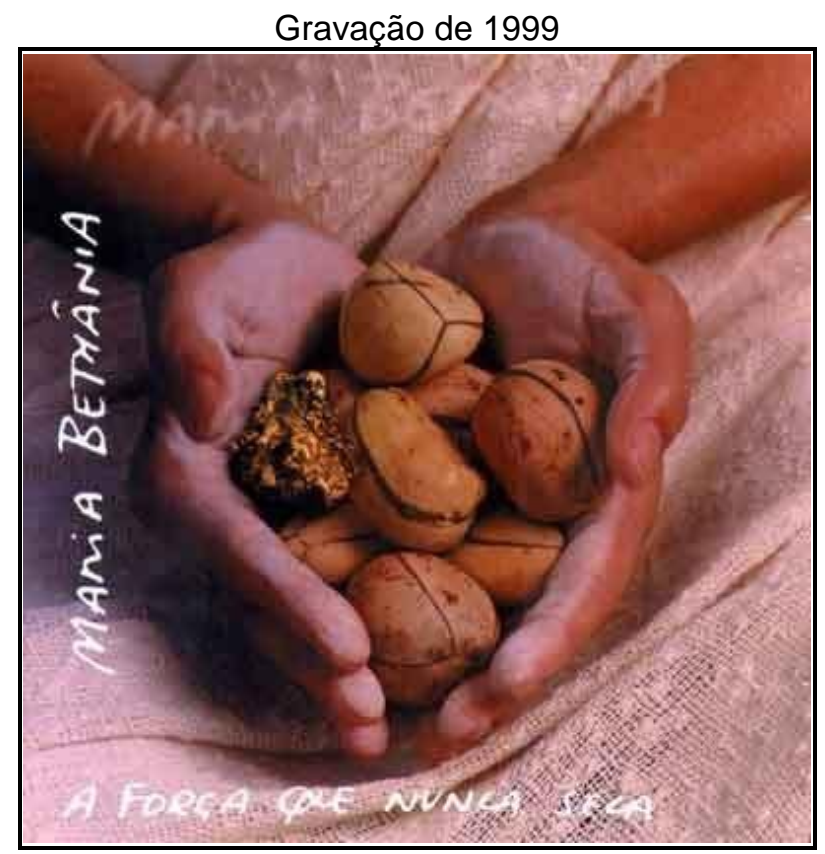

A FORÇA QUE NUNCA SECA

Gravadora: BMG

Produtores: Guto Graça Mello/ Moogie Canázio

Formato: $\quad C D / 1999$

Faixa 3: É $\quad$ Amor

Arranjadores: Graham Preskett / João Carlos

Coutinho 


\title{
"Falsa Baiana"
}

(Geraldo Pereira)

\section{Intérprete: Ciro Monteiro}

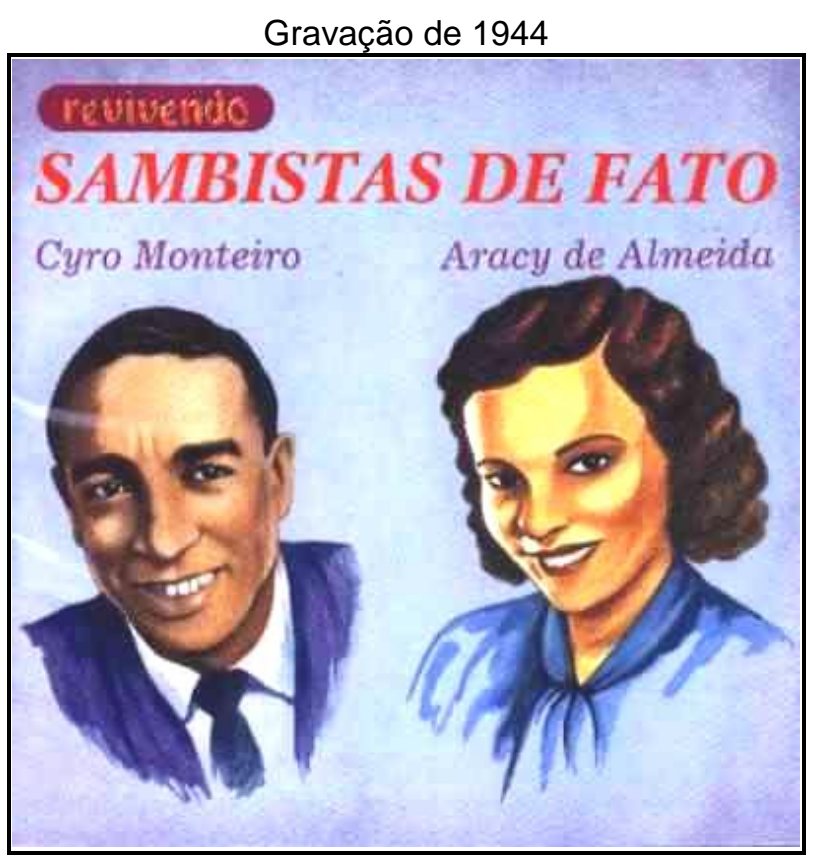

SAMBISTAS DE FATO: Cyro Monteiro / Aracy de Almeida/

\author{
Gravadora: Revivendo Discos/ EMI/ RCA \\ Produtor: Leon Barg \\ Formato: $\quad \mathrm{CD} / 0$
}

Faixa 1: $\quad$ Falsa Baiana

Músico(s): Benedito Lacerda e seu Regional 
Intérprete: Gal Costa

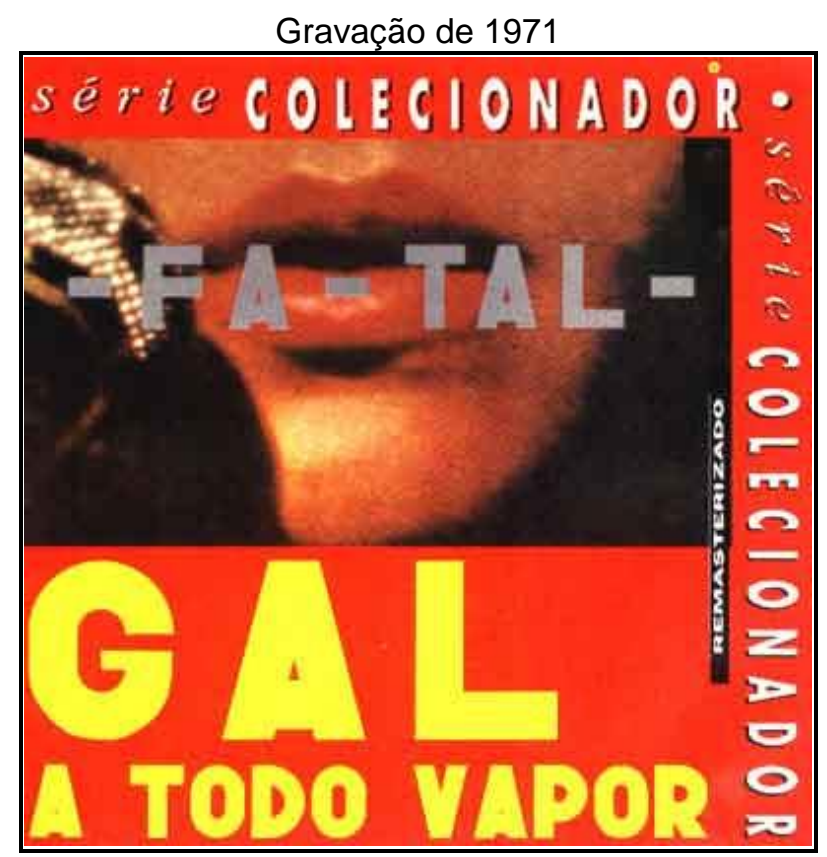

FA-TAL GAL A TODO VAPOR

$\begin{array}{ll}\text { Gravadora: } & \text { Phonogram/Philips } \\ \text { Produtor: } & \text { Roberto Menescal } \\ \text { Formatos: } & \text { LP/1971, CD/1993 } \\ \text { Faixa 15: } & \text { Falsa Baiana } \\ \text { Músico: } & \text { Gal Costa: violão } \\ \text { Arranjador: } & \text { Lanny Gordin }\end{array}$




\section{"Lábios que beijei"}

(J. Cascata e Leonel Azevedo)

\section{Intérprete: Orlando Silva}

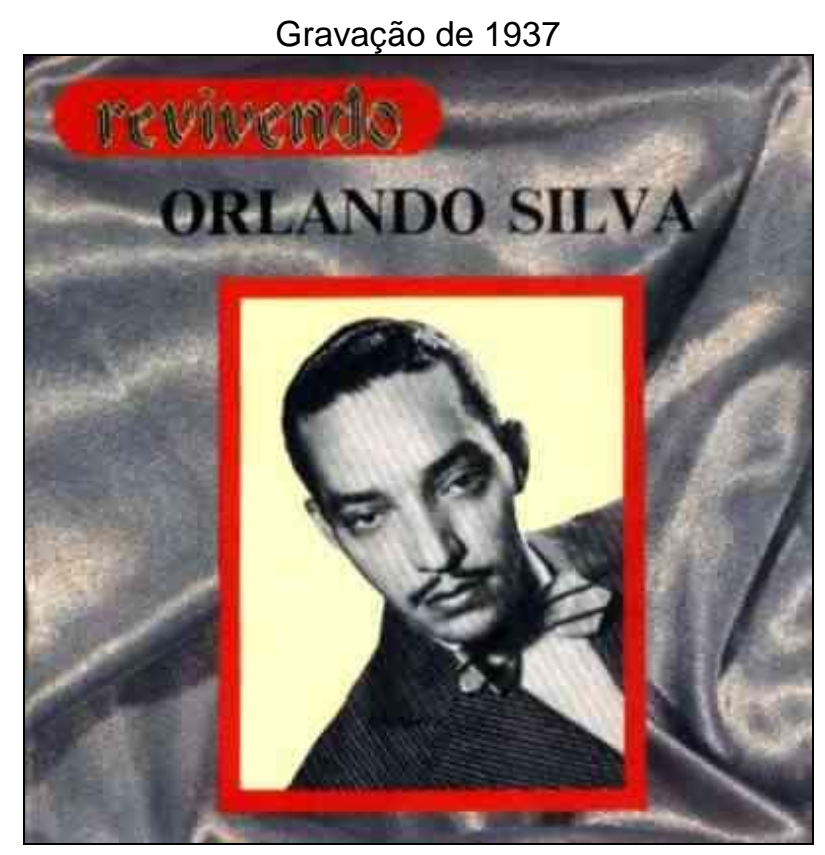

Gravadora: Victor

Rotação: $\quad 78$ (original)

Faixa 8: $\quad$ Lábios que Beijei

Arranjador: $\quad$ Radamés Gnatalli

Instrumentação: Orquestra Victor Brasileira

Observação: $\quad$ Faixa 8 do CD Revivendo Orlando silva, de 
Intérprete: Caetano Veloso

Gravação de 1995

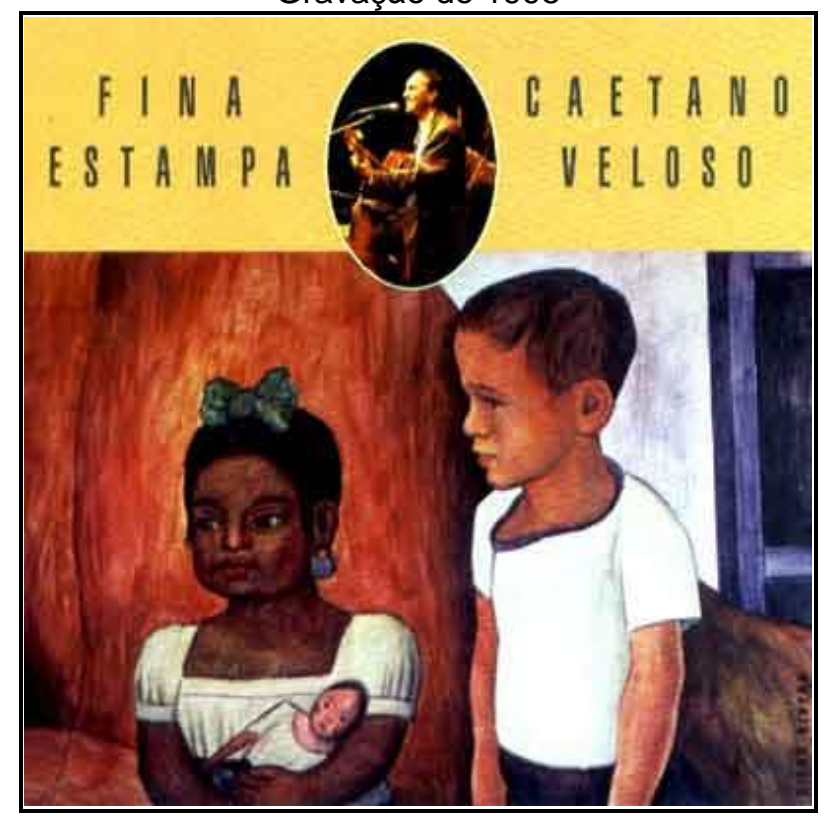

FINA ESTAMPA AO VIVO

Gravadora: Polygram/Philips

Produtor: Jaques Morelenbaum

Formato: $\quad$ CD/1995

Faixa 8: $\quad$ Lábios que Beijei

Arranjador: Jaques Morelenbaum 


\section{"Linda Flor (Yayá)"}

(Henrique Vogeler, Marques Porto e Luiz Peixoto)

\section{Intérprete: Araci Cortes}

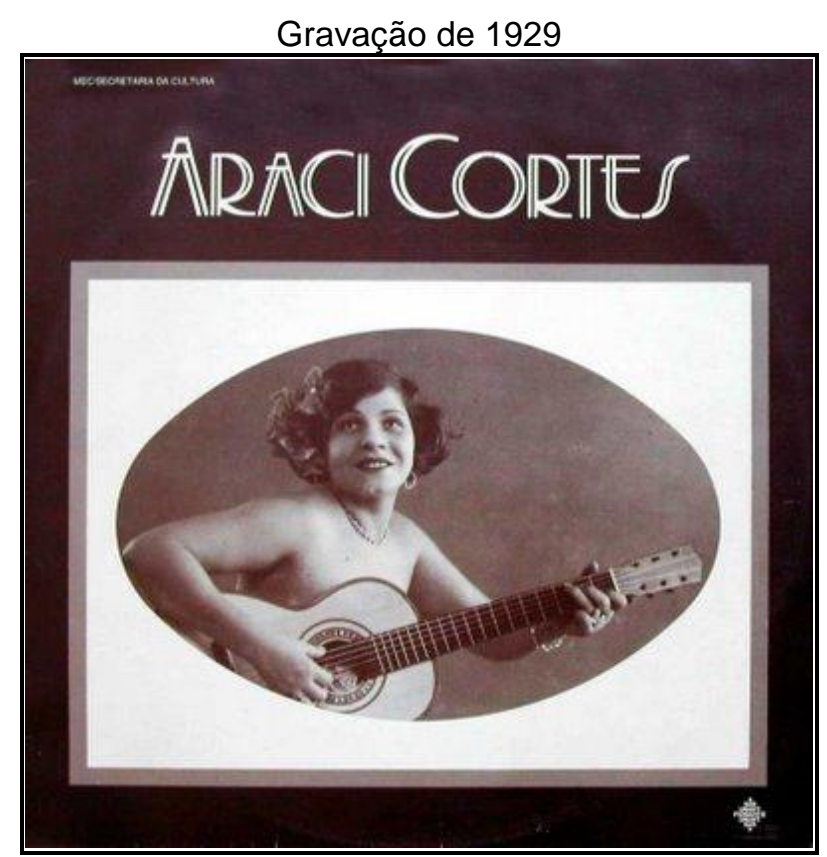

ARACI CORTES

Gravadora: Prensagem: Gravações Elétricas S.A.

Produtor: Produção artística e pesquisa: Jairo Severiano

Formato:

LP

Observação: Fonograma original inserido no discodocumento sobre sua carreira, lançado em 1984 pela Funarte, pelo Projeto Almirante, que recolhe alguns fonogramas da cantora Araci Cortes e procura resgatar alguns de seus maiores sucessos em gravações originais.

laiá (Linda Flor) foi lançada em março de 1929 com a Orquestra Parlophon

Produção fonográfica: Funarte / INM / Divisão de Música Popular

Produção executiva: Julia Peregrino

Faixa 2-A: $\quad$ laiá (Linda Flor) 
Intérprete: Zezé Motta

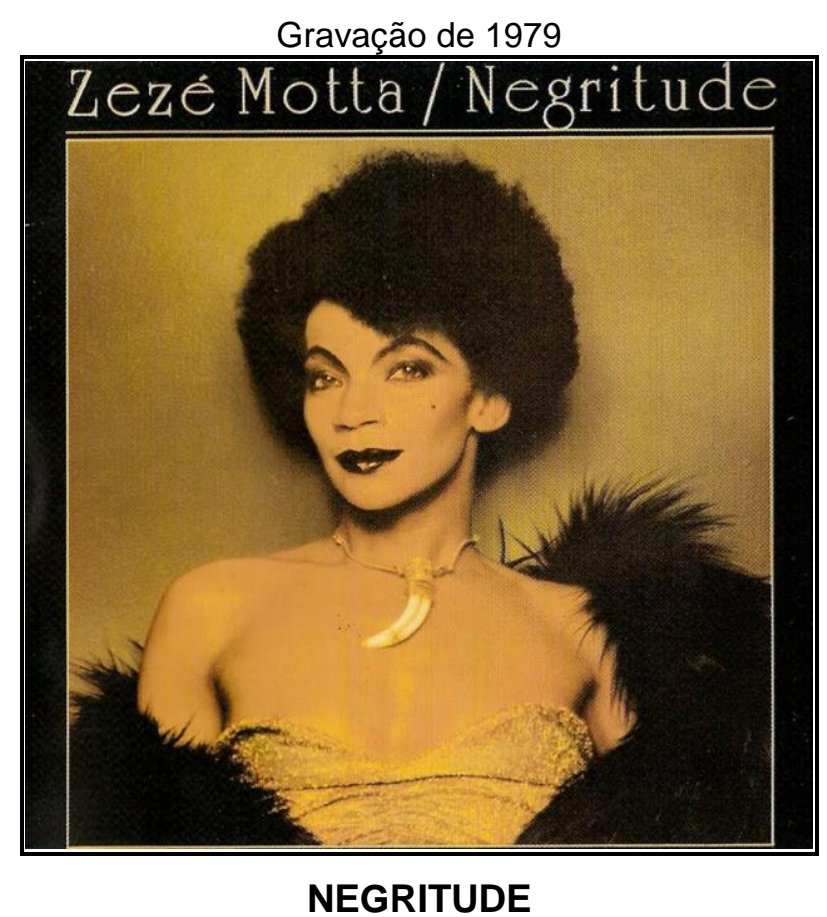

Gravadora: Warner

Produtor: João de Aquino

Formatos: LP/CD

Faixa 5-B Yayá 
"Na Batucada da Vida"

(Ary Barroso e Luiz Peixoto)

Intérprete: Carmen Miranda

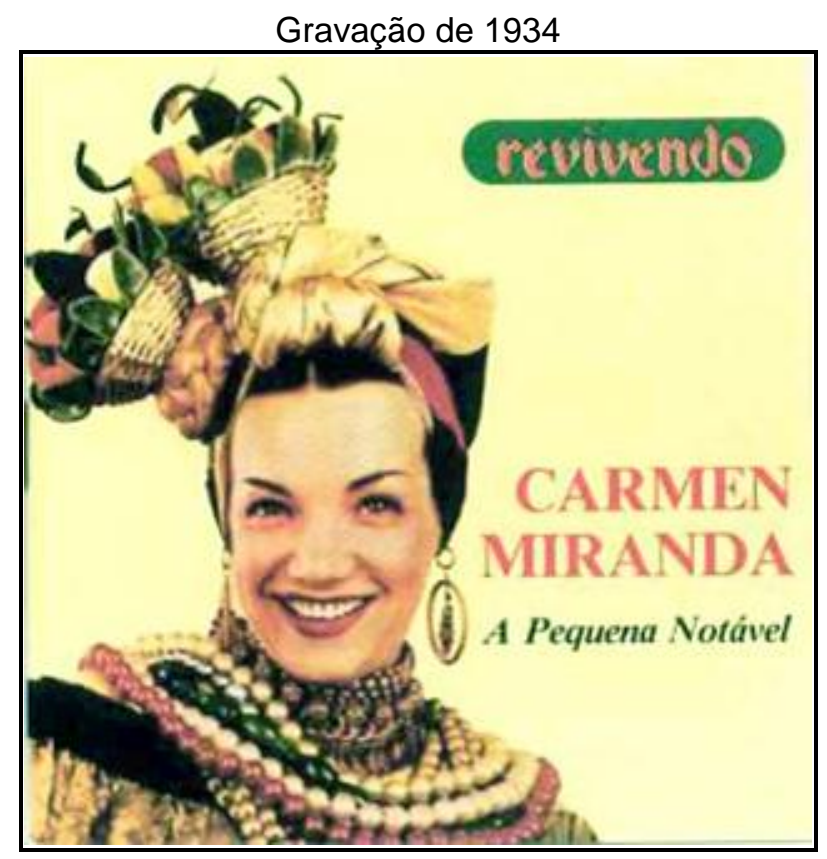

A PEQUENA NOTÁVEL

Gravadora: Revivendo Discos

Produtor: Leon Barg

Formato: $\quad \mathrm{CD} / 0$

Observação: Coletânea. RVCD 037, sem o ano de lançamento.

Faixa 14: $\quad$ Na Batucada da Vida (1934)

Músicos: Diabos do Céu 
Intérprete: Elis Regina

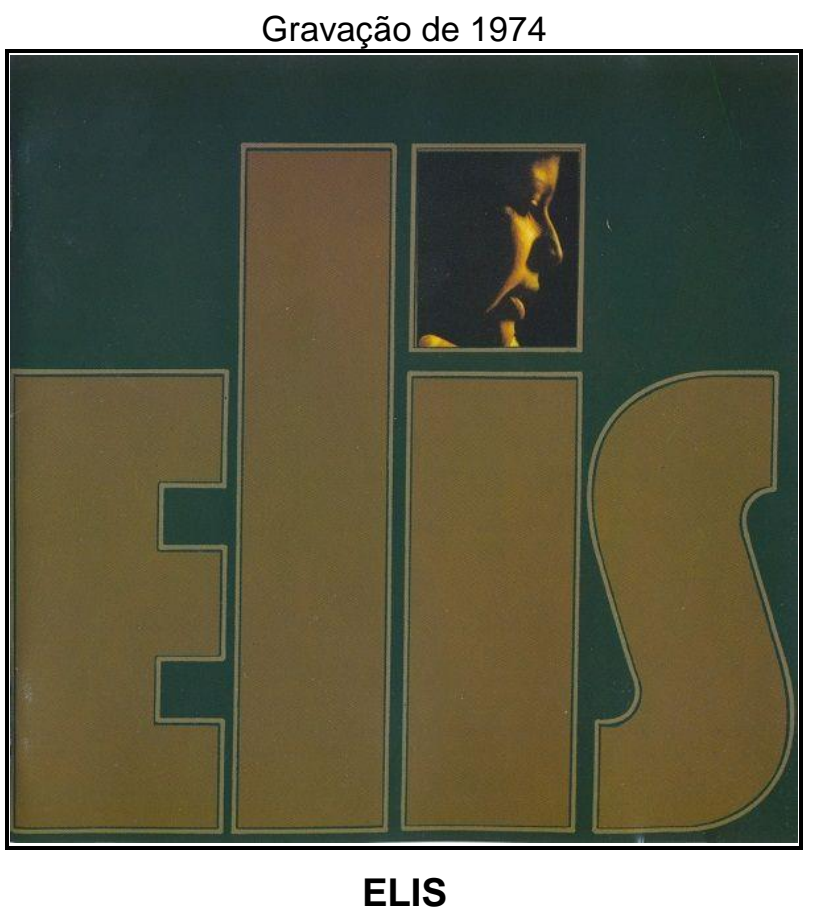

Gravadora: CBD-Phonogram/Philips

Produtor: Mazola

Formatos: $\quad$ LP/1974, CD/1993, CD/1998

Faixa 1: $\quad$ Na Batucada da Vida

Arranjador: Cesar Camargo Mariano 
Intérprete: Ná Ozzetti

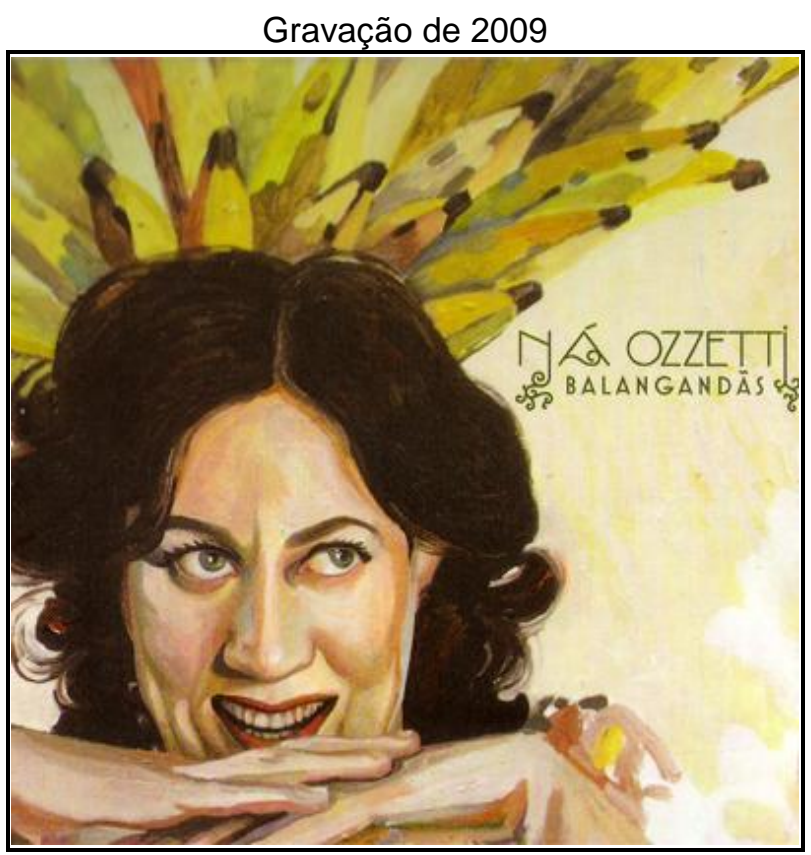

BALANGANDÃS

Gravadora: $\quad$ MCD

Produtores: Ná Ozzetti/ Dante Ozzetti/ Mário Manga/ Sérgio Reze/ Zé A.

Carvalho/ Alberto Ranellucci

Formato: $\quad$ CD/2009

Faixa 8: $\quad$ Na Batucada da Vida

Arranjador(es): Dante Ozzetti/ Mário Manga/

Sérgio Reze/ Zé Alexandre

Carvalho 


\section{"Samba do Avião"}

(Tom Jobim)

Intérprete: Tom Jobim

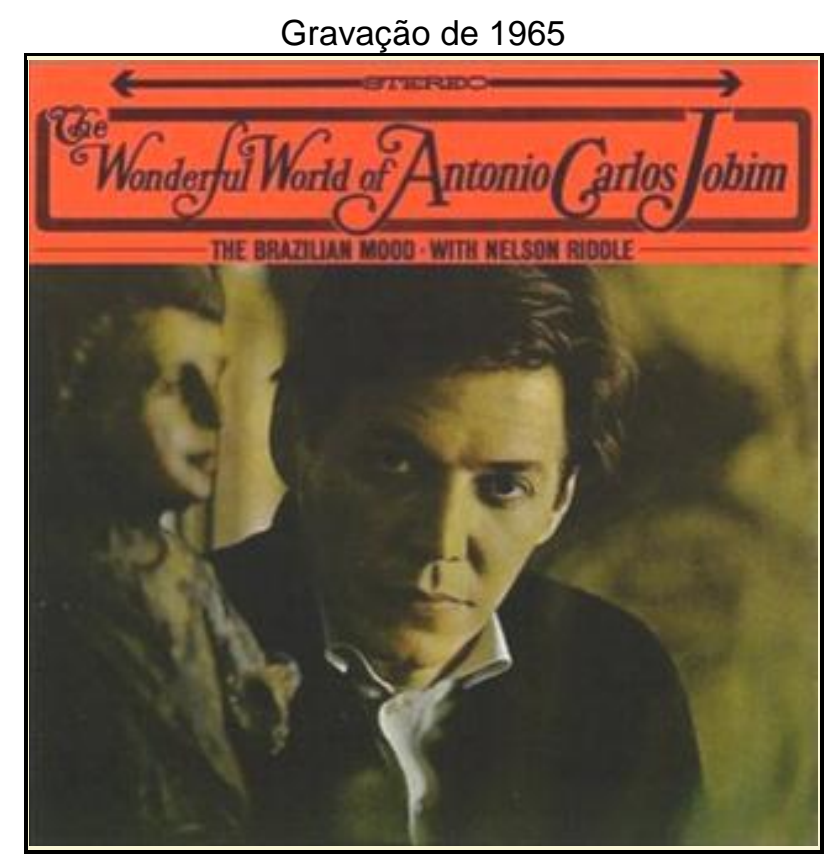

THE WONDERFUL WORLD OF ANTONIO CARLOS JOBIM
Gravadora: Discovery
Produtor: Jimmy Hilliard
Formatos: $\quad$ LP/1967, CD/1986
Faixa 10 Samba do Avião
Arranjador: Nelson Riddle 


\section{Intérprete: Gilberto Gil}

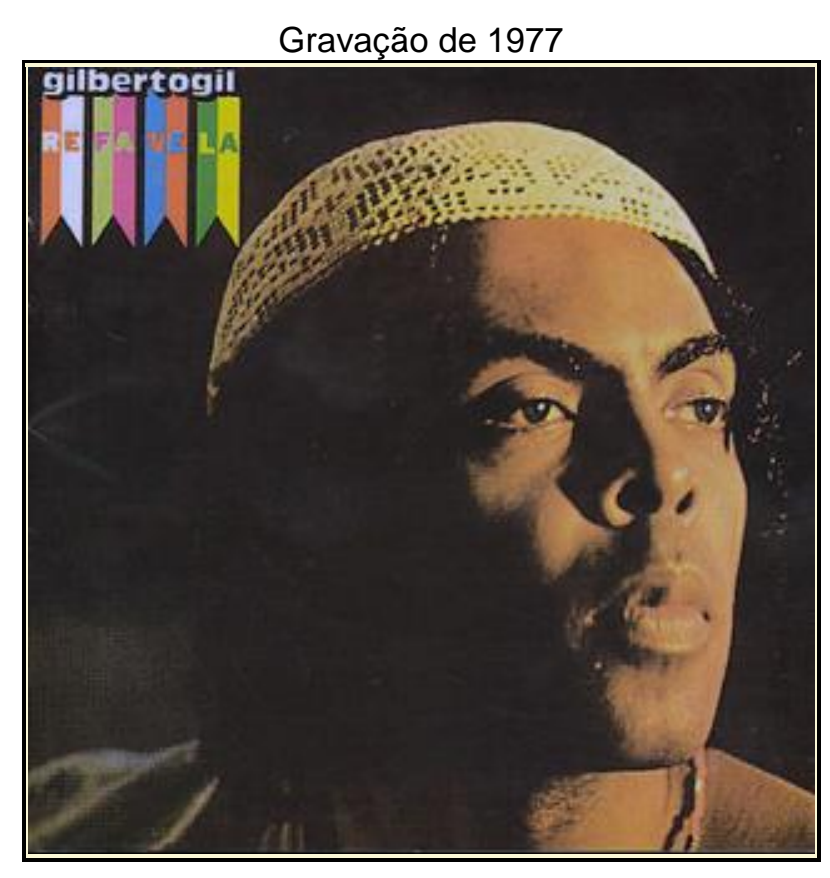

REFAVELA

Gravadora: WEA

Produtor: Roberto Santana

Formatos: $\quad$ LP/1977, CD/1994

Faixa 7: $\quad$ Samba do Avião

Arranjador(es): Gilberto Gil / J. T. Meirelles 